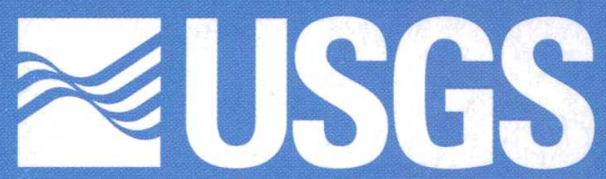

\title{
Simulation of Ground-Water Discharge to Biscayne Bay, Southeastern Florida
}

pecel

\section{U.S. DEPARTMENT OF THE INTERIOR}

U.S. GEOLOGICAL SURVEY

Prepared as part of the

U.S. GEOLOGICAL SURVEY PLACE-BASED STUDIES PROGRAM and in cooperation with the

U.S. ARMY CORPS OF ENGINEERS

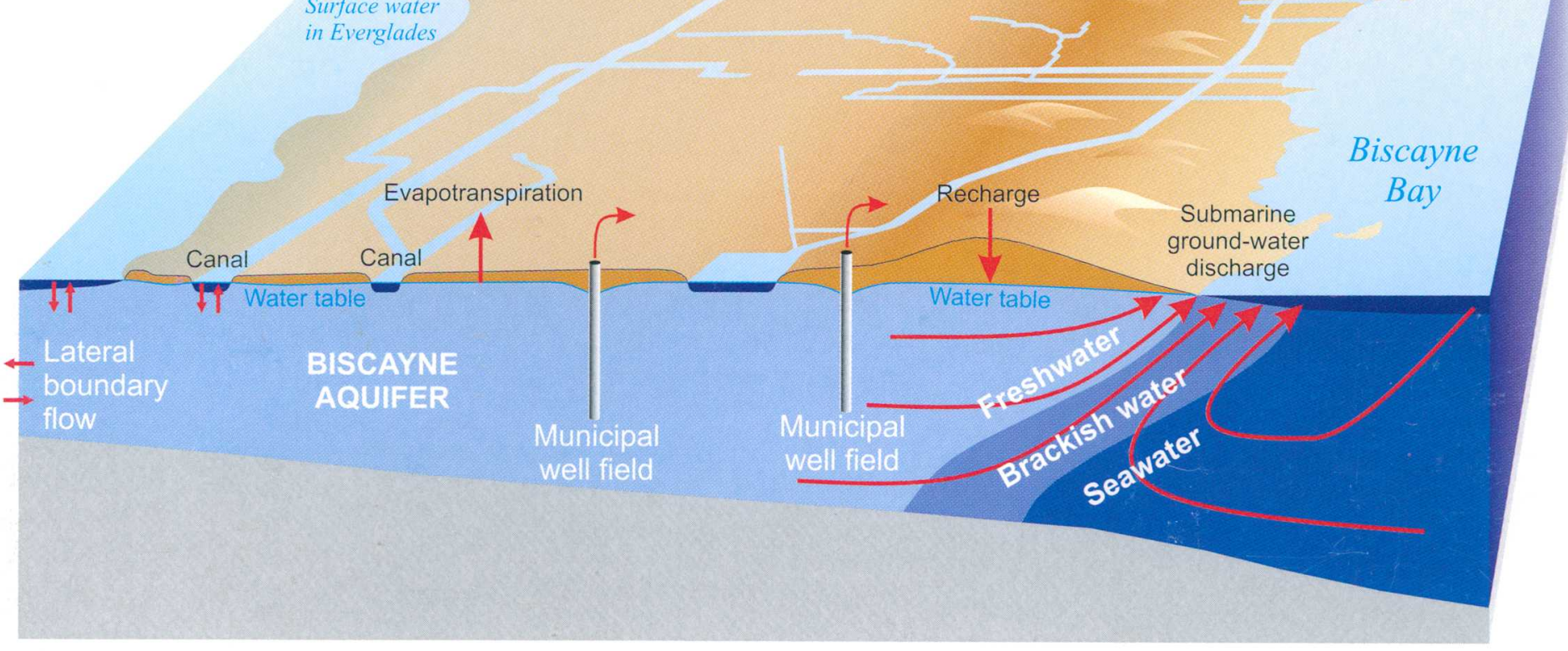




\section{Cecuigl \\ Information Requested for Products Received $/ /-5-0 /$ Branch of Information Services Denver, Colorado}

\section{Send this information by email to wrir@mailcapp.er.usgs.gov}

Report Number: WRIR 00-4251

Report Name: Simulation of Ground-Water Discharge to Biscayne Bay, Southeastern Florida

Short Title (limit to 30 characters): GW Discharge Biscayne Bay, FL

Author: Langevin, C.D.

Price: $\$ 4.00$

Number of copies to BIS: 44

Number of Pages: 127

Number of Plates: 3

Diskettes or CD-ROM:

What product this supersedes, if any:

Who is the contact for reprints if BIS runs out: USGS Miami Subdistrict office 305-717-5800

Additional comments:

Note for Monthly List of Publications: Biscayne Bay has historically relied on substantial quantities of freshwater from submarine springs and overland sheetflow to sustain its estuarine ecosystem. During the past century, freshwater delivery has changed to that of periodic freshwater release from the mouths of canals. This report attempted to document the development of a regional-scale, three-dimensional numerical model that would simulate variable-density groundwater discharge to Biscayne Bay as well as present an estimate of submarine discharge to the bay. Model results were variable and reported in relative terms rather than absolute values.

How many boxes to be expected:

Short title: $\quad$ GW Discharge (modeling) to Biscayne Bay, Fla.

Quantity in box: 2 boxes holding 22 cys each

Year of product: 2001 


\title{
Simulation of Ground-Water Discharge to Biscayne Bay, Southeastern Florida
}

\author{
By Christian D. Langevin
}

U.S. GEOLOGICAL SURVEY

Water-Resources Investigations Report 00-4251

\section{Prepared as part of the}

U.S. GEOLOGYCAL SURVEY Place-Based Studies Program

and in cooperation with the

U.S. ARMY CORPS OF ENGINEERS 


\title{
U.S. DEPARTMENT OF THE INTERIOR GALE A. NORTON, Secretary
}

\author{
U.S. GEOLOGICAL SURVEY \\ CHARLES G. GROAT, Director
}

Use of trade, product, or firm names in this publication is for descriptive purposes only and does not imply endorsement by the U.S. Geological Survey.

For additional information write to:

District Chief

U.S. Geological Survey

Suite 3015

227 N. Bronough Street

Tallahassee, FL 32301
Copies of this report can be purchased from:

U.S. Geological Survey Branch of Information Services Box 25286 Denver, CO 80225-0286 888-ASK-USGS

Additional information about water resources in Florida is available on the World Wide Web at http://fl.water.usgs.gov 


\section{CONTENTS}

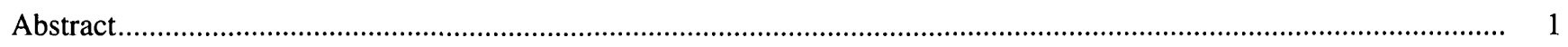

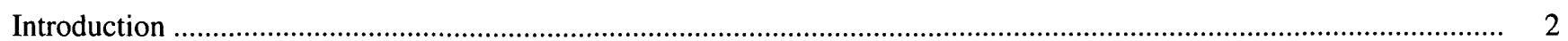

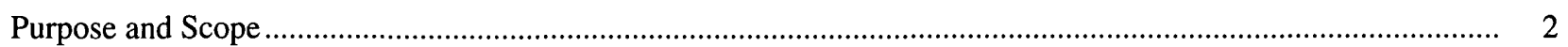

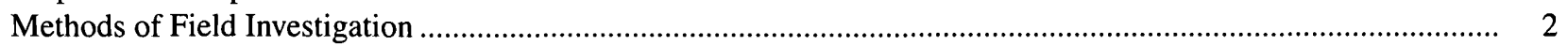

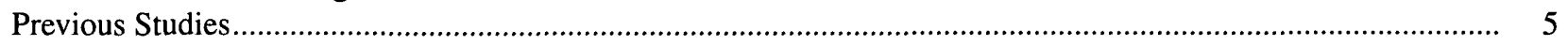

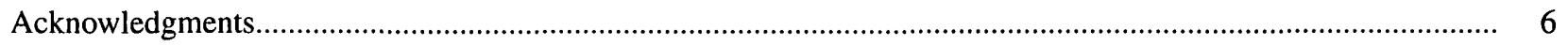

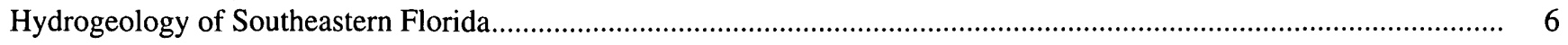

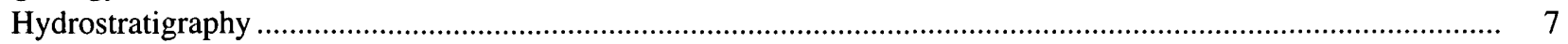

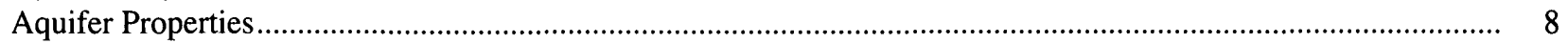

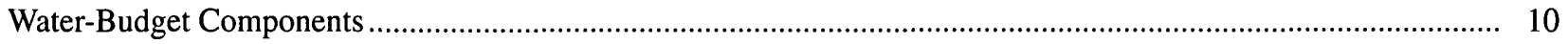

Rainfall, Evapotranspiration, and Runoff ....................................................................................... 10

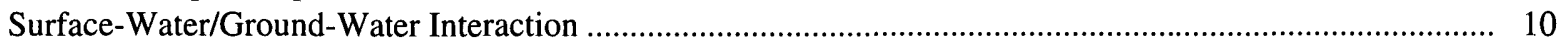

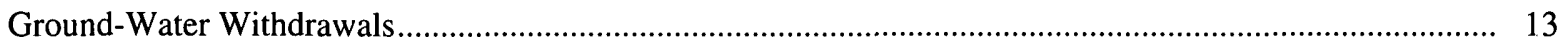

Freshwater-Saltwater Transition Zone ................................................................................................. 14

Simulation of Ground-Water Discharge to Biscayne Bay ........................................................................................ 22

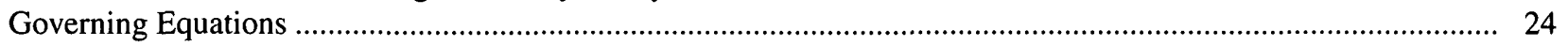

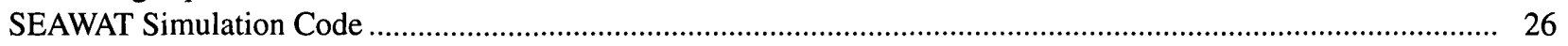

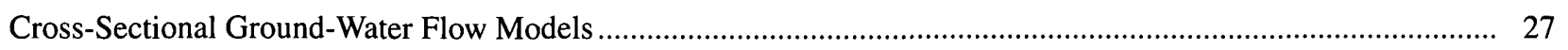

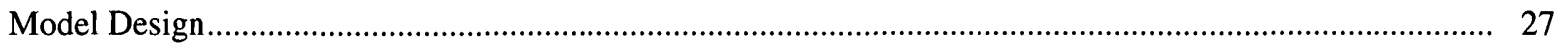

Model Calibration and Simulation Results ............................................................................................... 29

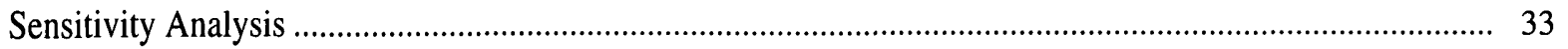

Regional-Scale Ground-Water Flow Model ................................................................................................ 34

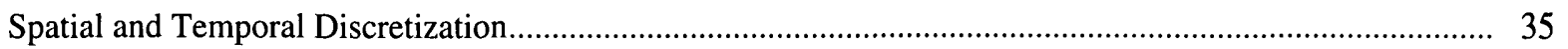

Assignment of Aquifer Parameters .................................................................................................... 35

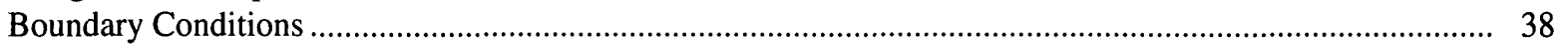

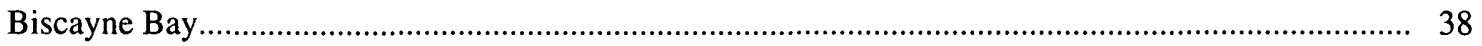

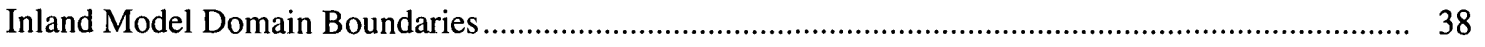

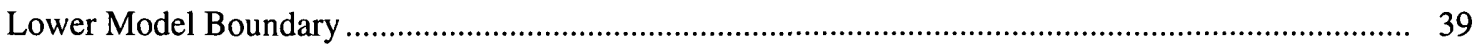

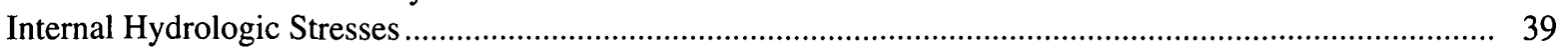

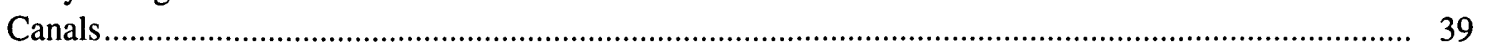

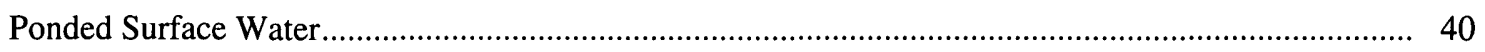

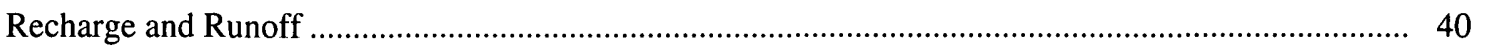

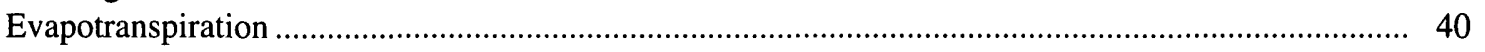

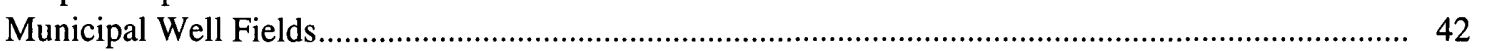

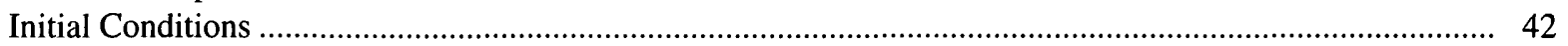

Calibration Procedure and Model Results ........................................................................................ 42

Comparison of Simulated and Observed Heads ............................................................................. 42

Comparison of Simulated and Observed Canal Baseflow............................................................. 43

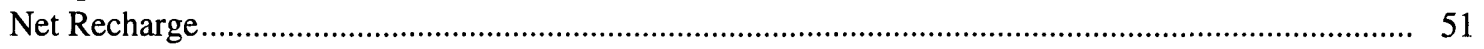

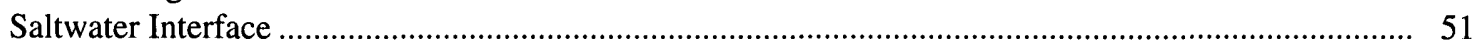

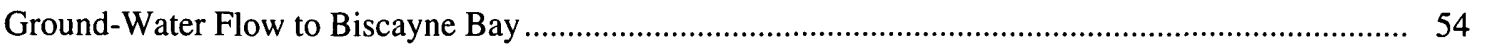

Sensitivity Analysis ......................................................................................................................... 56

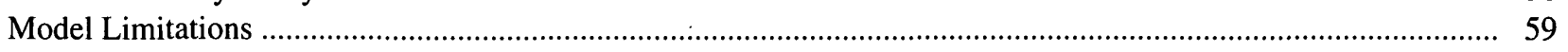

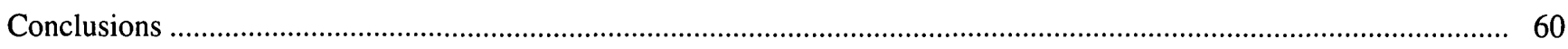

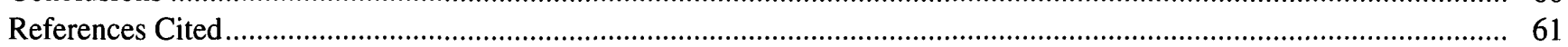

Appendix I: Lithologic Descriptions of Selected Cores as Determined for this Study ................................................... 67

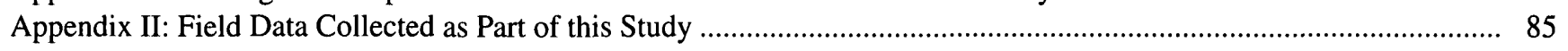

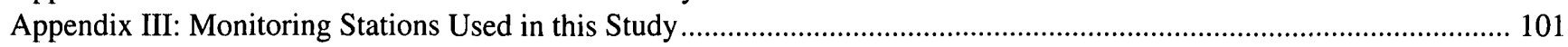

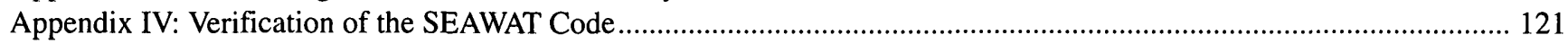




\section{PLATES}

1. Sections showing sensitivity analysis results for the Coconut Grove model

pocket

2. Sections showing sensitivity analysis results for the Deering Estate model

pocket

3. Maps showing boundary conditions, internal hydrologic stresses, and hydraulic conductivity

zonation of the regional-scale model.

pocket

\section{FIGURES}

1-2. Maps showing:

1. Location of study area, domain of regional-scale model, and location of field transects ..............................

2. Natural physiographic features of southern Florida

3. Hydrogeologic section showing relations of geologic formations, aquifers, and semipermeable units of the surficial aquifer system across central Miami-Dade County

4-5. Maps showing:

4. Water-table elevation for May 1993, Miami-Dade County, Florida.

5. Water-table elevation for November 1993, Miami-Dade County, Florida

6-10. Graphs showing:

6. Totals of annual and monthly rainfall, 1989-98

7. Municipal well-field withdrawals from the Biscayne aquifer in Miami-Dade County from January 1989 to September 1998

8. Lines of equal chloride concentration and results from a flow-net analysis for the Cutler Ridge area, September 18, 1958.

9. Lines of equal chloride concentration for the Silver Bluff area, November 2, 1954.

10. Lines of equal chloride concentration from March 1998 to February 1999 for the Coconut Grove, Deering Estate, and Mowry Canal transects

11-12. Maps showing:

11. Location of saltwater intrusion lines in southern Florida based on previous studies, the Ghyben-Herzberg relation, and a geophysical survey.

12. Ground-water monitoring wells in the Biscayne aquifer used to monitor the location of the saltwater intrusion line in Miami-Dade County ....

13-14. Graphs showing:

13. Chloride concentrations relative to time for selected monitoring wells in Miami-Dade County

14. Stage fluctuations in Biscayne Bay, Florida, 1989-99, plotted as average daily and monthly averages and hourly values

15. Three-dimensional diagram showing conceptual hydrologic model used to develop numerical models of ground-water flow.....

16. Map showing location of the two-dimensional, cross-sectional models for Coconut Grove and Deering Estate .. 28

17. Grids showing boundary conditions and finite-difference grid for the Coconut Grove and Deering

Estate models.

18. Cross sections showing calibration results for the Coconut Grove and Deering Estate models

19-20. Graphs showing:

19. Simulated ground-water discharge to Biscayne Bay for the Deering Estate model

20. Simulated water budget for the Coconut Grove and Deering Estate models

21-24 Maps showing:

21. Finite-difference grid for the regional-scale ground-water flow model in southern Florida

22. Land-surface elevation of southern Florida used in the regional-scale ground-water flow model

23. Land use of southern Florida for 1995

24. Location of ground-water monitoring wells in southern Florida used to calibrate the regional-scale ground-water flow model and average differences between observed and simulated values of head

25-26. Graphs showing:

25. Comparison between observed and simulated monthly average heads for selected monitoring wells near the coast

26. Calibration statistics for errors between observed heads and heads simulated by the regional-scale ground-water flow model 
27. Map showing location of surface-water basins in southern Florida and the mean absolute error between observed and simulated canal baseflow

28. Graphs showing comparison between observed and simulated values of monthly average canal baseflow for selected surface-water basins.

29-30. Maps showing:

29. Simulated values of average annual net recharge from the regional-scale ground-water flow model for 1989-98

30. Simulated values of ground-water salinity at the base of the Biscayne aquifer compared with the 1995 saltwater intrusion line.

31. Graphs showing:

31. Total salt mass in the Biscayne aquifer as simulated by the regional-scale ground-water flow model.

32. Simulated fresh ground-water discharge to Biscayne Bay.

33. Simulated fresh ground-water discharge compared with measured surface-water discharge to Biscayne Bay

34. Graphs showing sensitivity analysis of regional-scale model depicting range of simulated fresh ground-water discharge to Biscayne Bay

A1. Schematic showing boundary conditions and model parameters for the Henry problem ................................... 123

A2. Graphs showing comparison between SEAWAT and SUTRA for the Henry problem .................................. 124

A3. Schematic showing boundary conditions and model parameters for the Elder problem ................................ 125

A4. Schematics showing comparison between SEAWAT, SUTRA, and Elder's solution for the Elder problem.......... 126

A5. Schematic showing boundary conditions and model parameters for the HYDROCOIN problem ...................... 127

A6. Graph showing comparison between SEAWAT and MOCDENSE for the HYDROCOIN problem ................... 127

\section{TABLES}

1. Properties of ground-water monitoring wells installed for this study

2. Field data used to construct cross sections of chloride concentration and calibrate cross-sectional models ......... 17

3. Results from the time-domain electromagnetic (TDEM) soundings near Mowry Canal .................................. 18

4. Aquifer parameters and boundary stresses used in the calibrated cross-sectional models ................................ 31

5. Runoff coefficients and evapotranspiration extinction depths for different land-use categories ....................... 40

\section{EQUATIONS}

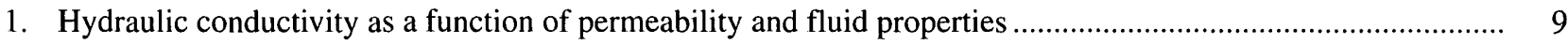

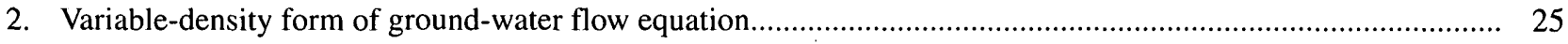

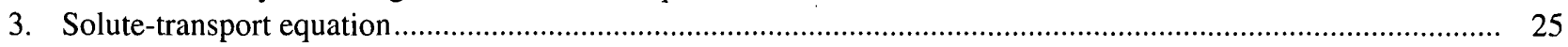

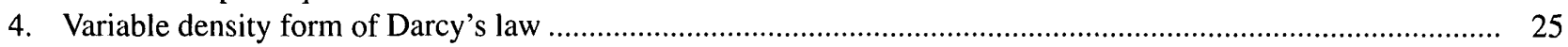

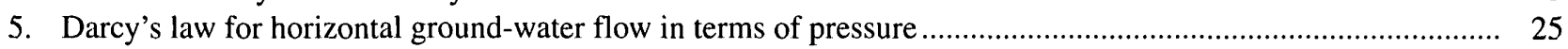

6. Darcy's law for vertical ground-water flow in terms of pressure ............................................................ 25

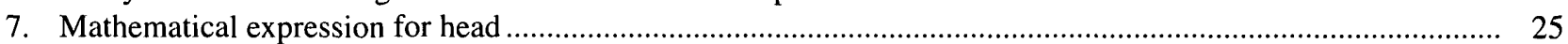

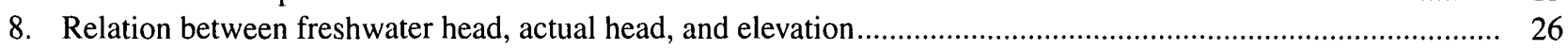

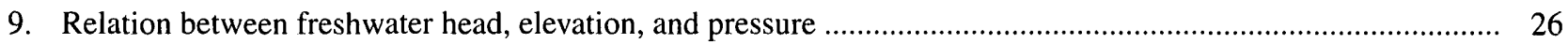

10. Darcy's law for horizontal ground-water flow in terms of freshwater head ................................................ 26

11. Darcy's law for vertical ground-water flow in terms of freshwater head ................................................... 26

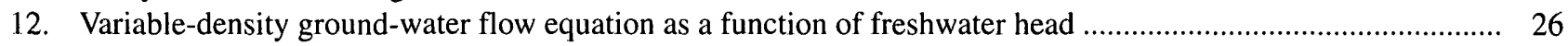




\begin{tabular}{r|cl}
\hline \multicolumn{2}{|r|}{ Conversion Factors, Abbreviations, and Datum } \\
Multiply & By & To obtain \\
centimeter & 0.3937 & inch \\
centimeter per year & 0.3937 & inch per year \\
meter & 3.2808 & foot \\
meter per day & 3.2808 & foot per day \\
square meter & 10.7636 & square foot \\
square meter per day & 10.7636 & square foot per day \\
cubic meter & 35.3134 & cubic foot \\
cubic meter per day & 35.3134 & cubic foot per day \\
cubic meter per day & $4.0872 \times 10^{-4}$ & cubic foot per second \\
kilometer & 264.2 & gallon per day \\
kilogram & 0.6214 & mile \\
kilogram per cubic meter & 0.2046 & pound \\
& & pound per cubic foot \\
& & \\
& & \\
& &
\end{tabular}

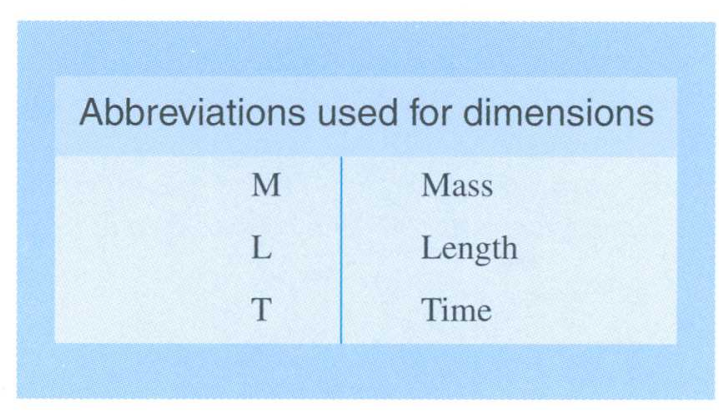

Sea level: In this report, "sea level" refers to the National Geodetic Vertical Datum of 1929_a geodetic datum derived from a general adjustment of the first-order level nets of both the United States and Canada, formerly called Sea Level Datum of 1929. 


\title{
Simulation of Ground-Water Discharge to Biscayne Bay, Southeastern Florida
}

\author{
By Christian D. Langevin
}

\section{Abstract}

As part of the Place-Based Studies Program, the U.S. Geological Survey initiated a project in 1996, in cooperation with the U.S. Army Corps of Engineers, to quantify the rates and patterns of submarine ground-water discharge to Biscayne Bay. Project objectives were achieved through field investigations at three sites (Coconut Grove, Deering Estate, and Mowry Canal) along the coastline of Biscayne Bay and through the development and calibration of variable-density, ground-water flow models. Twodimensional, vertical cross-sectional models were developed for steady-state conditions for the Coconut Grove and Deering Estate transects to quantify local-scale ground-water discharge patterns to Biscayne Bay. A larger regional-scale model was developed in three dimensions to simulate submarine ground-water discharge to the entire bay. The SEAWAT code, which is a combined version of MODFLOW and MT3D, was used to simulate the complex variable-density flow patterns.

Field data suggest that ground-water discharge to Biscayne Bay relative to the shoreline is restricted to within 300 meters at Coconut Grove, 600 to 1,000 meters at Deering Estate, and 100 meters at Mowry Canal. The vertical crosssectional models, which were calibrated to the field data using the assumption of steady state, tend to focus ground-water discharge to within 50 to 200 meters of the shoreline. With homogeneous distributions for aquifer parameters and a constant-concentration boundary for Biscayne Bay, the numerical models could not reproduce the lower ground-water salinities observed beneath the bay, which suggests that further research may be necessary to improve the accuracy of the numerical simulations. Results from the crosssectional models, which were able to simulate the approximate position of the saltwater interface, suggest that longitudinal dispersivity ranges between 1 and 10 meters, and transverse dispersivity ranges from 0.1 to 1 meter for the Biscayne aquifer.

The three-dimensional, regional-scale model was calibrated to ground-water heads, canal baseflow, and the general position of the saltwater interface for nearly a 10-year period from 1989 to 1998. The mean absolute error between observed and simulated head values is 0.15 meter. The mean absolute error between observed and simulated baseflow is $3 \times 10^{5}$ cubic meters per day. The position of the simulated saltwater interface generally matches the position observed in the field, except for areas north of the Miami Canal where the simulated saltwater interface is located about 5 kilometers inland of the observed saltwater interface. Results from the regional-scale model suggest that the average rate of fresh ground-water discharge to Biscayne Bay for the 10-year period (1989-98) is about $2 \times 10^{5}$ cubic meters per day for 100 kilometers of coastline. This simulated discharge rate is about 6 percent of the measured surface-water discharge to Biscayne Bay for the same period. The model also suggests that nearly 100 percent of the fresh ground-water discharge is to the northern half of Biscayne Bay, north of the Cutler Drain Canal. 
South of the Cutler Drain Canal, coastal lowlands prevent the water table from rising high enough to drive measurable quantities of ground water to Biscayne Bay. Annual variations in sea-level elevation, which can be as large as 0.3 meter, have a substantial effect on rates of ground-water discharge. During 1989-98, simulated rates of ground-water discharge to Biscayne Bay generally are highest when sea level is relatively low.

\section{INTRODUCTION}

Biscayne Bay is a coastal barrier-island lagoon that relies on substantial quantities of freshwater to sustain its estuarine ecosystem. During the past century, field observations suggest that the mechanism for the delivery of freshwater to Biscayne Bay has changed from a system largely controlled by widespread and continuous submarine discharge and overland sheetflow to one controlled by episodic releases of surface water at the mouths of canals. Current ecosystem restoration efforts in southern Florida are examining alternative water-management scenarios that could further change the quantity and timing of freshwater delivery to the bay. There is concern that these proposed modifications could adversely affect bay salinities.

To evaluate the effects of the modifications on Biscayne Bay, the U.S. Army Corps of Engineers (USACE) is constructing a surface-water hydrodynamic circulation model. To achieve a reasonable calibration, this model requires the accurate specification of freshwater discharges to the bay. The two most important mechanisms for freshwater discharge to Biscayne Bay are thought to be canal discharges and submarine ground-water discharge from the Biscayne aquifer. Canal discharges are routinely measured and recorded, but few studies have attempted to quantify the rates and patterns of submarine ground-water discharge. Depending on the method, estimates of submarine ground-water discharge can range over several orders of magnitude.

As part of the Place-Based Studies program, the U.S. Geological Survey (USGS), in cooperation with the USACE, initiated a project in 1996 to quantify the rates and patterns of submarine ground-water discharge to Biscayne Bay. This was accomplished through field investigation and ground-water flow simulation at three sites along the coastline of Biscayne Bay and development of a numerical ground-water flow model that covers most of MiamiDade County and parts of Broward and Monroe Counties (fig. 1). Study results have been incorporated into the hydrodynamic circulation model under development by the USACE.

\section{Purpose and Scope}

The purposes of this report are to: (1) document the development of a regional-scale, three-dimensional numerical model that simulates variable-density ground-water discharge to Biscayne Bay, and (2) present an estimate of submarine ground-water discharge to Biscayne Bay. To properly simulate ground-water flow, processes affecting ground-water flow were characterized and represented mathematically. Two local-scale models were developed in cross section to simulate the complex ground-water discharge patterns near the coast of Biscayne Bay. Ground-water data collected for this study from March 1997 to February 1998 are presented and used with an assumption of steady-state conditions to calibrate the cross-sectional models. Results from the crosssectional models were used to aid development of the regional-scale model that simulates transient groundwater discharge in three dimensions. The regionalscale model was calibrated with field data from 1989 through 1998 to ensure it is a reasonable representation of the physical system.

\section{Methods of Field Investigation}

A field investigation was conducted to collect data that would help quantify ground-water discharge to Biscayne Bay. The design of the field investigation was based on the general and widely accepted concept that fresh ground water flowing toward a coastal boundary will flow up and over a saltwater wedge. To better characterize this flow pattern within the study area, three transects, each located on a ground-water flow line toward Biscayne Bay, were selected for further study. The locations of these transects, referred to as Coconut Grove, Deering Estate, and Mowry Canal, are shown in figure 1. 


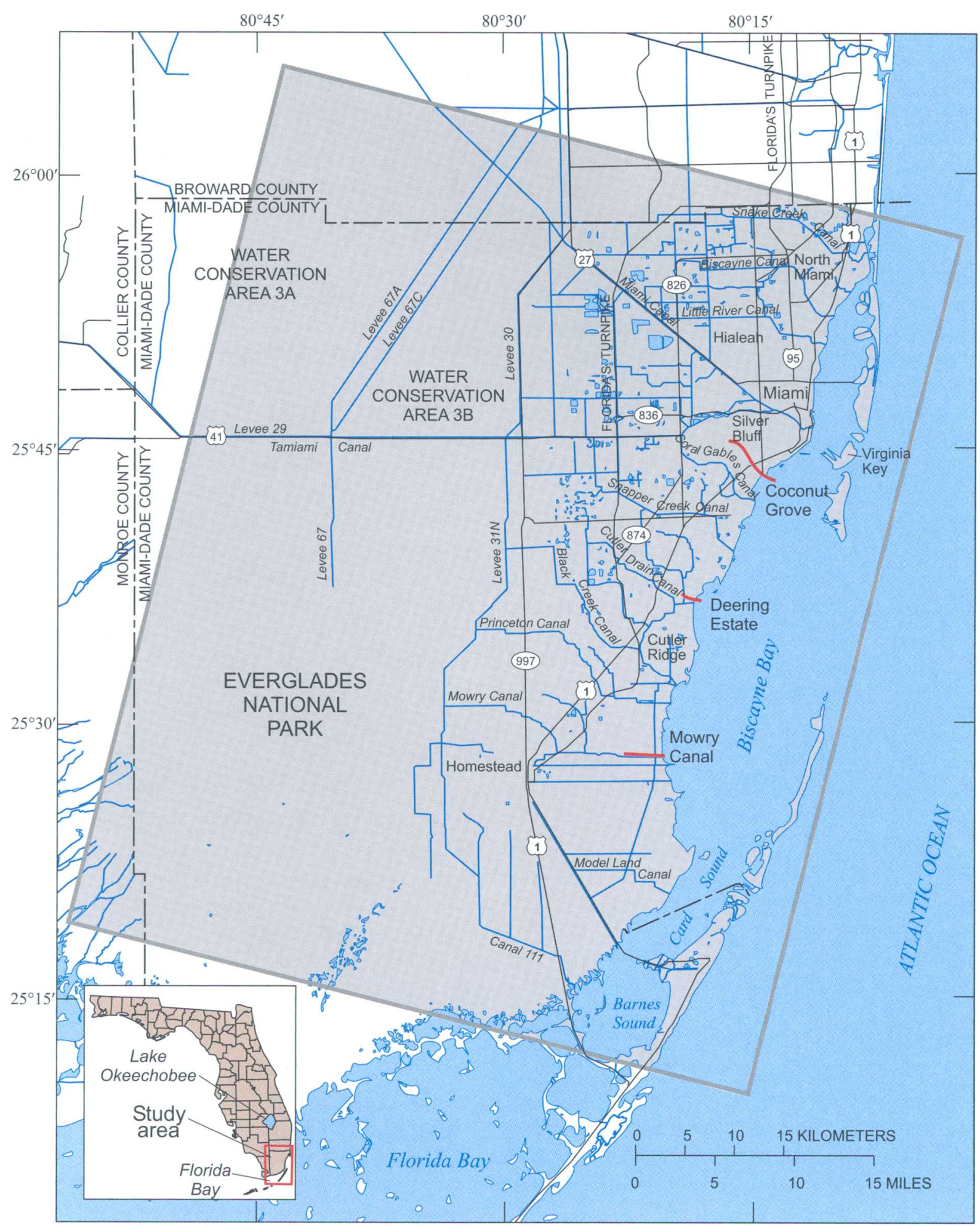

\section{EXPLANATION}

Model grid area $\quad$ Canal or stream

$\rightarrow$ Lake - Road

Figure 1. Southern Florida showing location of study area, domain of regional-scale model, and location of field transects. 
The field investigation was initiated by installing ground-water monitoring wells at each of the three transects. In an effort to fully characterize the transition zone between fresh and saline ground water, monitoring wells were installed both inland and offshore. Inland monitoring wells were installed by the Florida Geological Survey, and the offshore monitoring wells were installed by the USGS. The offshore wells were installed from a floating barge using the methods presented in Shinn and others (1994). Coordinates, screened intervals, and other specifications for these and other monitoring wells installed for this study are given in table 1 .

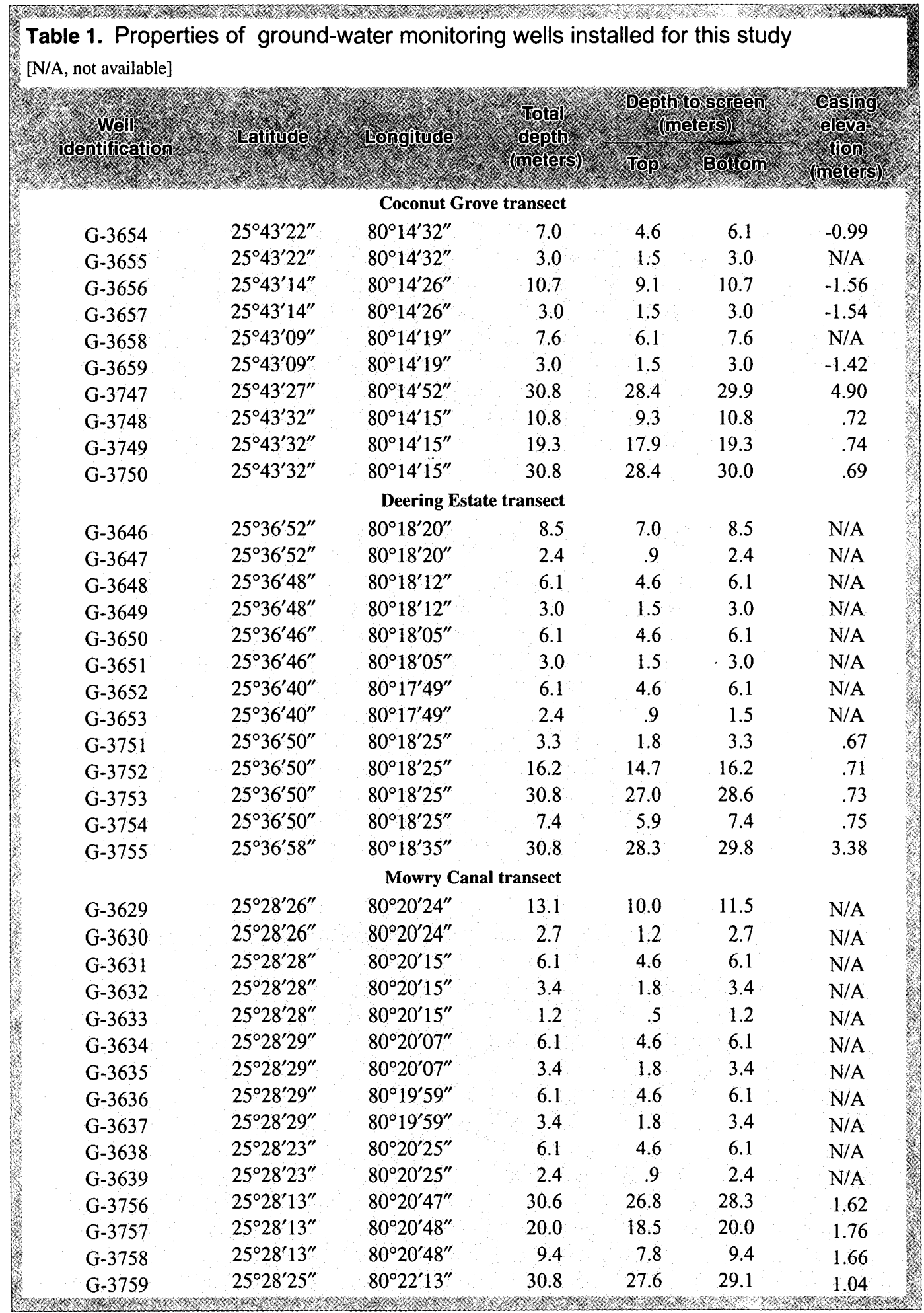


During the installation of selected monitoring wells, lithologic cores were collected and analyzed to provide a better understanding of the stratigraphy and hydrogeologic characteristics at the monitoring well locations (app. I). Permeameter analyses were performed on several rock samples extracted from the cores, but the analyses were inconclusive. For selected inland monitoring wells, geophysical logging was performed by the South Florida Water Management District prior to setting the steel surface casing.

Water samples were collected with a centrifugal pump from selected monitoring wells for each month from March 1998 to February 1999. Measurements of depth to water were recorded prior to sampling, and if the well had been leveled, a water-table elevation was calculated. During the first 3 months, water samples were analyzed by the USGS for chloride concentration, $\left[\mathrm{Cl}^{-}\right]$, using the titration method (Brown and others, 1974). Measurements of specific conductance (SC) also were performed on the ground-water samples. These data are included in appendix II. After 3 months of directly measuring chloride concentrations, it was determined that chloride concentrations could be adequately estimated from measurements of specific conductance, which are easier to perform. Chloride concentrations for all subsequent groundwater samples were estimated from specific conductance using the following equation:

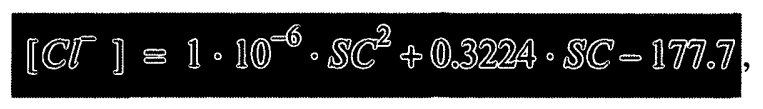

where $\left[\mathrm{Cl}^{-}\right]$is in milligrams per liter and $S C$ is in microsiemens per centimeter. This polynomial equation was created by a fit to 120 measurements of specific conductance and chloride concentrations and represents the data with a correlation coefficient $\left(R^{2}\right)$ of 0.9967 .

The numerical model used in this study requires concentrations of total dissolved solids (TDS) rather than chloride concentrations. Chloride concentrations were linearly converted to TDS by assuming that seawater has a chloride concentration of $19,800 \mathrm{mg} / \mathrm{L}$ (milligrams per liter) and a TDS value of $35,000 \mathrm{mg} / \mathrm{L}$ (Parker, and others, 1955). Fish (1988) estimates that water-rock interactions in the surficial aquifer of southeastern Florida can affect the TDS value by 350 to $550 \mathrm{mg} / \mathrm{L}$; therefore, the TDS values in this study, which were estimated from chloride concentrations, may contain a 1 to 2 percent error relative to the observed range of TDS values. This suggests that a linear relation between chloride and TDS is reasonable, even for ground-water samples.

During the initial part of the field investigation, much time was spent trying to obtain reliable results from seepage meters. A seepage meter is a cylindrical tube that is pressed into the bottom sediments of a surface-water body; seepage rates are determined by measuring liquid volumes in a bag attached to the tube. After many unsuccessful attempts, it was determined that seepage meters could not be used within the tidal environment of Biscayne Bay because flow rates measured at seepage meters were not in agreement with tidal phase, or were not proportional to vertical head differences at nested offshore monitoring wells. There is evidence that seepage meters may not work in tidal environments or under certain conditions because they may be artificially pumped from tides, waves, and fluctuations in barometric pressure (C. Reich, U.S. Geological Survey, oral commun., 2000). This artificial pumping can result in seepage measurements that are not representative of the actual seepage rate.

To better delineate the position of the saltwater interface, time-domain electromagnetic (TDEM) soundings were made at the Mowry Canal transect. The TDEM method has been successfully used in southern Florida to locate the saltwater interface (Sonenshein, 1997; Fitterman and others, 1999; and Hittle, 1999) and lithologic boundaries (Shoemaker, 1998). The TEMIX software (Interpex Limited, 1996) was used to invert the geophysical data. The approach described by Fitterman and others (1999) was used to interpret the inverted TDEM data and determine approximate depths of the saltwater interface.

\section{Previous Studies}

Taniguchi and others (1999) compiled rates of submarine ground-water discharge from around the world. He concludes that most measured seepage rates are less than $0.1 \mathrm{~m} / \mathrm{d}$ (meter per day), a rate that includes recirculated seawater. Byrne (1999) used seepage meters and a form of Darcy's law to estimate ground-water discharge to Biscayne Bay. He found that most of the ground-water discharge occurred within the first $400 \mathrm{~m}$ (meters) of shore. His estimates of submarine ground-water discharge range from 10 to $20 \mathrm{~m}^{3} / \mathrm{d}$ (cubic meters per day) per meter of shoreline. Assuming that ground-water discharge occurs only within the first $400 \mathrm{~m}$ from shore, Byrne's (1999) 
average discharge estimates range from 0.025 to $0.050 \mathrm{~m} / \mathrm{d}$, similar to the average rate compiled by Taniguchi and others (1999). Byrne's (1999) estimates of total ground-water discharge also include the volume of recirculated seawater.

From the 1940's to the 1960's, many studies on the Biscayne aquifer and in particular saltwater intrusion in Miami-Dade County were conducted. Results are presented in publications by Brown and Parker (1945), Parker (1945), Parker (1951), Parker and others (1955), Klein (1957), Cooper (1959), Kohout (1960a), Kohout (1960b), Kohout (1961a), Kohout (1961b), Kohout and Hoy (1963), Kohout (1964), Cooper and others (1964), Kohout and Klein (1967), and Kohout and Kolipinski (1967). Since those early studies, saltwater intrusion into the Biscayne aquifer has been periodically evaluated and summarized by Hull and Meyer (1973), Klein and Waller (1985), Klein and Ratzlaff (1989), Sonenshein and Koszalka (1996), Sonenshein (1997), and Konikow and Reilly (1999).

Numerical models of ground-water flow have been constructed for southern Miami-Dade County (Merritt, 1996a; Swain and others, 1996) and northern Miami-Dade County (Mark Wilsnak, South Florida Water Management District, written commun., 1999) to evaluate water-supply issues, but these models do not contain a variable-density component. Development of county-wide variable-density models is not common practice because of numerical difficulties and the computer capabilities required to simulate variable-density flow in three dimensions. These types of difficulties are highlighted by Oude Essink and Boekelman (1996).

Cross-sectional models of ground-water flow in coastal environments have been developed to evaluate saltwater intrusion. A numerical model of saltwater intrusion was developed for Hallandale, Fla. (Andersen and others, 1988). The saltwater interface at Cutler Ridge, Fla., has been simulated by several investigators including Lee and Cheng (1974), Segol and Pinder (1976), Kwiatkowski (1987), and Hogg (1991).

\section{Acknowledgments}

The author would like to acknowledge managers and scientists from the USACE and the MiamiDade Department of Environmental Resource Management, particularly Mike Choate, Glenn Landers, Greg Nail, Bob Evans, Gwen Burczycki, and Sue Alspah. The author also would like to acknowledge the contribution from scientists of the USGS, including Roy Sonenshein, Vicente Quinones-Aponte, Eric Swain, Lillian Feltman, Eve Kuniansky, Barbara Howie, James Robinson, Gene Shinn and Chris Reich. Appreciation is extended to several individuals who provided field or technical assistance, including USGS employees Melinda Wolfert, Raul Patterson, Alyssa Dausman, Erik Swenson, and David Schmerge; Kevin Kotun from Everglades National Park; Bertha Goldenberg from Miami-Dade Water and Sewer Authority; Rusty Mason and Mark Wilsnak from the South Florida Water Management District; and Weixing Guo from CDM-Missimer International, Inc. Figures and illustrations were prepared by Jim Tomberlin, Ron Spencer, and Kimberly Swidarski; the layout was done by Pat Mixson. Careful and insightful reviews of this report were provided by Roy Sonenshein, Dr. Weixing Guo, Dr. John Wang, Mike Merritt, Rhonda Howard, Mike Deacon, Sandy Cooper, Barbara Howie, Eve Kuniansky, and Maggie Irizarry.

\section{HYDROGEOLOGY OF SOUTHEASTERN FLORIDA}

The hydrology of southeastern Florida is unique because of the dynamic interaction between ground water and surface water. One of the most striking surface-water features in southern Florida is the Everglades, often referred to as the "river of grass," which flows south from Lake Okeechobee to Florida Bay. North of the Tamiami Canal, the Everglades are divided into water-conservation areas (fig. 1). These conservation areas, although originally part of the continuous Everglades "river," are now separated by canals, highways, and levees. South of the Tamiami Canal, the Everglades is uncontrolled in Everglades National Park, which extends to Florida Bay (fig. 1).

The Atlantic Coastal Ridge separates the Everglades from the Atlantic Ocean and Biscayne Bay (fig. 2). The ridge is about 5 to $15 \mathrm{~km}$ (kilometers) wide and roughly parallels the coast in the northern half of Miami-Dade County. In southern Miami-Dade County, the Atlantic Coastal Ridge is located farther inland and low-lying coastal marshes and mangrove swamps adjoin Biscayne Bay. Historically, the transverse glades (low-lying areas that cut through the Atlantic Coastal Ridge) allowed high-standing surface water in the Everglades to drain into Biscayne Bay. 


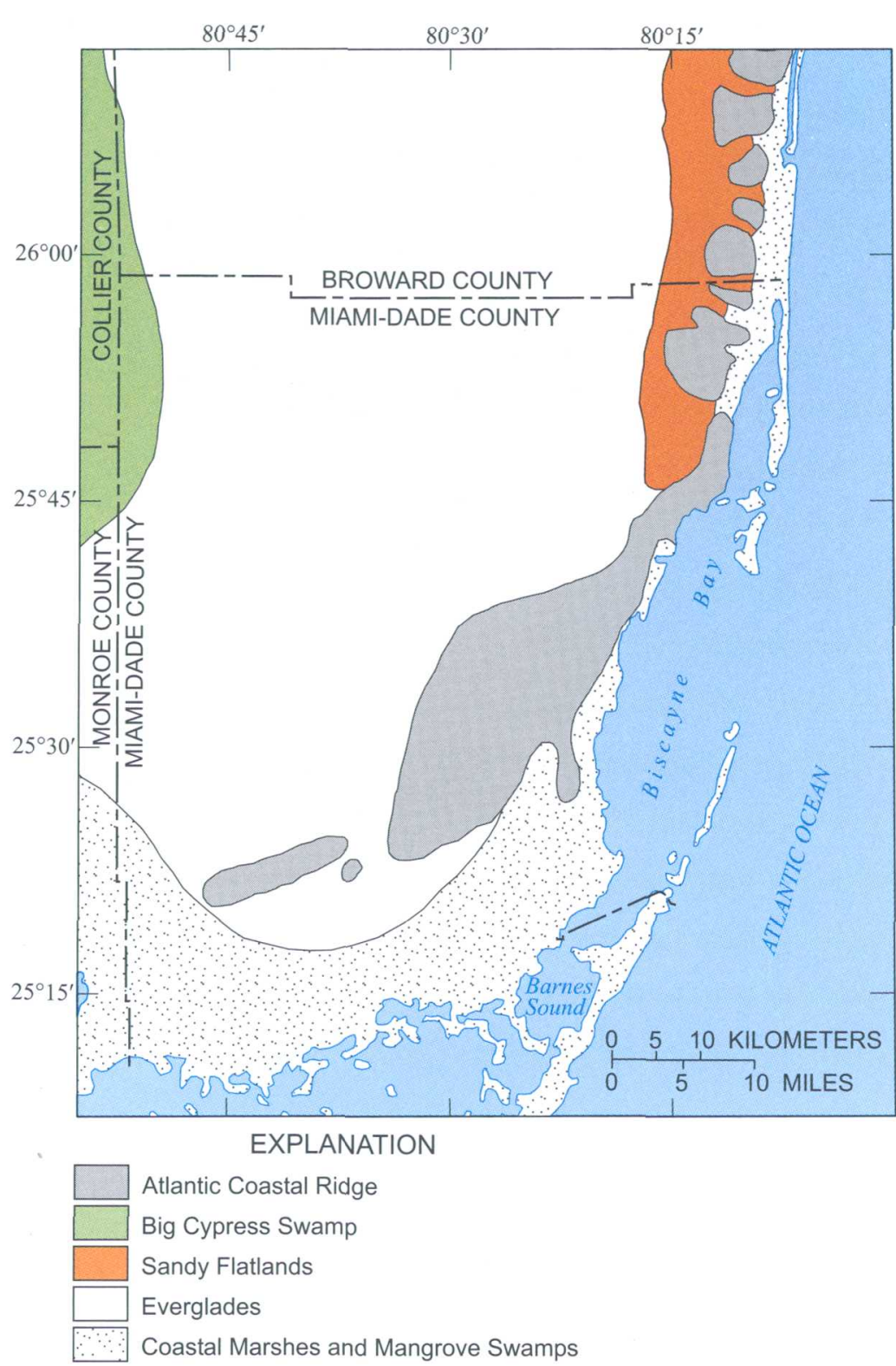

Figure 2. Natural physiographic features of southern Florida (from Parker and others, 1955).

Anecdotal evidence suggests that prior to the construction of the canal network in southern Florida, submarine springs discharged ground water into Biscayne Bay. There are historical accounts of sailors lowering buckets into freshwater boils to replenish their potable water supplies. Beginning in the early 1900 's, canals were constructed to lower the water table, increase the available land for agriculture, and provide flood protection. By the 1950's, excessive draining lowered the water table 1 to $3 \mathrm{~m}$ and caused saltwater intrusion, thus endangering the freshwater resources of the Biscayne aquifer. In response to saltwater intrusion, control structures were built near the mouths of canals to raise inland ground-water levels.

\section{Hydrostratigraphy}

The hydrostratigraphy of southeastern Florida is characterized by the shallow surficial aquifer system and the deeper Floridan aquifer system. The work of Parker and others (1955) and Kohout (1960a) suggests that the ground water discharging to Biscayne Bay originates from the Biscayne aquifer, which is part of the surficial aquifer system. This description of the hydrogeologic framework, therefore, focuses on the Biscayne aquifer.

The highly permeable Biscayne aquifer principally consists of porous limestone that ranges in age from Pliocene to Pleistocene. The vertical extent of the Biscayne aquifer does not

Throughout much of the study area, a complex network of levees, canals, and control structures is used to manage the water resources. The major canals, operated and maintained by the South Florida Water Management District, are used to prevent low areas from flooding and prevent saltwater intrusion into the Biscayne aquifer. These water-management canals primarily have been constructed in the low-lying transverse glades to more effectively route surface water toward Biscayne Bay. directly correlate with geologic contacts (fig. 3). Instead, the Biscayne aquifer is defined by hydrogeologic properties. Fish (1988, p. 20) defines the Biscayne aquifer as:

"That part of the surficial aquifer system in southeastern Florida comprised (from land surface downward) of the Pamlico Sand, Miami Oolite [Limestone], Anastasia Formation, Key Largo Limestone, and Fort Thompson Formation all of Pleistocene age, and contiguous highly 
West

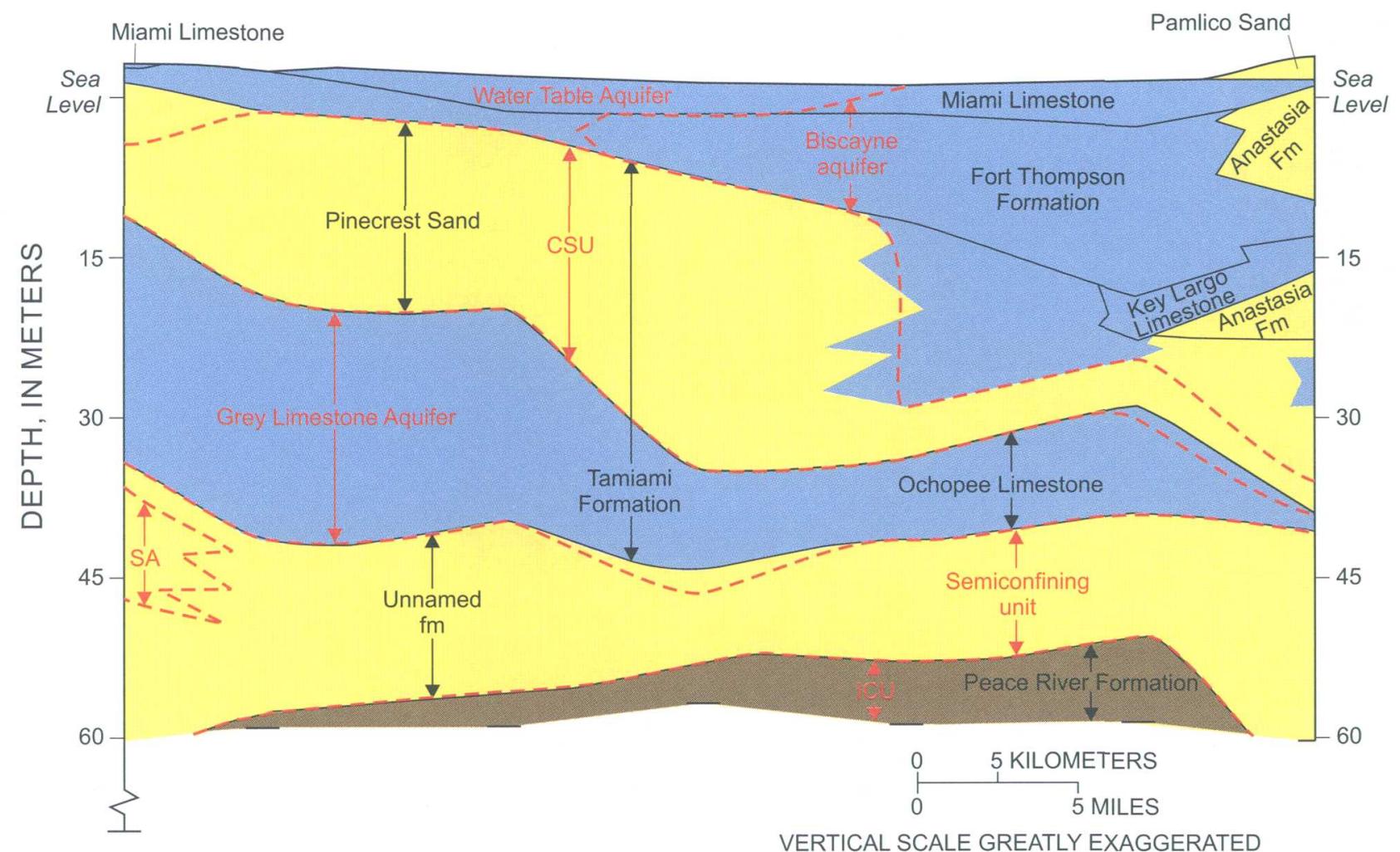

EXPLANATION

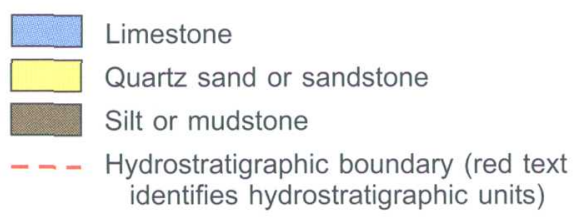
_ Lithostratigraphic boundary (black text identifies lithostratigraphic units)
CSU Confining to semiconfining unit
ICU Intermediate confining unit
SA Sand aquifer
Fm Formation

Figure 3. Relations of geologic formations, aquifers, and semipermeable units of the surficial aquifer system across central Miami-Dade County (from Reese and Cunningham, 2000).

permeable beds of the Tamiami Formation of Pliocene age, where at least $10 \mathrm{ft}[3.05 \mathrm{~m}]$ of the section is highly permeable - a horizontal hydraulic conductivity of about $1,000 \mathrm{ft} / \mathrm{d}[305 \mathrm{~m} / \mathrm{d}]$ or more."

The properties and extent of the Biscayne aquifer in Miami-Dade County are presented in a report by Fish and Stewart (1991). Based on the results from numerous lithologic cores, Fish and Stewart (1991) developed a contour map of the base of the Biscayne aquifer. The map illustrates the three-dimensional extent of the aquifer in Miami-Dade County and shows the aquifer thinning toward the west.

\section{Aquifer Properties}

Characterization of three different types of aquifer properties is required for a study of ground-water flow in a coastal environment. These properties can be categorized as transmissive, storage, and dispersive properties. Transmissive properties include three related properties: intrinsic permeability, hydraulic conductivity, and transmissivity. Intrinsic permeability (or simply permeability) is a measure of how easily any particular fluid will flow through aquifer material. Permeability is strictly a measure of the aquifer medium and does not depend on fluid properties. Hydraulic 
conductivity is related to permeability with the following equation:

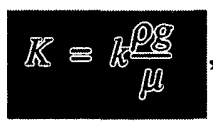

where

$K$ is hydraulic conductivity [L/T],

$k$ is intrinsic permeability $\left[\mathrm{L}^{2}\right]$,

$\rho$ is fluid density $\left[\mathrm{M} / \mathrm{L}^{3}\right]$,

$g$ is the acceleration due to gravity $\left[\mathrm{L} / \mathrm{T}^{2}\right]$, and

$\mu$ is the dynamic viscosity of the fluid [M/LT].

The $\rho g / \mu$ term in equation 1 represents properties of the fluid, whereas the $k$ term (intrinsic permeability) represents the aquifer medium. Hydraulic conductivity, therefore, is a property of the fluid and the medium. In the field, transmissive properties commonly are measured with ground-water pumping tests. These tests typically estimate transmissivity, which is the average hydraulic conductivity multiplied by the thickness of the aquifer. Fish and Stewart (1991, fig. 17) present a contour map of transmissivity for the Biscayne aquifer. Their map clearly illustrates the spatial variability in aquifer transmissivity, which must be accurately represented in a numerical model of ground-water flow. Within Miami-Dade County, values of transmissivity range from 0 to $1.9 \times 10^{5} \mathrm{~m}^{2} / \mathrm{d}$ (square meters per day) as reported by Fish and Stewart (1991).

Submerged ground-water springs in Biscayne Bay probably can be explained by the presence of preferential flow pathways, or conduits, within the Biscayne aquifer. Conduits are commonly found in limestone units because aggressive recharge waters preferentially dissolve the rock matrix along fractures and bedding planes. These solution cavities can affect ground-water flow by increasing the overall hydraulic conductivity of the aquifer.

Aquifers are typically referred to as confined or unconfined, depending on the storage properties of the aquifer. A confined aquifer is bounded on the top by a confining or semiconfining unit; when a well is installed in a confined aquifer, the water level in the well will rise above the base of the overlying confining unit. The elevation of the water level in the well is a measure of the potentiometric surface. When a well is pumped, the potentiometric surface declines in response to the pumping. The storage coefficient provides a measure of how quickly the potentiometric surface declines (or rises) in response to a hydrogeologic stress. For an unconfined aquifer such as the Biscayne, the water level in a well marks the position of the water table. Withdrawals from an unconfined aquifer lower the water table by dewatering pores. Conversely, pores are resaturated when the water table rises. The rate at which the water table rises and falls depends on the storage coefficient. For unconfined aquifers, the storage coefficient is usually referred to as specific yield. Merritt (1996a) performed an analysis of specific yield for a monitoring well in MiamiDade County. He estimated a specific yield value of 0.2 by analyzing water-table fluctuations in response to heavy rainfall events.

Chemical constituents dissolved in ground water will disperse as they flow through an aquifer. There are two main processes that cause dispersionmolecular diffusion and mechanical dispersion (Fetter, 1993). Molecular diffusion reduces concentration gradients by redistributing dissolved constituents from areas of high concentration to areas with lower concentration. Molecular diffusion slowly occurs over long periods of time and generally is considered negligible compared to mechanical dispersion, when mechanical dispersion occurs to a significant degree. Mechanical dispersion refers to the spreading of a plume or solute as a result of heterogeneities in the aquifer. These heterogeneities occur at many different scales (microscopic, macroscopic, local, and regional). The parameter that is used to describe the effects of heterogeneities on mechanical dispersion is called dispersivity and is dependent on the scale of the problem (Gelhar, 1986).

For the Biscayne aquifer, few studies have addressed dispersivity at the regional or county scale. In his simulation of a brackish water plume, Merritt (1996b) calibrated a numerical model with values of

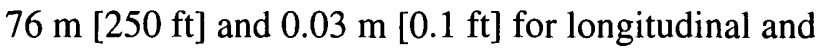
transverse dispersivity, respectively. Kwiatkowski

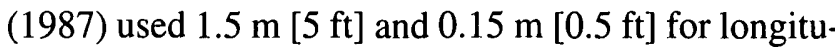
dinal and transverse dispersivity, respectively, for a numerical model of saltwater intrusion at the Deering Estate near Miami, Fla. The differences between these values of reported dispersivity most likely result from issues of scale; the study by Merritt (1996b) encompassed a much larger area than the study by Kwiatkowski (1987). 


\section{Water-Budget Components}

To properly simulate ground-water flow, it is necessary to understand and mathematically represent water-budget components that affect flow. This section identifies these components and summarizes their importance. Shallow ground-water flow is gravitationally driven by hydraulic gradients, which are caused by spatial variations in the height of the water table. Using this general principle, maps of the water table can be used in conjunction with an understanding of hydrogeologic characteristics to provide information regarding the processes that affect ground-water flow. A map report by Sonenshein and Koszalka (1996) displays the elevation of the water table in the Biscayne aquifer in Miami-Dade County for May 1993 (end of the dry season) and November 1993 (end of the wet season). Both maps (figs. 4 and 5) are discussed in this report because they represent the general state and seasonal variability of the water table in the study area.

\section{Rainfall, Evapotranspiration, and Runoff}

The water-table maps (figs. 4 and 5) suggest that the general flow of ground water is toward the coast. This implies that the Biscayne aquifer receives some form of recharge in order to maintain a water-table elevation above sea level. A comparison of figures 4 and 5 , also shows that this recharge quantity is seasonally variable because the elevation of the water table changes during the year. Recharge to the Biscayne aquifer is primarily driven by rainfall, with large quantities of the total rainfall lost to evapotranspiration and surface runoff. Rainfall, evapotranspiration, and runoff combine to form recharge and require characterization for appropriate treatment in a numerical flow model.

One of the most comprehensive collections of rainfall data for southern Florida is maintained by the South Florida Water Management District. The District database includes rainfall records for stations operated by Federal, State, and local agencies. Rainfall stations within the study area that had at least 1 month of record for the period from 1989 to 1998 were used to calculate average values of monthly rainfall (fig. 6) for the domain of the regional-scale model (fig. 1). From January 1989 through September 1998, the annual rainfall average was about $141 \mathrm{~cm} / \mathrm{yr}$ (centimeters per year); 75 percent of the rainfall occurred during the 5 wetseason months from June to October (fig. 6).

Evapotranspiration is defined as the rate of water loss to the atmosphere from evaporation and transpiration from plants. Direct measurements of evapotranspiration in the Everglades and other parts of southern Florida indicate that the rates are between 122 and $130 \mathrm{~cm} / \mathrm{yr}$ (E.R. German, U.S. Geological Survey, oral commun., 2000). These rates were measured in areas where the water table is relatively high and may not be indicative of the entire study area. These rates, however, are in agreement with those simulated by Merritt (1996a) and suggest that the average evapotranspiration in some areas may be 90 percent of annual rainfall.

Runoff is the percentage of rainfall that drains directly into a flowing surface-water body, such as a canal or river. Runoff values are complicated to estimate because they depend on the moisture content of soils, soil properties, land use, and so forth. When soils are fully saturated, more runoff occurs than when the soils are dry. Land-use types further complicate quantification of runoff. For example, many urban areas in southern Florida are developed with french drains that route stormwater directly into the aquifer. This type of process is considered aquifer recharge. In other areas of southern Florida, however, stormwater flows directly into canals. This quantity is runoff and does not directly recharge the aquifer. Detailed estimates of runoff are not available for southern Florida.

\section{Surface-Water/Ground-Water Interaction}

Based on the shapes of contours in the watertable maps (figs. 4 and 5), it is evident that the watermanagement canals have a substantial effect on ground-water flow within the study area. This is expected because the canals are in direct hydraulic connection with the highly permeable Biscayne aquifer. The canals recharge, or flow into, the Biscayne aquifer during the dry season (fig. 4) and drain the Biscayne aquifer during the wet season (fig. 5). From a hydrological perspective, the canals generally tend to serve the purpose for which they were designed. During the wet season, control structures within the canals are opened to allow discharge to Biscayne Bay. This drainage process lowers the water table and reduces the potential for flooding in urban and agricultural areas. During the dry season, surface water from farther inland is routed through the canal system to the coastal areas. This redistribution of surface water maintains relatively high water-table elevations near the coast and prevents saltwater intrusion. Based on their hydrologic influence, representation of canals in 


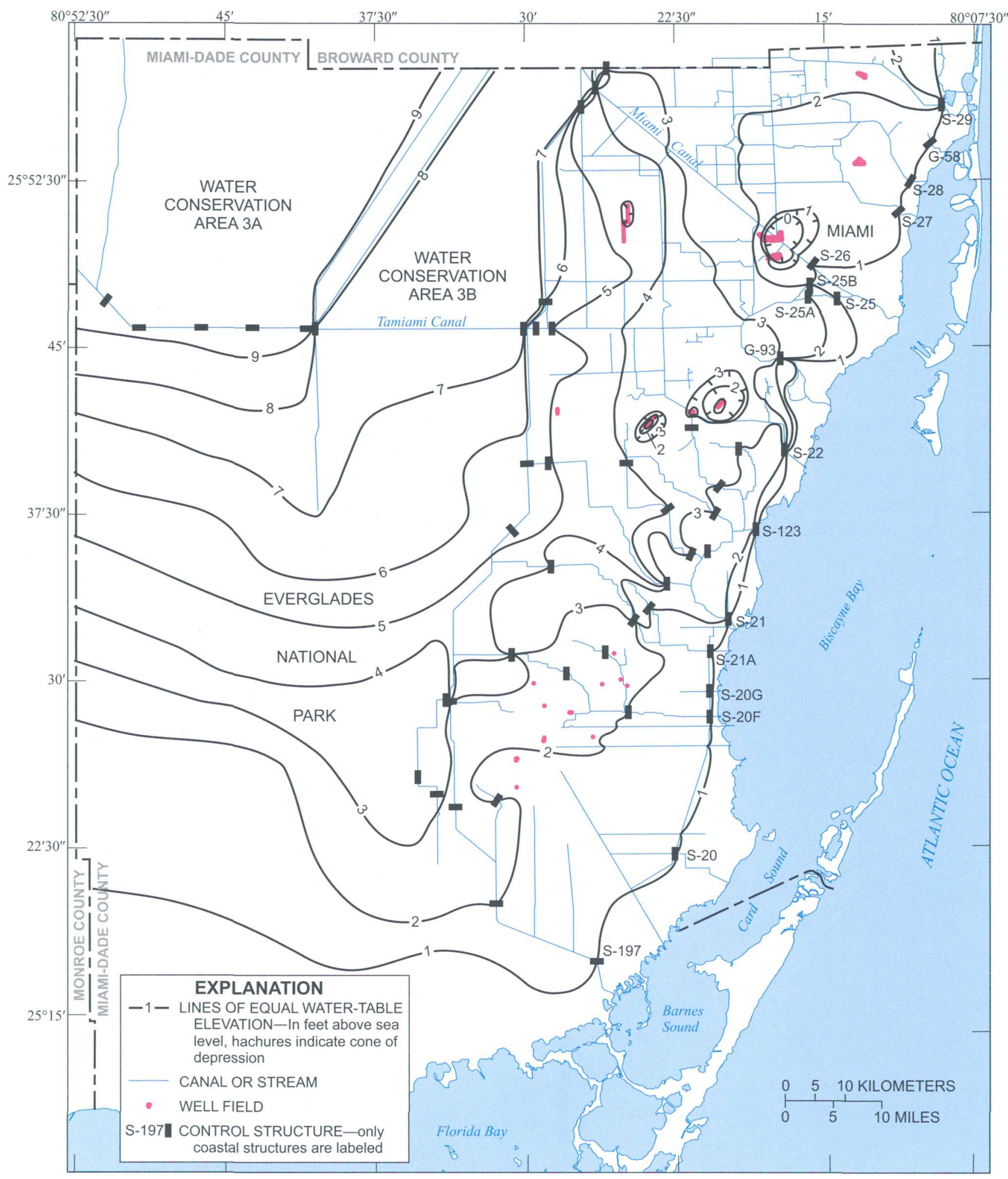

Figure 4. Water-table elevation for May 1993, Miami-Dade County, Florida (from Sonenshein and Koszalka, 1996). 


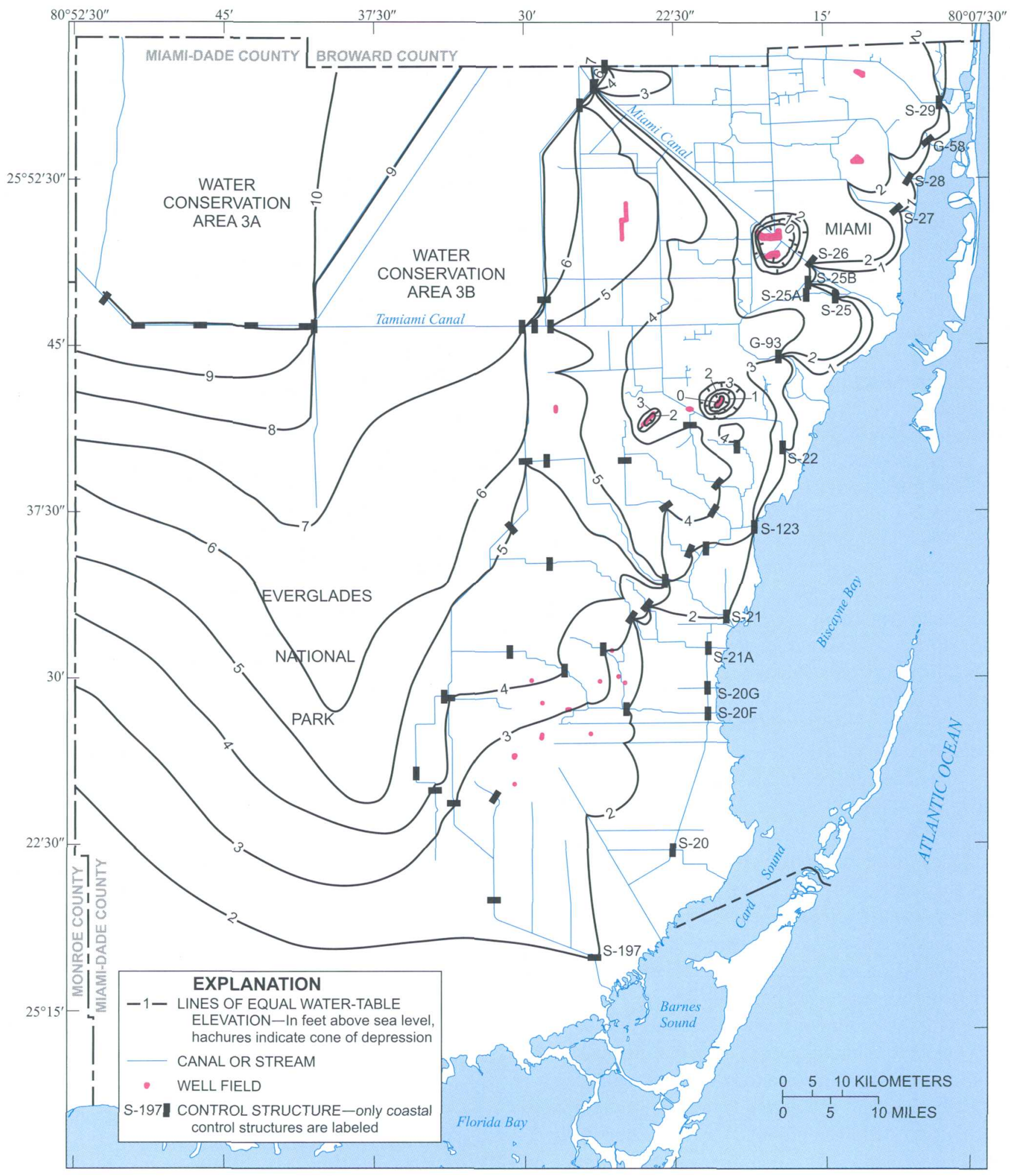

Figure 5. Water-table elevation for November 1993, Miami-Dade County, Florida (from Sonenshein and Koszalka, 1996). 
the numerical model of ground-water flow is essential to adequately simulate ground-water discharge to Biscayne Bay.

Control structures located within most of the canals are used to manage the water resources of southeastern Florida (figs. 4 and 5). During the wet season, coastal control structures periodically open and allow discharge of surface water to Biscayne Bay. During the dry season, the coastal control structures generally remain closed to maintain relatively high water levels along the coast. Large differences in stage are commonly observed across the control structures. These stage differences likely cause ground-water flow around the structures, but there has been little research to quantify actual flow rates.

\section{Ground-Water Withdrawals}

Ground-water withdrawals from the Biscayne aquifer are the sole source of drinking water and the primary source of irrigation water for agriculture in Miami-Dade County. Near the major municipal well fields, the effects of pumping can be seen as localized depressions in the water-table surface (figs. 4 and 5). In some cases, the inland movement of the saltwater interface is attributed to lowered water levels that result from pumping. Total well-field withdrawals from the Biscayne aquifer were calculated by combining the pumping rates from the municipal well fields in Miami-Dade County. Withdrawal totals range from $1.0 \times 10^{6}$ to $1.5 \times 10^{6} \mathrm{~m}^{3} / \mathrm{d}$ from January 1989 to September 1998, and do not show seasonal
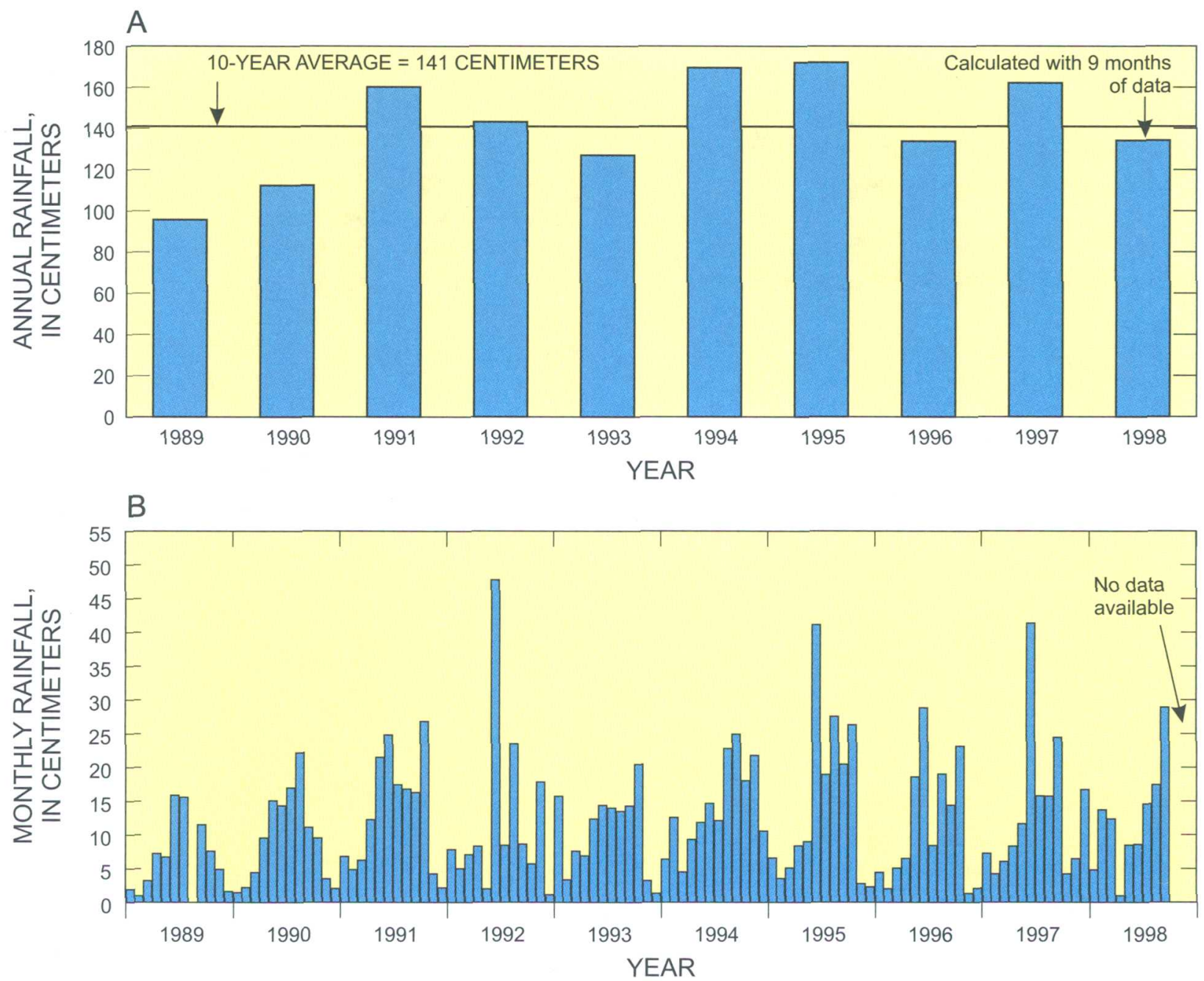

Figure 6. Totals of (A) annual and (B) monthly rainfall, 1989-98. Rainfall totals calculated for domain of regional-scale model using Thiessen polygons of rainfall monitoring stations. 


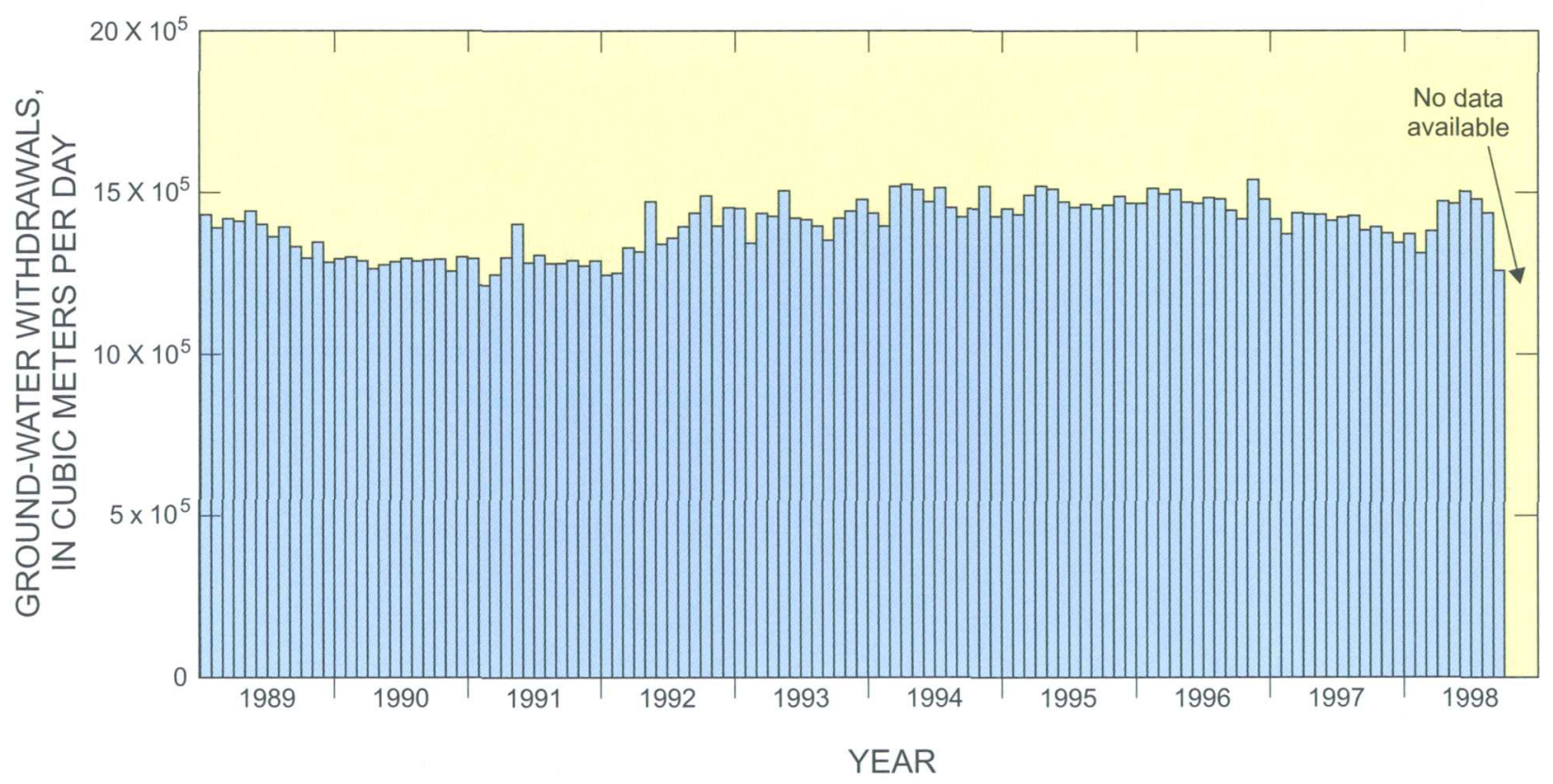

Figure 7. Municipal well-field withdrawals from the Biscayne aquifer in Miami-Dade County from January 1989 to September 1998.

fluctuations (fig. 7). Ground-water withdrawals for agricultural purposes, while substantial, have not been quantified for Miami-Dade County.

\section{Freshwater-Saltwater Transition Zone}

Parker and others (1955), Kohout (1960a, 1964), and many other investigators have shown that ground-water flow is affected by differences in ground-water density. In coastal settings, there are variations in ground-water density because the density of seawater is 2.5 percent higher than the density of freshwater. As fresh ground water flows toward the coast, it meets saline ground water that originated from the ocean, and the density differences affect the ground-water flow paths. Kohout $(1960 a, 1964)$ studied coastal ground-water flow by installing numerous monitoring wells along a transect perpendicular to the coast in the Cutler Ridge area (near Miami) of southeastern Florida. He used chloride concentration as a proxy for salinity and fluid density. A cross section showing lines of equal chloride concentration for September 18, 1958, indicates that a tongue of relatively dense, saline ground water extended inland from the coast at the base of the Biscayne aquifer (fig. 8). The cross section also indicates no apparent sharp interface between fresh and saline ground water; instead, the saltwater interface was a broad transition zone.

To illustrate the effects of the saltwater interface on ground-water flow, Kohout (1964) performed a flow-net analysis (fig. 8) that shows fresh ground water mixing with saline ground water as it discharges to Biscayne Bay. From this analysis, Kohout (1964) estimated that about 12.5 percent of the ground water discharged to Biscayne Bay was recirculated seawater. By linearly extending the zero horizontal gradient line, which marks the location where all ground-water flow is vertically upward (fig. 8), it appears that all groundwater discharge occurred within about $130 \mathrm{~m}$ of the shore.

Contours of ground-water salinity also were prepared by Kohout (1964) for the Silver Bluff area (near Miami) for data collected on November 2, 1954 (fig. 9). At Silver Bluff, the saltwater tongue extended inland from the coast about $3.7 \mathrm{~km}$, more than $3 \mathrm{~km}$ farther than at Cutler Ridge.

Results from the ground-water sampling performed as part of this study are shown in table 2 . Monthly measurements of specific conductance were converted to chloride concentrations using the relation established earlier in this report. Average values of chloride concentration, which were calculated from the monthly values of chloride concentration from March 1998 to February 1999, range from 30 to $19,470 \mathrm{mg} / \mathrm{L}$. During the period from March 1998 to 


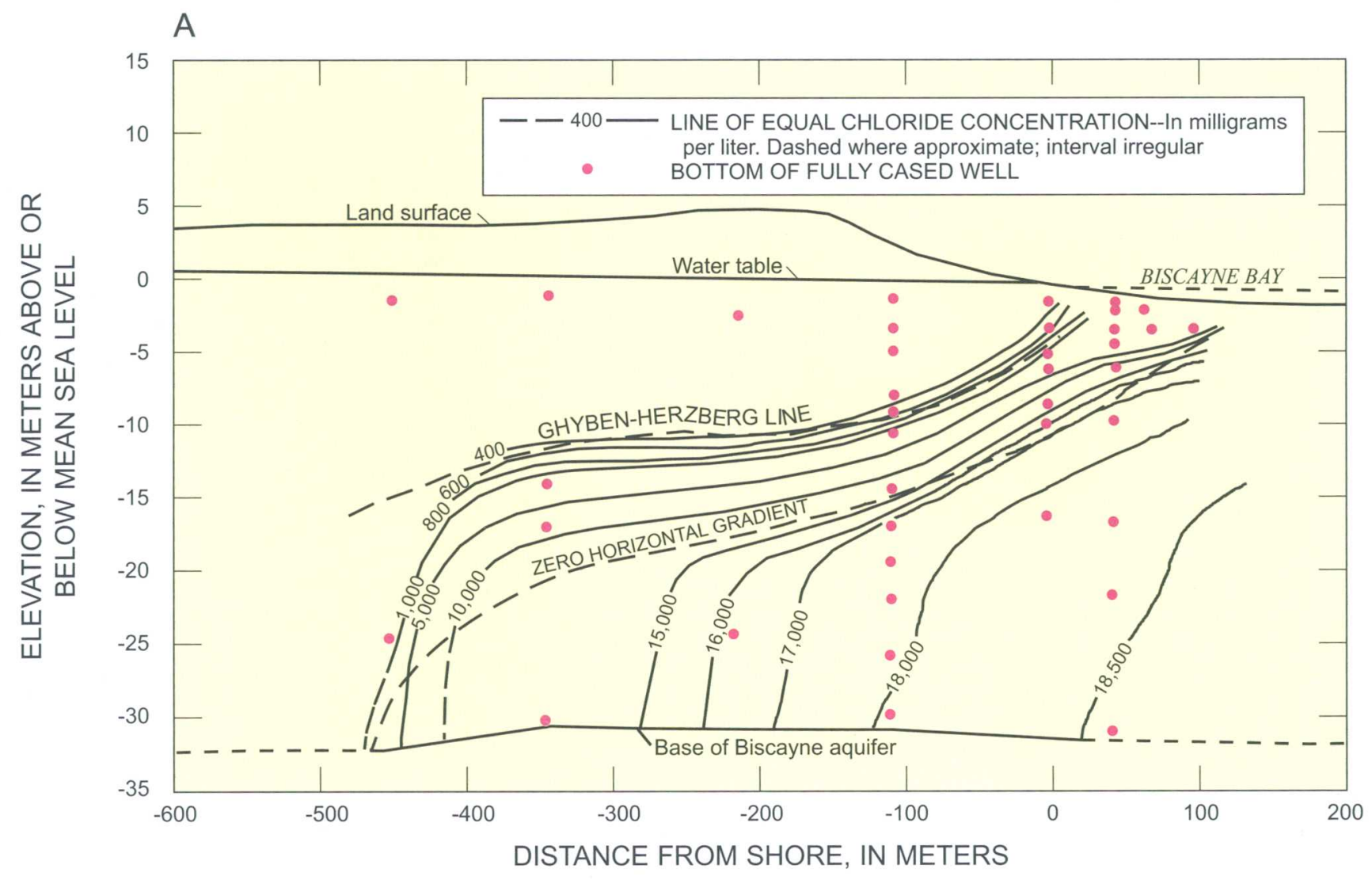

B

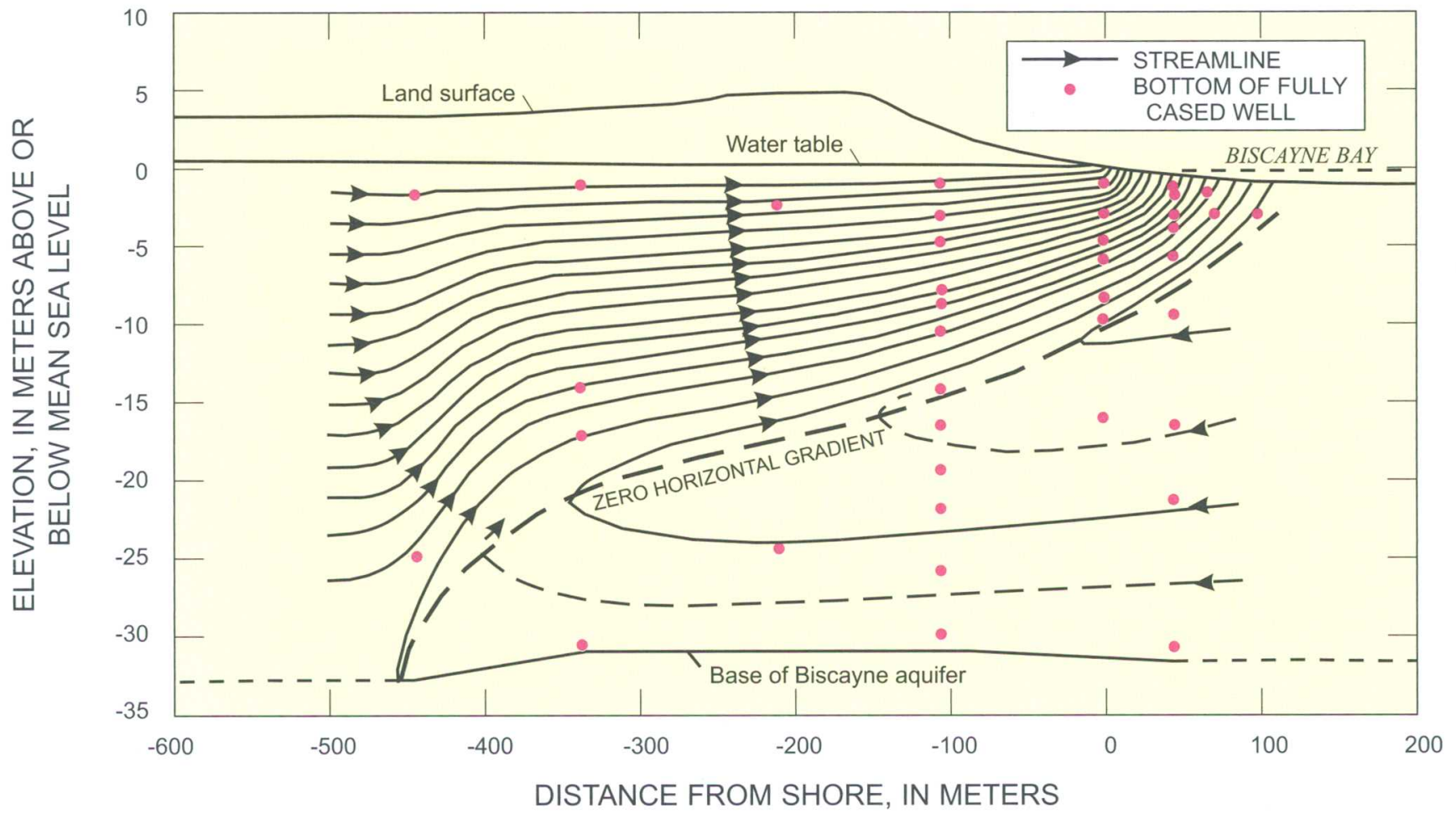

Figure 8. Lines of equal chloride concentration (A) and results from a flow-net analysis (B) for the Cutler Ridge area, September 18, 1958 (modified from Kohout, 1964). 


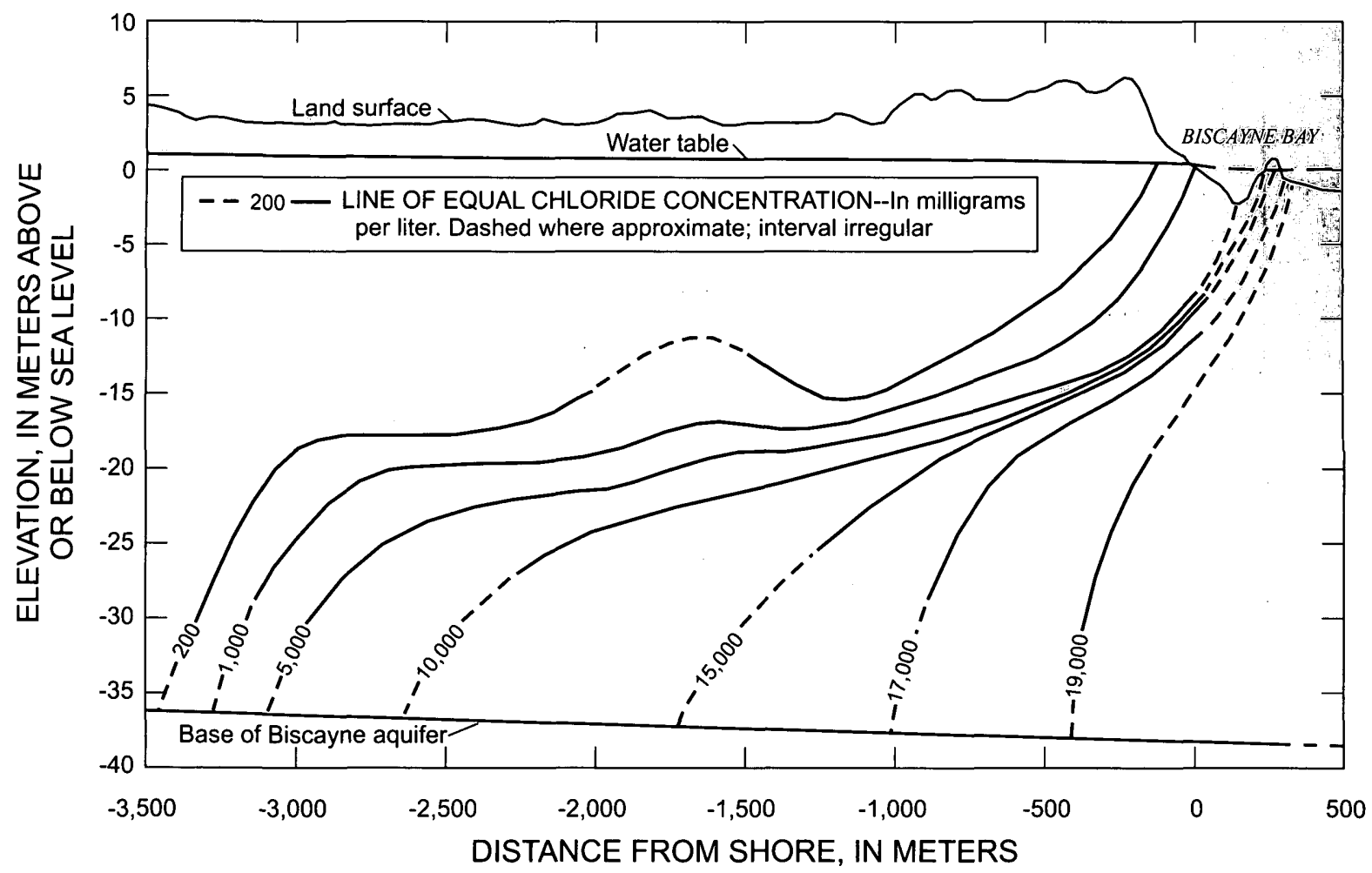

Figure 9. Lines of equal chloride concentration for the Silver Bluff area, November 2, 1954 (modified from Kohout, 1964).

February 1999, the maximum range in chloride concentration $(5,556 \mathrm{mg} / \mathrm{L})$ was observed at G-3755. The observed range in chloride concentration for the remaining wells sampled during this period did not exceed $2,669 \mathrm{mg} / \mathrm{L}$.

The chloride concentration of Biscayne Bay water may affect the chloride concentrations in the aquifer beneath Biscayne Bay. Chloride concentrations in the bay, however, are not continuously measured at the three transects. For this reason, the results from a hydrodynamic circulation model (John Wang, University of Miami, written commun., 2000), which simulates the period from January 1995 to December 1998 , may provide insight into the temporal variation in chloride concentration at the three transects. The finite-element model has a spatial resolution of about $500 \mathrm{~m}$, which means that simulated concentrations are representative within about $250 \mathrm{~m}$ of shore, but the concentrations are probably representative up to about $1,000 \mathrm{~m}$. The relation between salinity and chloride concentration, as previously discussed, was used to convert simulated values of salinity to simulated values of chloride concentration. For the 4-year period simulated by the hydrodynamic circulation model, average values of chloride concentration at the
Coconut Grove, Deering Estate, and Mowry Canal transects are $18,200,16,200$, and $12,400 \mathrm{mg} / \mathrm{L}$, respectively. The ranges of simulated chloride concentration for the Coconut Grove, Deering Estate, and Mowry Canal transects are 8,000,14,900, and 17,500 $\mathrm{mg} / \mathrm{L}$, respectively.

Ground-water salinity data (table 2 ) and results from the TDEM soundings (table 3) were used to construct plots showing lines of equal chloride concentration for the Coconut Grove, Deering Estate, and Mowry Canal transects (figs. 1 and 10). At Coconut Grove, the saltwater tongue appears to extend at least $4 \mathrm{~km}$ inland from the coast, although there is not enough field data to adequately characterize the inland portion of the transition zone (fig. 10). Offshore, the chloride data for Coconut Grove suggest that ground water discharges to the bay. A monitoring well (G-3654) just offshore has an average chloride concentration of $11,670 \mathrm{mg} / \mathrm{L}$ (table 2). Farther offshore, however, the monitoring wells have chloride concentrations similar to the average chloride concentration in the bay. This suggests that most fresh ground-water discharge at the Coconut Grove transect occurs within the first $300 \mathrm{~m}$ of the shoreline. 


\begin{tabular}{|c|c|c|c|c|c|}
\hline \multicolumn{6}{|c|}{$\begin{array}{l}\text { [Distances along transect are relative to the shoreline; positive distances are offshore, negative distances are inland. Average chloride } \\
\text { concentrations and average salinity values were calculated with monthly data collected from March } 1998 \text { to February 1999] }\end{array}$} \\
\hline $\begin{array}{c}\text { Well } \\
\text { identification }\end{array}$ & $\begin{array}{l}\text { Distance } \\
\text { along } \\
\text { transect } \\
\text { (meters) }\end{array}$ & $\begin{array}{c}\text { Elevation } \\
\text { of screen } \\
\text { center } \\
\text { (meters) }\end{array}$ & $\begin{array}{c}\text { Average } \\
\text { chloride } \\
\text { concentration } \\
\text { (milligrams } \\
\text { per liter) }\end{array}$ & $\begin{array}{c}\text { Observed range in } \\
\text { chloride } \\
\text { concentration } \\
\text { (milligrams } \\
\text { per liter) }\end{array}$ & $\begin{array}{c}\text { Average } \\
\text { salinity } \\
\text { (kilograms per } \\
\text { cubic meter) }\end{array}$ \\
\hline \multicolumn{6}{|c|}{ Coconut Grove transect } \\
\hline G-3229 & -4000 & -23.0 & 675 & 500 & 1 \\
\hline G-3750 & -50 & -28.5 & 18,810 & 373 & 33 \\
\hline G-3654 & 62 & -6.3 & 11,670 & 146 & 20 \\
\hline G-3656 & 301 & -11.5 & 17,320 & 631 & 31 \\
\hline G-3657 & 301 & -3.8 & 16,680 & 700 & 29 \\
\hline G-3659 & 512 & -3.7 & 16,050 & 503 & 28 \\
\hline G-3747 & -572 & -24.3 & 18,480 & 471 & 32 \\
\hline G-3748 & -50 & -9.3 & 4,530 & 1,327 & 8 \\
\hline G-3749 & -50 & -17.9 & 17,730 & 602 & 31 \\
\hline \multicolumn{6}{|c|}{ Deering Estate transect } \\
\hline G-906 & -107 & -28.6 & 18,080 & 1,493 & 32 \\
\hline G-911 & -107 & -13.9 & 2,050 & 989 & 4 \\
\hline G-912 & -107 & -8.5 & 170 & 0 & 1 \\
\hline G-913 & -107 & -7.5 & 130 & 0 & 1 \\
\hline G-916 & -107 & -.7 & 30 & 0 & 0 \\
\hline G-929 & -2 & -2.7 & 240 & 2,020 & 1 \\
\hline G-930 & -2 & -5.8 & 1,200 & 2,669 & 2 \\
\hline G-931 & -2 & -8.3 & 5,750 & 0 & 10 \\
\hline G-939 & -400 & -14.2 & 1,400 & 200 & 3 \\
\hline G-3611 & $-847^{\circ}$ & -28.0 & 200 & 40 & 1 \\
\hline G-3646 & 113 & -8.0 & 15,590 & 1,592 & 27 \\
\hline G-3647 & 113 & -2.0 & 3,810 & 159 & 7 \\
\hline G-3648 & 297 & -5.8 & 14,810 & 308 & 26 \\
\hline G-3649 & 296 & -2.9 & 13,830 & 536 & 24 \\
\hline G-3650 & 525 & -5.5 & 17,480 & 963 & 31 \\
\hline G-3651 & 527 & -2.8 & 15,720 & 341 & 28 \\
\hline G-3652 & 975 & -5.6 & 19,380 & 0 & 34 \\
\hline G-3751 & -35 & -1.9 & 280 & 168 & 1 \\
\hline G-3752 & -35 & -14.7 & 17,580 & 1,327 & 31 \\
\hline G-3753 & -35 & -27.1 & 17,870 & 1,095 & 32 \\
\hline G-3754 & -35 & -5.9 & 200 & 0 & 1 \\
\hline G-3755 & -263 & -25.7 & 12,400 & 22 & 22 \\
\hline \multicolumn{6}{|c|}{ Mowry Canal transect } \\
\hline G-3629 & 33 & -12.0 & 18,825 & 799 & 33 \\
\hline G-3631 & 265 & -7.0 & 19,140 & 341 & 34 \\
\hline G-3632 & 265 & -4.0 & 18,265 & 897 & 32 \\
\hline G-3634 & 490 & -6.5 & 19,230 & 341 & 34 \\
\hline G-3635 & 490 & -3.75 & 17,870 & 766 & 32 \\
\hline G-3636 & 750 & -7.0 & 19,305 & 341 & 34 \\
\hline G-3637 & 750 & -4.0 & 18,380 & 211 & 33 \\
\hline G-3638 & 35 & -6.5 & 11,775 & 1,293 & 21 \\
\hline G-3639 & 35 & -3.0 & 9,195 & 373 & 16 \\
\hline G-3756 & -601 & -26.0 & 19,470 & 1,062 & 34 \\
\hline G-3757 & -604 & -17.5 & 18,850 & 1,194 & 33 \\
\hline G-3758 & -608 & -7.0 & 595 & 972 & 1 \\
\hline G-3759 & $-3,000$ & -27.0 & 11,340 & 963 & 20 \\
\hline
\end{tabular}


Table 3. Results from the time-domain electromagnetic (TDEM) soundings near Mowry Canal

\begin{tabular}{|c|c|c|c|c|c|c|}
\hline $\begin{array}{c}\text { Electromagnetto } \\
\text { sounding }\end{array}$ & Latflude & Longfitude & Date & $\begin{array}{l}\text { Approxtimate } \\
\text { distance from } \\
\text { coastline } \\
\text { (ineters) }\end{array}$ & $\begin{array}{l}\text { Approxtmate } \\
\text { elevation of low } \\
\text { resistlvity layer } \\
\text { (meters) }\end{array}$ & $\begin{array}{l}\text { liesistivtty } \\
\text { ((ohm=meters) }\end{array}$ \\
\hline TDEM-5 & $25^{\circ} 28^{\prime} 27^{\prime \prime}$ & $80^{\circ} 22^{\prime} 17^{\prime \prime}$ & $05-10-97$ & 3,100 & -13.5 & 2.5 \\
\hline MEN & & 8022328 & $05-10=9$ & & -150 & 2.8 \\
\hline TDEM-8 & $25^{\circ} 28^{\prime} 13^{\prime \prime}$ & $80^{\circ} 24^{\prime} 16^{\prime \prime}$ & $05-10-97$ & 6,300 & -17.0 & 8 \\
\hline MDEM & & & & & & \\
\hline TDEM-10 & $25^{\circ} 28^{\prime} 13^{\prime \prime}$ & $80^{\circ} 24^{\prime} 23^{\prime \prime}$ & $05-28-97$ & 6,600 & -18.5 & 20 \\
\hline & & 12 & & & & \\
\hline TDEM-R & $25^{\circ} 28^{\prime} 20^{\prime \prime}$ & $80^{\circ} 23^{\prime} 49^{\prime \prime}$ & $09-21-95$ & 5,700 & -12.5 & 9 \\
\hline
\end{tabular}

At Deering Estate, the inland extent of the saltwater tongue is less than $1 \mathrm{~km}$ from the coast. Offshore data indicate that fresh ground water is discharging to the bay because measured chloride concentrations beneath the bay are less than the average chloride concentration of the bay (fig. 10). A shallow monitoring well (G-3647) about $100 \mathrm{~m}$ offshore has a chloride concentration of about $3,810 \mathrm{mg} / \mathrm{L}$ (table 2), which suggests that brackish ground water is discharging to the bay $100 \mathrm{~m}$ from shore. The chloride data for Deering Estate also suggest that most fresh ground-water discharge to the bay occurs within about $500 \mathrm{~m}$ from shore (fig. 10).

At Mowry Canal, TDEM soundings were used to help determine the inland extent of the saltwater tongue. Resistivity values less than $10 \mathrm{ohm}-\mathrm{m}$ (ohmmeters) typically are considered indicative of saline ground water; however, the exact concentration cannot be determined from this method. Based on this assumption, the saltwater tongue extends inland about $6 \mathrm{~km}$ (fig. 10). Of the three transects, the chloride data suggest that Mowry Canal has the least amount of ground-water discharge to the bay, because chloride concentrations in the aquifer exceed $18,000 \mathrm{mg} / \mathrm{L}$ at distances of only $300 \mathrm{~m}$ from shore. Near shore, however, there is some fresh ground-water discharge to the bay; a chloride concentration of $9,195 \mathrm{mg} / \mathrm{L}$ was measured in a shallow well (G-3639) about $35 \mathrm{~m}$ from shore.

When drawn on a map, the inland extent of the saltwater interface at the base of the Biscayne aquifer is referred to as the saltwater intrusion line. In an effort to protect ground-water resources in Miami-Dade
County, the saltwater intrusion line is periodically located and mapped. Parker and others (1955) provide a thorough description of how saltwater in the aquifer migrated inland in response to the draining of the Everglades. More recently, the 1984 position of the saltwater intrusion line was mapped by Klein and Waller (1985). Later, Sonenshein (1997) used data from monitoring wells and TDEM to map the position of the saltwater intrusion line. Fitterman and DeszczPan (1998) used airborne geophysical methods to map the position of the saltwater intrusion line for southern Miami-Dade County. These three data sources are combined in figure 11 to illustrate the inland extent of the transition zone. Differences between saltwater intrusion lines do not necessarily indicate movement of the saltwater interface; differences between saltwater intrusion lines may be the result of interpretation of different data sources. Also included in figure 11 is the saltwater intrusion line predicted by the GhybenHerzberg relation (Konikow and Reilly, 1999). The Ghyben-Herzberg relation is based on the balance of forces for a static ground-water system that is composed of fresh ground water overlying saline ground water. The relation states that the depth to the interface between fresh and saline ground water will be at a depth equal to 40 times the freshwater head value. For many areas, the Ghyben-Herzberg relation is a good indicator of the position of the saltwater intrusion line; however, for northern and southern Miami-Dade County, figure 11 suggests that the Ghyben-Herzberg relation is not valid, because it suggests that the interface should be located up to 10 kilometers inland of the observed saltwater intrusion line. 

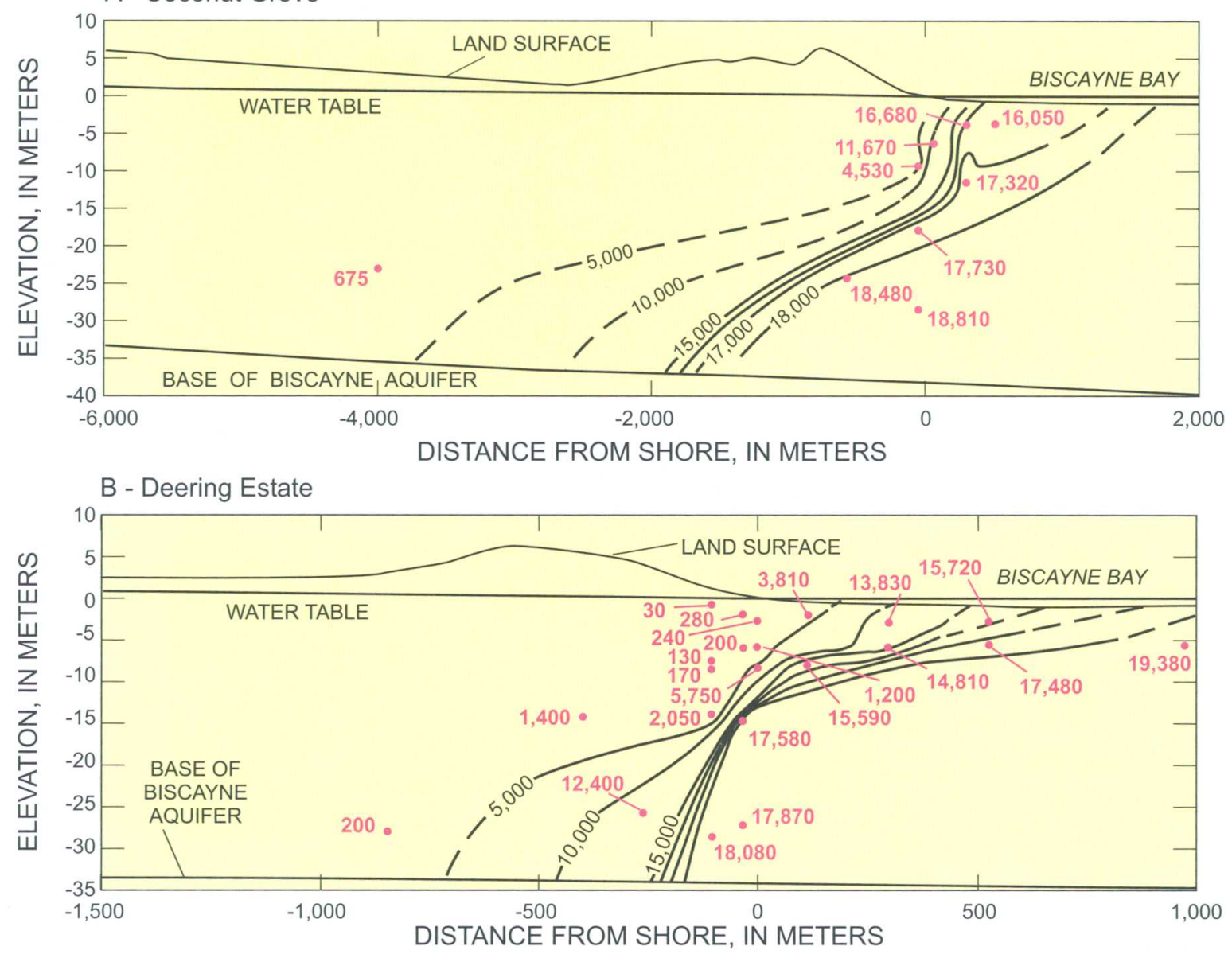

C - Mowry Canal

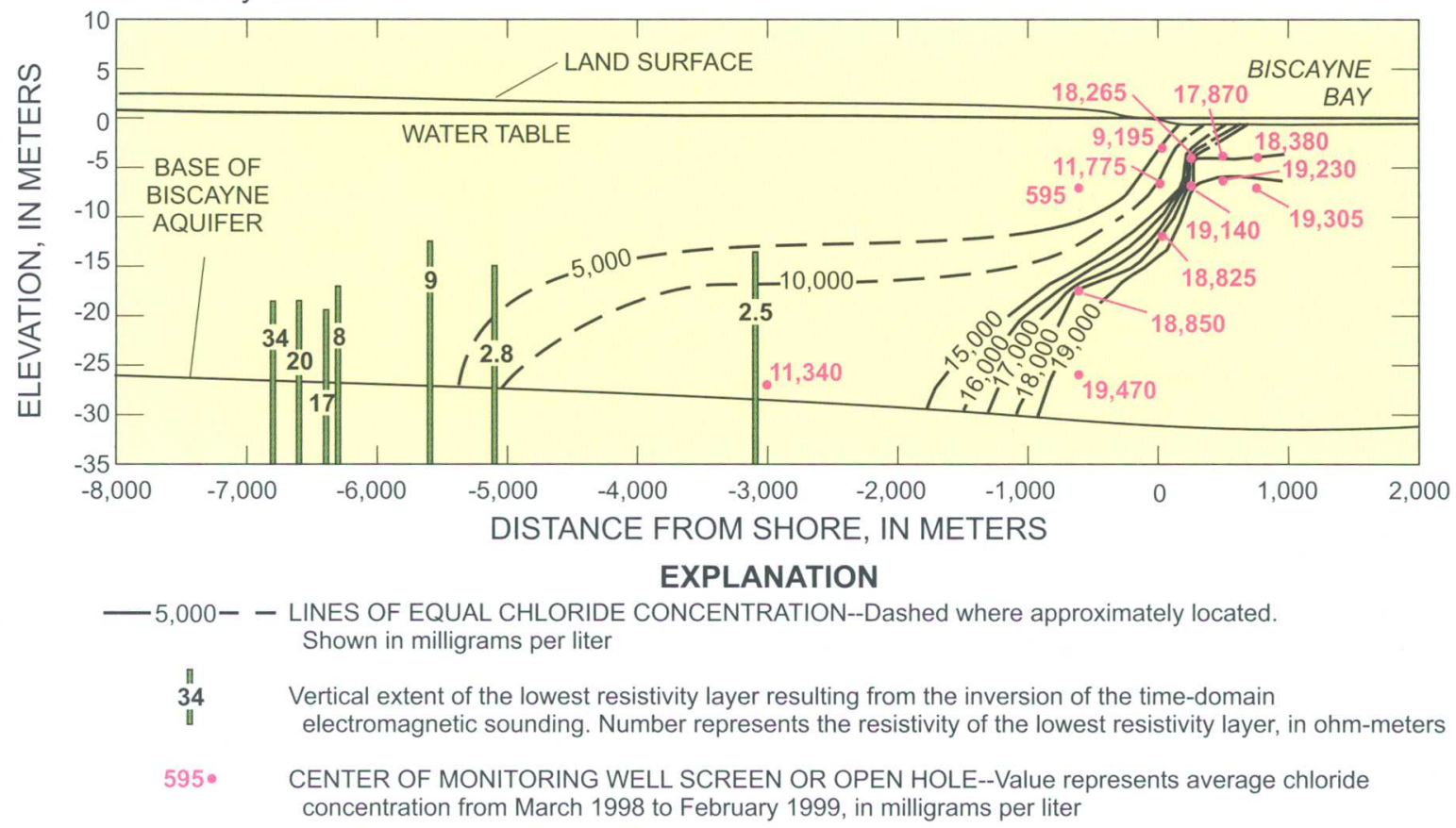

Figure 10. Lines of equal chloride concentration from March 1998 to February 1999 for the (A) Coconut Grove, (B) Deering Estate, and (C) Mowry Canal transects. 


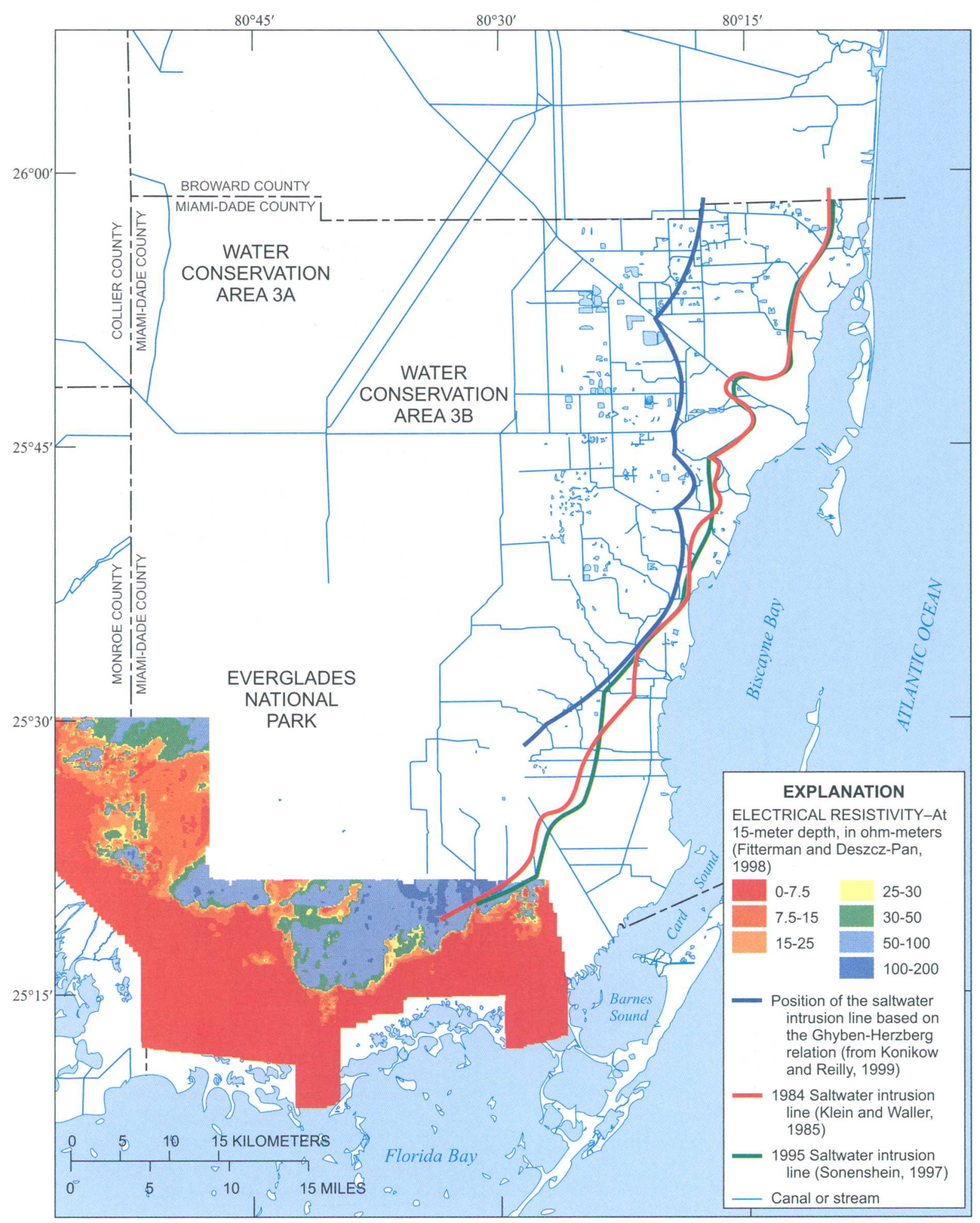

Figure 11. Location of saltwater intrusion lines in southern Florida based on previous studies, the GhybenHerzberg relation, and a geophysical survey. Differences in line location do not necessarily indicate movement of the saltwater intrusion line; differences may be due to interpretation, method, or data availability. 


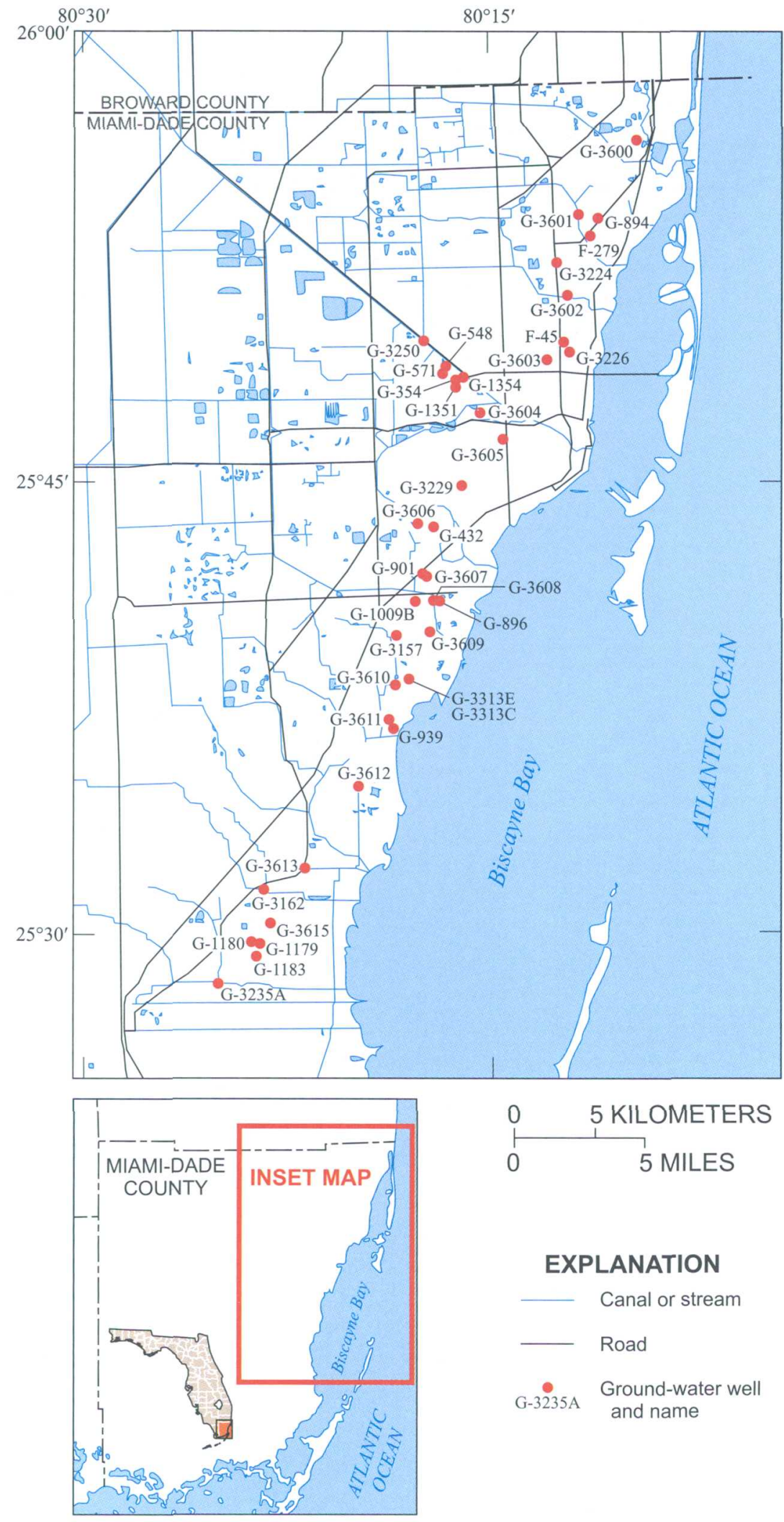

Figure 12. Ground-water monitoring wells in the Biscayne aquifer used to monitor the location of the saltwater intrusion line in Miami-Dade County.
Parker and others (1955) described how anthropogenic changes have affected the position of the saltwater intrusion line. Today, the saltwater intrusion line is carefully monitored by a salinity-monitoring network (fig. 12), consisting of ground-water monitoring wells located on or near the saltwater intrusion line. A list of these monitoring wells is given in appendix III. Plots of chloride concentration relative to time were evaluated for each salinity-monitoring well to identify any long-term changes in the saltwater intrusion line that could have affected rates of fresh ground-water discharge to Biscayne Bay from 1989 to 1998 . For most of the plots, which use a logarithmic axis for chloride concentration, there was no discernible trend in chloride concentration. Temporal plots of chloride concentration for the five wells that showed substantial changes in chloride concentration are shown in figure 13. Although wells G-432 and G-901 show increased chloride concentrations over time, concentrations tended to stabilize between 1,000 and $2,000 \mathrm{mg} / \mathrm{L}$, suggesting the saltwater intrusion line moved slightly inland at both wells. A westward movement of the saltwater interface also could correspond with a decrease in ground-water discharge to Biscayne Bay. Based on this temporal analysis of chloride concentrations, it seems that the position of the saltwater intrusion line, for the most part, did not appreciably change. This observation is used later in the report to support development of the regional-scale ground-water flow model.

Darcy's law states that ground-water flow is linearly proportional to the hydraulic gradient, which means that ground-water flow to Biscayne Bay is affected by the 


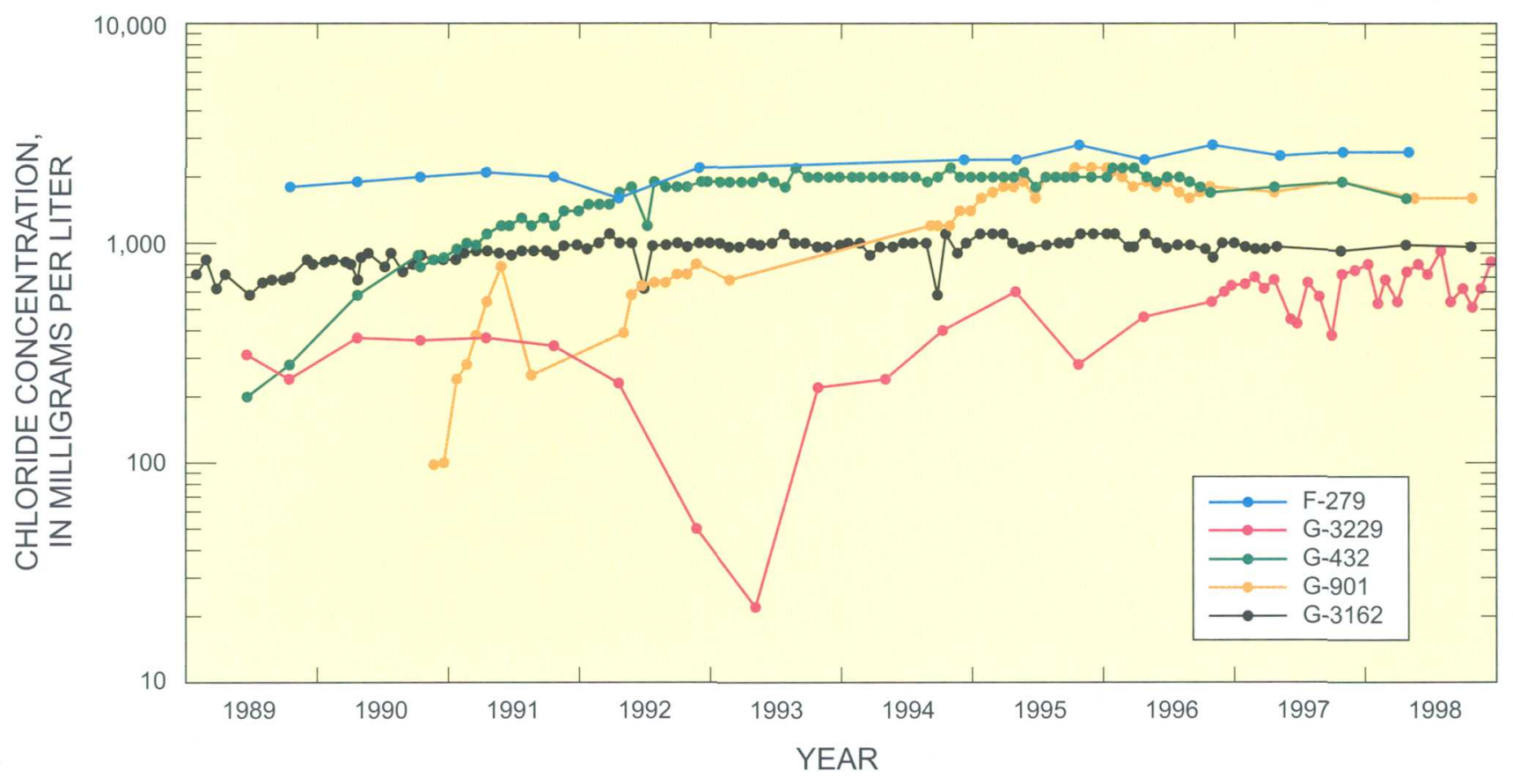

Figure 13. Chloride concentrations relative to time for selected monitoring wells in Miami-Dade County.

water-table elevation and the stage in the bay. Average values of hourly, daily, and monthly stage for Biscayne Bay are shown in figure 14. The average stage values were calculated using the downstream monitoring station at structure S-123 (figs. 4 and 5), which is located less than $1 \mathrm{~km}$ from the coast and in the central part of the study area. To ensure that the downstream stage values are not significantly affected by canal discharges or other potential influences, tide data from the Virginia Key station (fig. 1) also are included in figure 14 and the records match. Figure 14 suggests that the stage of Biscayne Bay can greatly affect ground-water discharge. Over a 12-month period, the average monthly stage of the bay can change by $0.4 \mathrm{~m}$, as was the case in 1992. This is a considerable change considering that the range in the water-table elevations is about $3 \mathrm{~m}$ over the study area. Average daily stages and hourly stages also exhibit fluctuations up to $0.4 \mathrm{~m}$, which may also affect ground-water discharge over shorter time periods.

\section{SIMULATION OF GROUND-WATER DISCHARGE TO BISCAYNE BAY}

The simulation of ground-water discharge to Biscayne Bay was performed at the local and regional scales. Two local-scale models were developed in cross section to simulate the complex ground-water flow patterns near the coast of Biscayne Bay. With the assumption of steady-state conditions, the cross section models were calibrated using ground-water data collected as part of this study. Results from the crosssectional models were then used to aid the development of the larger, regional-scale model and provide a detailed spatial representation of the ground-water discharge patterns. The regional-scale model simulates transient ground-water discharge to Biscayne Bay in three dimensions. The regional-scale model was developed and calibrated using field data for an approximate 10-year period from January 1989 to September 1998.

The cross-sectional and regional-scale numerical models were developed using the conceptual hydrologic model shown in figure 15 , which is a simplified representation of the actual system. Recharge to the Biscayne aquifer is assumed instantaneous, meaning that the unsaturated zone is not explicitly represented. Another assumption is that the Biscayne aquifer can be simulated with an equivalent porous medium (EPM). Historical observations suggest that isolated, submerged ground-water springs were once found within Biscayne Bay. By using the assumption of an EPM, individual springs and conduits are not explicitly simulated, but rather the 

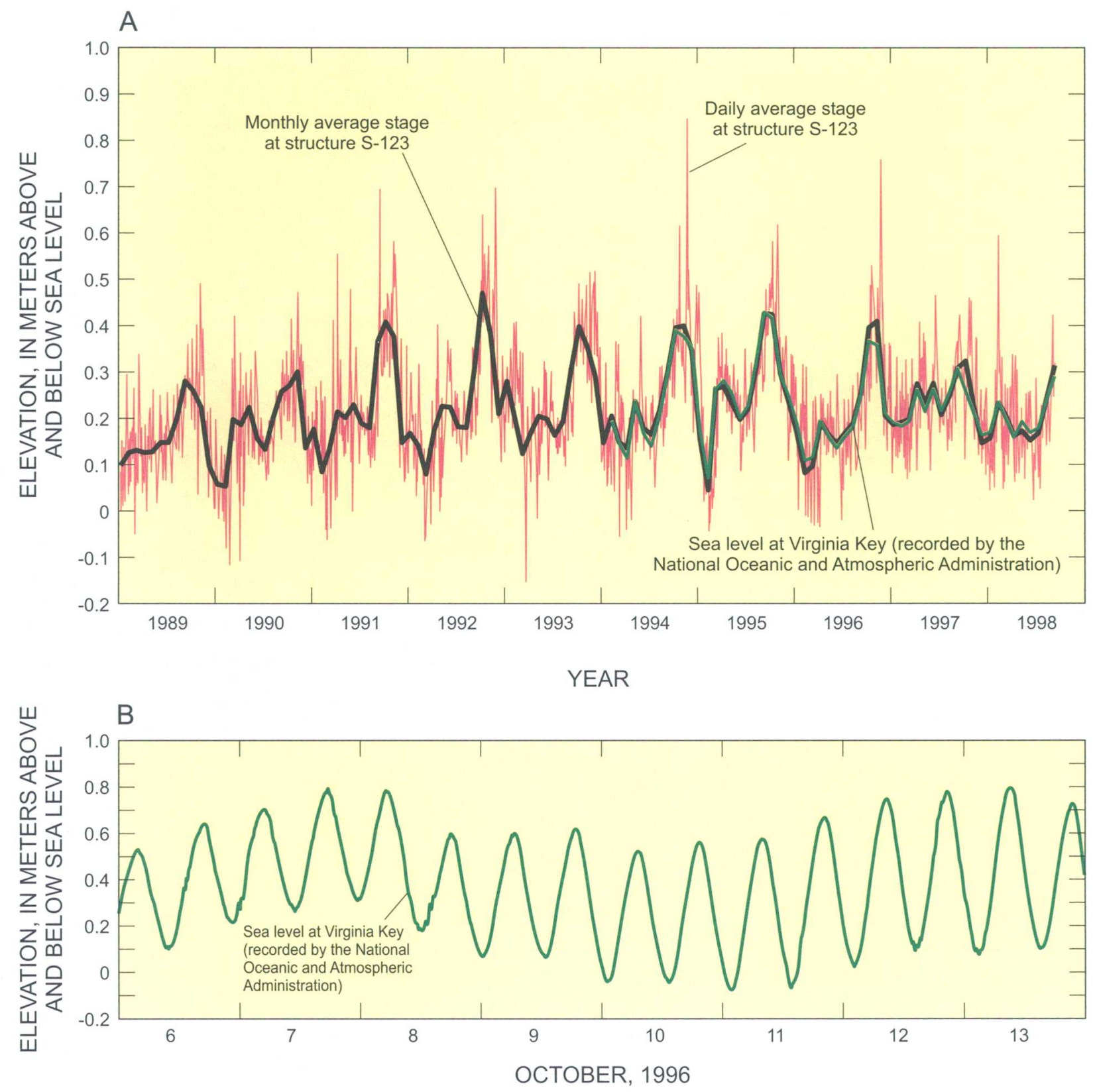

Figure 14. Stage fluctuations in Biscayne Bay, Florida, 1989-99, plotted as (A) average daily and monthly averages and $(B)$ hourly values.

properties of the conduit are averaged within model cells. This assumption limits the interpretation of model results at local scales, but is thought to be appropriate when conduits or fractures are much smaller than the scale of the model.

The numerical models were calibrated to field data to ensure that they are reasonable representations of the physical system. Calibration is a subjective process that requires altering the parameters of the numer- ical model until model results compare with field observations. This process is sometimes referred to as "solving the inverse problem." When an acceptable match between simulated results and field observations is obtained and realistic aquifer parameters are used in the model, it is assumed that the model is a reasonable representation of the physical system. Solving the inverse problem is complicated because more than one set of model parameters can produce an equally 


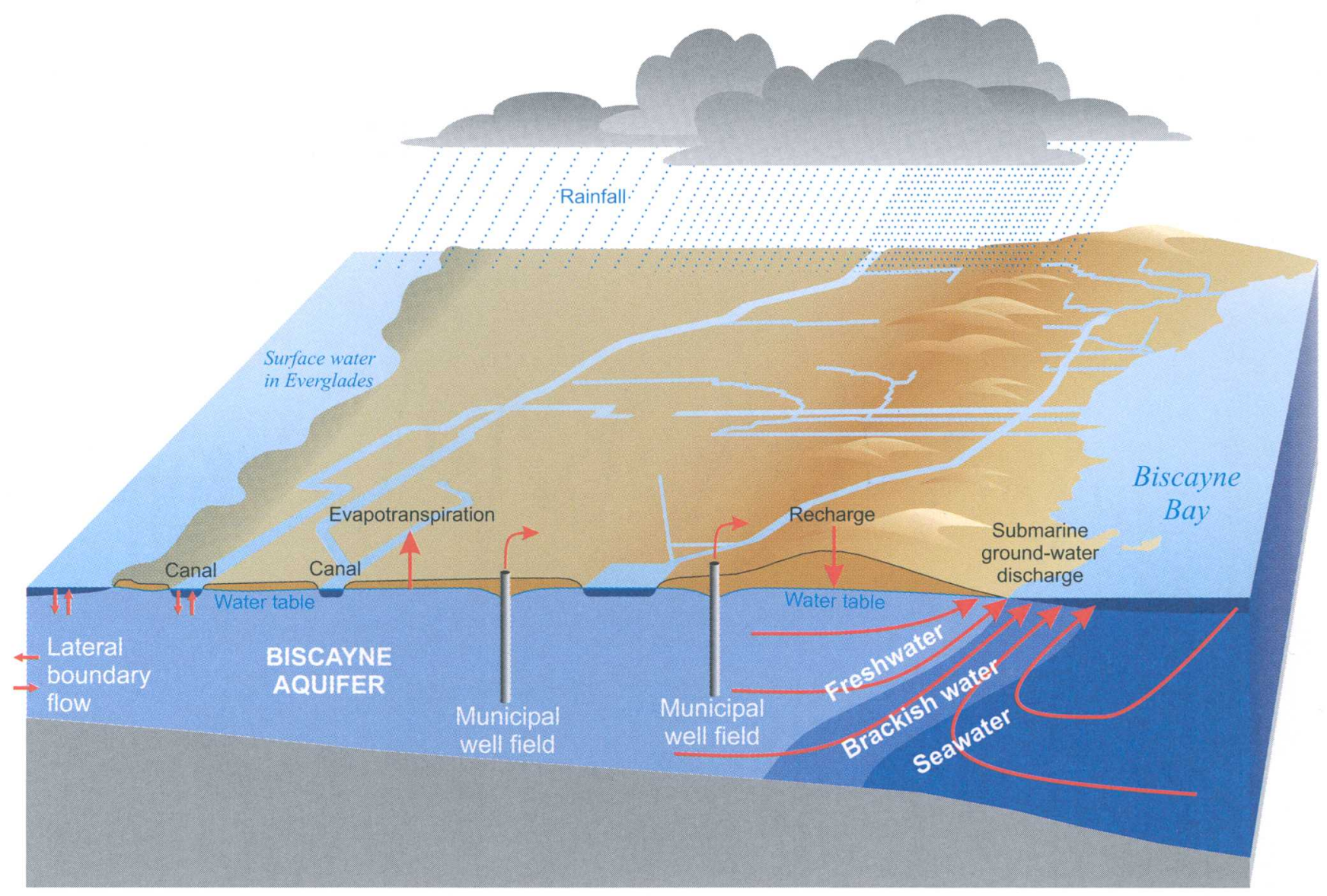

Figure 15. Conceptual hydrologic model used to develop numerical models of ground-water flow.

well calibrated model. To minimize the potential for this problem, the simplest spatial distribution of model parameters was used to calibrate the numerical models.

During the initial phases of the numerical modeling, several different codes were evaluated to determine their effectiveness in achieving project objectives and simulating the complex variabledensity flow patterns observed in the Biscayne aquifer. For example, the HST3D code (Kipp, 1997) accurately simulated flow in cross section; however, because of numerical dispersion, this code did not accurately simulate flow at the regional scale. The SUTRA code (Voss, 1984) also was successfully used for preliminary cross-sectional models, but a threedimensional version of the code was not available at the time. Eventually a relatively new code, SEAWAT (Guo and Bennett, 1998), was selected for the study because preliminary results indicated that the code: (1) accurately simulated variable-density flow, (2) had acceptable options for minimizing numerical dispersion, and (3) read standard MODFLOW and MT3D data sets, which are easily created. The original version of SEAWAT was modified as part of this study to improve functionality and simulation accuracy (Langevin and Guo, 1999).

\section{Governing Equations}

Simulation of ground-water flow is performed by numerically solving the ground-water flow and solute-transport equations. The ground-water flow equation can take many forms depending on the assumptions that are valid for the problem of interest. In most cases, it is assumed that the density of ground water is spatially and temporally constant. To simulate ground-water flow in coastal environments, the assumption of constant density is not valid because seawater contains a higher concentration of dissolved salts than rainfall, which is the primary source for 
aquifer recharge. As previously discussed, fluid density is a function of dissolved salt. Kohout (1960a) and many other investigators have shown that the density difference between fresh ground water and seawater can greatly affect ground-water flow patterns. Accordingly, the ground-water flow equation used in the present study does not assume that ground-water density is constant. A general form of the equation that describes the flow of variable-density ground water is:

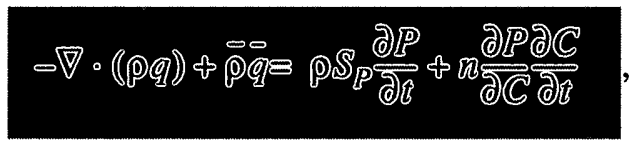

where:

$\nabla$ is the spatial gradient operator,

$\rho$ is fluid density $\left[\mathrm{M} / \mathrm{L}^{3}\right]$,

$q$ is specific discharge [L/T],

$\bar{\rho}$ is source/sink fluid density $\left[\mathrm{M} / \mathrm{L}^{3}\right]$,

$\bar{q}$ is a source/sink rate term $\left[\mathrm{T}^{-1}\right]$,

$S_{P}$ is specific storage in terms of pressure $\left[\mathrm{LT}^{2} / \mathrm{M}\right]$,

$P$ is pressure $\left[\mathrm{M} / \mathrm{LT}^{2}\right]$,

$t$ is time [T],

$n$ is porosity [dimensionless], and

$C$ is the concentration of the dissolved constituent that affects fluid density $\left[\mathrm{M} / \mathrm{L}^{3}\right]$.

Equation 2 is valid when the density variations are caused by solute concentration rather than temperature. For this study, temperature is assumed to be spatially uniform and temporally constant.

To solve the ground-water flow equation, the solute-transport equation also must be solved because concentration is a function of time and location. For dissolved constituents that are conservative, such as those found in seawater, the solute-transport equation is:

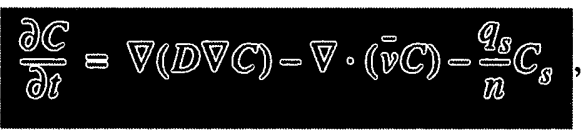

where:

$D$ is the dispersion coefficient $\left[\mathrm{L}^{2} / \mathrm{T}\right]$,

$\bar{v}$ is velocity $[\mathrm{L} / \mathrm{T}]$,

$q_{s}$ is the volumetric flux of a source or sink $\left[\mathrm{T}^{-1}\right]$, and

$C_{S}$ is the concentration of the source or sink $\left[\mathrm{M} / \mathrm{L}^{3}\right]$.
The ground-water flow and transport equations are coupled through the velocity term $\bar{v}$, which is the specific discharge divided by porosity, and $\frac{\partial C}{\partial t}$. Exact solutions to equations 2 and 3 , therefore, require that both mathematical expressions be simultaneously solved. In this study, however, the equations are not simultaneously solved, but rather, a one timestep lag is used.

In the form presented above, equation 2 uses pressure as an independent variable. Guo and Bennet (1998) use an alternative form of the ground-water flow equation written in terms of equivalent freshwater head. The following discussion presents the mathematical derivation of the ground-water flow equation in terms of freshwater head. This derivation is presented because the variable-density flow code, SEAWAT, uses freshwater head rather than pressure.

Darcy's law for ground water of variable density is written as:

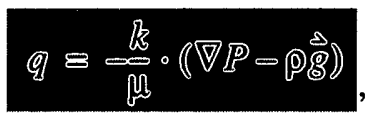

where $\overrightarrow{\boldsymbol{g}}$ is the gravity vector. For flow in the horizontal plane (denoted by $x$ ), equation 4 is simplified as:

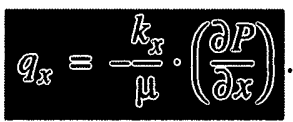

For flow in the vertical plane (denoted by z), Darcy's law is written as:

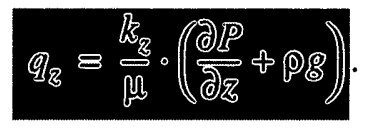

In equation 6 , the gravity vector $\overrightarrow{\boldsymbol{g}}$, which is directed downward, has been replaced by a scalar quantity, $-g$. For aquifers with constant fluid density, head is generally used as the independent variable because it is easily measured. Head is defined as the elevation to which ground water will rise in a cased well. Mathematically, head $(h)$ is expressed by the following equation:

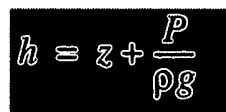


For variable-density systems, the flow of ground water cannot be described solely by head, and thus, equations are written in terms of pressure. Rather than use pressure as an independent variable, Lusczynski (1961) first suggested the use of equivalent freshwater head. Freshwater head is defined as the elevation to which freshwater will rise in a cased well. The following equation converts from head at a specific density $\rho$ to freshwater head $h_{f}$ :

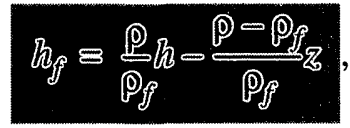

where $\rho_{f}$ is the density of freshwater. The freshwater head is also described by the following equation:

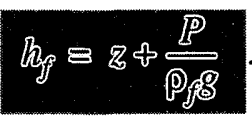

By solving for $P$ in equation 9, substituting for $P$ in equations 5 and 6, and simplifying, Darcy's law for horizontal and vertical flow is:

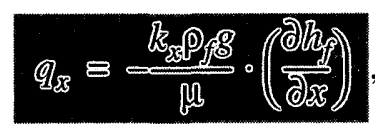

and

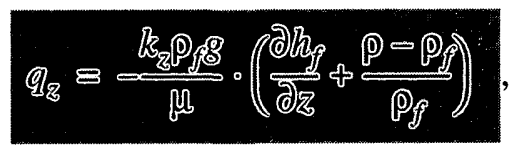

respectively.

The coefficients on the right-hand side of equations 10 and $11, \frac{k \rho_{f} g}{\mu}$, are collectively referred to as equivalent freshwater hydraulic conductivity $\left(K_{f}\right)$, which is the hydraulic conductivity of a porous media that is saturated with freshwater. The storage term in equation 2 can also be rewritten in terms of freshwater head using the relation, $S_{f}=g \rho_{f} S_{p}$. The equivalent freshwater storage term, $S_{f}$, is defined as the volumetric release of freshwater from storage per unit area per unit decline in freshwater head.

By substituting equivalent freshwater hydraulic conductivity and the equivalent freshwater storage term, the ground-water flow equation becomes:

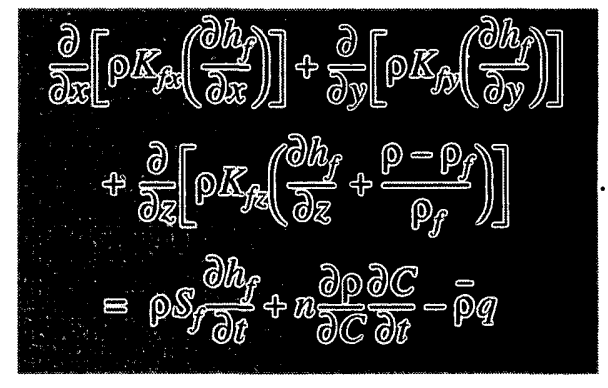

Included in this equation is the assumption that the dynamic viscosity of ground water with dissolved solids is equal to the dynamic viscosity of freshwater.

\section{SEAWAT Simulation Code}

The original SEAWAT code was written by Guo and Bennet (1998) to simulate ground-water flow and saltwater intrusion in coastal environments. SEAWAT uses a modified version of MODFLOW (McDonald and Harbaugh, 1988) to solve the variable-density, ground-water flow equation and MT3D (Zheng, 1990) to solve the solute-transport equation. To minimize complexity and run times, the SEAWAT code uses a one-step lag between solutions of flow and transport. This means that MT3D runs for a timestep, and then MODFLOW runs for the same timestep using the last concentrations from MT3D to calculate the density terms in the flow equation. For the next timestep, velocities from the current MODFLOW solution are used by MT3D to solve the transport equation. For most simulations, the one-step lag does not introduce significant error (C.I. Voss, U.S. Geological Survey, oral commun., 1999), and the error can be reduced or evaluated by decreasing the length of the timestep.

One major reason the SEAWAT code was selected for this study is that it uses MT3D to solve the transport equation. MT3D contains a variety of methods for solving the transport equation including the method of characteristics (MOC), modified method of characteristics (MMOC), hybrid method of characteristics (HMOC), and a standard finite-difference method. During the simulation of solute transport, numerical dispersion and other problems often are encountered. Because MT3D has a variety of solution techniques, including MOC, which is ideal for reducing numerical dispersion, an acceptable solution can usually be obtained.

Another advantage for using SEAWAT is that it uses two widely accepted modeling codes: MODFLOW and MT3D. This means that SEAWAT is 
modular and contains the "package" approach for including various boundary conditions and transport options. Additionally, SEAWAT reads and writes standard MODFLOW and MT3D data files, which are easily manipulated with the commercially available preand post-processors. These pre- and post-processors can substantially reduce the length of time required to create input data sets and evaluate model results.

The original SEAWAT code (Guo and Bennet, 1998) was modified for this study. Documentation for the new version of the code (Version 2) is currently in preparation. A general description of the improvements is presented in Langevin and Guo (1999). The most significant modification is the incorporation of an updated flow equation that conserves mass (as written in eq. 12) instead of volume. Additionally, the boundary fluxes were updated to use variable-density forms of Darcy's law. This modification allows boundary conditions to contain variable-density source waters. SEAWAT also has an option to use a modified algorithm for evapotranspiration, which allows evapotranspiration to be withdrawn from the highest active layer.

Because SEAWAT is a relatively new code, it was verified by running three test problems and comparing the simulated results with results from other codes and analytical solutions. The comparisons are presented in appendix IV.

\section{Cross-Sectional Ground-Water Flow Models}

Two cross-sectional models were developed at the local scale to simulate the discharge of ground water to Biscayne Bay. These models were developed in conjunction with the regional-scale model to achieve two objectives. First, the cross-sectional models were used to help facilitate development of the regional-scale model. The cross-sectional models simulate flow in only two dimensions, and therefore, run relatively fast compared to the three-dimensional, regional-scale model. For this reason, the crosssectional models are better suited for calibrating certain aquifer parameters and performing a comprehensive sensitivity analysis. The second objective for developing the cross-sectional models was to simulate the ground-water discharge patterns in detail with a fine level of spatial resolution. Because of limitations in computer processing, a regional-scale model cannot efficiently simulate local-scale ground-water discharge patterns in detail.

The two cross-sectional models were constructed along ground-water flow lines toward Biscayne Bay. The northern model simulates groundwater flow in the Coconut Grove area. The central model simulates flow for the Cutler Ridge area near the Deering Estate. A cross-sectional model was not designed for the Mowry Canal transect because the transect does not follow a ground-water flow line. The cross-sectional models were designed to simulate average ground-water flow conditions from March 1998 to February 1999. This period of time was selected because it corresponds with the period when field data were collected for this study. The hydrogeologic stresses included in the model are lateral flows from inland, net recharge, and ground-water discharge to Biscayne Bay.

\section{Model Design}

A common method for orienting two-dimensional, cross-sectional models is to align the horizontal axis with a linear or curving ground-water flow line. This method relies on the definition of a flow line, which does not allow ground water to flow across the line. Ground-water flow, therefore, can be simulated in two dimensions, one along the flow line and the other in the vertical direction. This is the general approach used for the Coconut Grove and Deering Estate crosssectional models. For both areas, a ground-water flow line was drawn through the monitoring wells using the 1993 water-table maps (figs. 4 and 5) and contours of the water table from a preliminary simulation of the regional-scale model. The inland extent for each model (fig. 16) is located west of the saltwater tongue and near a monitoring well or surface-water feature. The models extend offshore, past locations where measured ground-water salinities in monitoring wells were equal to the salinity of seawater. Based on field data and preliminary results from the regional-scale model, the general orientation and extent of the crosssectional models seem reasonable for simulating localscale ground-water discharge to Biscayne Bay.

One major difference between the two models is the simulated horizontal distance. From the coast, the Coconut Grove model extends 5,900 m inland, whereas the Deering Estate model extends $1,550 \mathrm{~m}$ inland. This is because the saltwater tongue is much farther inland near Coconut Grove than at the Deering Estate transect. The total lengths of the flow line 

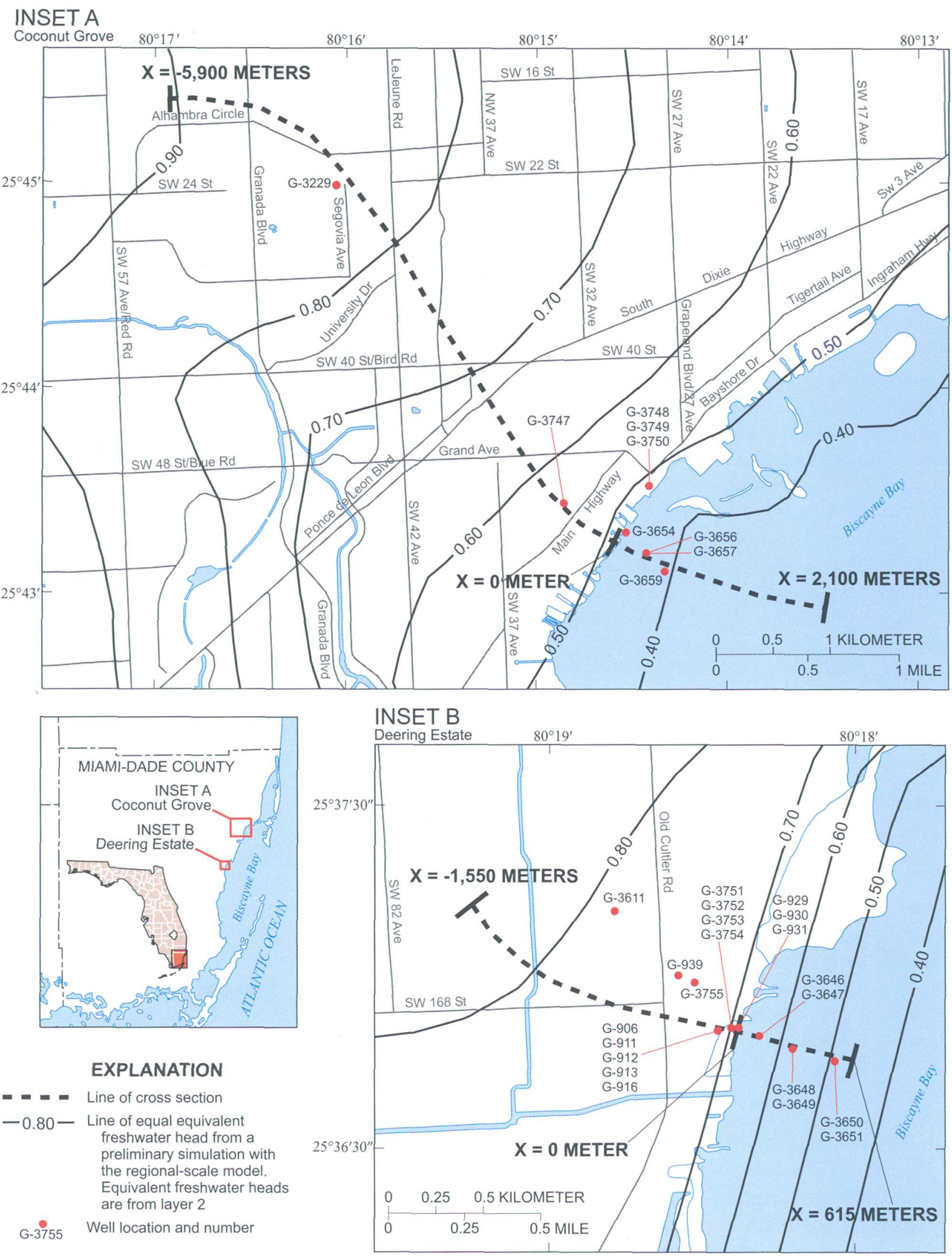

Figure 16. Location of the two-dimensional, cross-sectional models for (A) Coconut Grove (B) and Deering Estate. 
simulated by the Coconut Grove and Deering Estate models are 8,000 and 2,165 m, respectively. The vertical distances used for the two models are relatively similar, with the difference explained by the spatial variability in the base of the Biscayne aquifer. The base of the Coconut Grove model is $40 \mathrm{~m}$ below sea level, and the base of the Deering model is $33 \mathrm{~m}$ below sea level.

For each model, a finite-difference grid was developed to adequately discretize the model domain. One of the objectives for grid development was to sufficiently discretize the model domain while minimizing the total number of model cells. For Coconut Grove, this results in a regularly spaced grid with 40 cells in the horizontal direction and 20 cells in the vertical direction. Each rectangular cell in the Coconut Grove model is $200 \mathrm{~m}$ horizontal by $2 \mathrm{~m}$ vertical. For the Deering Estate model, an irregularly spaced grid was constructed with 149 cells in the horizontal direction and 33 cells in the vertical direction. For most of the model domain, the cells are $10 \mathrm{~m}$ horizontal by $1 \mathrm{~m}$ vertical. Near the western boundary, however, the horizontal lengths of the model cells increase to a maximum length of $100 \mathrm{~m}$ to allow for finer resolution at the coast while maintaining the same total number of cells. Finer horizontal and vertical resolution was used for the Deering Estate model because more groundwater wells were available for calibration than for the Coconut Grove model.

The boundary conditions used for the Coconut Grove model (fig. 17A) generally are the same as those used for the Deering Estate model (fig. 17B). Recharge is applied to the inland portion of the upper boundary in both models. Biscayne Bay is represented by a horizontal constant freshwater head boundary with a constant salt concentration equivalent to that of seawater, $35 \mathrm{~kg} / \mathrm{m}^{3}$ (kilograms per cubic meter). By specifying a constant freshwater head boundary in layer 1, the elevation for the bottom of Biscayne Bay corresponds to the center elevation of layer 1; thus, the simulated bay bottom is flat with an elevation of $-1.0 \mathrm{~m}$ for Coconut Grove and $-0.5 \mathrm{~m}$ for Deering Estate. The eastern vertical boundary also is represented by a constant freshwater head boundary with a constant salt concentration of $35 \mathrm{~kg} / \mathrm{m}^{3}$. The constant freshwater head values, which increase with depth, were calculated using equation 8 . The lower boundary of each model (a no-flow boundary) represents the base of the Biscayne aquifer. For the western boundary, a constant freshwater flux is evenly apportioned to each of the model cells. This freshwater flux represents the general flow of ground water toward the coast.

For both models, a stage value of $0.22 \mathrm{~m}$ was used to calculate the value for freshwater head assigned to each cell of the bay boundary. A stage value of $0.22 \mathrm{~m}$ represents an average value for sea level from 1989 to 1998 and was calculated from the downstream station at structure S-123. A net recharge value of $38 \mathrm{~cm} / \mathrm{yr}$ (centimeters per year), which includes evapotranspiration, was assigned to the overlying recharge boundaries in both models. While this value is a rough estimate, the sensitivity analysis (presented later in this section) suggests that the model is not very sensitive to recharge. The hydraulic gradient was used to estimate the constant flux assigned to the western boundary. Based on the 1993 water-table maps (figs. 4 and 5) and the results of the regionalscale simulation, the approximate hydraulic gradient for the Coconut Grove area is $4 \times 10^{-5} \mathrm{~m} / \mathrm{m}$ (meters per meter). The hydraulic gradient for the Deering Estate area cannot be estimated from the water-table maps (figs. 4 and 5) because there are not enough contours, but results from a preliminary simulation of the regional-scale model suggested that $5 \times 10^{-5}$ (meter of head per meter of lateral distance) may be reasonable. Attempts were made to maintain these hydraulic gradients at the western boundaries during the calibration of horizontal hydraulic conductivity. The actual flux value, therefore, is a result of calibration.

\section{Model Calibration and Simulation Results}

The Coconut Grove and Deering Estate crosssectional models were calibrated by adjusting the boundary stresses and aquifer parameters, within a range of reasonable values, until simulated conditions generally matched the conditions observed in the field. In both models aquifer parameters are represented by a homogenous distribution rather than a more complex heterogeneous distribution. Results obtained from this simplistic method for calibrating the cross-sectional models are thought to be useful for calibrating the regional-scale model.

The two models were calibrated to data collected from monitoring wells located on or near the model transects. The data values used in the calibration are presented in table 2 . For monitoring wells that are not located directly on a model transect, the horizontal distance was specified as the approximate distance of the monitoring well from the coastline. This 


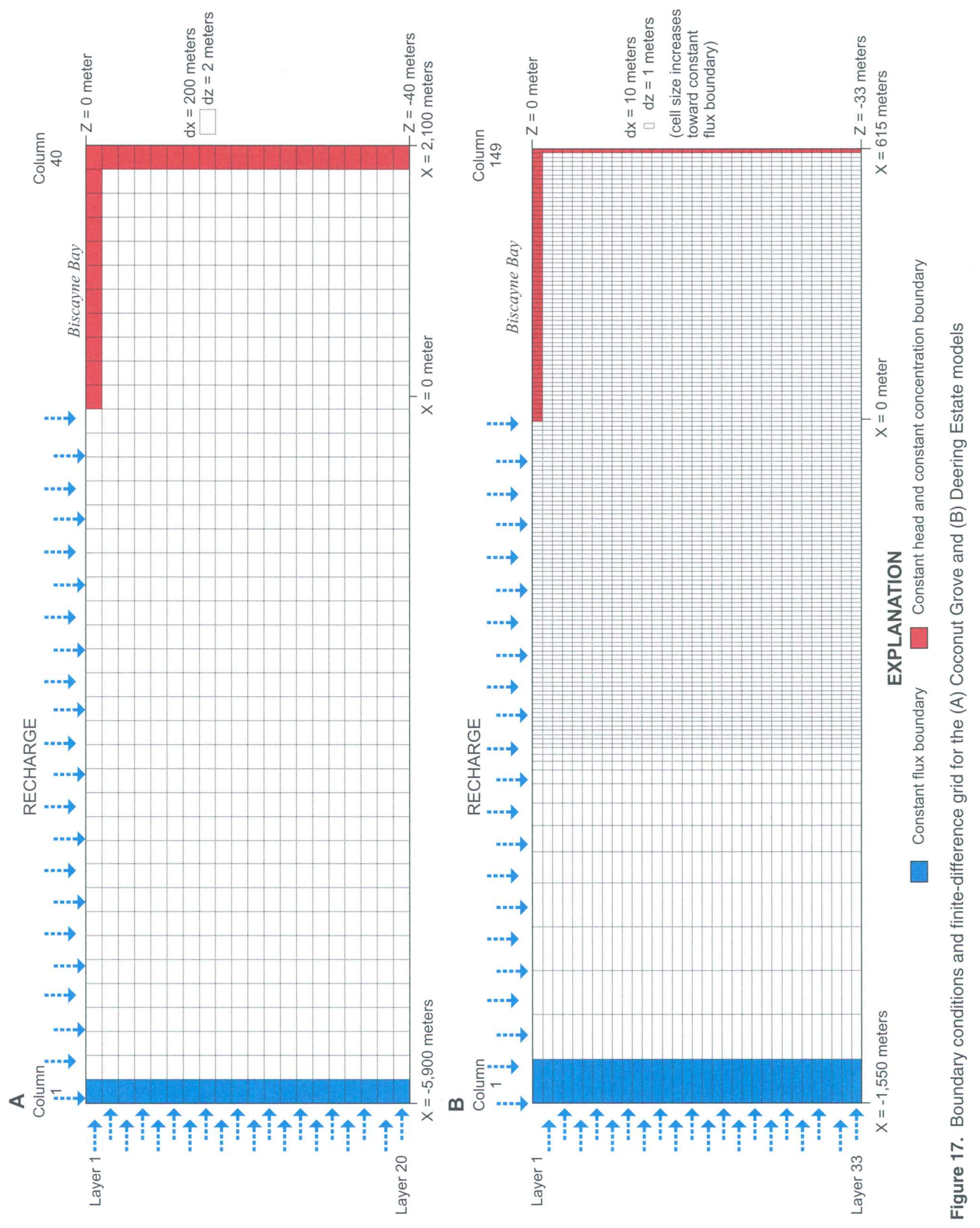


method for projecting the monitoring wells onto a model axis assumes that contours of head and salinity are parallel to the coastline and perpendicular to the model cross section. This assumption may limit confidence in the calibration if actual contours of salinity and head are not parallel to the coast. The elevation of the screen center was used to locate the measurements of head and salinity within the vertical section of the model. Most of the well screens are $1.52 \mathrm{~m}$ in length, which means that the heads and salinity values measured at the wells were vertically averaged over this distance. Although the screen length is longer than the cell height for the Deering Estate model, the vertically averaged head and salinity values should not cause significant errors in the model calibration.

\begin{tabular}{|c|c|c|}
\hline \multicolumn{3}{|c|}{$\begin{array}{l}{\left[K_{H}, \text { horizontal hydraulic conductivity, } K_{\downarrow} \text { vertical hydraulic conduc- }\right.} \\
\text { tivity; } \alpha_{L}, \text { longitudinal dispersivity; } \alpha_{T} \text {, transverse dispersivity; } \\
n \text {, porosity; } Q / m \text {, lateral influx; } R \text {, recharge] }\end{array}$} \\
\hline \multirow{2}{*}{$\begin{array}{l}\text { Parameter/stress } \\
\text { (units) }\end{array}$} & \multicolumn{2}{|c|}{ Cross-sectional model } \\
\hline & $\begin{array}{l}\text { Coconut } \\
\text { Grove }\end{array}$ & $\begin{array}{l}\text { Deering } \\
\text { Estate }\end{array}$ \\
\hline$K_{H}$, in meters per day & 9,000 & 1,000 \\
\hline$K_{V}$ in meters per day & 9 & 100 \\
\hline$\alpha_{L}$, in meters & 1 & 10 \\
\hline$\alpha_{T}$, in meters & .1 & 1 \\
\hline$n$ (dimensionless) & .2 & .2 \\
\hline $\begin{array}{l}Q / m \text {, in cubic meters per day } \\
\text { (per meter of shoreline) }\end{array}$ & 15 & 5 \\
\hline$R$, in centimeters per year & 38 & 38 \\
\hline
\end{tabular}

The aquifer parameters and boundary stresses used in the final versions of the calibrated models for Coconut Grove and Deering Estate are presented in table 4. The parameters and stresses used in the Coconut Grove model are comparable to within one order of magnitude to the parameters and stresses used in the Deering Estate model. Results from the calibrated models generally match with field data (fig. 18). The simulated transition zone appears to be of reasonable width, the toe is simulated near the position observed in the field, and the simulated water table is similar in elevation to measured ground-water levels. It is clear, however, that the models do not accurately simulate ground-water salinities directly beneath Biscayne Bay near the shoreline; in both models, simulated values of ground-water salinity are too high. A combination of aquifer parameters that would reproduce these low salinity values could not be found with a spatially homogeneous distribution. This suggests that the low salinities beneath the bay may be affected by a complex distribution of hydraulic conductivity. For example, a highly transmissive aquifer layer that is bounded on the top and bottom by lower permeability units could possibly transmit lower salinity ground water offshore beneath the bay. The constant-concentration boundary condition used for Biscayne Bay also may be causing increased salinities beneath the bay. Recent research has shown that specifying the concentration for inflow from a constant-head boundary may be more appropriate than a constant-concentration boundary for certain applications. Future simulations may also benefit from better estimates of salinity for Biscayne Bay; for the cross-sectional models, the salinity value used to represent the bay $\left(35 \mathrm{~kg} / \mathrm{m}^{3}\right)$ is probably too high.

Because the models did not accurately represent the relatively low salinities beneath Biscayne Bay, the simulated ground-water discharge patterns may be inaccurate. Despite this probable error, a plot of simulated discharge relative to distance from shore for the Deering Estate model is shown in figure 19. Simulated values of ground-water discharge were calculated by tabulating the flow from the active model domain into the constant-head cells that represent Biscayne Bay. Model results suggest that most of the ground-water discharge to Biscayne Bay is very near the coast. The field data suggest, however, that ground-water discharge to Biscayne Bay may occur as far offshore as $500 \mathrm{~m}$ (fig. 10). The negative groundwater discharge values indicate that seawater is being circulated back into the aquifer. A similar plot of discharge for the Coconut Grove model is not included because all ground-water discharge is to the first constant-head cell representing Biscayne Bay.

Water budgets were prepared from the results of the Coconut Grove and Deering Estate models to provide general insight into the coastal ground-water flow systems. As expected, simulated water budgets indicate that volumetric inflows are roughly equivalent to outflows (fig. 20). Differences between volumetric inflows and outflows are explained by the 2.5 percent density difference between freshwater and seawater. For both models, recirculated seawater (inflow from eastern constant-head boundaries) comprises a large percentage of the simulated ground-water discharge to Biscayne Bay. This supports the notion by Kohout 

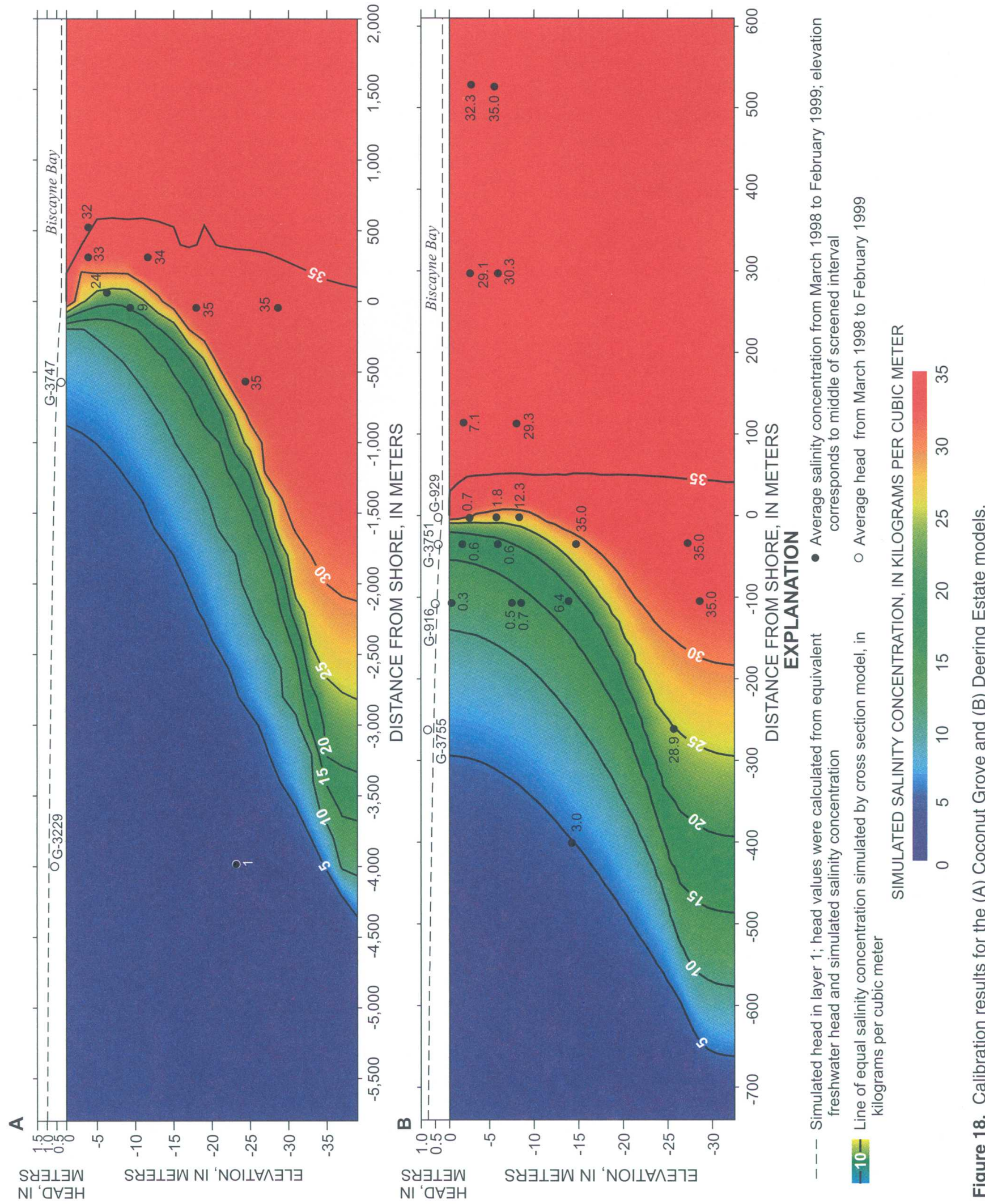


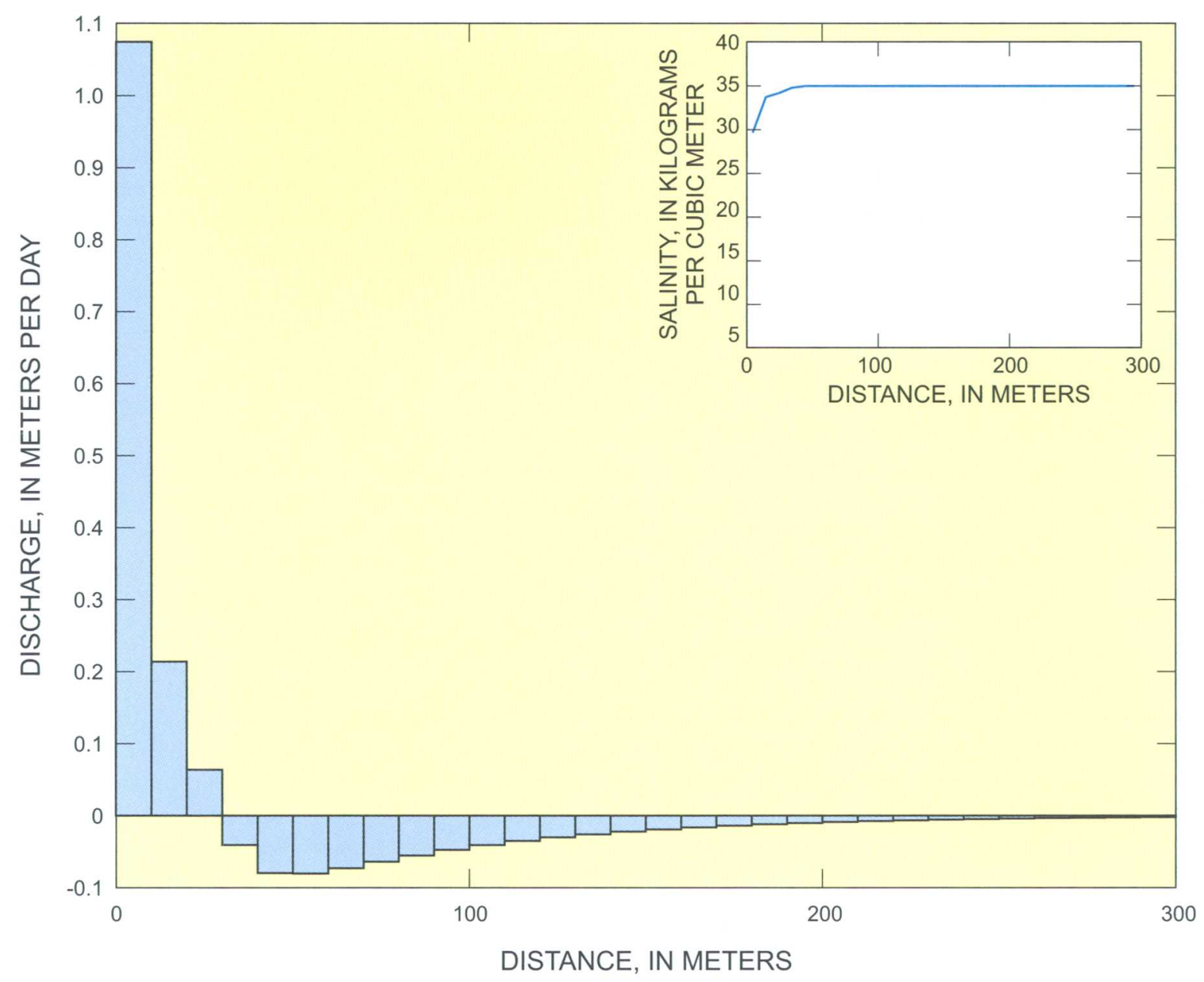

Figure 19. Simulated ground-water discharge to Biscayne Bay for the Deering Estate model. Discharge includes freshwater and brackish-water components.

(1960a) that only a fraction of the total ground-water discharge to Biscayne Bay is fresh ground water from farther inland. Based on the water budgets, the models suggest that about 35 to 60 percent of the submarine discharge is recirculated seawater, but these estimates may be affected by the model's inability to simulate concentrations beneath the bay.

\section{Sensitivity Analysis}

A sensitivity analysis was performed to evaluate the effects of the different aquifer parameters and boundary conditions on the simulated ground-water heads and salinities. For each sensitivity run, only the examined parameter or boundary condition is adjusted from the value used in the calibrated model, referred to as the base case. For each model, parameters were qualitatively assigned either a small, moderate, or large effect based on the simulated salinities and heads.

The value for horizontal hydraulic conductivity, $K_{h}$, has a moderate effect on the simulated heads and salinities. When the value for $K_{h}$ decreases, simulated heads increase and the salinity contours move seaward (pls. 1 and 2). The opposite occurs when $K_{h}$ increases. Interestingly, the effects of $K_{h}$ are most pronounced with the 0.05 and 0.5 relative salinity contours. $K_{h}$ does not significantly affect the 0.95 contours, which tend to be "locked" at the coast. Thus, for the same set of aquifer parameters and boundary conditions, simulations with lower values of $K_{h}$ will result in a narrower transition zone relative to simulations with larger values for $K_{h}$. This observation, which applies to both the Coconut Grove and Deering Estate models, is probably due to higher dispersion for simulations with high values of $K_{h}$. 


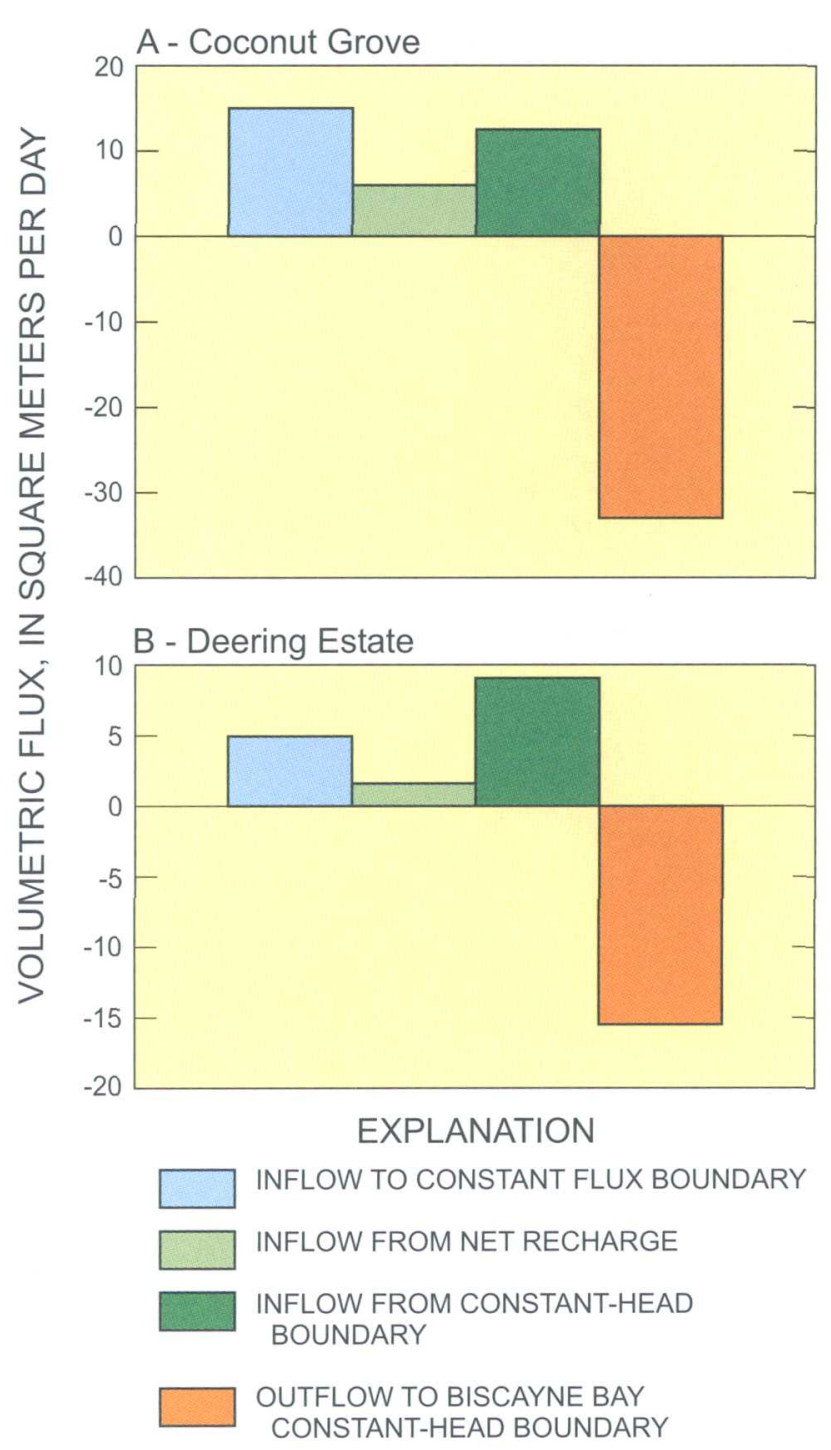

Figure 20. Simulated water budget for the (A) Coconut Grove and (B) Deering Estate models.

The effect of vertical hydraulic conductivity, $K_{v}$, ranges from small to large depending on the model and whether the value is increased or decreased. It is evident from plates 1 and 2 that $K_{v}$ affects the simulated distribution of salinity. Decreases in $K_{v}$ cause the 0.95 salinity contours to move seaward and extend beneath Biscayne Bay. By using $K_{v}$ values that are lower than the ones used in the two base case models, simulated values of ground-water salinity could decrease beneath the bay. While this would improve the model results beneath the bay, a decrease in $K_{v}$ would worsen the match between observed and simulated salinities at the base of the aquifer. This further supports the notion that the distribution for hydraulic conductivity is not homogeneous. Increases in $K_{v}$ do not significantly affect salinity contours. There seems to be a threshold beyond which increases in $K_{v}$ no longer affect model results.

Surprisingly, longitudinal dispersivity, $\alpha_{L}$, does not significantly affect simulated salinities and heads; however, transverse dispersivity, $\alpha_{T}$, does significantly affect the model results. Although $\alpha_{L}$ does not seem to affect model results, $\alpha_{L}$ values in the calibrated models were held 10 times larger than $\alpha_{T}$, a ratio commonly reported in the literature. When low $\alpha_{T}$ values are used, salinity contours become elongated and extend farther inland. High $\alpha_{T}$ values tend to produce salinity contours that are more vertical. Combining lower $\alpha_{T}$ and $K_{v}$ values may be one way to better match the available field data. Such a simulation might produce higher salinities at the base of the aquifer and lower salinities beneath the bay.

Changing the flux at the western boundary, $Q / m$, has a moderate effect on model results. The effect is nearly opposite to changing $K_{h}$. When $Q / m$ is decreased, salinity contours move inland and heads decrease. When $Q / m$ is increased, salinity contours move seaward and heads increase. The fact that $Q / m$ has the opposite effect of $K_{h}$ means that many different combinations of $K_{h}$ and $Q / m$ could produce the same head and salinity distribution, but discharge patterns may be different.

The cross-sectional models are not very sensitive to changes in recharge. When recharge rates are increased, salinity contours move slightly seaward and the heads slightly increase. When recharge rates are decreased, salinity contours move slightly landward and the heads decrease.

\section{Regional-Scale Ground-Water Flow Model}

The regional-scale model simulates the flow of ground water from January 1989 to August 1998 for most of Miami-Dade County and parts of Broward and Monroe Counties. Results from preliminary model runs suggested that 5 to 10 years would be sufficient to eliminate the effects of initial conditions. Model results early in the simulation period should be interpreted with additional caution because they may contain residual errors from inadequate initial conditions. The hydrogeologic stresses included in the model are flows from lateral boundaries, areal recharge, evapotranspiration, ground-water flow to 
and from canals, recharge from surface water in the Everglades, ground-water withdrawals from municipal well fields, and ground-water discharge to Biscayne Bay (fig. 15).

Estimates of ground-water discharge to Biscayne Bay were obtained through the development and calibration of the regional-scale, variable-density, ground-water flow model. A major assumption with this approach for estimating ground-water discharge to Biscayne Bay is that realistic discharge quantities will be obtained by calibrating the numerical model to observed conditions. This means that the accuracy of the discharge estimates is dependent on calibration, which is inherently limited. A sensitivity analysis with the calibrated model was used to bracket a reasonable range of probable discharge estimates.

\section{Spatial and Temporal Discretization}

To simulate ground-water flow to Biscayne Bay, a regularly spaced, finite-difference model grid was constructed and rotated so that the $y$-axis would roughly parallel the coast (fig. 21). Each cell is 1,000 by $1,000 \mathrm{~m}$ square in the horizontal plane. The grid consists of 89 rows and 71 columns, and the rotation angle from true north is clockwise 14 degrees. The purpose for rotating the grid is to align model rows with the principal direction of ground-water flow, which primarily is toward Biscayne Bay. When ground-water flow is parallel to one of the primary model axes, problems with numerical dispersion that result from solving the transport equation are minimized. Another reason for rotating the model grid is that future modifications to the model may require a higher level of discretization at the coast. A rotated model grid will allow the resolution along a flow line to be increased by dividing columns near the coast. This modification would be relatively simple to implement but would increase computer run times.

Accurate simulation of variable-density flow systems requires a higher level of vertical discretization compared to that required for simulating constantdensity flow systems. Accordingly, the model grid consists of 11 layers, more layers than would be required for a typical ground-water flow model that does not simulate variable-density flow. During the initial stages of calibration, the upper layer was used to approximate overland surface-water flow in Everglades National Park and Water Conservation Areas $3 \mathrm{~A}$ and 3B. This upper layer caused numerical insta- bilities and increased simulation times. As a result, the entire upper layer (layer 1) was inactivated early in the development of the model. Rather than remove this upper layer, it remains in the model in case future simulations require the representation of overland flow.

Layers 2 through 11 represent the Biscayne aquifer. The top of layer 2 is spatially variable and corresponds with land-surface elevation (fig. 22), based on a topographic contour map provided by Everglades National Park. For model cells that lie within Biscayne Bay, the top of layer 2 has a value of $0.0 \mathrm{~m}$. The bottom of layer 2 is set at an elevation of $5.0 \mathrm{~m}$ below sea level. To minimize the effects of numerical problems that can occur in solute-transport models, the grid was designed so that most of the cells would have a uniform volume $(1,000 \times 1,000 \times 5 \mathrm{~m})$. Although the volume for each model cell in layer 2 may be slightly variable because of the variation in land-surface elevation, model cells in layers 3 to 11 have a uniform thickness of $5 \mathrm{~m}$ and thus a uniform cell volume. The bottom elevation for layer 11 is $50 \mathrm{~m}$ below sea level. The base of the Biscayne aquifer, as defined by Fish and Stewart (1991), generally slopes from west to east. This variability in aquifer thickness was included in the model by inactivating model cells with cell centers below the base of the Biscayne aquifer.

The simulation is divided into 116 monthly stress periods. For each stress period, the average hydrologic conditions for that month are assumed to remain constant. This means that the model does not simulate hourly or daily hydrologic variations, but rather seasonal and yearly variations. Further temporal discretization is introduced in the form of transport steps. Each stress period is divided into one or more transport steps, the lengths of which are determined by SEAWAT to meet specified criteria associated with solving the solute-transport equation. For the regionalscale model, about 20 transport steps were required for each stress period.

\section{Assignment of Aquifer Parameters}

The approach for assigning aquifer parameters that pertain to ground-water flow and solute transport was to use the simplest distribution that would result in adequate representation of the flow system. For the model parameter that has the largest effect on groundwater flow, horizontal hydraulic conductivity, most of the model was assigned a single value of $9,000 \mathrm{~m} / \mathrm{d}$, though two other zones were assigned lower values (pl. 3). The value of $9,000 \mathrm{~m} / \mathrm{d}$ is similar to the value 


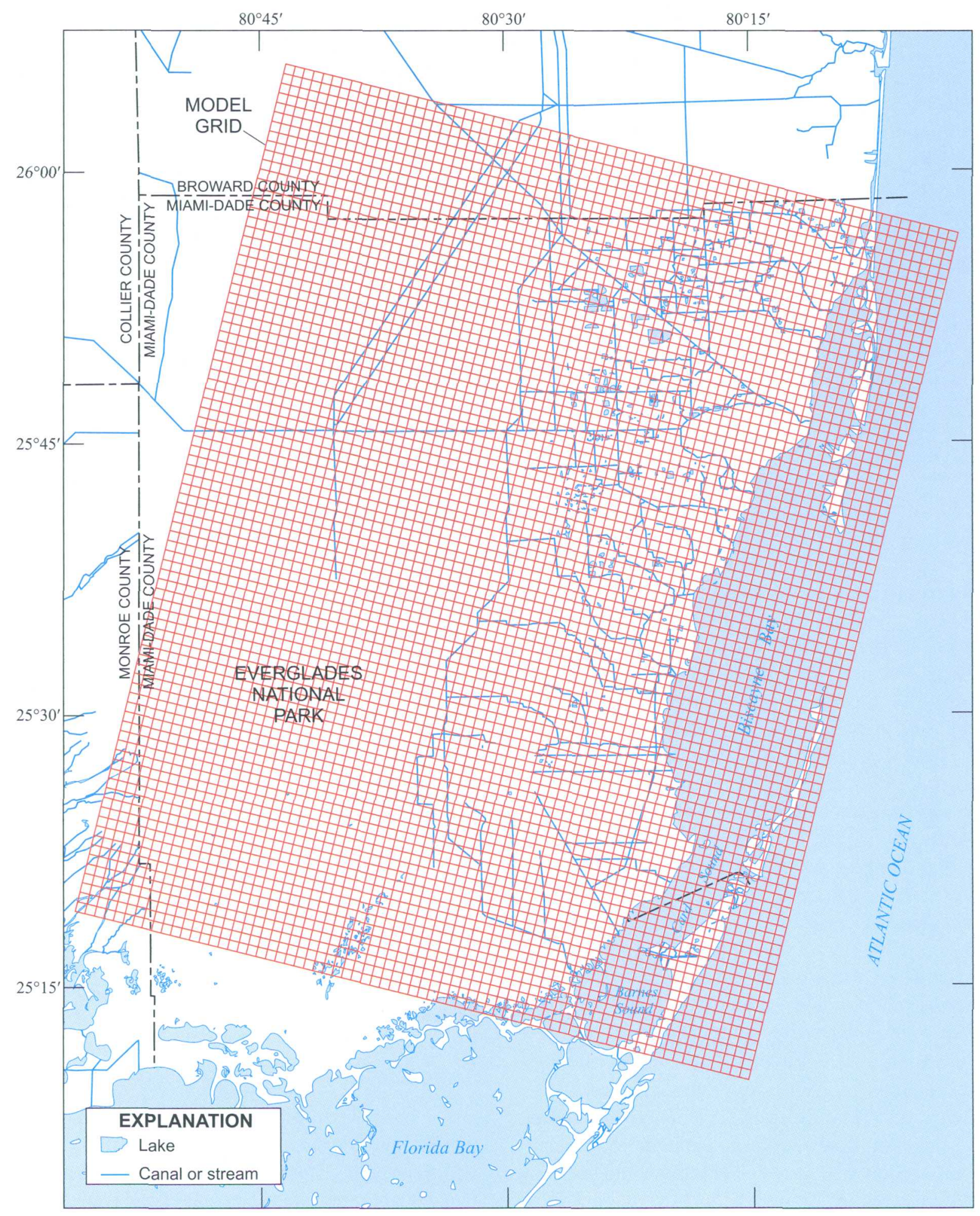

Figure 21. Finite-difference grid for the regional-scale ground-water flow model in southern Florida. 


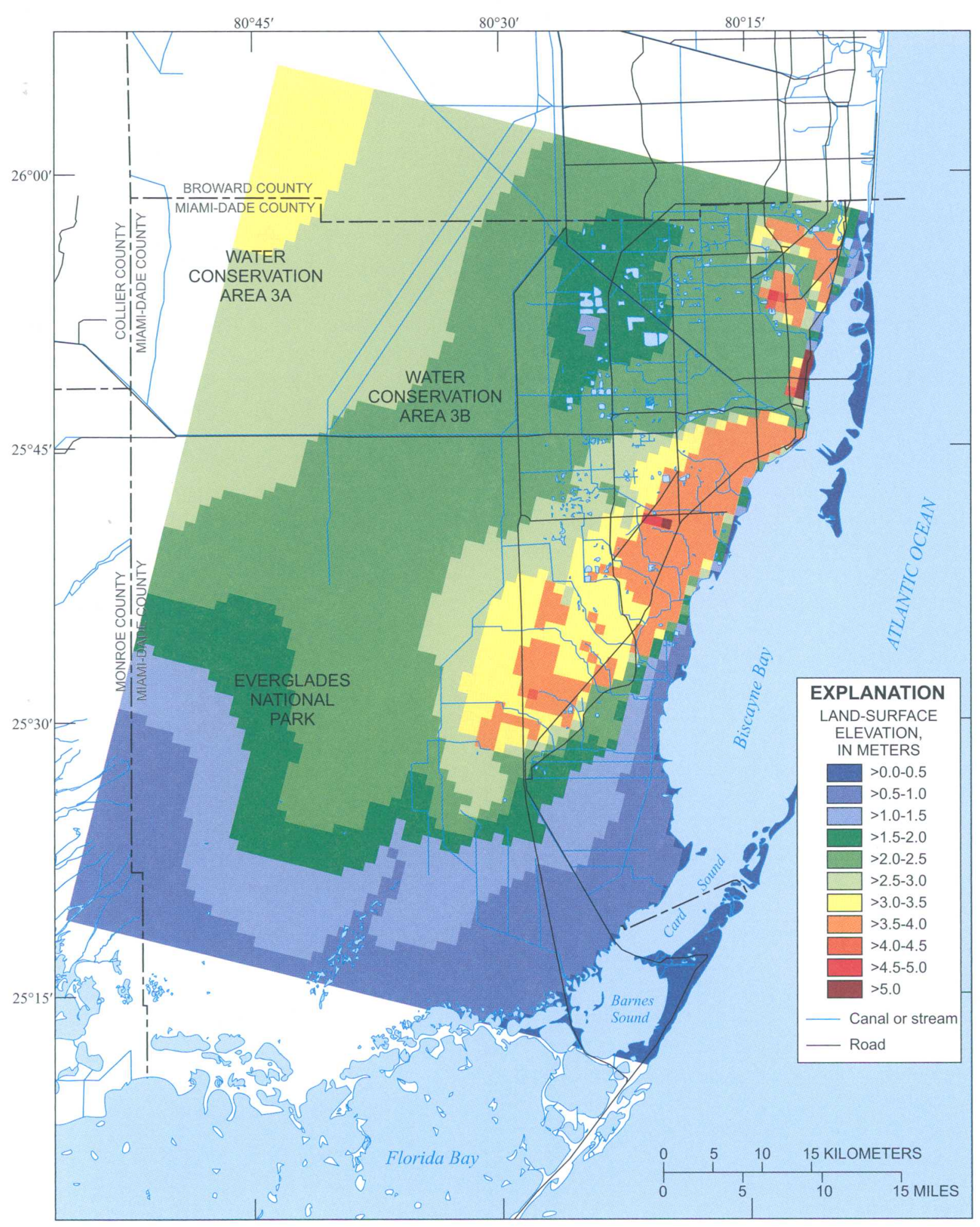

Figure 22. Land-surface elevation of southern Florida used in the regional-scale ground-water flow model. 
of hydraulic conductivity used by Merritt (1996a) for most of the model domain in southern Dade County to describe the Miami Limestone, Fort Thompson Formation, and permeable zones of the Tamiami Formation. For the northeastern and southern parts of the model, a relatively low value for horizontal hydraulic conductivity $(3 \mathrm{~m} / \mathrm{d})$ was assigned to the upper layer to represent the peat and marl units that comprise the upper part of the Biscayne aquifer. Another zone, located near the central part of the model along the coast, was assigned a value of $1,500 \mathrm{~m} / \mathrm{d}$. Merritt (1996a) includes this zone to match the flow patterns and head values observed in this area. A constant anisotropy ratio of 100:1 was arbitrarily selected to represent the ratio of horizontal hydraulic conductivity to vertical hydraulic conductivity. Results from sensitivity analyses indicate that the anisotropy ratio does not significantly affect model results.

SEAWAT requires the input of primary (SF1) and secondary (SF2) storage values. The primary value is used in the flow equation when the head in a cell is above the top elevation of that cell. The secondary storage value is used for the water-table case when the water table lies within the model cell. For the uppermost active layer (layer 2), SF2 is equal to 0.2, the value of specific yield estimated by Merritt (1996a). SF1 is set to 1.0 for layer 2, a value that is appropriate when the water table rises above land surface. For layers 3 through $11, \mathrm{SF} 1$ is $5.9 \times 10^{-5}$ and $\mathrm{SF} 2$ is 0.2 . The storage value of $5.9 \times 10^{-5}$ was calculated using an average thickness of $30 \mathrm{~m}$ for the Biscayne aquifer and a value of $2 \times 10^{-10} \mathrm{~m}^{2}$ (square meters) per newton for aquifer compressibility of fractured rock (Domenico and Schwartz, 1990, p. 111).

Aquifer parameters required for solute transport include porosity and dispersivity. A constant porosity value of 0.2 was assigned to each layer. This value was selected because it is thought that the specific yield, which was determined by Merritt (1996a), is indicative of the effective porosity. The longitudinal and transverse dispersivity values used for the model are 5 and $0.5 \mathrm{~m}$, respectively. These dispersivity values were determined from the calibration of the cross-sectional models.

\section{Boundary Conditions}

For most simulations of ground-water flow, boundaries of the model are extended to locations in the aquifer where hydrogeologic boundaries reside. Ideally, these hydrogeologic boundaries are persistent flow lines, impermeable hydraulic barriers, or areas that can be represented with a constant flux or head. For this study, adequate hydrogeologic boundaries do not exist for the inland portion of the model domain. For this reason, the northern, western, and southern boundaries were extended outside of the area of interest and represented with head-dependent boundaries (pl. 3). The eastern boundary, numerically represented as a constant-head and constant-concentration boundary, corresponds to Biscayne Bay.

\section{Biscayne Bay}

The model cells in layer 2 representing Biscayne Bay (pl. 3) were simulated with the timevarying Constant-Head (CHD) package in SEAWAT and a constant salt concentration of $35 \mathrm{~kg} / \mathrm{m}^{3}$. By specifying a constant freshwater head boundary in layer 2, the elevation for the bottom of Biscayne Bay corresponds to the center elevation of layer 2; thus, the simulated bay bottom is flat with an elevation of $-2.5 \mathrm{~m}$. Average monthly values for downstream stage at structure S-123 (fig. 14) were used to set the water level in the constant-head cells. The downstream stage measurement at structure S-123 was used because this structure is located at the coast (fig. 4) and lies near the center of the model. As previously shown, the downstream stage value at structure S-123 is a reasonable approximation for sea-level elevation (fig. 14). From September 1992 to January 1993, the downstream stage at structure S-27 (fig. 4) was used to replace missing data at structure S-123. The average value for monthly stage was converted to freshwater head using the specified salt concentration of $35 \mathrm{~kg} / \mathrm{m}^{3}$ and an elevation of $2.5 \mathrm{~m}$ below sea level, which is the center elevation of the model cell. Monthly averages for the downstream stage at structure S-123 ranged from less than $0.05 \mathrm{~m}$ to greater than $0.45 \mathrm{~m}$ from 1989 to 1998 . These relatively large fluctuations in average monthly sea level are included in the representation of Biscayne Bay to better approximate ground-water flow near the coast.

\section{Inland Model Domain Boundaries}

To represent the lateral flow of ground water to or from the inland perimeter of the model, headdependent boundaries were assigned to each active cell (west of the Biscayne Bay shoreline) along the northern, western, and southern perimeters of the model (pl. 3). The General-Head Boundary (GHB) package in SEAWAT is used to represent head-dependent boundaries. The reservoir heads for the boundary 
cells were interpolated from a triangular irregular network (TIN) data model used to represent the watertable surface. A water-table TIN was created for each month of the simulation period (1989-98) using average monthly water levels from available surface-water and ground-water monitoring stations (app. III). Boundaries on the upper model surface in wetland regions will be discussed later.

Salt concentrations for boundary reservoirs were set equal to the initial concentration of the model cell (discussed in a later section). The concentration of the boundary reservoir remains constant throughout the simulation period. The concentration is zero for most GHB reservoirs, but for boundary cells near the coast, concentrations may be greater than zero. For boundary cells with concentrations greater than zero, reservoir heads were recalculated as equivalent freshwater heads using equation 8 . The calculation and assignment of equivalent freshwater heads (according to eq. 8) result in hydrostatic conditions for those boundaries. The assignment of hydrostatic conditions to the northern and southern boundaries is probably inappropriate near the coast because coastal groundwater flow patterns suggest that there can be a large vertical flow component. However, there is not sufficient quantitative data to set these coastal boundaries with a more appropriate condition. Simulated groundwater flow patterns near these boundaries, therefore, should be interpreted with caution.

\section{Lower Model Boundary}

The lower model boundary represents the base of the Biscayne aquifer. This boundary is represented in the model as an impermeable barrier, an approach typically used in Miami-Dade County (Merritt, 1996a; Swain and others, 1996). Although there may be upward vertical ground-water flow from deeper aquifers into the Biscayne aquifer, there is no evidence to suggest that this is necessary to include in the model.

\section{Internal Hydrologic Stresses}

Hydrologic stresses that are internal to the model domain are represented with internal boundary conditions. Internal hydrologic stresses include: canals, surface water in the Everglades, recharge, evapotranspiration, and ground-water withdrawals from municipal well fields.

\section{Canals}

The dynamic exchange of water between the Biscayne aquifer and major canals is simulated with the River (RIV) package in SEAWAT. The RIV package assigns a head-dependent flux to each model cell that is intersected by a major canal. The flux value is a function of the difference between canal stage and aquifer head and the level to which the canal is hydraulically connected to the aquifer. In the model, canal stages vary spatially and temporally, depending on the stage values that were observed in the field. Simulated flows to and from the canal cells are compared with the measured or computed flows in the canals to ensure that the model is accurately representing the system. This process is described later.

Although surface-water flow in the canals is not explicitly simulated, it is thought that this approach is reasonable for representing the interaction between canals and the Biscayne aquifer.

The canals included in the model primarily consist of major water-management canals (pl. 3). Minor canals, sometimes referred to as secondary or tertiary canals, generally were not included in the model. To facilitate model development, the major canal network was divided into individual canal segments based on hydrologic characteristics, network geometry, structure locations, and the hydrologic basin delineations by Cooper and Lane (1987). Each canal segment was assigned an identifying number, a canal bottom elevation, a canal width, a representative value for hydraulic conductivity between the aquifer and the canal, a representative value for flow length, and the upstream and downstream monitoring stations used to assign canal stages. Values for hydraulic conductivity and flow length were formulated using the conceptual model described by Swain and others (1996, p. 66). These values were modified during calibration so that simulated values of canal baseflow and aquifer heads would match those observed in the field.

Of the stress and boundary packages used in the regional-scale model, the RIV package was the most complex to develop. The RIV input file read by SEAWAT was created with the RIVGRID program (Leake and Claar, 1999). RIVGRID geometrically intersects a river (or canal) network with a model grid and calculates the hydraulic conductance for those model cells that contain a river. RIVGRID also calculates a stage for each RIV cell by linearly interpolating a value along the river segment. 
For tidal canal segments to the east of coastal control structures, the stages calculated by RIVGRID are corrected to equivalent freshwater heads. In the freshwater head calculation, it is assumed that the surface water in the tidal canal is pure seawater with a salt concentration of $35 \mathrm{~kg} / \mathrm{m}^{3}$. As required by SEAWAT, the elevation of the river bottom is used in equation 8 as the elevation term for the freshwater head calculation. A concentration of $35 \mathrm{~kg} / \mathrm{m}^{3}$ also is used to represent the salt concentration of the water that enters the aquifer from the tidal canals.

\section{Ponded Surface Water}

To represent the hydrologic effects of surface water in the Everglades and coastal lowlands, a GHB was included in model cells of layer 2 that had standing water above land surface. To determine whether or not there was standing water in a model cell, a TIN of the water table was created for each month using average monthly stage data from canals and average watertable elevations from monitoring wells. A water-level elevation was then interpolated from the TIN for each model cell. A GHB that represents surface water is active in the model when the water level interpolated from the TIN is higher than land surface and a RIV boundary does not exist in the same model cell. Plate 3 shows the model cells in layer 2 that have an active GHB for at least one stress period of the simulation. The conductance value for each GHB, determined through calibration, is $1 \times 10^{5} \mathrm{~m}^{2} / \mathrm{d}$. The salt concentration of the GHB fluid is specified as $0 \mathrm{~kg} / \mathrm{m}^{3}$.

\section{Recharge and Runoff}

The Recharge (RCH) package in SEAWAT is used to apply areal recharge to the model, with a specified salt concentration of $0 \mathrm{~kg} / \mathrm{m}^{3}$. The general procedure for estimating recharge values was to subtract from rainfall a quantity thought to be representative of runoff. The remaining quantity is applied to the model as recharge.

For each month of the simulation period, Thiessen polygons were constructed using the rainfall monitoring stations that had continuous data for that month. Because few rainfall stations had continuous data for the entire simulation period, the geometry and distribution of Thiessen polygons varies by month. A monthly rainfall total was then estimated for each model cell by intersecting the model grid with the Thiessen polygons and weighting the rainfall totals by the areas of the Thiessen polygons within the model cell. To calculate a recharge value for each cell and for each month, the rainfall totals were multiplied by runoff coefficients. The calculation of runoff coefficients was based on the assumption that runoff quantities are dependent on land use, an approach used by Restrepo and others (1992) to construct a ground-water flow model for Broward County. For the present study, runoff coefficients were estimated for each land-use category through model calibration and results provided by Restrepo and others (1992). Table 5 contains the calibrated runoff coefficients that were assigned to each land-use category. These runoff coefficients may include the effects of other processes, such as pumpage from the Biscayne aquifer for agricultural irrigation, and may not be appropriate for other areas or spatial scales. An average runoff coefficient was calculated for each model cell by intersecting the model grid with the 1995 land-use coverage (fig. 23) and calculating the runoff coefficient based on a weightedarea average.

Table 5. Runoff coefficients and evapotranspiration extinction depths for different land-use categories

$\begin{array}{lcc}\begin{array}{l}\text { [Values were determined from Restrepo and others (1992) } \\ \text { and from calibration of the regional-scale model] }\end{array} \\ \begin{array}{l}\text { Land-use } \\ \text { category }\end{array} & \begin{array}{c}\text { Runoff } \\ \text { coefficient }\end{array} & \begin{array}{c}\text { Extinction depth } \\ \text { (meters) }\end{array} \\ \text { Urban } & 0.5 & 0.30 \\ \text { Agriculture } & .5 & .43 \\ \text { Rangeland } & .2 & .61 \\ \text { Upland forests } & .2 & .70 \\ \text { Water } & .0 & .183 \\ \text { Wetlands } & .0 & .69 \\ \text { Barren land } & .0 & .15 \\ \text { Transportation } & .5 & .30\end{array}$

\section{Evapotranspiration}

The Evapotranspiration (EVT) package in SEAWAT, which withdraws ground water as a function of depth to the water table, is used to simulate evapotranspiration from the water table. The EVT package works by "pumping" ground water from the uppermost active model cell based on three, user-specified parameters (described in McDonald and Harbaugh, 1988): maximum evapotranspiration rate (QMAX), evapotranspiration surface (SURF), 


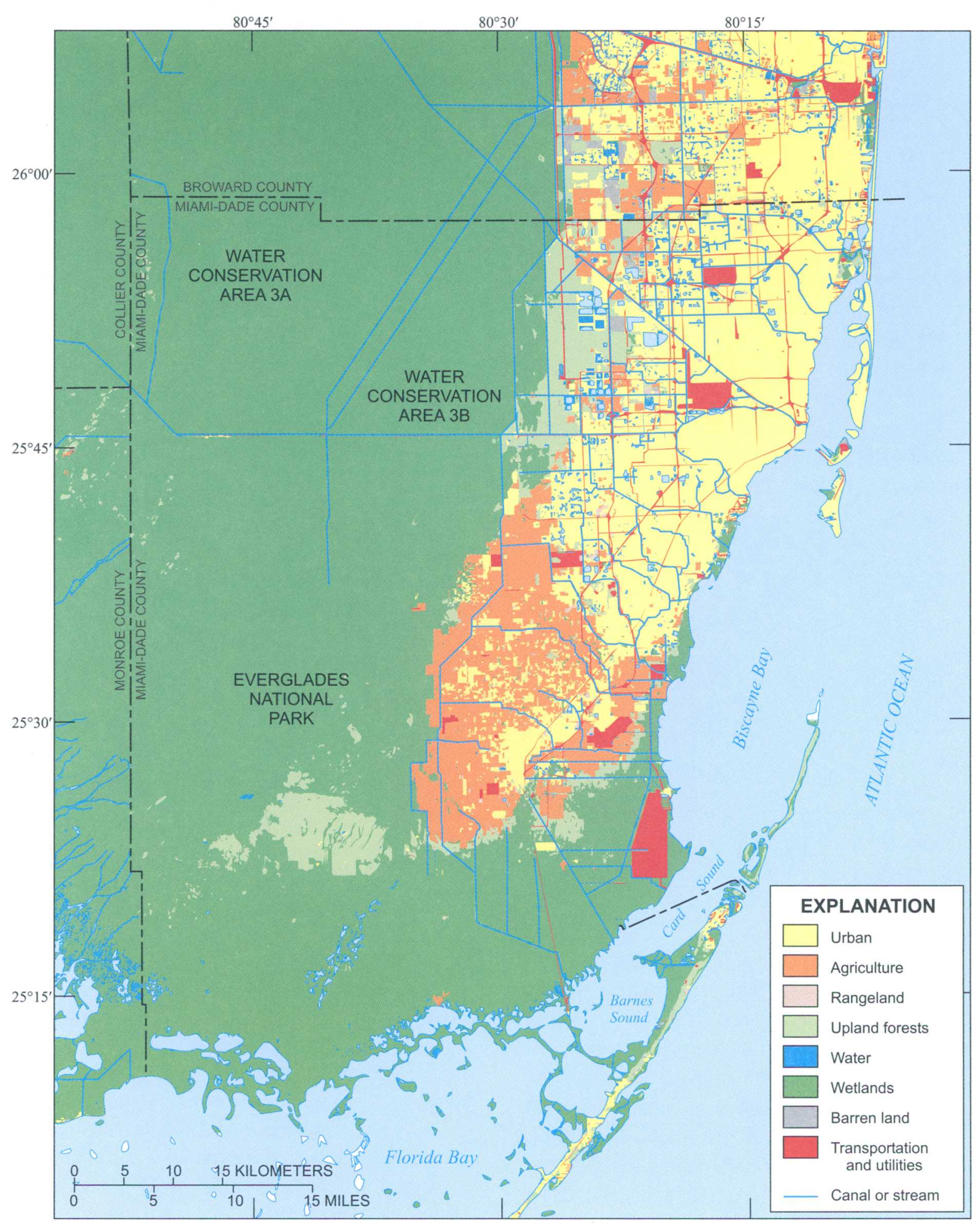

Figure 23. Land use of southern Florida for 1995. 
and extinction depth (EXTD). When the elevation of the water table is above the SURF elevation, the evapotranspiration rate is equal to QMAX. When the depth to the water table is greater than EXTD, the evapotranspiration rate is zero. When the water table is between SURF and EXTD, the evapotranspiration rate is linearly calculated between QMAX and zero. The SURF value assigned to each model cell is equal to the land-surface value. It is assumed that the extinction depth is related to land use (table 5; Restrepo and others 1992). The maximum evapotranspiration rates are assigned by month based on a study by Merritt (1996a). The monthly values for QMAX are listed in the table below. Evapotranspiration is not active for a model cell when a GHB (representing surface water) is active in that same cell. In that case, the effects of evapotranspiration are indirectly incorporated in the model through the specified stage of the GHB.

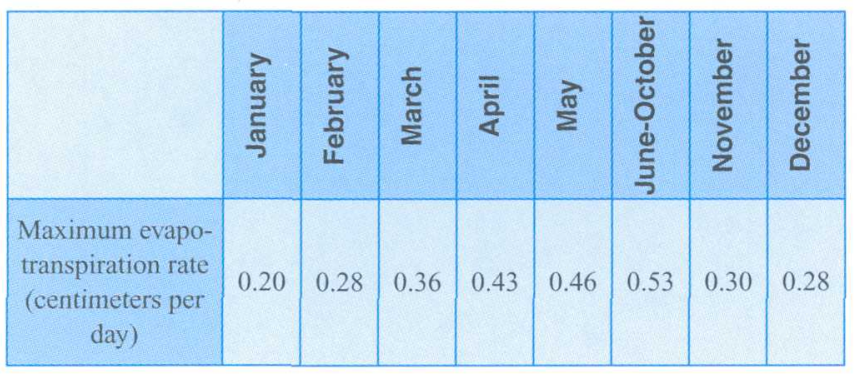

\section{Municipal Well Fields}

The effects of ground-water withdrawals from municipal well fields are included in the numerical model using the Well (WEL) package in SEAWAT. Pumpage was assigned to the model by well field rather than by pumping well. Each well field was assigned to a single cell in the model based on wellfield location and the open-hole interval of the pumping wells (pl. 3). In general, this simplification is reasonable because most of the pumping wells for a well field are contained within one model cell. Additionally, the model is not designed to characterize flow patterns at the well-field scale. Average values of monthly pumping rates for each well field were obtained from South Florida Water Management District (Water Use Division, written commun., 1999) and from Bertha Goldberg (Miami-Dade Water and Sewer Department, written commun., 1999). These pumping rates were assigned as monthly averages to the appropriate cells in the model.

\section{Initial Conditions}

Initial water levels were specified for the model by creating a TIN of the average water-table surface for January 1989. The TIN was generated using stage data from canals and water-level elevations from monitoring wells. Initial heads were assigned to each cell and layer in the model by interpolating values to the cell centers from the TIN of the water table.

Early attempts to specify initial concentrations consisted of specifying seawater concentrations $\left(35 \mathrm{~kg} / \mathrm{m}^{3}\right)$ east of the 1995 saltwater intrusion line (Sonenshein, 1997) and freshwater concentrations west of the saltwater intrusion line. This procedure was used for each layer and results in a vertical wall of seawater at the 1995 saltwater intrusion line. Results from early simulations suggested that a better estimate for initial salinity concentrations would reduce the length of simulation time required to achieve a stable position for the saltwater interface, thus increasing the length of time model results would be unaffected by the initial salinity distribution. The initial salinity distribution was improved by linearly interpolating concentrations between the 1995 saltwater intrusion line and Biscayne Bay. The initial salinity distribution was further improved by incorporating the results from the airborne geophysical survey (fig. 11; Fitterman and Deszcz-Pan, 1998) for the southern part of the model area.

\section{Calibration Procedure and Model Results}

Calibration is a procedure of adjusting input parameters until the model is a reasonable representation of the physical system. For this study, calibration was achieved by adjusting the input parameters for the model within a reasonable range until simulated values of head, canal baseflow, net recharge, and position of the saltwater interface approximated values observed in the field. In addition to these quantitative comparisons, the general flow patterns simulated by the model were qualitatively inspected to ensure that the model reasonably represents ground-water discharge to Biscayne Bay. To ensure that the variabledensity component of the model was working properly, special attention was focused on the cyclic flow patterns that result within the saltwater interface.

\section{Comparison of Simulated and Observed Heads}

Ground-water models traditionally are calibrated by matching simulated heads with water levels 
recorded in ground-water monitoring wells. Although this approach was used in this study, caution is exercised in evaluating the comparison because simulated and observed heads tend to match even when inappropriate aquifer parameters are used in the simulation. This potential problem results from two related conditions unique to the study area: (1) most of the model is overlain by hydrologic boundaries (canals and standing water in the Everglades), and (2) the hydraulic conductivity of the Biscayne aquifer is so high that the simulated heads are primarily controlled by boundary heads. Nevertheless, a reasonable match between observed and simulated heads is required for calibration, though a reasonable match does not ensure that the model is adequately calibrated.

Three different error statistics are commonly used to evaluate the comparison between observed and simulated values of head or other model variable (Anderson and Woessner, 1992). The mean error (ME) is simply the average of the differences between observed and simulated heads. Although the ME is a useful statistic, an ME value of zero does not indicate a perfect match between observed and simulated because positive and negative errors can average to zero. The mean absolute error (MAE) is calculated by taking the average of the absolute values of the differences between observed and simulated heads. The MAE may be the most useful statistic because it provides a true measure of the average difference between observed and simulated heads. The root-mean square error (RMSE) is calculated by taking the square root of the average of the squared differences. The RMSE is useful because it evaluates the spread of the errors by approximating the standard deviation of the errors.

The error statistics can be calculated in a variety of ways. For example, error statistics can be calculated for the differences by well and stress period, the differences for each well, or the differences for each stress period. The ME in head for all stress periods and wells $(6,525$ values in total) is $0.08 \mathrm{~m}$. The positive value for ME indicates that simulated values of head generally are higher than observed values of head. The MAE is $0.15 \mathrm{~m}$, which is an acceptable value considering that observed heads range from -2.23 to $2.51 \mathrm{~m}$. This means that the MAE relative to the range in observed heads is about 3 percent. The RMSE is $0.27 \mathrm{~m}$, indicating that about 68 percent of the head differences are within plus or minus $0.27 \mathrm{~m}$ of the ME. A histogram constructed from the differences between observed and simulated heads suggests that the differences are normally distributed with a mode of about $0.05 \mathrm{~m}$.

The locations of monitoring wells used in the comparison between observed and simulated heads are shown in figure 24 . Before head differences were calculated, the simulated heads were converted from freshwater head. In general, the ME is randomly distributed throughout the model domain (fig. 24). Wells near the coast tend to have an ME value that is relatively small, suggesting that simulated flow patterns near the coast are probably reasonable. To illustrate the level of calibration between observed and simulated values of head, the comparison is also presented as time-series plots for selected monitoring wells along the coast (fig. 25). These time-series plots, organized from north to south, illustrate the capability of the model to reasonably simulate head and fluctuations in head. A time-series plot of the error statistics also provides insight into the temporal distribution of error between observed and simulated heads (fig. 26). Errors tend to be large during the wet season and wet years (fig. 26).

\section{Comparison of Simulated and Observed Canal Baseflow}

Calibration of the ground-water flow model requires a reasonable match between observed and simulated values of canal baseflow, which is defined as the discharge of ground water to a canal. Canal baseflow can be positive or negative depending on location and the time of year. Matching canal baseflow is a required part of the calibration process because simulated and observed volumetric flow rates, rather than values of head, are compared. In the Biscayne aquifer where values of hydraulic conductivity are high, heads are relatively easy to match with a groundwater flow model. Matching baseflows, however, is much more difficult to achieve, but doing so results in a more reliable model.

Hydrologists divide study areas into smaller areas called surface-water basins. Runoff within a surface-water basin typically flows into a major river or canal and then exits the basin at a discrete outflow point. The surface-water basins shown in figure 27 were delineated for southeastern Florida by Cooper and Lane (1987).

Calibration of the regional-scale model to canal baseflow was performed for selected surface-water basins. For each of these basins, simulated baseflow was combined with the total runoff value estimated 


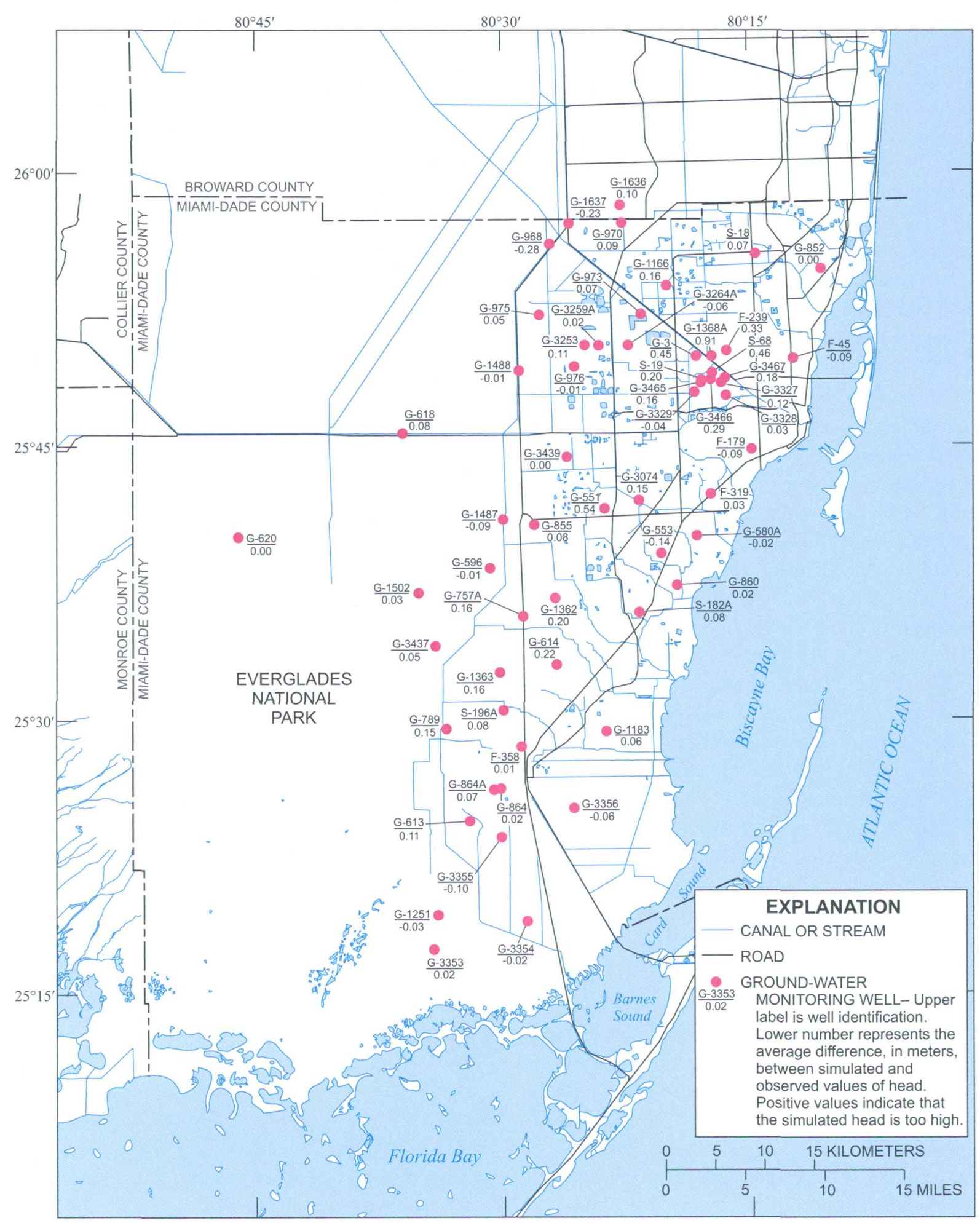

Figure 24. Location of ground-water monitoring wells in southern Florida used to calibrate the regional-scale ground-water flow model and average differences between observed and simulated values of head. 

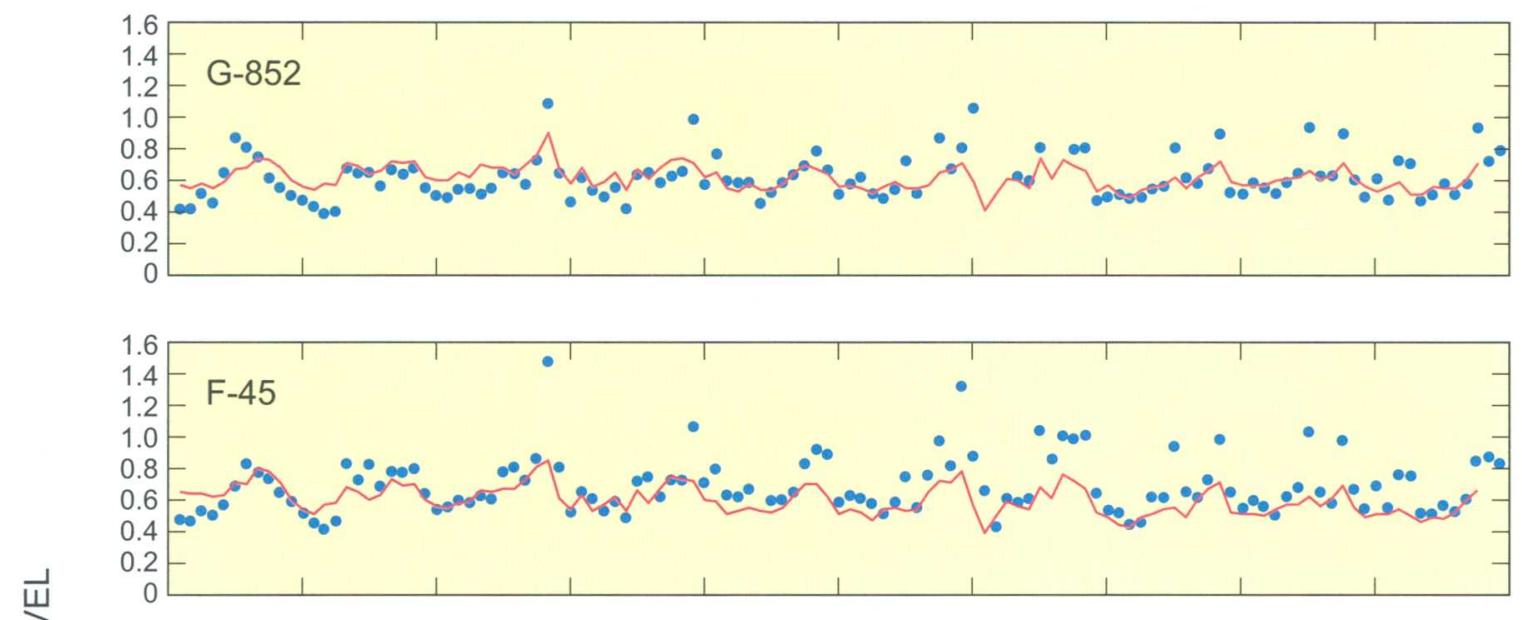

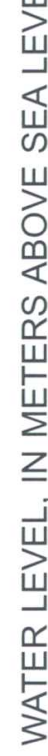

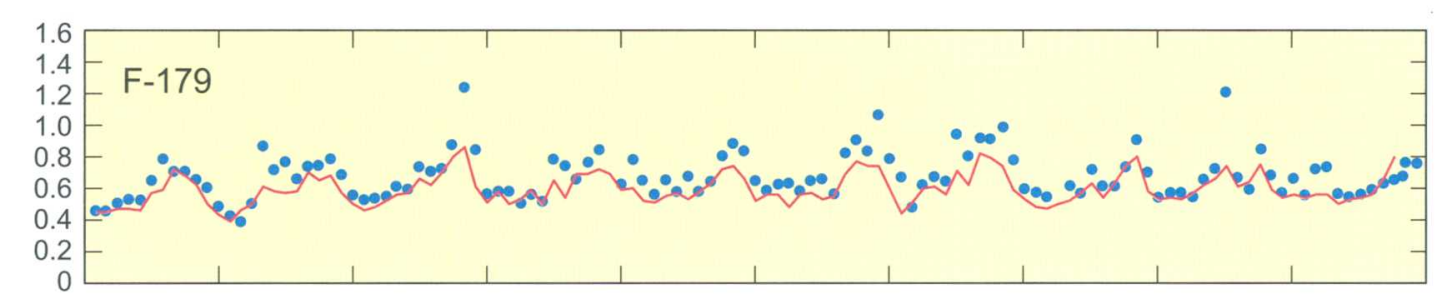

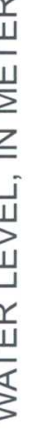
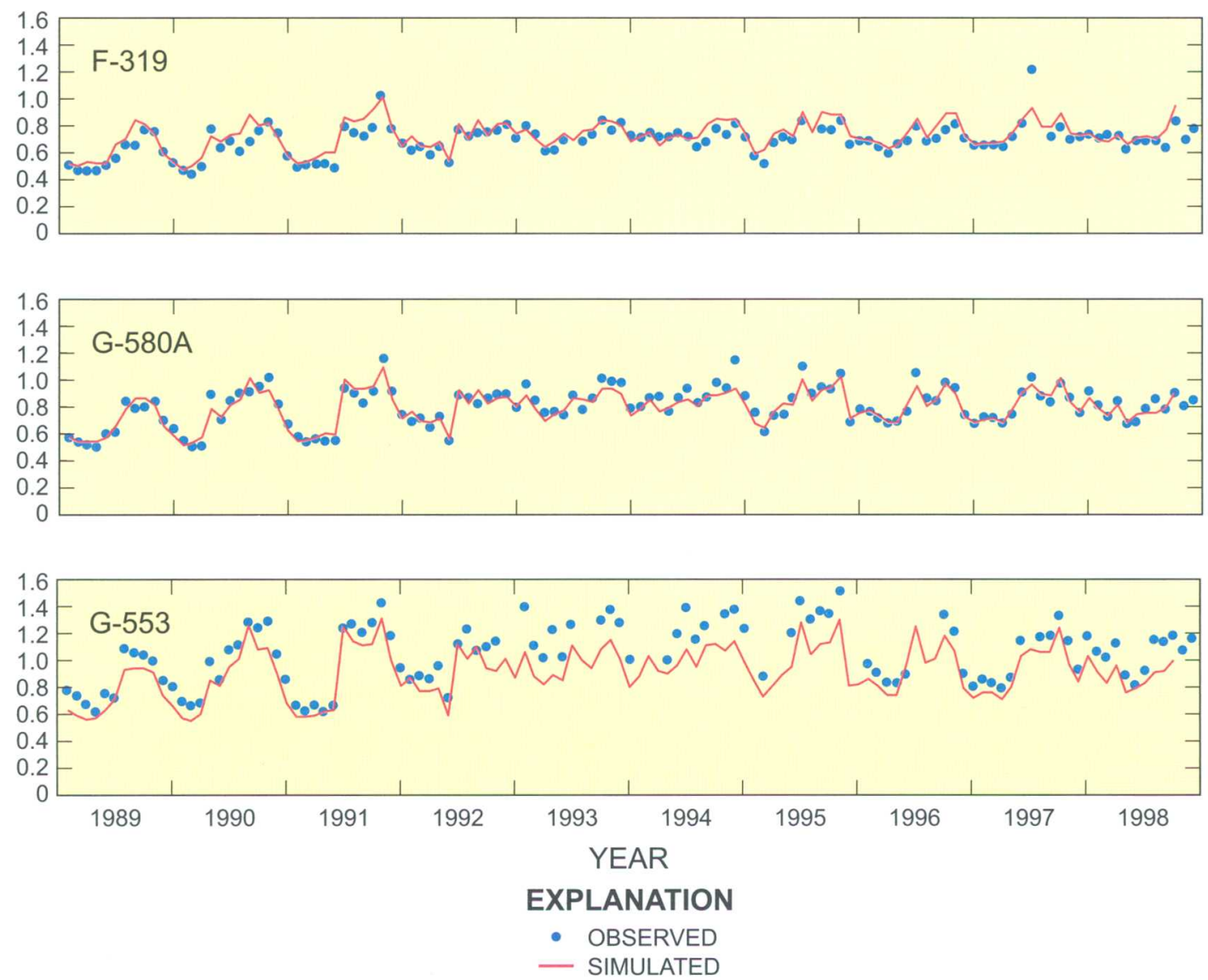

Figure 25. Comparison between observed and simulated monthly average heads for selected monitoring wells near the coast. 

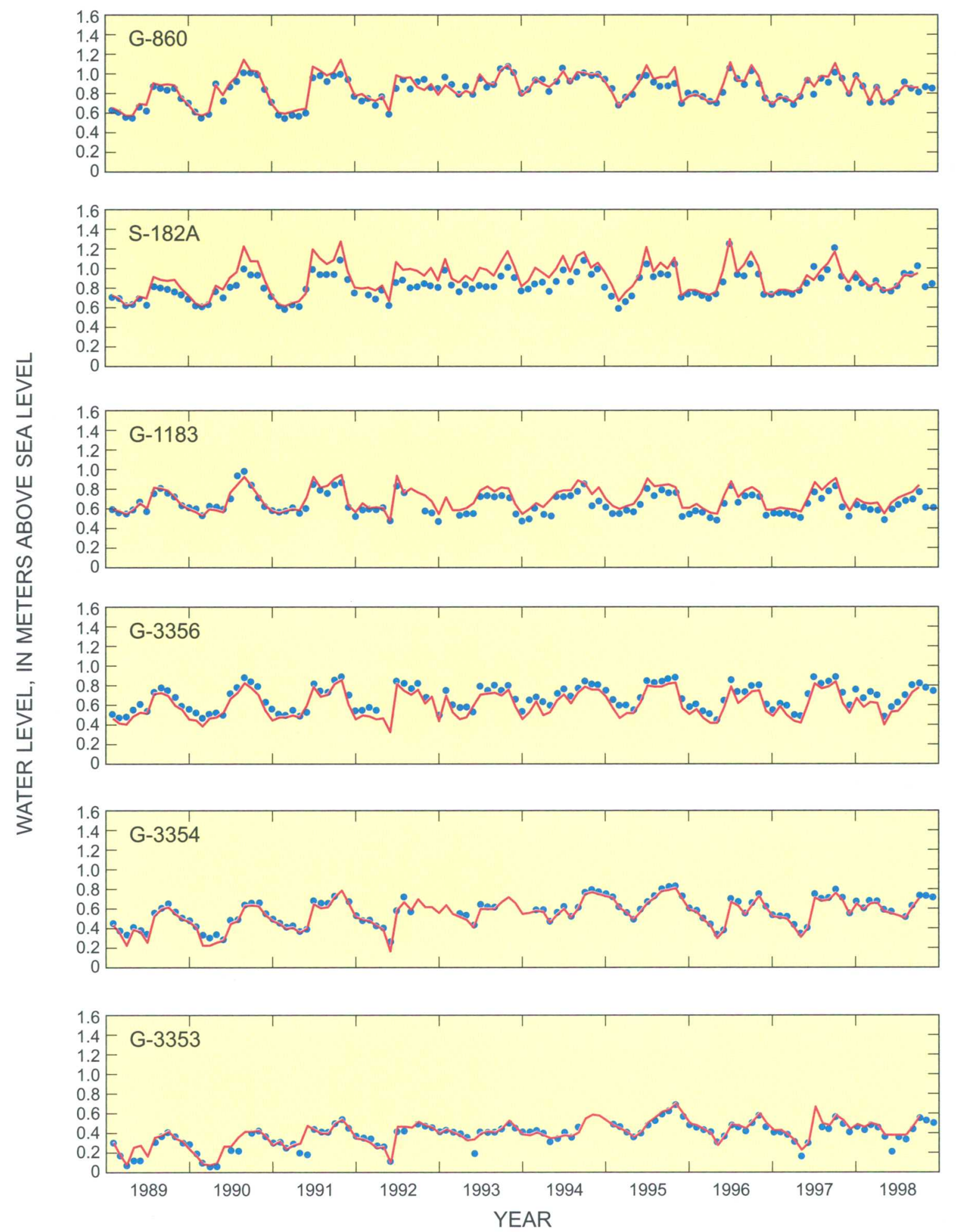

\section{EXPLANATION}

- OBSERVED

- SIMULATED

Figure 25. Comparison between observed and simulated monthly average heads for selected monitoring wells near the coast (continued). 


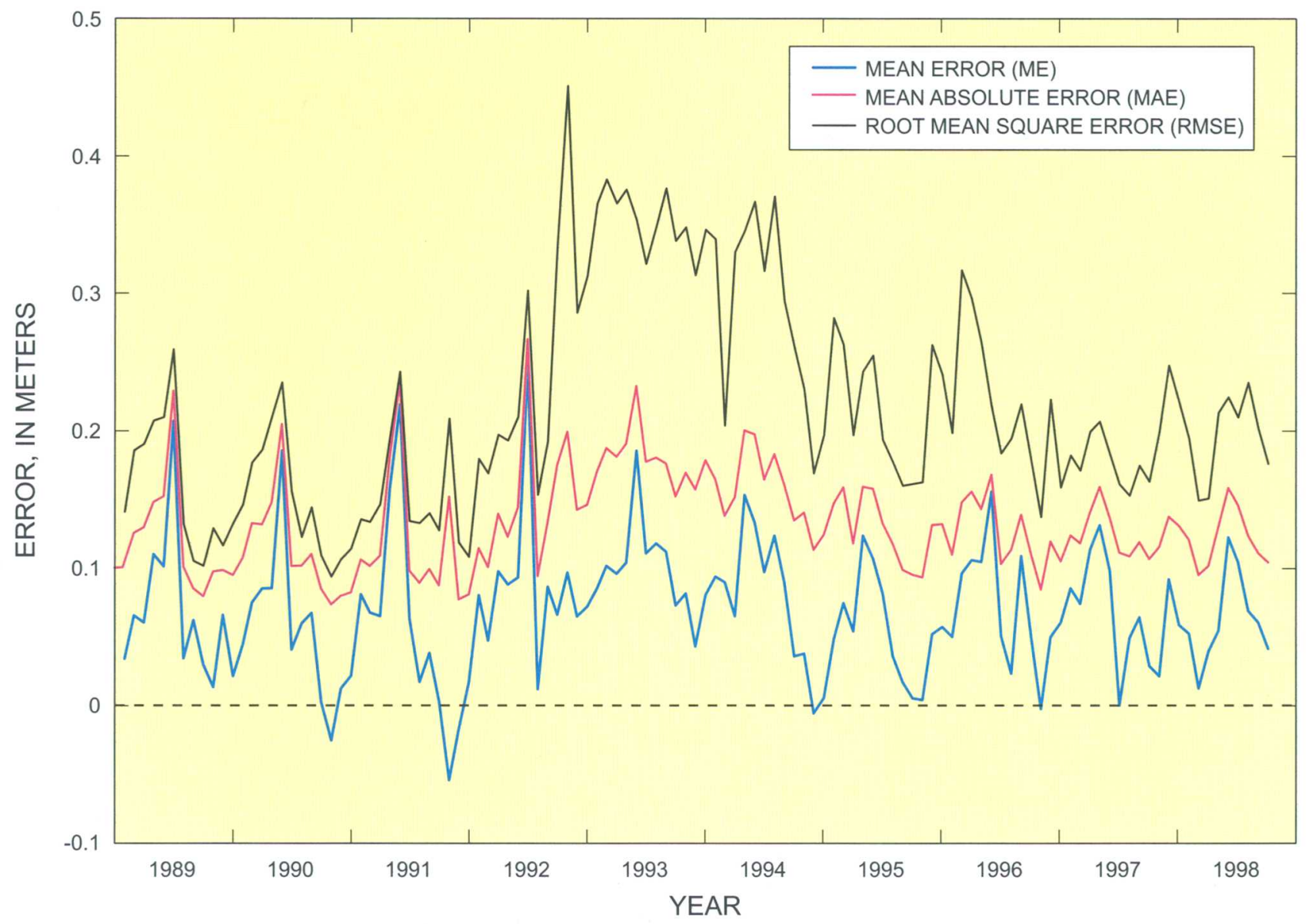

Figure 26. Calibration statistics for errors between observed heads and heads simulated by the regional-scale groundwater flow model.

from the land-use method described earlier. This combined value was then compared with the net canal loss or gain measured for the basin. Net losses and gains were calculated for the selected surface-water basins by subtracting canal inflows from canal outflows. It is assumed that the difference between inflow and outflow is equal to baseflow and runoff. The mathematical expression is:

$$
\text { Baseflow }+ \text { Runoff }=\text { Canal outflow }- \text { Canal inflow }
$$

where the left-hand-side is based on the simulation and the right-hand-side is based on measured quantities. Terms on the right side of the equation were obtained from the database of the South Florida Water Management District. Canal outflow is the sum of all surface-water discharge that flows out of the surface- water basin. Canal inflow is the sum of all surfacewater discharge that flows into the surface-water basin. This approach assumes that direct rainfall to a canal, direct evaporation from a canal, and storage within a canal are negligible.

The calibration to canal baseflow was achieved by adjusting conductance values for the RIV cells. Plots showing a comparison between observed and simulated values of canal baseflow (fig. 28) suggest the model reasonably simulates the dynamic exchange of water between canals and the Biscayne aquifer. The plots in figure 28 , organized from north to south, suggest that the model is reasonably capable of simulating the complex transfer of water between canals and the aquifer. Error statistics for the comparisons are included in figure 27. 


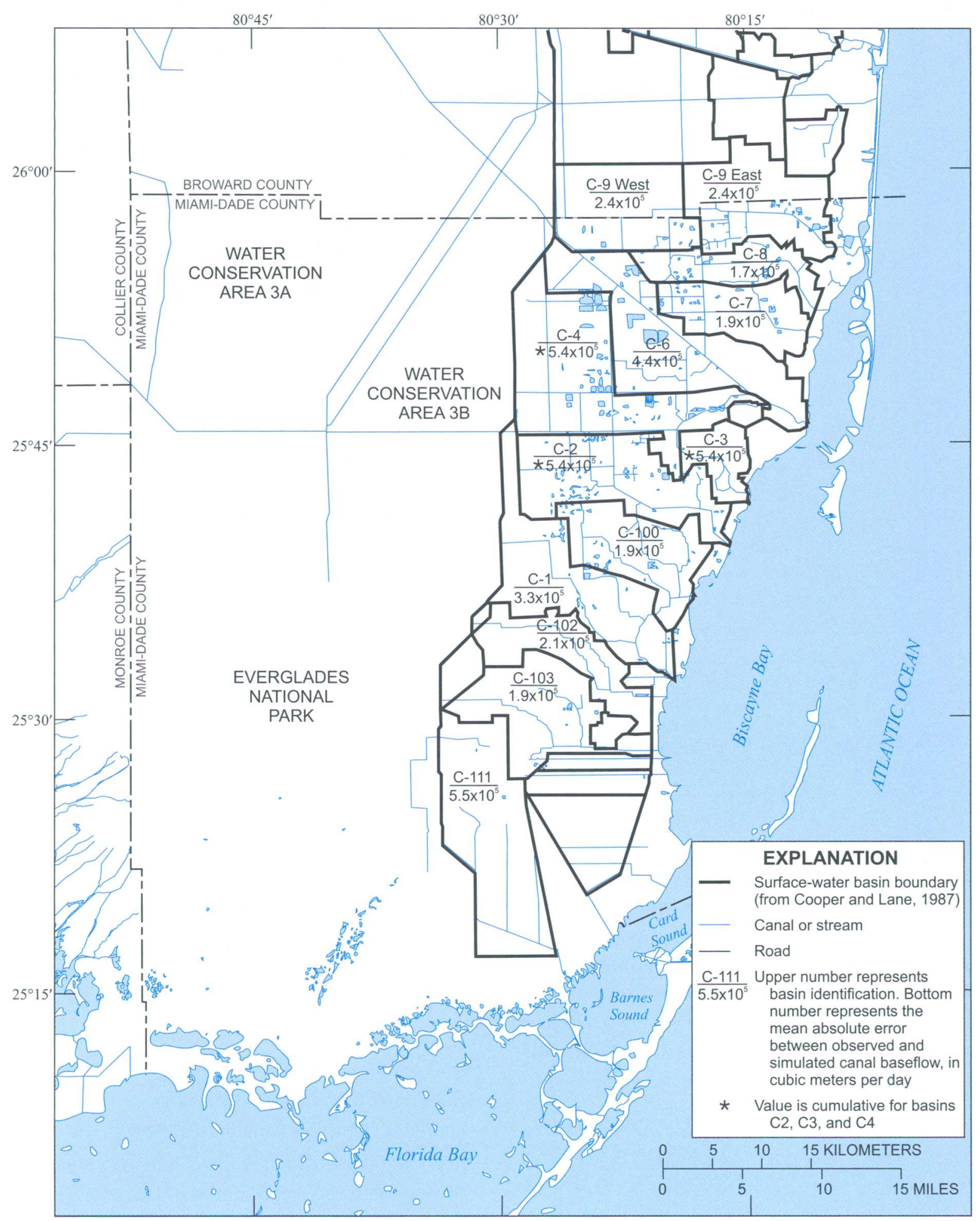

Figure 27. Location of surface-water basins in southern Florida and the mean absolute error between observed and simulated canal baseflow. 


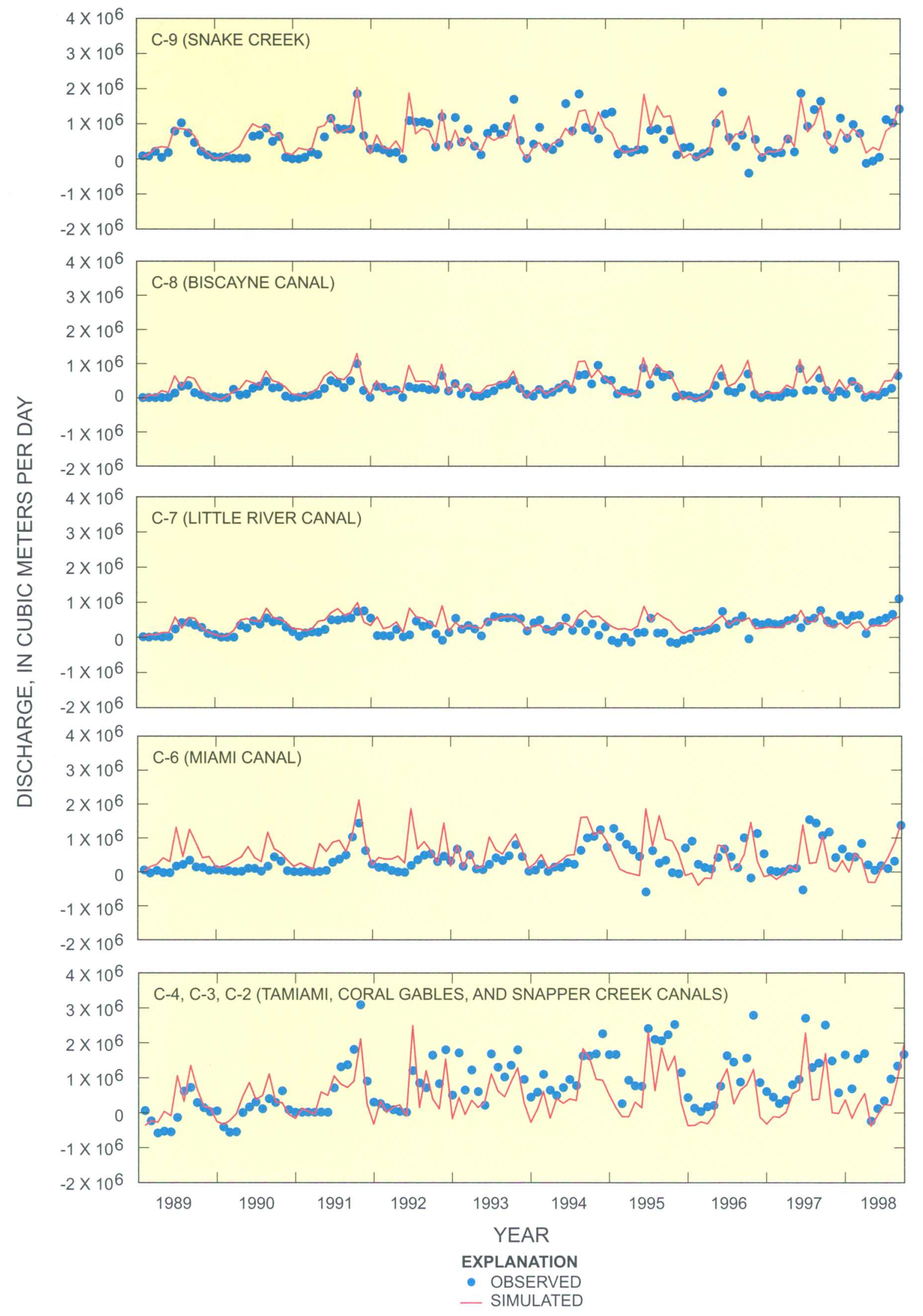

Figure 28. Comparison between observed and simulated values of monthly average canal baseflow for selected surface-water basins. Negative values indicate that the net flow was from the canal into the aquifer. 


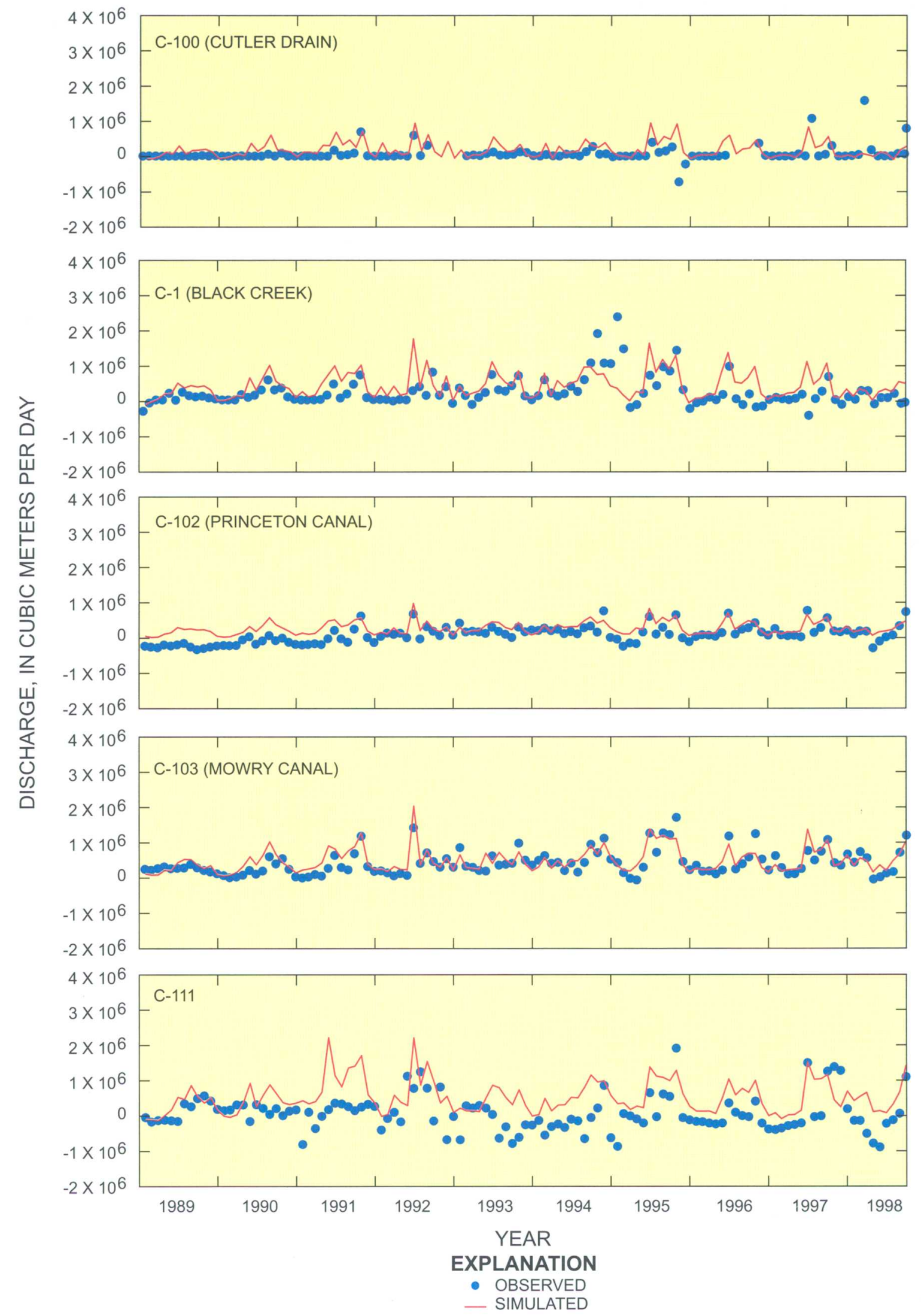

Figure 28. Comparison between observed and simulated values of monthly average canal baseflow for selected surface-water basins (continued). Negative values indicate that the net flow was from the canal into the aquifer. 


\section{Net Recharge}

Net recharge is generally described as the percentage of rainfall that reaches the water table after runoff and evapotranspiration are withdrawn. Since evapotranspiration is a function of the water-table elevation in the model, the rate of net recharge actually is a result of the simulation. The simulated rates of recharge, therefore, must be inspected to ensure that values are within a reasonable range. This is particularly true for the regional-scale model because net recharge is a large component of the water budget.

A subroutine was added to the SEAWAT code to save net recharge rates by transport step. A postprocessing code was then used to calculate the average value of net recharge for each cell based on the entire simulation period. Net recharge was calculated by combining rainfall, evapotranspiration, and discharge to or from a GHB representing surface water in the Everglades. The spatial distribution of average annual net recharge for the simulation period is illustrated in figure 29. Net recharge rates are expressed in centimeters per year to facilitate a direct comparison with the average annual rainfall rate of $141 \mathrm{~cm} / \mathrm{yr}$. Results suggest that the regional-scale model reasonably simulates the spatial distribution of net recharge. High recharge values are located along the Atlantic Coastal Ridge (fig. 2) where the water table is the deepest. In the Everglades and water-conservation areas, the model simulates moderate recharge values (fig. 29). Negative values of net recharge indicative of high evapotranspiration rates and ground-water discharge areas are simulated in the low-lying areas along the southeastern part of the model domain.

\section{Saltwater Interface}

For the regional-scale model to accurately simulate the discharge of ground water to Biscayne Bay, the model must accurately simulate the threedimensional distribution of ground-water salinity. Unfortunately, data are lacking to adequately characterize the three-dimensional distribution of groundwater salinity because most monitoring wells are installed near the toe of the saltwater interface rather than within the transition zone. The observed data provide a two-dimensional description of the position of the saltwater interface. Rather than compare the few point measurements of ground-water salinity with simulated values of salinity, model results are reduced to two dimensions to facilitate a comparison with the 1995 position of the saltwater intrusion line
(Sonenshein, 1997). In figure 30, the simulated salt concentrations in the lowermost active model cell are shaded according to their corresponding salinity values. Salinities in the lowermost active model cells are the most appropriate model results to use in the comparison with the observed 1995 saltwater intrusion line because the line was drawn for the base of the Biscayne aquifer.

In general, the model reasonably simulates the position of the saltwater interface, particularly south of the Miami Canal. North of the Miami Canal, the simulated position of the saltwater interface extends too far inland by 5 to $10 \mathrm{~km}$. Three possible explanations for the discrepancy between observed and simulated positions of the saltwater interface for the area north of Miami Canal include: (1) the aquifer parameters and hydrologic stresses do not accurately represent the physical system, (2) numerical dispersion has caused the transition zone to spread too far inland, and (3) the observed position of the 1996 saltwater intrusion line is in disequilibrium with the current hydrologic stresses, but with time will migrate inland to the position simulated by the model.

Aquifer parameters and hydrologic stresses that did not accurately represent the physical system seem to be the most likely explanation for the discrepancy. Simulated heads at monitoring wells G-852 and F-45 generally are too low (fig. 25), suggesting that the hydrologic stresses or aquifer parameters used in the model may be in error. By improving the model in this area, the simulated position of the saltwater interface probably would more closely approximate the observed position of the saltwater interface.

To test the second possible explanation for the discrepancy (numerical dispersion), hypothetical, cross-sectional models with different levels of discretization were run with SEAWAT. The cross-sectional model with resolution similar to that of the regionalscale model (1,000 $\mathrm{m}$ horizontal by $5 \mathrm{~m}$ vertical) gave results identical to those from a much more detailed model ( $200 \mathrm{~m}$ horizontal by $1 \mathrm{~m}$ vertical), suggesting that numerical dispersion probably does not significantly affect the regional-scale model.

The third possible explanation for the discrepancy (disequilibrium) also is unlikely. Chloride concentrations in monitoring wells north of the Miami Canal do not show a long-term increasing trend, which suggests that the current position of the saltwater interface is in equilibrium with the current hydrologic stresses. 


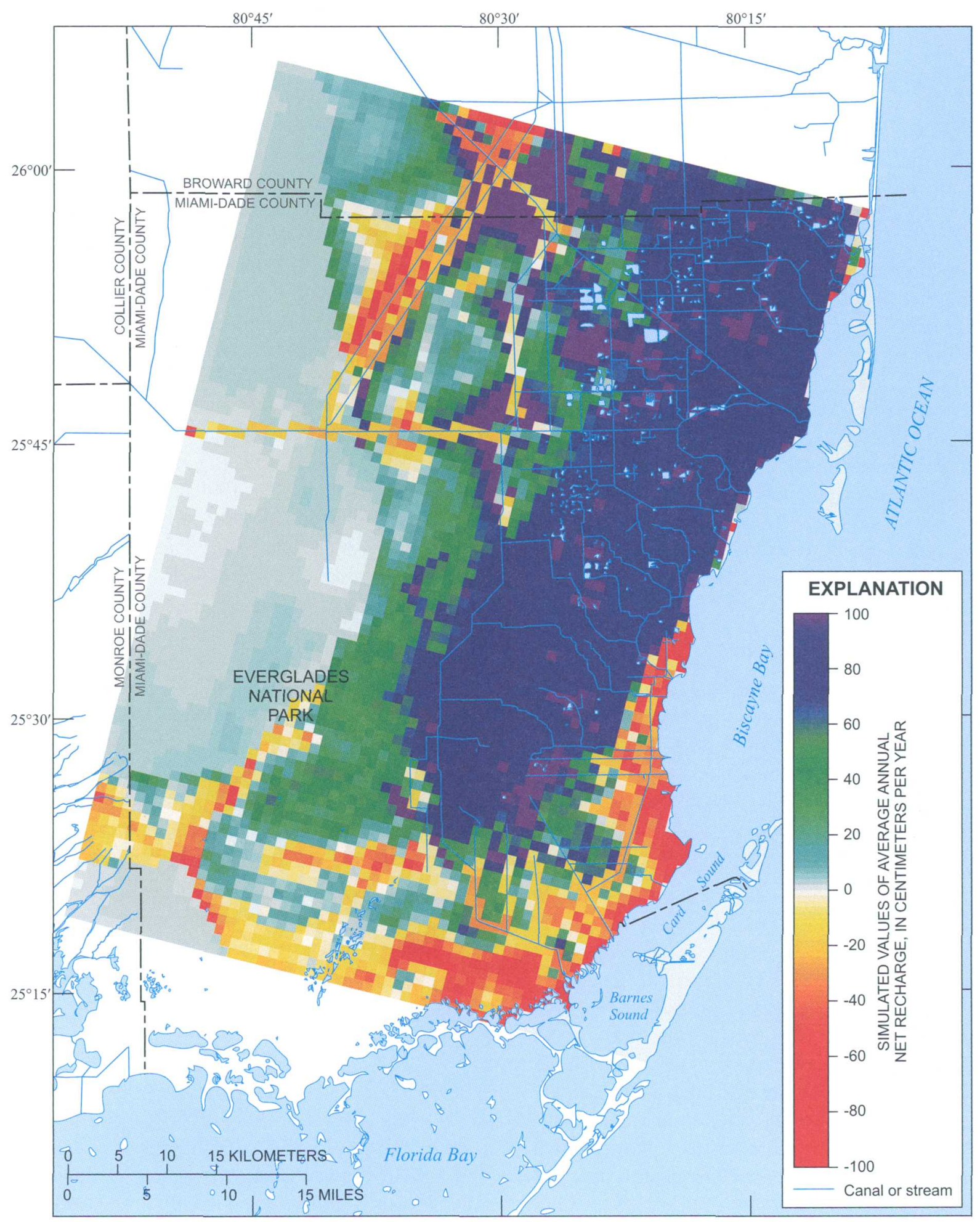

Figure 29. Simulated values of average annual net recharge from the regional-scale ground-water flow model for 1989-98. 


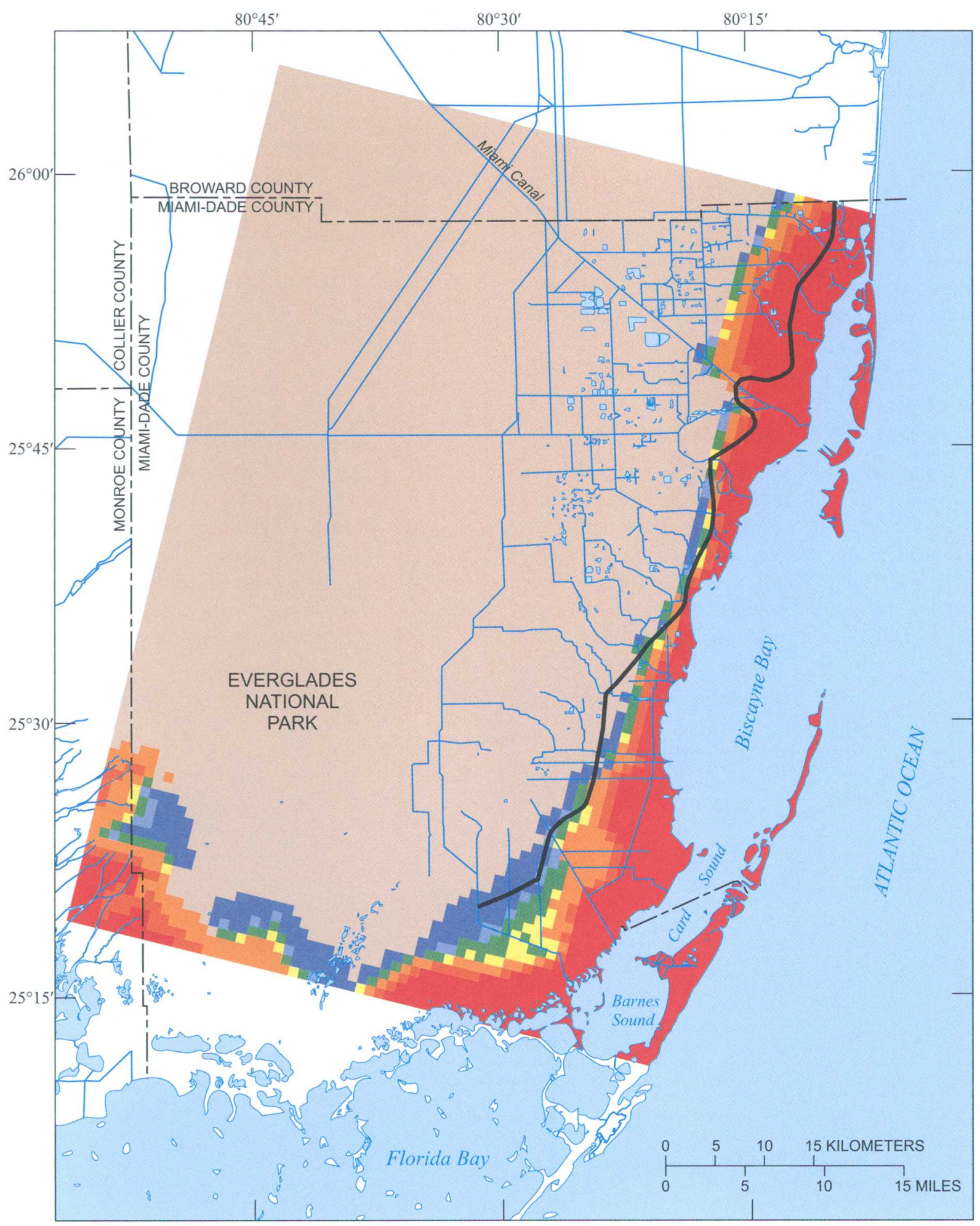

\section{EXPLANATION}

SIMULATED VALUE OF GROUND-WATER SALINITY, IN KILOGRAMS PER CUBIC METER

$0-0.01$

$>0.01-0.05$

$>0.05-0.1$

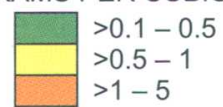

$>1-5$ $\longrightarrow$ Lake

Canal or stream

1995 saltwater intrusion line (Sonenshein, 1997)

Figure 30. Simulated values of ground-water salinity at the base of the Biscayne aquifer compared with the 1995 saltwater intrusion line. 
A plot of total salt mass in the aquifer relative to time suggests that the initial salt concentrations in the model are too low (fig. 31). However, as the simulation progresses through time, the total salt mass in the aquifer generally increases, with slight decreases during the wet seasons. Toward the end of the simulation, it appears that the model approaches steady state with respect to salt mass in the model domain. The plot of total salt mass suggests that the ground-water salinities simulated by the model are approaching equilibrium with the hydrologic stresses and aquifer parameters used in the model. Results from early in the simulation period should be evaluated with caution because initial ground-water salinities probably are too low.

\section{Ground-Water Flow to Biscayne Bay}

The simulated ground-water flow from the active model cells into the coastal constant-head cells is assumed to represent the discharge of ground water to Biscayne Bay. In addition, to simulating the volumetric flow rate, the model also simulates the salt concentration of the ground-water flow into the constanthead cells. This salt concentration is assumed to represent the salinity of the ground water that discharges to Biscayne Bay. The simulated salinity of ground-water discharge to Biscayne Bay ranges from nearly fresh at the shoreline to nearly seawater some distance offshore. To simplify the results, simulated discharge estimates are presented as the freshwater portion of the total discharge. The freshwater portion of the ground-water discharge is calculated from the total discharge using the following equation,

$$
Q_{f}=Q_{T}\left(\frac{\rho_{s}-\rho}{\rho_{s}-\rho_{f}}\right)
$$

where:

$Q_{f}$ is fresh ground-water discharge, in cubic meters per day,

$Q_{T}$ is total ground-water discharge, in cubic meters per day,

$\rho_{s}$ is fluid density of pure seawater, in kilograms per cubic meter,

$\rho$ is simulated fluid density of ground water discharging to Biscayne Bay, in kilograms per cubic meter, and

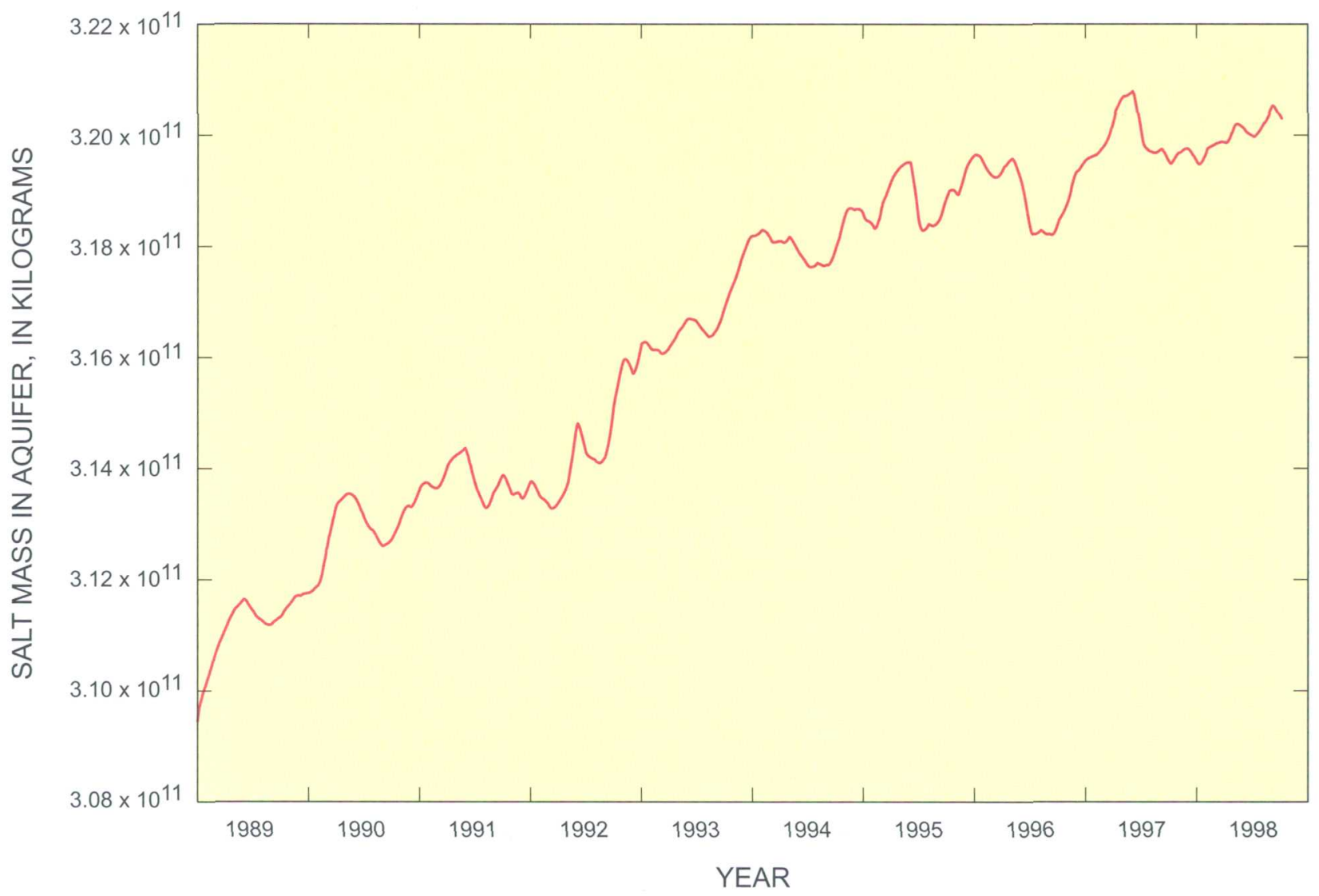

Figure 31. Total salt mass in the Biscayne aquifer as simulated by the regional-scale ground-water flow model. 
$\rho_{f}$ is fluid density of pure freshwater, in kilograms per cubic meter.

When the fluid density of the ground-water discharge is equal to $1,000 \mathrm{~kg} / \mathrm{m}^{3}$, the fresh ground-water discharge is equal to the total ground-water discharge. When the fluid density of the ground-water discharge is equal to the fluid density of seawater $\left(1,025 \mathrm{~kg} / \mathrm{m}^{3}\right)$, the fresh ground-water discharge is equal to zero. During certain times, simulated flow is from the bay into the aquifer. When this condition occurs, $Q_{T}$ is negative, but $Q_{f}$ is zero. A subroutine was added to SEAWAT to calculate and sum the $Q_{T}$ and $Q_{f}$ terms between each constant-head cell and the adjacent active cells. These flow terms are written to a file following each timestep. At the end of a model run, a post-processing routine calculates the average flows for each constanthead cell by stress period.

One potential problem with calculating fresh ground-water discharge estimates from simulated density is that the resulting freshwater discharge quantities are directly dependent on salt concentrations. (Density is a linear function of salt concentration.) As previously mentioned, ground-water salinities are consid- ered calibrated when the simulated position of the saltwater interface matches the observed position of the saltwater interface. This does not ensure that the simulated salt concentrations are calibrated. The average salt concentration of simulated discharge to Biscayne Bay is about half that of seawater, and thus half of the total discharge is freshwater. This suggests that if salt concentrations are in error by 100 percent $\left(17.5 \mathrm{~kg} / \mathrm{m}^{3}\right)$, estimates of fresh ground-water discharge would be in error by about a factor of two.

Results from the regional-scale model indicate that fresh ground-water discharge to Biscayne Bay occurs along the coastline and into the tidal portions of the Miami, Coral Gables, and Snapper Creek Canals (fig. 32). The model suggests that fresh ground-water discharge at the coastline of Biscayne Bay is similar in magnitude to the fresh ground-water discharge to the tidal canals. The average rate of fresh ground-water discharge is about $2.2 \times 10^{5} \mathrm{~m}^{3} / \mathrm{d}$ for the coastline of Biscayne Bay, about $1.6 \times 10^{5} \mathrm{~m}^{3} / \mathrm{d}$ for the tidal portion of the Miami Canal, about $1.4 \times 10^{5} \mathrm{~m}^{3} / \mathrm{d}$ for the tidal portion of the Coral Gables Canal, and about $3.2 \times 10^{4} \mathrm{~m}^{3} / \mathrm{d}$ for the tidal portion of the Snapper

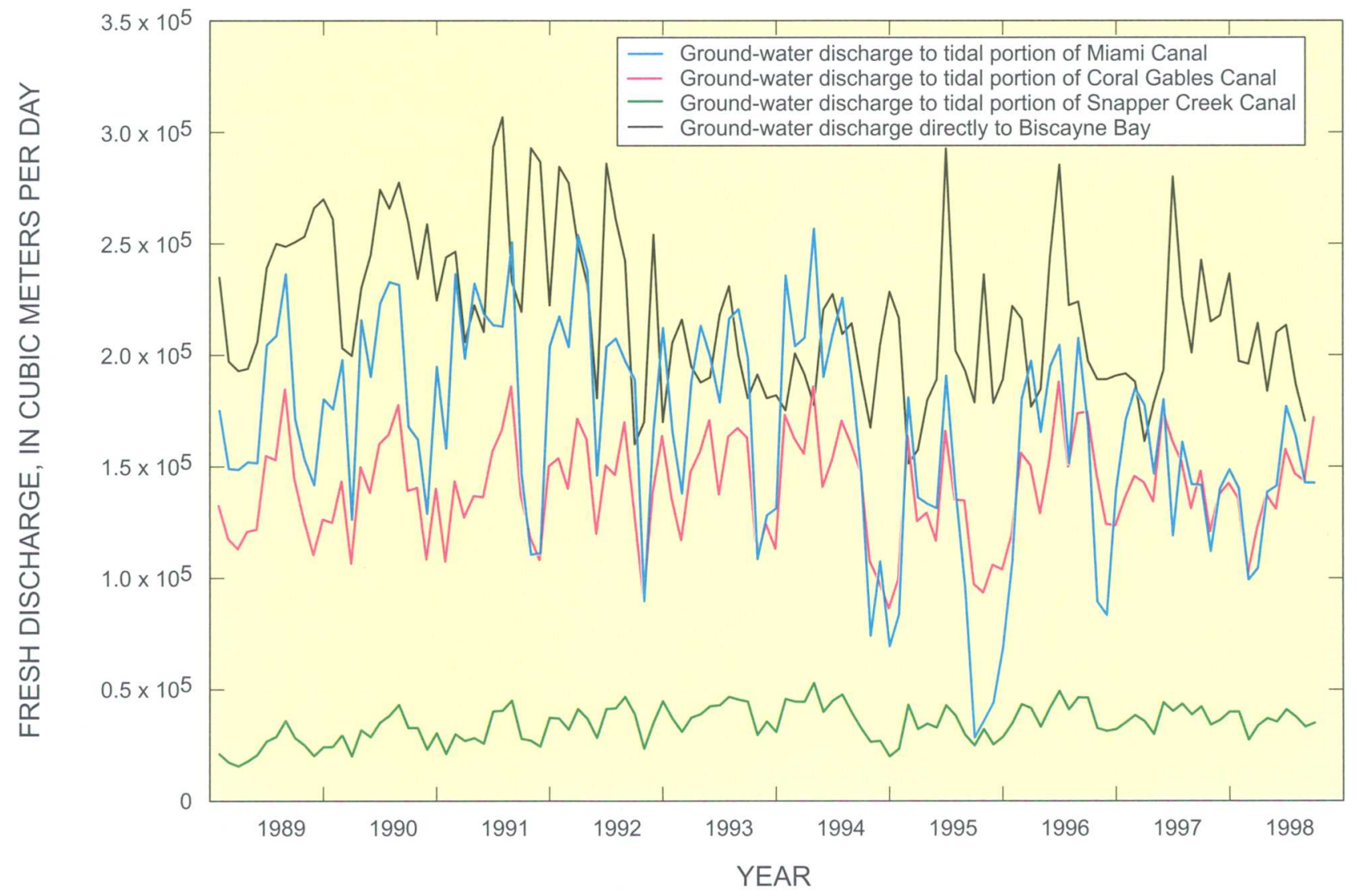

Figure 32. Simulated fresh ground-water discharge to Biscayne Bay. 
Creek Canal. The annual fluctuation in fresh groundwater discharge is about $1 \times 10^{5} \mathrm{~m}^{3} / \mathrm{d}$ for the coastline of Biscayne Bay and the tidal portions of the Miami and Coral Gables Canals and is about $3 \times 10^{4} \mathrm{~m}^{3} / \mathrm{d}$ for the tidal portion of the Snapper Creek Canal. Fluctuations in ground-water discharge appear to be damped because sea level was highest during the wet season when the water table was relatively high and lowest during the dry season when the water table was relatively low.

A comparison was made between simulated fresh ground-water discharge and measured surfacewater discharge from the coastal control structures (figs. 4 and 5, from S-29 to S-197). Based on the results for the simulation period (1989-98), fresh ground-water discharge seems to be an important mechanism of freshwater delivery to Biscayne Bay during the dry season (fig. 33). For the dry seasons of 1989, 1990, and 1991, model results suggest that fresh ground-water discharge exceeded the surface-water discharge to Biscayne Bay. During the wet season, however, fresh ground-water discharge is about one order of magnitude less than the surface-water discharge. For the total simulation period, groundwater discharge is about 6 percent of surface-water discharge.

Nearly 100 percent of the fresh ground-water discharge to Biscayne Bay is to the northern half of Biscayne Bay, north of structure S-123 (figs. 4 and 5). South of structure S-123, where land-surface elevations are less than $1 \mathrm{~m}$ above sea level, the water table was unable to develop enough head to drive groundwater discharge into the bay.

\section{Sensitivity Analysis}

A sensitivity analysis was performed with the regional-scale model to determine the effects of various boundary conditions and aquifer parameters on the simulated estimates of fresh ground-water discharge to Biscayne Bay. Boundary conditions that were evaluated in the sensitivity analysis include stage in Biscayne Bay and the type of solute-transport boundary used to represent Biscayne Bay. Aquifer parameters that were evaluated with the sensitivity analysis include horizontal hydraulic conductivity,

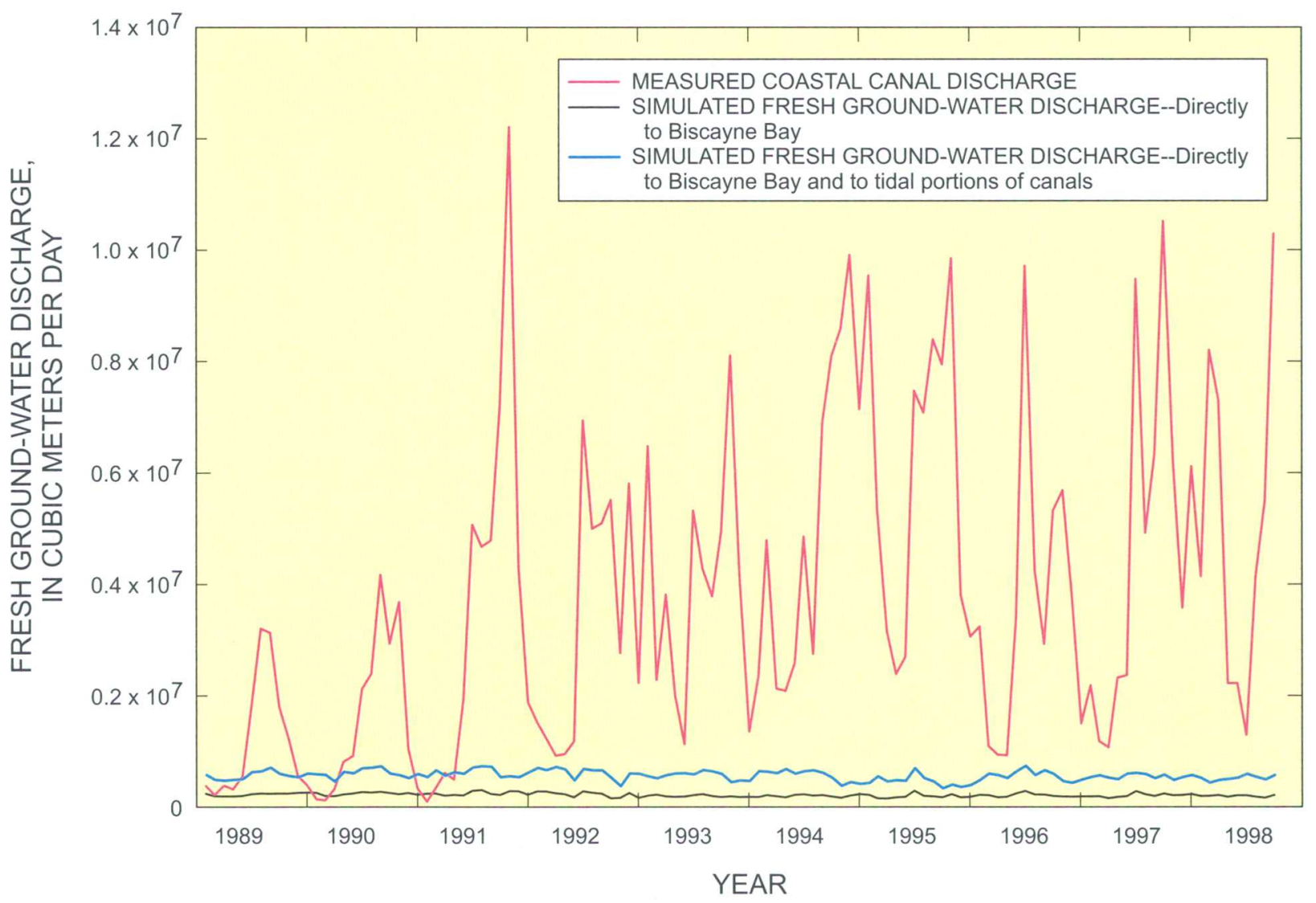

Figure 33. Simulated fresh ground-water discharge compared with measured surface-water discharge to Biscayne Bay. 
vertical conductance, dispersivity, and river conductance. Simulated values of freshwater discharge to Biscayne Bay do not appear to be sensitive to vertical conductance.

For the first sensitivity run, a different type of concentration boundary was used to represent Biscayne Bay. In addition to the constant-concentration boundary type, MT3D and SEAWAT have another solute-transport boundary type that may be appropriate for representing concentrations in Biscayne Bay. This other boundary type is referred to as specified concentration for inflow, which means that any fluid entering the active model domain has a specified concentration. With the constant-concentration boundary, salt mass is transferred from the boundary into the active model domain by advection and dispersion. With the specified concentration for inflow, however, salt mass is transferred only by advection. By specifying the concentration for inflow, the simulated concentration of the constant-head cell may be less than the actual concentration specified for inflow. Compared with the calibrated, regional-scale model (referred to in this section as the base case), using a specified concentration for inflow as the boundary type for Biscayne Bay increases the fresh ground-water discharge simulated by the model (fig. 34) by about a factor of two. The average discharge rate for the sensitivity run is $4.9 \times 10^{5} \mathrm{~m}^{3} / \mathrm{d}$ as compared with the average base case value of $2.2 \times 10^{5} \mathrm{~m}^{3} / \mathrm{d}$.

The effect of Biscayne Bay salinity was evaluated by running a simulation in which the salinity values assigned to the constant-concentration cells in layer 2 were specified using the results from a circulation model of Biscayne Bay, which represents the four years from 1995 to 1998 (John Wang, University of Miami, written commun., 2000). For this sensitivity run, the salinity values from the circulation model were repeated so that a 10 -year run could be performed with the regional-scale model and that the time period between the two models would align from 1995 to 1998 . The circulation model does not cover the northern part of Biscayne Bay. For this reason, the salinity value assigned to the northern part of Biscayne Bay remains unchanged from the base case. By using salinity values from the circulation model, the simulated value of fresh ground-water discharge to Biscayne Bay increases to about $3.7 \times 10^{5} \mathrm{~m}^{3} / \mathrm{d}$. A similar run was also performed in which a specified concentration for inflow boundary was used with salinity values from the circulation model. For this run, the average rate of fresh ground-water discharge to Biscayne Bay is $5.8 \times 10^{5} \mathrm{~m}^{3} / \mathrm{d}$. In both of these runs with the bay salinities set from results of the circulation model, the salinity values assigned to the constant-concentration cells in layer 2 may be less than the salinity of seawater, which means that Biscayne Bay contains a freshwater component. This freshwater component in Biscayne Bay, which is most likely from canal discharge, can be circulated downward into the aquifer. The rate of fresh submarine ground-water discharge determined by this sensitivity run, therefore, contains a freshwater component that results from salinity values in the bay that are less than the salinity of seawater.

The effect of stage in Biscayne Bay was evaluated by running two simulations in which the stage value for each month was increased or decreased by $0.25 \mathrm{~m}$. When the average monthly stage in Biscayne Bay increases by $0.25 \mathrm{~m}$, the simulated ground-water discharge decreases to an average value of $0.7 \times 10^{5} \mathrm{~m}^{3} / \mathrm{d}$. A decrease in the average monthly stage by $0.25 \mathrm{~m}$ substantially increases the ground-water discharge to an average value of $5.4 \times 10^{5} \mathrm{~m}^{3} / \mathrm{d}$. Results from this sensitivity analysis may be used to infer the effects of sea-level rise on ground-water discharge to Biscayne Bay.

A sensitivity analysis was completed to evaluate the effect of hydraulic conductivity on ground-water discharge to Biscayne Bay by performing two simulations. Hydraulic conductivity was increased by a factor of two for the first run; the simulated fresh groundwater discharge to Biscayne Bay increases to an average value of $3.7 \times 10^{5} \mathrm{~m}^{3} / \mathrm{d}$. By decreasing the hydraulic conductivity by a factor of two, the simulated ground-water discharge decreases to an average value of $1.3 \times 10^{5} \mathrm{~m}^{3} / \mathrm{d}$. These data suggest that for the values tested, an error in estimating hydraulic conductivity results in about a one-to-one error in estimates of fresh ground-water discharge to Biscayne Bay.

Results from a sensitivity analysis of aquifer dispersivity suggest that simulated rates of groundwater discharge are sensitive to the value of dispersivity used in the model. When the longitudinal and transverse values for dispersivity are increased by a factor of 10 , simulated rates of fresh ground-water discharge decrease (fig. 34). Conversely, when the longitudinal and transverse values for dispersivity are decreased by a factor of 10 , simulated rates of fresh ground-water discharge increase (fig. 34). 

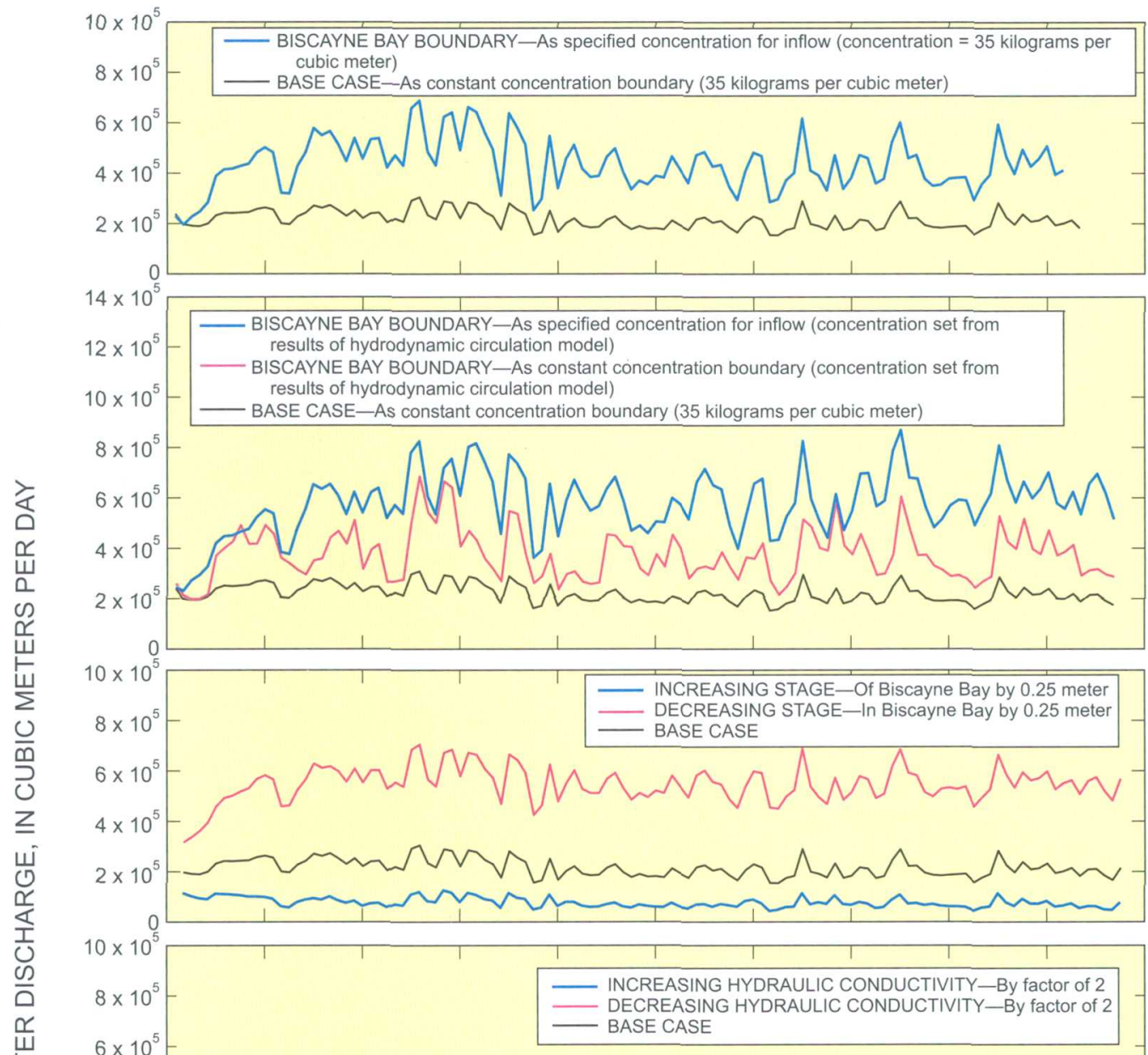

$4 \times 10^{5}$

$2 \times 10^{5}$
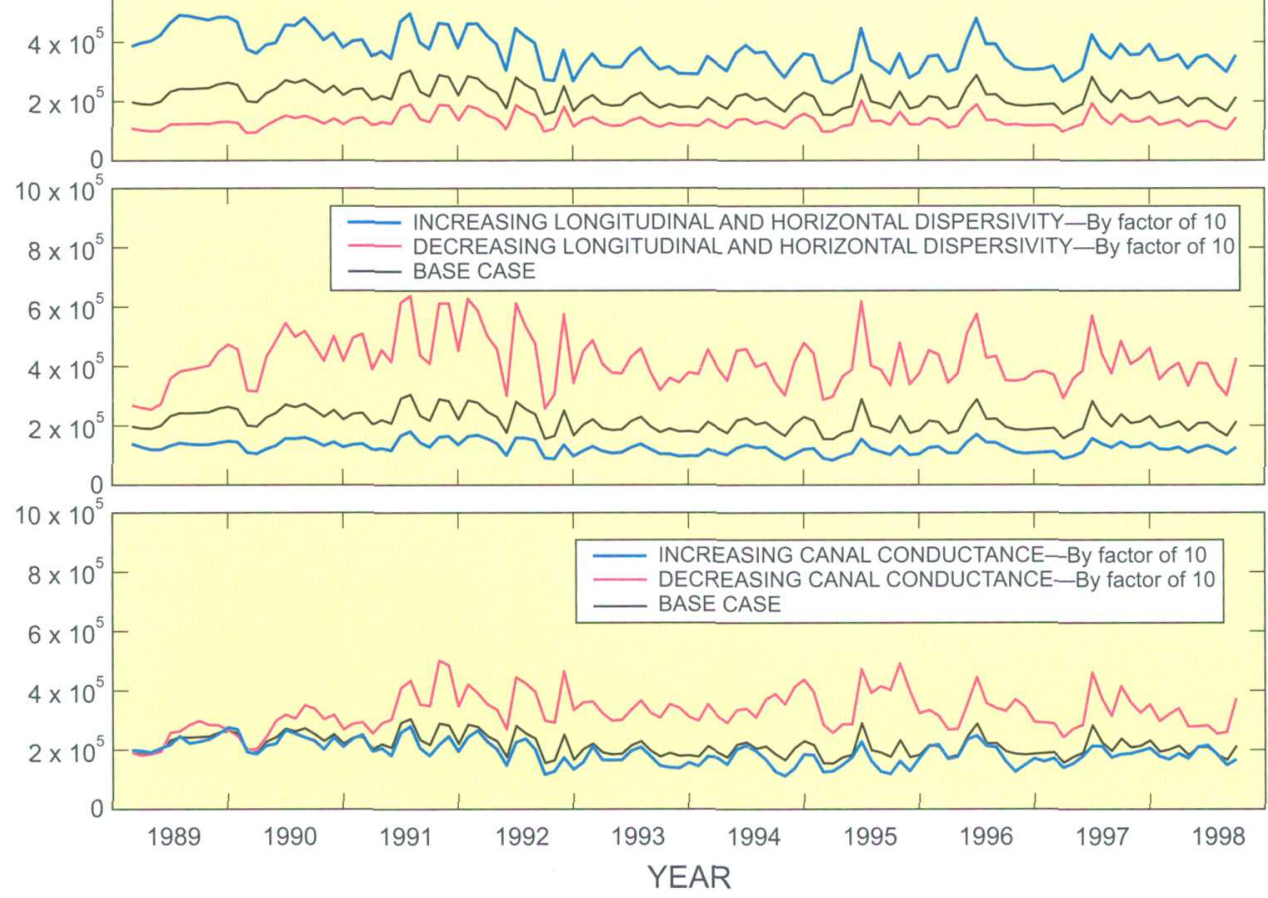

Figure 34. Sensitivity analysis of regional-scale model depicting range of simulated fresh ground-water discharge to Biscayne Bay. 
Two sensitivity runs were performed to evaluate the effect of canal conductance on fresh ground-water discharge to Biscayne Bay. An increase in river conductance by a factor of 10 does not greatly affect the simulated discharge rates (fig. 34), but a decrease in canal conductance does affect the simulated groundwater discharge rates (fig. 34). A decrease in canal conductance increases the freshwater discharge to Biscayne Bay probably because ground water that is intercepted by canals in the base case is allowed to discharge to the bay in the sensitivity run.

\section{Model Limitations}

Numerical models of ground-water flow are limited in their representation of the physical system because they contain simplifications and assumptions that may or may not be valid. Results from groundwater flow models have a degree of uncertainty primarily because detailed three-dimensional distributions of aquifer parameters are rarely, if ever, available. Results from solute-transport models have more uncertainty because they depend on ground-water velocities calculated from flow models and other uncertain parameters specific to solute transport. Variable-density, ground-water models have even more uncertainty and error associated with them because ground-water velocities are affected by solute concentrations. Results from variable-density models must be evaluated with caution because of uncertainties and potential errors inherent in these types of models. The cross-sectional and regional-scale models developed for this study clearly have uncertainty and error. Limitations in the numerical models that may cause errors in the results can be divided into two categories:

(1) invalid assumptions or approach implemented by the numerical simulation code, and (2) inaccurate conceptual model, aquifer parameters, boundary conditions, or initial conditions.

SEAWAT is a relatively new code that has not been widely used by ground-water modelers. However, the code has been verified with a number of benchmark problems, and the results compare well with results from other codes and analytical solutions. Inherent in the SEAWAT code are a number of assumptions that may limit the reliability of the numerical models developed for this study. The most limiting assumption is that of an equivalent porous medium. Numerous investigators have documented the presence of preferential pathways in the Biscayne aquifer. These pathways may provide the mechanisms for transporting fresh ground water to offshore springs in Biscayne Bay. The SEAWAT code and finitedifference codes in general are not designed to simulate conduit flow. Instead, the effects of conduits are indirectly incorporated into the model by increasing the bulk hydraulic conductivity. At large scales, this approach is probably valid for simulating flow volumes, but may not accurately represent the transport processes. For these reasons, results from the crosssectional models are limited if conduits affect groundwater flow at the Coconut Grove and Deering Estate transects. Results from the regional-scale model may be limited as well. The accurate simulation of flow volumes in variable-density, ground-water systems depends on the accurate simulation of the transport processes. Although the regional-scale model seems to reasonably represent the flow and transport processes, there is a level of inherent error in the model that cannot be quantified without a more thorough study of conduit flow in the Biscayne aquifer.

Of the many assumptions used by the MODFLOW and MT3D codes, and hence the SEAWAT code, several are worth discussion. The explicit coupling method in the SEAWAT code uses a one timestep lag between solutions to the flow and transport equations. An evaluation of this approach indicates that a one timestep lag does not introduce large errors, but the potential for error does exist. The assumption of isothermal conditions may also limit the results of the models developed for this study. Thermal gradients can affect fluid density, and thus, ground-water flow patterns. Thermal gradients have been observed in the Biscayne aquifer, but these thermal gradients seem to have little effect on ground-water flow. SEAWAT does not account for variations in viscosity. Previous studies suggest that viscosity variations are not important unless fluid densities exceed $1,200 \mathrm{~kg} / \mathrm{m}^{3}$. For this study, fluid densities do not exceed $1,025 \mathrm{~kg} / \mathrm{m}^{3}$, suggesting that variations in fluid viscosity probably do not affect ground-water flow.

Inaccuracies in the model simulations are probably the result of inaccurate conceptual models or errors in aquifer parameters, boundary conditions, and/or initial conditions. Based on the complex nature of variable-density ground-water systems, the crosssectional models were calibrated with an assumption of steady state. Kohout and Klein (1967) report that the transition zone can respond to recharge events. However, chloride concentrations measured at the 
Coconut Grove, Deering Estate, and Mowry Canal transects, however, did not show substantial fluctuations, which may suggest that an assumption of steady state may be valid at least for the short duration when chlorides were monitored. A more significant problem with the cross-sectional models is that simulated concentrations beneath Biscayne Bay are too high. Results from recent simulations suggest that this problem could be resolved by using the specified concentration for inflow as the solute-transport boundary type for Biscayne Bay. Inaccurate aquifer parameters in the model could also result in simulated concentrations that are too high beneath the bay. Kwiatkowski (1987) used a heterogeneous distribution of hydraulic conductivity in his variable-density, cross-sectional model of Deering Estate to better match the distribution of observed heads. Observed heads suggest that there may be a vertical section of higher hydraulic conductivity between two vertical sections of lower hydraulic conductivity (Kwiatkowski, 1987). This distribution for hydraulic conductivity was tested in the present study; although it was possible to better simulate the observed heads, the simulated concentrations of salinity did not match observed concentrations. It is likely that a heterogeneous distribution of aquifer parameters is controlling ground-water flow patterns at Deering Estate, making it difficult to calibrate with the available data. The results from the Deering Estate model, therefore, contain some error, but as a general representation of coastal ground-water flow, the model results probably are reasonable.

In the development of a ground-water model for southern Miami-Dade County, Merritt (1996a) calibrated aquifer parameters and boundary conditions by matching observed fluctuations in head and canal flow. Based on Merritt's (1996a) accurate simulation of head fluctuations and canal flow, the calibrated aquifer parameters and boundary conditions seem to be reasonable approximations of the physical system, although they probably contain some level of error. The distribution of hydraulic conductivity and the storage value derived by Merritt (1996a) were used in the regional-scale model for the area south of the Tamiami Canal (Merritt's model domain) and the area north of the Tamiami Canal (outside of Merritt's model domain). The aquifer parameters used in the regionalscale model, therefore, probably contain some error. However, based on the capability of the regional-scale model to simulate fluctuations in head, canal baseflow, and the general position of the saltwater interface, the model seems to be a reasonable representation of the physical system.

The processes of rainfall, runoff, recharge, and evapotranspiration were difficult to represent in the regional-scale model because of their complex interrelations. Simplifications were used to represent these processes in the model, adding uncertainty to the reliability of model results. For example, the model does not simulate evapotranspiration from the unsaturated zone, which may be an important process along the Atlantic Coastal Ridge (fig. 2) where the unsaturated zone is relatively thick. The quantity of unsaturated zone evapotranspiration probably is indirectly included in one of the other model processes, such as runoff, baseflow to canals, or evapotranspiration from the water table.

Horizontal and vertical discretization in the regional-scale model also introduces error in model results. Because the model cells are 1,000 by 1,000 by $5 \mathrm{~m}$, the effects of canals and well fields are averaged over large volumes. This averaging will cause results from the regional-scale model to be imprecise at smaller scales. Additionally, the large model cells probably cause a certain level of numerical dispersion, which may limit the capability of the model to accurately simulate the position and characteristics of the freshwater-saltwater transition zone. Numerical dispersion in the model, therefore, could affect the simulated ground-water discharge values to Biscayne Bay.

Results from the regional-scale model suggest that fresh ground-water discharge to Biscayne Bay is a small component of the total freshwater discharge to the bay. Although this conclusion is important, it indicates that there is a large degree of uncertainty in the simulated discharge values. Small errors in the other water-budget components can substantially affect the simulated ground-water discharge rates. It appears that simulated values of fresh ground-water discharge are within the error tolerance of the model. However, the spatial trends, which show most of the fresh groundwater discharge to tidal canals and the northern half of Biscayne Bay, probably are reasonable.

\section{CONCLUSIONS}

Based on the research documented in this report, general conclusions about the discharge of ground water to Biscayne Bay are as follows:

- Based on the results from a regional-scale, variabledensity, ground-water flow model, the average 
rate of fresh ground-water discharge to Biscayne Bay seems to be about 6 percent of the average rate of surface-water discharge to the bay. During dry periods, however, monthly average rates of fresh ground-water discharge can exceed surfacewater discharge, which suggests that groundwater discharge to Biscayne Bay may be dominant during certain times.

- Temporal variations in average monthly groundwater discharge are caused by relatively large variations in sea-level elevation as well as seasonal variations in the height of the water table.

- Fresh ground-water discharge to Biscayne Bay is spatially variable. Fresh ground-water discharge to the tidal portions of the Miami and Coral Gables Canals probably is similar in magnitude to the coastal ground-water discharge to Biscayne Bay. Nearly all of the fresh ground-water discharge directly to Biscayne Bay occurs north of structure S-123. Ground-water discharge rates south of this structure are minimal because lowlying areas adjacent to the bay suppress the elevation of the water table and reduce the hydraulic gradient toward the coast.

- The field data and results from the numerical models suggest that ground-water discharge to Biscayne Bay is confined to a narrow band adjacent to the coast that probably is less than $1 \mathrm{~km}$ wide. The ground-water discharge band is probably about $1 \mathrm{~km}$ wide near the Deering Estate. North of the Deering Estate, the discharge band is probably hundreds of meters wide; whereas south of the Deering Estate, it is probably only tens of meters wide, if present at all. The concept of a narrow discharge band is most meaningful in a regional context because it is based on field data at three discrete transects and the results from numerical models that are based on the assumption of an equivalent porous medium. Therefore, at local-scales where preferential ground-water flow pathways or conduits may be present, the concept of the narrow discharge band may not apply.

Results from this study have a large degree of uncertainty, which is why conclusions are reported in relative terms rather than absolute values. The large degree of uncertainty is primarily attributed to two reasons: (1) ground-water discharge rates were not directly measured, and (2) ground-water discharge rates were indirectly estimated with a variable-density ground-water flow model. Attempts to use seepage meters to directly measure discharge rates were unsuccessful. Future attempts to measure ground-water discharge to Biscayne Bay would probably benefit from trying to incorporate some direct measurement technique of discharge as well as measurements of salinity in the bay. Variable-density models require the accurate simulation of transport processes and the accurate simulation of flow processes. Errors in this type of model are compounded because flow and transport are coupled processes. Although these uncertainties limit the reliability of the simulated discharge estimates, the estimates probably are the best available because they were derived with a physics-based ground-water flow model that includes the variabledensity effects known to influence coastal groundwater flow.

\section{REFERENCES CITED}

Anderson, M.P., and Woessner, W.W., 1992, Applied groundwater modeling, simulation of flow and advective transport: San Diego, Calif., Academic Press, Inc., $381 \mathrm{p}$.

Anderson, P.F., Mercer, J.W., and White, H.O., 1988, Numerical modeling of salt-water intrusion at Hallandale, Florida: Ground Water, v. 26, no. 5, p. 619-633.

Brown, Eugene, Skougstad, M.W., Fishman, M.J., 1974, Methods for collection and analysis of water samples for dissolved minerals and gases: U.S. Geological Survey Techniques of Water Resource Investigation: book 5, chap. A1, 160 p.

Brown, R.H., and Parker, G.G., 1945, Salt water encroachment in limestone at Silver Bluff, Miami, Florida: Economic Geology, v. 60, no. 4, p. 235-262.

Byrne, M.J., 1999, Groundwater nutrient loading in Biscayne Bay, Biscayne National Park, Florida: Miami, Florida International University, M.S. thesis, $88 \mathrm{p}$.

Cooper, H.H., 1959, A hypothesis concerning the dynamic balance of fresh water and salt water in a coastal aquifer: Journal of Geophysical Research, v. 64, no. 4, p. 461-467.

Cooper, H.H., Kohout, F.A., Henry, H.R., and Glover, R.E., 1964, Sea water in coastal aquifers, U.S. Geological Survey Water-Supply Paper 1613-C, 84 p.

Cooper, R.P., and Lane, James, 1987, An atlas of eastern Dade County surface water management basins: South Florida Water Management District Technical Memorandum, $97 \mathrm{p}$.

Domenico, P.A., and Schwartz, F.W., 1990, Physical and chemical hydrology: New York, NY, John Wiley and Sons, Inc., 824 p. 
Elder, J.W., 1967, Transient convection in a porous medium: Journal of Fluid Mechanics, v. 27, no. 3, p. 609-623.

Fetter, C.W., 1993, Contaminant Hydrogeology: New York, N.Y., Macmillan Publishing Company, 458 p.

Fish, J.E., 1988, Hydrogeology, aquifer characteristics, and ground-water flow of the surficial aquifer system, Broward County, Florida: U.S. Geological Survey Water-Resources Investigations Report 87-4034, 92 p.

Fish, J.E., and Stewart, M.T., 1991, Hydrogeology of the surficial aquifer system, Dade County, Florida: U.S. Geological Survey Water-Resources Investigations Report 90-4108, 50 p.

Fitterman, D.V., and Deszcz-Pan, M., 1998, Helicopter EM mapping of saltwater intrusion in Everglades National Park: Florida Exploration Geophysics, v. 29, p. 240243.

Fitterman, D.V., Deszcz-Pan, M., and Stoddard, C.E., 1999, Results of time-domain electromagnetic soundings in Everglades National Park, Florida: U.S. Geological Survey Open-File Report 99-426, 1 CD-ROM.

Gelhar, L.W., 1986, Stochastic subsurface hydrology, from theory to applications: Water Resources Research, v. 22 , no. 9 , p. $135 \mathrm{~S}-145 \mathrm{~S}$

Guo, Weixing, and Bennett, G.D., 1998, Simulation of saline/fresh water flows using MODFLOW, in Poeter, E., and others, MODFLOW '98 Conference, Golden, Colorado, 1998, Proceedings: Golden, Colorado, v. 1, p. 267-274.

Henry, H.R., 1964, Effects of dispersion on salt encroachment in coastal aquifers: U.S. Geological Survey Water-Supply Paper 1613-C, p. C71-C84.

Hittle, C.D., 1999, Delineation of saltwater intrusion in the surficial aquifer system in eastern Palm Beach, Martin, and St. Lucie Counties, Florida, 1997-98: U.S. Geological Survey Water-Resources Investigations Report 994214, 1 sheet.

Hogg, R.W., 1991, Numerical simulation of saltwater intrusion, Biscayne aquifer, Cutler Ridge, Florida; Comparison of SUTRA and MOCDENS: Tampa, University of South Florida, M.S. thesis, 103 p.

Hull, J.E., and Meyer, F.W., 1973, Salinity studies in East Glades agricultural area, southeastern Dade County, Florida: Florida Bureau of Geology Report of Investigation, No. 66, 39 p.

Interpex Limited, 1996, Temix XL V4: Transient electromagnetic data interpretation software: User's Manual, $382 \mathrm{p}$.

Kipp, K.L., 1997, Guide to the revised heat and solute transport simulator: HST3D-Version 2, U.S.Geological Survey Water-Resources Investigation Report 97 4157, 149 p.

Klein, Howard, 1957, Salt-water encroachment in Dade County, Florida: Florida Geological Survey Information Circular 9, 5 p.
Klein, Howard, and Waller, B.G., 1985, Synopsis of saltwater intrusion in Dade County, Florida, through 1984: U.S. Geological Survey Water-Resources Investigations Report 85-4101, 1 sheet.

Klein, Howard, and Ratzlaff, K.W., 1989, Changes in saltwater intrusion in the Biscayne aquifer, Hialeah-Miami Springs area, Dade County, Florida: U.S. Geological Survey Water-Resources Investigations Report 874249, 1 sheet.

Kohout, F.A., 1960a, Cyclic flow of saltwater in the Biscayne aquifer of southeastern Florida: Journal of Geophysical Research, v. 65, no. 7, p. 2133-2141.

,$- 1960 \mathrm{~b}$, Flow pattern of fresh water and salt water in the Biscayne aquifer of the Miami area, Florida: International Association of Scientific Hydrology, Commission of Subterranean Waters, p. 440-448.

,- 1961 a, Fluctuations of ground-water levels caused by dispersion of salts: Journal of Geophysical Research, v. 66, no. 8, p. 2429-2434.

$\longrightarrow, 1961 \mathrm{~b}$, Case history of salt water encroachment caused by a storm sewer in Miami: Journal of the American Water Works Association, v. 53, no. 11, p. 1406-1416.

- 1964, The flow of fresh water and salt water in the Biscayne aquifer of the Miami area, Florida; in Sea Water in Coastal Aquifers: U.S. Geological Survey Water-Supply Paper 1613-C, p. 12-32.

Kohout, F.A., and Hoy, N.D., 1963, Some aspects of sampling salty ground water in coastal aquifers: Ground Water, v. 1 , no. 1, p 28-32.

Kohout, F.A., and Klein, Howard, 1967, Effect of pulse recharge on the zone of diffusion in the Biscayne aquifer: International Association of Scientific Hydrology, Publication no. 70, p. 252-270.

Kohout, F.A., and Kolipinski, M.C., 1967, Biological zonation related to groundwater discharge along the shore of Biscayne Bay, Miami, Florida: Estuaries, no. 83, p. 488-499.

Konikow, L.F., and Reilly, T.E., 1999, Seawater intrusion in the United States; in J. Bear and others, eds., Seawater intrusion in coastal aquifers-concepts, methods and practices: AA Dordrecht, The Netherlands, Kluwer Academic Publishers, $625 \mathrm{p}$.

Konikow, L.F., Sanford, W.E., and Campbell, P.J., 1997, Constant-concentration boundary condition; lessons from the HYDROCOIN variable-density groundwater benchmark problem: Water Resources Research, v. 33, no. 10 , p. 2253-2261.

Kwiatkowski, P.J., 1987, Numerical simulation of seawater intrusion, Cutler Ridge, Florida: Tampa, University of South Florida, M.S. thesis, 85 p.

Langevin, C.D., and Guo, Weixing, 1999, Improvements to SEAWAT, a variable-density modeling code [abs.] in Eos, Transactions, v. 80, no. 46., P. F-373. 
Leake, S.A., and Claar, D.V., 1999, Procedures and computer programs for telescopic mesh refinement using MODFLOW: U.S. Geological Survey Open-File Report 99-238, 53p.

Lee, C.H., and Cheng R.T., 1974, On seawater encroachment in coastal aquifers: Water Resources Research, v. 10 , no. 5 , p. 1039-1043.

Lusczynski, N.J., 1961, Head and flow of ground water of variable density: Journal of Geophysical Research, v. 66 , no. 12 , p. $4247-4256$.

McDonald, M.G., and Harbaugh, A.W., 1988, A modular three-dimensional finite-difference ground-water flow model: U.S.Geological Survey Techniques of Water Resources Investigations, Book 6, 586 p.

Merritt, M.L., 1996a, Simulation of the water table altitude in the Biscayne aquifer, southern Dade County, Florida, water years 1945-89: U.S Geological Survey Water-Supply Paper 2458, 148 p. , 1996b, Numerical simulation of a plume of brackish water in the Biscayne aquifer originating from a flowing artesian well, Dade County, Florida: U.S. Geological Survey Water- Supply Paper 2464, 74 p.

Oude Essink, G.H.P. and Boekelman, R.H., 1996, Problems with large-scale modeling of salt water intrusion in 3D, 14th Salt Water Intrusion Meeting, Malmo, Sweden, 1996, Proceedings: Malmo, Sweden p. 288-299.

Parker, G.G., 1945, Salt water encroachment in southern Florida: Journal of the American Water Works Association, v. 37 , no. 6 , p. 526-542.

- 1951, Geologic and hydrologic factors in the perennial yield of the Biscayne aquifer, Miami area, Florida: Journal American Water Works Association, v. 43 , no. 10 , p. $817-835$.

Parker, G.G., Ferguson, G.E., Love, S.K., and others, 1955, Water resources of southeastern Florida: Geological Survey Water-Supply Paper 1255, 965 p.

Reese, R.S., and Cunningham, K.J., 2000, Hydrogeology of the Gray Limestone Aquifer in Southern Florida: U.S. Geological Survey Water-Resources Investigations Report 99-4213, 244 p.

Restrepo, J.I., Bevier, Cindy, and Butler, David, 1992, A Three-Dimensional Finite Difference Ground Water Flow Model of the Surficial Aquifer System, Broward County, Florida: South Florida Water Management District Technical Publication DRE-314, 261 p.

Segol, Genevieve, and Pinder, G.F., 1976, Transient simulation of salt water intrusion in south eastern Florida: Water Resources Research, v. 12, p. 65-70.
Segol, Genevieve, 1993, Classic groundwater simulations: Proving and improving numerical models: Prentice Hall, $531 \mathrm{p}$.

Shinn, E.A., Reese, R.S., and Reich, C.D., 1994, Fate and pathways of injection-well effluent in the Florida Keys: U.S. Geological Survey Open-File Report 94276, $116 \mathrm{p}$.

Shoemaker, W.B., 1998, Geophysical delineation of hydrostratigraphy within the Big Cypress National Preserve: Tampa, University of South Florida, M.S. thesis, 91 p.

Simmons, C.T., Narayan, K.A., and Wooding, R.A., 1999, On a test case for density-dependent groundwater flow and solute transport models: The salt lake problem: Water Resources Research, v. 35, no. 12, p. 3607-3620.

Sonenshein, R.S., 1997, Delineation and extent of saltwater intrusion in the Biscayne aquifer, Eastern Dade County, Florida, 1995: U.S. Geological Survey WaterResources Investigations Report 96-4285, 1 sheet.

Sonenshein, R.S., and Koszalka, E.J., 1996, Trends in water-table altitude (1984-93) and saltwater intrusion (1974-93) in the Biscayne aquifer, Dade County, Florida: U.S. Geological Survey Open-File Report 95-705, 2 sheets.

Swain, E.D., Howie, Barbara, and Dixon, Joann, 1996, Description and field analysis of a coupled groundwater/surface-water flow model (MODFLOW/ BRANCH) with modifications for structures and wetlands in southern Dade County, Florida: U.S. Geological Survey Water-Resources Investigations Report 96-4118, 67 p.

Taniguchi, Makoto, Cable, J.E., and Burnett, W.C., 1999, Compilation of worldwide submarine groundwater discharge estimates [abs.]; in AGU 1999 fall meeting: Supplement to Eos, Transactions, v. 80, no. 46, 1251 p.

Voss, C.I., 1984, SUTRA: A finite-element simulation model for saturated-unsaturated, fluid-densitydependent ground-water flow with energy transport or chemically reactive single-species solute transport: U.S. Geological Survey Water-Resources Investigation Report 84-4369, 409 p.

Voss, C.I., and Souza, W.R., 1987, Variable density flow and solute transport simulation of regional aquifers containing a narrow freshwater-saltwater transition zone: Water Resources Research, v. 23, no. 10, p. 1851-1866.

Zheng, Chunmiao, 1990, MT3D: A modular three-dimensional transport model for simulation of advection, dispersion and chemical reactions of contaminants in groundwater systems: Report to the U.S. Environmental Protection Agency, Ada, OK, 170 p. 


\section{APPENDIXES}




\section{Appendix I \\ Lithologic Descriptions of Selected Cores as Determined for this Study}

[Abbreviations: FGS, Florida Geological Survey; USGS, U.S. Geological Survey]

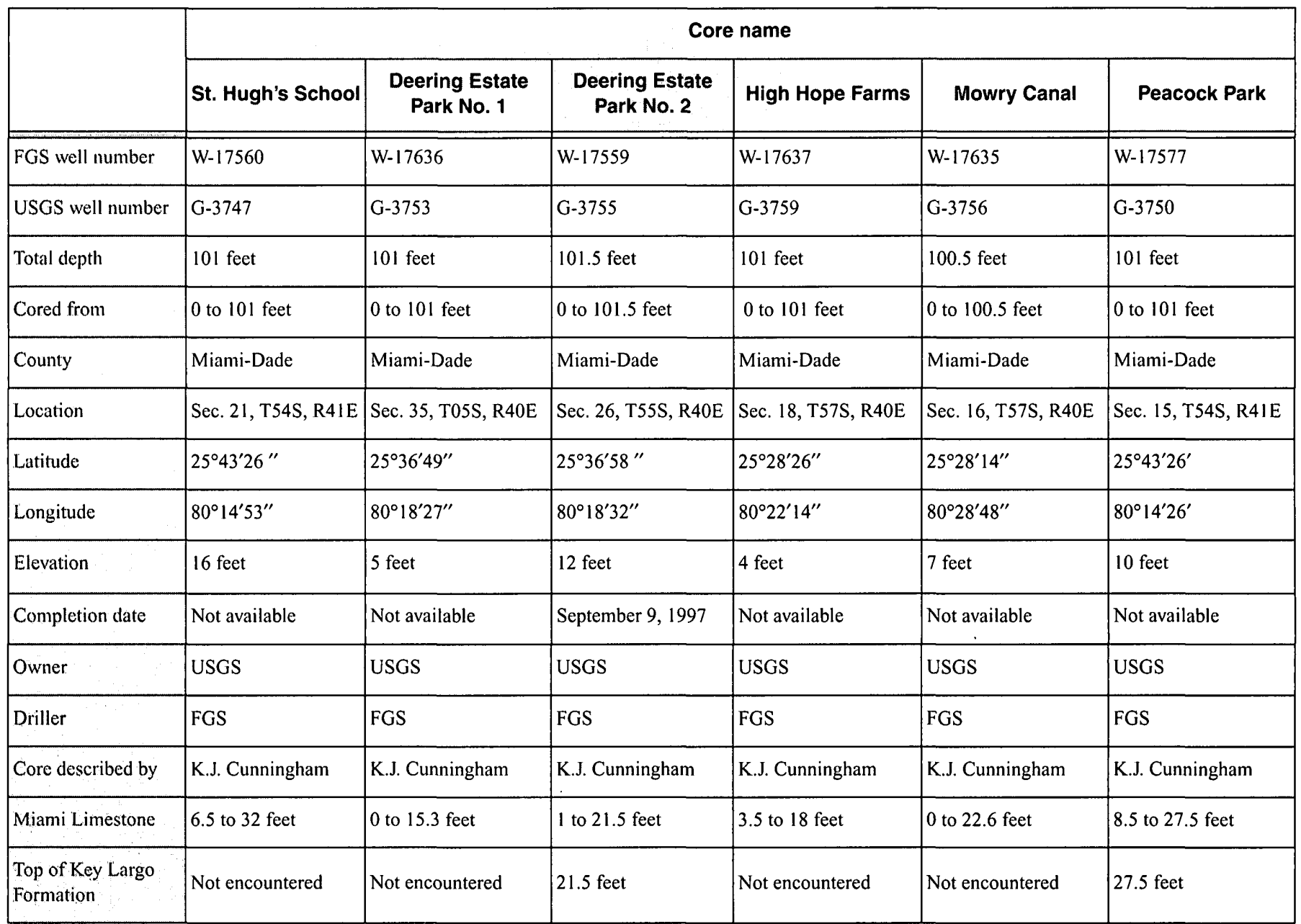




\section{St. Hugh's School Core}

\begin{tabular}{|c|c|}
\hline $\begin{array}{l}\text { Depth } \\
\text { (feet below } \\
\text { land } \\
\text { surface) }\end{array}$ & Lithologic description \\
\hline $0.0-2.0$ & $\begin{array}{l}\text { Asphalt, loose quartz sand and Holocene roots, medium-dark-gray N4 to black N1; mainly silt to medium grain size, ranges } \\
\text { from silt to coarse; } 90 \text { percent fine to coarse quartz sand; } 5 \text { to } 20 \text { percent interparticle porosity; very low to moderate hydrau- } \\
\text { lic conductivity. }\end{array}$ \\
\hline $2.0-4.0$ & $\begin{array}{l}\text { Loose quartz sand, grayish-orange } 10 \mathrm{YR} 7 / 4 \text {; mainly silt to medium grain size, ranges from silt to medium; } 95 \text { percent fine } \\
\text { to medium quartz sand; } 25 \text { percent interparticle porosity; high hydraulic conductivity; iron-oxide coating on quartz grains. }\end{array}$ \\
\hline $4.0-5.0$ & $\begin{array}{l}\text { Loose quartz sand with clasts of limestone; medium-light-gray N6; mainly silt to fine grain size, ranges from clay to } \\
\text { medium; } 95 \text { percent fine to medium quartz sand, } 5 \text { percent limestone clasts; } 20 \text { percent interparticle porosity; high hydraulic } \\
\text { conductivity. }\end{array}$ \\
\hline $5.0-6.0$ & $\begin{array}{l}\text { Friable quartz sand, dark-yellowish-orange } 10 \mathrm{YR} 6 / 6 \text {; mainly fine to medium grain size; ranges from fine to medium; } 95 \\
\text { percent quartz sand; iron-oxide coating on quartz grains; } 20 \text { percent interparticle porosity; moderate hydraulic conductivity. }\end{array}$ \\
\hline $6.0-6.5$ & $\begin{array}{l}\text { Friable quartz sand; dark-yellowish-brown } 10 \text { YR } 6 / 6 \text { and very pale orange } 10 \mathrm{YR} 8 / 2 ; \text { mainly clay to fine-grained quartz, } \\
\text { ranges from clay to medium; } 80 \text { percent fine to medium quartz sand, } 10 \text { percent clay, } 10 \text { percent clasts of oolitic lime grain- } \\
\text { stone; } 5 \text { percent interparticle porosity; low hydraulic conductivity. }\end{array}$ \\
\hline $6.5-7.5$ & $\begin{array}{l}\text { Highly burrowed oolitic lime grainstone; very pale orange } 10 \mathrm{YR} 8 / 2 \text {; mainly medium grain size, ranges from medium to } \\
\text { pebble; mollusks; } 20 \text { percent interparticle and vuggy porosity; high hydraulic conductivity. }\end{array}$ \\
\hline $7.5-12.5$ & $\begin{array}{l}\text { Highly burrowed oolitic lime grainstone, very pale orange } 10 \mathrm{YR} 8 / 2 \text {; mainly medium grain size, ranges from medium to } \\
\text { pebble; skeletal fragments and mollusks; } 30 \text { percent oomoldic, interparticle, vuggy and solution-channel porosity; very high } \\
\text { hydraulic conductivity. }\end{array}$ \\
\hline $12.5-13.5$ & $\begin{array}{l}\text { Rubble of highly burrowed oolitic lime grainstone, very pale orange } 10 \mathrm{YR} 8 / 2 \text {; mainly medium grain size, ranges from } \\
\text { medium to pebble; skeletal fragments and mollusks; } 30 \text { percent oomoldic, interparticle, vuggy and solution-channel poros- } \\
\text { ity; very high hydraulic conductivity. }\end{array}$ \\
\hline $13.5-16.0$ & No recovery \\
\hline $16.0-19.0$ & $\begin{array}{l}\text { Highly burrowed oolitic lime grainstone with minor oolitic packstone, very pale orange } 10 \mathrm{YR} 8 / 2 \text {; mainly medium grain } \\
\text { size, ranges from clay to pebble; mollusks and bryozoans; } 30 \text { percent oomoldic, vuggy and interparticle porosity; very high } \\
\text { hydraulic conductivity. }\end{array}$ \\
\hline $19.0-21.0$ & No recovery \\
\hline $21.0-23.0$ & $\begin{array}{l}\text { Burrowed oolitic lime grainstone, very pale orange } 10 \text { YR } 8 / 2 \text {; mainly medium grain size, ranges from fine to pebble; } 10 \text { per- } \\
\text { cent fine- to medium-grained quartz sand, mollusks; } 20 \text { percent oomoldic, vuggy and interparticle porosity; high hydraulic } \\
\text { conductivity. }\end{array}$ \\
\hline $23.0-26.0$ & S. \\
\hline $26.0-27.0$ & $\begin{array}{l}\text { Rubble of oolitic lime grainstone, very pale orange } 10 \text { YR } 8 / 2 \text {; mainly medium grain size, ranges from fine to pebble; } 15 \text { per- } \\
\text { cent fine- to medium-grained quartz sand, mollusks; } 25 \text { percent oomoldic, interparticle and vuggy porosity; high hydraulic } \\
\text { conductivity. }\end{array}$ \\
\hline $27.0-31.7$ & No recovery \\
\hline $31.7-32.0$ & $\begin{array}{l}\text { Rubble of oolitic lime grainstone, very pale orange } 10 \mathrm{YR} 8 / 2 ; \text { mainly medium grain size, ranges from fine to pebble; } 15 \text { per- } \\
\text { cent fine- to medium-grained quartz sand, skeletal fragments; } 25 \text { percent oomoldic, interparticle and vuggy porosity; high } \\
\text { hydraulic conductivity. }\end{array}$ \\
\hline $32.0-33.0$ & $\begin{array}{l}\text { Mollusk fragment lime floatstone with quartz sand-ricb lime packstone matrix, mottled dark-yellowish-orange } 10 \mathrm{YR} 6 / 6 \text {, } \\
\text { grayish-orange } 10 \mathrm{YR} 714 \text {, pale-yellowish-brown } 10 \mathrm{YR} 6 / 2 \text { to very pale orange } 10 \mathrm{YR} 8 / 2 \text {; mainly clay and fine to medium } \\
\text { grain size, ranges from clay to pebble; } 20 \text { percent fine- to medium-grained quartz sand, skeletal fragnents and mollusks; } \\
\text { abundant root molds, subaerial exposure zone; } 25 \text { percent interparticle, vuggy, root-mold and solution-channel porosity; } \\
\text { very high hydraulic conductivity. }\end{array}$ \\
\hline $33.0-35.0$ & $\begin{array}{l}\text { Monastrea lime framestone, very pale orange } 10 \mathrm{YR} 8 / 2 \text {; mainly cobble to boulder grain size, ranges from cobble to boulder; } \\
30 \text { percent intraparticle porosity; very high hydraulic conductivity. }\end{array}$ \\
\hline $35.0-41.0$ & 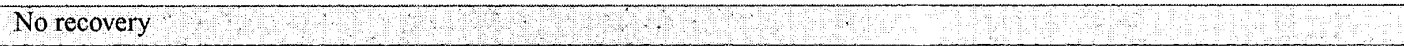 \\
\hline $41.0-44.0$ & $\begin{array}{l}\text { Monastrea lime framestone, very pale orange } 10 \mathrm{YR} 8 / 2 \text {; mainly cobble to boulder grain size, ranges from cobble to boulder; } \\
30 \text { percent intraparticle porosity; very high hydraulic conductivity. }\end{array}$ \\
\hline $44.0-46.0$ & $\begin{array}{l}\text { Skeletal-fragment lime floatstone with peloid lime packstone matrix, very pale orange } 10 \mathrm{YR} 8 / 2 \text {, mainly clay, silt and peb- } \\
\text { ble grain size, ranges from clay to pebble; mollusks and coral fragments; } 30 \text { percent vuggy and solution-channel porosity; } \\
\text { very high hydraulic conductivity; very "rotten" vuggy texture, possible exposure surface at } 44 \text { feet. }\end{array}$ \\
\hline
\end{tabular}




\begin{tabular}{|c|c|}
\hline $\begin{array}{l}\text { Depth } \\
\text { (feet below } \\
\text { land } \\
\text { surface) }\end{array}$ & Lithologic description \\
\hline $48.0-48.5$ & $\begin{array}{l}\text { Skeletal-fragment lime grainstone, very pale orange } 10 \mathrm{YR} 8 / 2 \text {; mainly very fine to granule grain size, ranges from very fine } \\
\text { to pebble; mollusks, gastropods and benthic foraminifers; } 30 \text { percent moldic and vuggy porosity; very high hydraulic con- } \\
\text { ductivity; very "rotten" vuggy texture. }\end{array}$ \\
\hline $48.5-49.0$ & $\begin{array}{l}\text { Skeletal-fragment-rich quartz sandstone; very pale orange } 10 \mathrm{YR} 8 / 2 \text {; mainly very fine to fine grain size, ranges from very } \\
\text { fine to granule; } 40 \text { percent very fine to fine quartz sand; } 25 \text { percent vuggy and interparticle porosity; high hydraulic conduc- } \\
\text { tivity. }\end{array}$ \\
\hline $49.0-50.0$ & $\begin{array}{l}\text { Skeletal fragment lime floatstone with matrix of skeletal fragment quartz sand-rich lime packstone, very pale orange } 10 \mathrm{YR} \\
8 / 2 ; \text { mainly very fine to fine and pebble grain size, ranges from very fine to pebble; } 40 \text { percent very fine to fine quartz sand; } \\
\text { mollusks, gastropods and sand dollars; } 25 \text { percent vuggy and interparticle porosity; high hydraulic conductivity. }\end{array}$ \\
\hline $50.0-55.0$ & No recovery. \\
\hline $55.0-55.5$ & $\begin{array}{l}\text { Rubble of skeletal-fragment lime floatstone with quartz sand-rich lime grainstone matrix, very pale orange } 10 \mathrm{YR} 8 / 2 \text {; } \\
\text { mainly very fine to pebble grain size, ranges from very fine to pebble; } 20 \text { percent very fine quartz sand; } 30 \text { percent vuggy } \\
\text { and interparticle porosity; high hydraulic conductivity; root molds, very "rotten" vuggy texture. }\end{array}$ \\
\hline $55.5-56.3$ & $\begin{array}{l}\text { Moldic skeletal fragment lime floatstone with matrix of skeletal fragment lime packstone; very pale orange } 10 \mathrm{YR} 8 / 2 ; \\
\text { mainly clay to pebble grain size, ranges from clay to pebble; mollusks; } 30 \text { percent moldic and solution-channel porosity; } \\
\text { very high hydraulic conductivity. }\end{array}$ \\
\hline $56.3-58.7$ & $\begin{array}{l}\text { Moldic skeletal fragment lime floatstone with matrix of skeletal fragment lime wackestone; very pale orange } 10 \mathrm{YR} 8 / 2 \text { to } \\
\text { grayish orange } 10 \mathrm{YR} 7 / 4 \text {; mainly clay to medium grain size, ranges from clay to pebble; mollusks and sponges(?); } 30 \text { per- } \\
\text { cent moldic and solution-channel porosity; very high hydraulic conductivity. }\end{array}$ \\
\hline $58.7-61.0$ & No recovery. \\
\hline $61.0-62.5$ & $\begin{array}{l}\text { Rubble of skeletal-fragment lime packstone, very pale orange l0YR } 8 / 2 \text {; mainly clay to medium grain size, ranges from clay } \\
\text { to pebble; } 5 \text { percent very fine to medium quartz sand, mollusks and miliolids; vuggy, moldic and solution-channel porosity; } \\
\text { high hydraulic conductivity; root molds. }\end{array}$ \\
\hline $62.5-68.0$ & No recovery. \\
\hline $68.0-69.5$ & $\begin{array}{l}\text { Rubble of skeletal, quartz-sand-rich lime packstone and grainstone, very pale orange } 10 \mathrm{YR} 8 / 2 \text {; mainly clay to granule grain } \\
\text { size, ranges from clay to pebble; } 20 \text { to } 40 \text { percent very fine to fine quartz sand, miliolids and mollusks; } 25 \text { percent vuggy and } \\
\text { moldic porosity; high hydraulic conductivity; root molds. }\end{array}$ \\
\hline $69.5-75.0$ & No recovery. \\
\hline $75.0-75.5$ & $\begin{array}{l}\text { Rubble of skeletal fragment, quartz sand-rich lime packstone and wackestone; very pale orange } 10 \mathrm{YR} 8 / 2 \text {; mainly very fine } \\
\text { to fine grain size, ranges from clay to coarse; } 30 \text { percent fine quartz sand; } 25 \text { percent moldic and vuggy porosity; high } \\
\text { hydraulic conductivity; solution channels filled with very fine to fine quartz sand. }\end{array}$ \\
\hline $75.5-77.4$ & $\begin{array}{l}\text { Monastrea lime framestone, very pale orange } 10 \mathrm{YR} 8 / 2 \text {; mainly cobble to boulder grain size, ranges from cobble to boulder; } \\
25 \text { percent moldic and vuggy porosity; very high hydraulic conductivity. }\end{array}$ \\
\hline $77.4-78.3$ & $\begin{array}{l}\text { Skeletal fragment lime floatstone with matrix of skeletal fragment lime wackestone, very pale orange } 10 \mathrm{YR} 8 / 2 \text { to grayish } \\
\text { orange } 10 \mathrm{YR} 7 / 4 \text {; mainly clay to coarse, ranges from clay to pebble; mollusks and branching corals; } 20 \text { percent vuggy and } \\
\text { moldic porosity; high hydraulic conductivity. }\end{array}$ \\
\hline $78.3-80.0$ & $\begin{array}{l}\text { Skeletal fragment lime wackestone, very pale orange } 10 \mathrm{YR} 8 / 2 \text { to grayish orange } 10 \mathrm{YR} 7 / 4 \text {; mainly clay to coarse grain } \\
\text { size, ranges from clay to coarse; mollusks and gastropods; } 20 \text { percent vuggy and moldic porosity; high hydraulic conductiv- } \\
\text { ity; one 5-millimeter-thick lamination of very fine quartz sand. }\end{array}$ \\
\hline $80.0-81.0$ & No recovery. \\
\hline $81.0-84.8$ & $\begin{array}{l}\text { Mollusk and branching-coral lime floatstone with matrix of skeletal fragment, peloid lime wackestone, very pale orange } \\
10 \text { YR } 8 / 2 \text { to grayish orange } 10 \text { YR } 7 / 4 \text {; mainly clay to coarse grain size, ranges from clay to pebble; } 20 \text { percent moldic } \\
\text { porosity, vuggy and solution-channel porosity; high hydraulic conductivity; root molds. }\end{array}$ \\
\hline $84.8-89.0$ & $\begin{array}{l}\text { Skeletal fragment, quartz-sand-rich lime grainstone; mottled very pale orange } 10 \mathrm{YR} 8 / 2 \text { and grayish orange } 10 \mathrm{YR} 7 / 4 \text {; } \\
\text { mainly very fine to coarse grain size; ranges from very fine to pebble; } 20 \text { percent very fine to medium quartz sand, red algae, } \\
\text { mollusks, gastropods and branching corals; } 20 \text { percent interparticle and moldic porosity, moderate hydraulic conductivity. }\end{array}$ \\
\hline $89.0-92.8$ & $\begin{array}{l}\text { Skeletal-fragment lime floatstone with matrix of skeletal fragment, quartz-sand-rich lime grainstone, mottled very pale } \\
\text { orange } 10 \mathrm{YR} 8 / 2 \text {, grayish orange } 10 \mathrm{YR} 7 / 4 \text { to very light gray N } 8 \text {; mainly very fine to pebble grain size, ranges from very } \\
\text { fine to pebble; } 10 \text { to } 20 \text { percent very fine to medium quartz sand, red algae, gastropods and mollusks; } 20 \text { percent interparticle } \\
\text { and moldic porosity; moderate hydraulic conductivity. }\end{array}$ \\
\hline $92.8 \cdot 95.0$ & No recovery. \\
\hline $95.0-97.0$ & $\begin{array}{l}\text { Quartz-sand-rich, skeletal lime grainstone, very light gray N8; mainly very fine to coarse grain size, ranges from very fine to } \\
\text { pebble; } 20 \text { percent very fine to fine quartz sand, mollusks and gastropods; } 20 \text { percent moldic, interparticle and vuggy poros- } \\
\text { ity; moderate hydraulic conductivity. }\end{array}$ \\
\hline $97.0-101.0$ & No recovery. \\
\hline
\end{tabular}




\section{Deering Estate Park No. 1 Core}

\begin{tabular}{|c|c|}
\hline $\begin{array}{l}\text { Depth } \\
\text { (feet below } \\
\text { land } \\
\text { surface) }\end{array}$ & Lithologic description \\
\hline $0.0-1.5$ & $\begin{array}{l}\text { Oomoldic lime grainstone, white N9; medium grain size, ranges from fine to medium; well rounded; sparry calcite; } 10 \text { per- } \\
\text { cent oomoldic and interparticle porosity; moderate hydraulic conductivity. }\end{array}$ \\
\hline $1.5-2.0$ & No recovery. \\
\hline $2.0-2.3$ & $\begin{array}{l}\text { Shell fragment-rich clay lime mudstone, pale-yellowish-brown } 10 \text { YR } 6 / 2 \text {; clay grain size, ranges from clay to medium } 10 \\
\text { percent quartz sand; less than } 5 \text { percent interparticle porosity; very low hydraulic conductivity. }\end{array}$ \\
\hline $2.3-4.5$ & $\begin{array}{l}\text { Quartz sand, pale-yellowish-brown, } 10 \mathrm{YR} 6 / 2 \text { grayish orange } 10 \mathrm{YR} 7 / 4 \text {; fine to medium grain size, ranges from clay to } \\
\text { medium; } 5 \text { percent clay, } 3 \text { percent skeletal fragments, } 2 \text { percent organic material (Holocene roots); } 5 \text { percent interparticle } \\
\text { porosity, low hydraulic conductivity. }\end{array}$ \\
\hline $4.5-5.5$ & $\begin{array}{l}\text { Rubble; oolitic-peloid lime grainstone, very pale orange } 10 \mathrm{YR} 8 / 2 \text { grayish orange } 10 \mathrm{YR} 7 / 4 \text {; fine to medium grain size, } \\
\text { ranges from fine to medium; } 10 \text { percent oomoldic porosity, pelmoldic and interparticle porosity; moderate hydraulic conduc- } \\
\text { tivity. }\end{array}$ \\
\hline $5.5-8.0$ & $\begin{array}{l}\text { Oolitic-peloid lime grainstone, very pale orange } 10 \mathrm{YR} 8 / 2 \text { grayish orange } 10 \mathrm{YR} 7 / 4 \text {; fine to medium grain size, ranges from } \\
\text { fine to medium; } 20 \text { percent oomoldic and pelmoldic porosity; moderate hydraulic conductivity. }\end{array}$ \\
\hline $8.0-10.0$ & 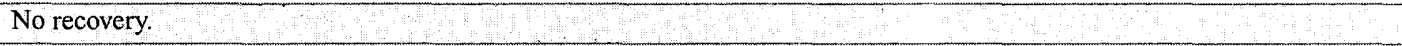 \\
\hline $10.0-12.0$ & $\begin{array}{l}\text { Oolitic-peloid lime grainstone, very pale orange } 10 \mathrm{YR} 8 / 2 \text {; fine to medium grain size, ranges from fine to medium; mollusks } \\
\text { and gastropods; } 20 \text { percent oomoldic and pelmoldic porosity; high hydraulic conductivity. }\end{array}$ \\
\hline $12.0-15.0$ & No recovery: \\
\hline $15.0-15.3$ & $\begin{array}{l}\text { Bryozoan framestone, very pale orange } 10 \text { YR } 8 / 2 \text {; pebble grain size; skeletal fragments; } 15 \text { percent interparticle porosity; } \\
\text { moderate hydraulic conductivity. }\end{array}$ \\
\hline $15.3-15.5$ & $\begin{array}{l}\text { Laminate calcrete (exposure surface); moderate yellowish brown } 10 \text { YR } 5 / 4 \text {; clay grain size; micrite; less than } 5 \text { percent } \\
\text { porosity; very low hydraulic conductivity. }\end{array}$ \\
\hline $15.5-16.7$ & $\begin{array}{l}\text { Skeletal lime floatstone with a matrix of quartz sand-rich, peneroplid, peloid, skeletal fragment lime grainstone, very pale } \\
\text { orange } 10 \text { YR } 8 / 2 \text {; fine to coarse grain size, ranges from fine to coarse; } 15 \text { percent interparticle and vuggy porosity; moderate } \\
\text { hydraulic conductivity. }\end{array}$ \\
\hline $16.7-20.0$ & No recovery. \\
\hline $20.0-20.5$ & $\begin{array}{l}\text { Skeletal-fragment lime grainstone, very pale orange } 10 \mathrm{YR} 8 / 2 \text {; fine to medium grain size, ranges from very fine to coarse; } \\
30 \text { percent very fine to fine quartz sand; } 25 \text { percent vuggy porosity, riddled with solution channels; very high hydraulic con- } \\
\text { ductivity. }\end{array}$ \\
\hline $20.5-21.8$ & No recovery. \\
\hline $21.8-22.2$ & $\begin{array}{l}\text { Skeletal fragment, quartz-sand-rich lime grainstone, very pale orange } 10 \mathrm{YR} 8 / 2 \text {; fine to medium grain size, ranges from very } \\
\text { fine to coarse; } 5 \text { percent very fine to medium quartz sand; } 20 \text { percent vuggy porosity; high hydraulic conductivity. }\end{array}$ \\
\hline $22.2-23.5$ & $\begin{array}{l}\text { Monastrea lime framestone, very pale orange } 10 \text { YR } 8 / 2 ; \text { cobble grain size; } 25 \text { percent intraparticle porosity; very high } \\
\text { hydraulic conductivity. }\end{array}$ \\
\hline $23.5-25.0$ & No recovery. \\
\hline $25.0-25.5$ & $\begin{array}{l}\text { Monastrea lime framestone, very pale orange } 10 \text { YR } 8 / 2 ; \text { cobble grain size; } 25 \text { percent intraparticle porosity; very high } \\
\text { hydraulic conductivity. }\end{array}$ \\
\hline $25.5-26.5$ & No recovery. \\
\hline $26.5-27.0$ & 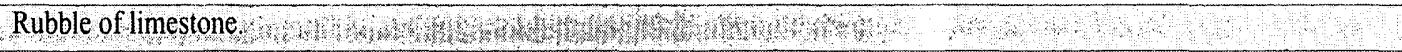 \\
\hline $27.0-27.5$ & $\begin{array}{l}\text { Quartz sand-rich, skeletal-fragment lime packstone, very pale orange } 10 \mathrm{YR} 8 / 2 \text {; clay and fine to medium grain size; ranges } \\
\text { from clay to pebble; } 10 \text { percent very fine to fine quartz sand; } 25 \text { percent vuggy porosity, riddled with solution channels; very } \\
\text { high hydraulic conductivity. }\end{array}$ \\
\hline $27.5-28.2$ & $\begin{array}{l}\text { Skeletal-fragment lime floatstone with matrix of mollusk, miliolid, quartz-sand-rich lime packstone and wackestone; very } \\
\text { light gray N8; clay and fine to medium grain size, ranges from clay to pebble; } 10 \text { percent very fine to fine quartz sand; } 10 \\
\text { percent vuggy porosity, low hydraulic conductivity. }\end{array}$ \\
\hline $28.2-31.0$ & No recovery. \\
\hline $31.0-32.7$ & $\begin{array}{l}\text { Lime-mud-rich quartz sandstone; very light gray N8; clay and fine to medium grain size, ranges from clay to granule; } 60 \\
\text { percent very fine to medium quartz sand; } 15 \text { percent lime mud; } 25 \text { percent mollusks and skeletal fragments; } 20 \text { percent } \\
\text { vuggy porosity, riddled with solution channels; very high hydraulic conductivity. }\end{array}$ \\
\hline $32.7-35.0$ & $\begin{array}{l}\text { Lime-mud-rich queers sandstone, very light gray N8; clay and very fine to medium grain size, ranges from clay to granule; } \\
60 \text { percent very fine to medium quartz sand, } 15 \text { percent lime mud, } 25 \text { percent mollusks and skeletal fragments; } 15 \text { percent } \\
\text { vuggy porosity, minor solution channels; high hydraulic conductivity. }\end{array}$ \\
\hline
\end{tabular}




\begin{tabular}{|c|c|}
\hline $\begin{array}{l}\text { Depth } \\
\text { (feet below } \\
\text { land } \\
\text { surface) }\end{array}$ & Lithologic description \\
\hline $35.0-35.4$ & $\begin{array}{l}\text { Mollusk lime floatstone with a matrix of skeletal fragment, quartz-rich lime packstone, very pale orange } 10 \mathrm{YR} 8 / 2 \text {; clay and } \\
\text { very fine to medium grain size, ranges from clay to pebble; } 30 \text { percent very fine to medium quartz sand, mollusks, gastro- } \\
\text { pods and dasyclad algae; } 15 \text { percent moldic and root-mold porosity; moderate hydraulic conductivity; abundant millimeter- } \\
\text { wide root molds suggest an exposure surface at } 35 \text { feet. }\end{array}$ \\
\hline $35.4-35.6$ & $\begin{array}{l}\text { Skeletal fragment floatstone with a matrix of skeletal-fragment-rich quartz sand, very light gray } \mathrm{N} 8 \text {; clay and very fine to } \\
\text { medium grain size, ranges from very fine to pebble; very fine to medium quartz sand; } 20 \text { percent vuggy porosity; high } \\
\text { hydraulic conductivity. }\end{array}$ \\
\hline $35.6-37.5$ & $\begin{array}{l}\text { Skeletal lime floatstone with matrix of skeletal, quartz-sand-rich lime packstone, very pale orange } 10 \mathrm{YR} 8 / 2 \text {; clay and } \\
\text { coarse to pebble grain size, ranges from clay to pebble; } 10 \text { percent very fine to medium quartz sand, gastropods, mollusks } \\
\text { and peneroplids; } 15 \text { percent moldic and vuggy porosity; moderate hydraulic conductivity. }\end{array}$ \\
\hline $37.5-37.8$ & $\begin{array}{l}\text { Branching Porites lime rudstone with matrix of skeletal lime grainstone; very pale orange } 10 \mathrm{YR} 8 / 2 \text {; fine to medium and } \\
\text { pebble to cobble grain size, ranges from clay to cobble; } 10 \text { percent very fine to medium quartz sand; } 20 \text { percent interparticle } \\
\text { porosity; moderate hydraulic conductivity. }\end{array}$ \\
\hline $37.8-38.8$ & $\begin{array}{l}\text { Skeletal-fragment lime packstone, very pale orange } 10 \mathrm{YR} 8 / 2 \text {; clay and coarse to pebble grain size, ranges from clay to peb- } \\
\text { ble; } 15 \text { percent very fine to medium quartz sand; mollusks, peneroplids and miliolids; } 20 \text { percent moldic and vuggy porosity; } \\
\text { moderate hydraulic conductivity. }\end{array}$ \\
\hline $38.8-39.2$ & $\begin{array}{l}\text { Skeletal fragment floatstone with matrix of skeletal-fragment quartz sandstone; very light gray N8; clay and very fine to } \\
\text { medium grain size, ranges from clay to pebble; }\end{array}$ \\
\hline $39.2-39.8$ & $\begin{array}{l}\text { Gastropod lime floatstone with matrix of gastropod and mollusk lime packstone, very pale orange } 10 \mathrm{YR} 8 / 2 \text {; clay and very } \\
\text { fine to fine and pebble grain size, ranges from clay to pebble; } 10 \text { percent very fine to fine quartz sand, gastropods and mol- } \\
\text { lusks; } 25 \text { percent moldic porosity; moderate hydraulic conductivity; probable lacustrine environment. }\end{array}$ \\
\hline $39.8-39.9$ & $\begin{array}{l}\text { Peneroplid-rich floatstone with matrix of quartz sandstone, very pale orange } 10 \mathrm{YR} 8 / 2 \text {; clay and very fine to medium and } \\
\text { pebble grain size; ranges from clay to pebble; } 80 \text { percent very fine to medium quartz sand, peneroplids; } 20 \text { percent vuggy } \\
\text { and interparticle porosity; high hydraulic conductivity. }\end{array}$ \\
\hline $39.9-40.0$ & $\begin{array}{l}\text { Laminated calcrete, pale-yellowish-brown } 10 \text { YR } 6 / 2 \text {; clay grain size, ranges from clay to very fine; } 10 \text { percent silt to very } \\
\text { fine quartz grains; } 5 \text { percent porosity; very low hydraulic conductivity; exposure surface at } 39.9 \text { feet. }\end{array}$ \\
\hline $40.0-41.0$ & $\begin{array}{l}\text { Skeletal lime floatstone with matrix of skeletal-fragment lime grainstone; very pale orange } 10 \mathrm{YR} 8 / 2 \text {; medium to granule } \\
\text { grain size, ranges from very fine to pebble; peneroplids, mollusks and gastropods; } 25 \text { percent interparticle and vuggy poros- } \\
\text { ity; high hydraulic conductivity. }\end{array}$ \\
\hline $41.0-45.0$ & $\begin{array}{l}\text { Skeletal floatstone with matrix of quartz sandstone, very pale orange } 10 \mathrm{YR} 8 / 2 \text {; very fine to medium grain size, ranges from } \\
\text { very fine to pebble; mollusks and dasyclad algae; } 15 \text { percent moldic and vuggy porosity; moderate hydraulic conductivity. }\end{array}$ \\
\hline $45.0-49.0$ & No recovery. \\
\hline $49.0-49.5$ & $\begin{array}{l}\text { Mollusk floatstone with matrix of skeletal fragment quartz sandstone, very light gray N8; fine to medium grain size, ranges } \\
\text { from silt to pebble; } 70 \text { percent very fine to fine quartz sand, mollusks, benthic foraminifers and branching Porites; } 20 \text { per- } \\
\text { cent moldic and vuggy porosity; high hydraulic conductivity. }\end{array}$ \\
\hline $49.5-50.5$ & $\begin{array}{l}\text { Skeletal, quartz-sand-rich lime grainstone, very pale orange } 10 \mathrm{YR} 8 / 2 \text {; very fine to medium grain size, ranges from silt to } \\
\text { pebble; } 30 \text { percent very fine to medium sand, mollusks and gastropods; } 15 \text { percent moldic porosity; moderate hydraulic con- } \\
\text { ductivity. }\end{array}$ \\
\hline $50.5-55.0$ & No recovery. \\
\hline $55.0-57.5$ & $\begin{array}{l}\text { Skeletal fragment floatstone with matrix of skeletal-fragment-rich quartz sandstone, very light gray N8; very fine to fine } \\
\text { grain size, ranges from very fine to pebble; } 50 \text { percent very fine to fine quartz grains, mollusks and gastropods; } 15 \text { percent } \\
\text { moldic and vuggy porosity; moderate hydraulic conductivity. }\end{array}$ \\
\hline $57.5-58.7$ & $\begin{array}{l}\text { Skeletal floatstone with matrix of skeletal-fragment-rich quartz sandstone, very light gray N8; very fine to fine grain size, } \\
\text { ranges from very fine to pebble; } 60 \text { percent very fine to fine quartz grains, mollusks, dasyclad algae, benthic foraninifers } \\
\text { and bryozoans; } 15 \text { percent moldic and vuggy porosity; moderate hydraulic conductivity. }\end{array}$ \\
\hline $58.7-61.0$ & No recovery. \\
\hline $61.0-61.7$ & $\begin{array}{l}\text { Rubble of skeletal floatstone with matrix of skeletal-fragment-rich quartz sandstone; very light gray N8; very fine to fine } \\
\text { grain size, ranges from very fine to pebble; } 60 \text { percent very fine to fine quartz sand, mollusks, dasyclad algae, benthic fora- } \\
\text { minifers and bryozoans; } 15 \text { percent moldic and vuggy porosity; moderate hydraulic conductivity. }\end{array}$ \\
\hline $61.7-67.0$ & $\begin{array}{l}\text { Skeletal-fragment lime floatstone with matrix of quartz-sand-rich skeletal lime packstone, very pale orange } 10 \mathrm{YR} 8 / 2 \text {; very } \\
\text { fine to fine grain size, ranges from very fine to pebble; } 10 \text { to } 20 \text { percent very fine to fine quartz sand, mollusks and gastro- } \\
\text { pods; } 15 \text { percent moldic porosity, minor vugs; moderate hydraulic conductivity. }\end{array}$ \\
\hline $67.0-68.0$ & $\begin{array}{l}\text { Rubble of skeletal-fragment-rich quartz sandstone, very light gray N8; very fine to fine grain size, ranges from very fine to } \\
\text { pebble; } 15 \text { percent vuggy porosity; moderate hydraulic conductivity. }\end{array}$ \\
\hline
\end{tabular}




\begin{tabular}{|c|c|}
\hline $\begin{array}{l}\text { Depth } \\
\text { (feet below } \\
\text { land } \\
\text { surface) }\end{array}$ & Lithologic description \\
\hline $68.0-70.8$ & $\begin{array}{l}\text { Mollusk skeletal lime floatstone with matrix of skeletal-fragment lime grainstone, very pale orange } 10 \mathrm{YR} 8 / 2 \text {; very fine to } \\
\text { medium grain size, ranges from very fine to pebble; } 10 \text { percent very fine to fine quartz sand, mollusks, gastropods, branch- } \\
\text { ing Porites, bryozoans and sand dollars; } 20 \text { percent moldic and vuggy porosity, high hydraulic conductivity. }\end{array}$ \\
\hline $70.8-70.8$ & $\begin{array}{l}\text { Laminate calcrete, grayish orange } 10 \mathrm{YR} 7 / 4 \text {; clay to silt grain size, ranges from clay to silt; less than } 5 \text { percent porosity, very, } \\
\text { low hydraulic conductivity; } 1 \text {-millimeter-thick calcrete, exposure surface at } 70.8 \text { feet. }\end{array}$ \\
\hline $70.8-73.0$ & $\begin{array}{l}\text { Mollusk, skeletal-fragment lime floatstone with matrix of skeletal-fragment lime grainstone, very pale orange } 10 \mathrm{YR} 8 / 2 \text { and } \\
\text { very light gray N8; very fine to medium grain size, ranges from very fine to pebble; } 10 \text { percent very fine to fine quartz sand, } \\
\text { mollusks and gastropods; } 20 \text { percent moldic and vuggy porosity; high hydraulic conductivity. }\end{array}$ \\
\hline $73.0-75.0$ & No recovery \\
\hline $75.0-75.5$ & $\begin{array}{l}\text { Mollusk floatstone with matrix of skeletal-fragment-rich quartz sandstone, very light gray N8; very fine to fine grain size, } \\
\text { ranges from very fine to pebble; } 70 \text { percent very fine to fine quartz sand; mollusks and gastropods; } 15 \text { percent moldic and } \\
\text { vuggy porosity; moderate hydraulic conductivity. }\end{array}$ \\
\hline $75.5-84.0$ & No recovery. \\
\hline $84.0-85.0$ & $\begin{array}{l}\text { Skeletal-fragment lime packstone and mollusk, skeletal-fragment lime floatstone with matrix of skeletal lime packstone; } \\
\text { very pale orange } 10 \mathrm{YR} 8 / 2 \text {; clay to pebble grain size, ranges from clay to pebble; } 20 \text { percent very fine to fine quartz sand, } \\
\text { red algae, mollusks and gastropods; } 15 \text { percent moldic and vuggy porosity; moderate hydraulic conductivity; root molds, } \\
\text { possible exposure surface at } 84 \text { feet. }\end{array}$ \\
\hline $85.0-87.0$ & 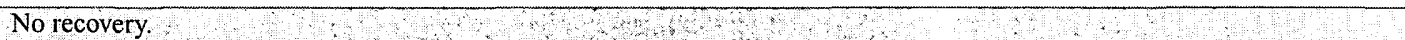 \\
\hline $87.0-88.0$ & $\begin{array}{l}\text { Skeletal-fragment lime floatstone with matrix of skeletal-fragment lime grainstone, very pale orange } 10 \mathrm{YR} 8 / 2 \text {; fine to } \\
\text { medium grain size, ranges from very fine to pebble; } 10 \text { percent very fine quartz sand, red algae; } 15 \text { percent interparticle and } \\
\text { moldic porosity; moderate hydraulic conductivity. }\end{array}$ \\
\hline $88.0-90.0$ & $\begin{array}{l}\text { Skeletal-fragment lime floatstone with matrix of skeletal fragment, quartz-sand-rich lime packstone, very pale orange } 10 \mathrm{YR} \\
8 / 2 \text {; clay to pebble grain size, ranges from clay to pebble; } 10 \text { percent very fine quartz sand, mollusks and gastropods; } 20 \text { per- } \\
\text { cent moldic and vuggy porosity; high hydraulic conductivity. }\end{array}$ \\
\hline $90.0-91.3$ & $\begin{array}{l}\text { Mollusk, skeletal-fragment lime rudstone with matrix of skeletal fragment, quartz-sand-rich lime packstone, very pale } \\
\text { orange } 10 \mathrm{YR} 8 / 2 \text {; clay to pebble grain size, ranges from clay to pebble; } 10 \text { percent very fine to very coarse quartz sand, mol- } \\
\text { lusks and gastropods; } 20 \text { percent moldic and vuggy porosity; high hydraulic conductivity. }\end{array}$ \\
\hline $91.3-93.8$ & No recovery \\
\hline $93.8-95.5$ & $\begin{array}{l}\text { Mollusk, skeletal fragment lime floatstone with matrix of quartz-sand-rich, skeletal-fragment lime packstone and wacke- } \\
\text { stone, very pale orange } 10 \mathrm{YR} 8 / 2 \text {; clay to pebble grain size, ranges from clay to pebble; } 20 \text { percent very fine to fine quartz } \\
\text { sand; } 15 \text { percent moldic and vuggy porosity; moderate hydraulic conductivity. }\end{array}$ \\
\hline $95.5-98.8$ & $\begin{array}{l}\text { Quartz-sand-rich skeletal lime packstone and wackestone, very pale orange } 10 \mathrm{YR} 8 / 2 \text {; clay to granule grain size, ranges } \\
\text { from clay to pebble; } 20 \text { percent very fine to coarse quartz sand; } 10 \text { percent moldic porosity; low hydraulic conductivity. }\end{array}$ \\
\hline $98.8-101.0$ & No recovery. \\
\hline
\end{tabular}




\section{Deering Estate Park No. 2 Core}

\begin{tabular}{|c|c|}
\hline $\begin{array}{l}\text { Depth } \\
\text { (feet below } \\
\text { land } \\
\text { surface) }\end{array}$ & Lithologic description \\
\hline $0.0-1.0$ & No recovery. \\
\hline $1.0-8.0$ & $\begin{array}{l}\text { Rubble of oolitic lime grainstone, very pale orange } 10 \mathrm{YR} 8 / 2 \text {; mainly medium grain size, ranges from fine to pebble; mol- } \\
\text { lusks; } 30 \text { percent oomoldic and probable solution-channel porosity; high hydraulic conductivity. }\end{array}$ \\
\hline $8.0-9.0$ & $\begin{array}{l}\text { Rubble of oolitic lime grainstone, very pale orange } 10 \mathrm{YR} 8 / 2 \text {; mainly medium grain size, ranges from fine to pebble; mol- } \\
\text { lusks; } 30 \text { percent oomoldic and solution-channel porosity; very high hydraulic conductivity. }\end{array}$ \\
\hline $9.0-13.0$ & No recovery. \\
\hline $13.0-15.0$ & $\begin{array}{l}\text { Oolitic lime grainstone, rubble in part, very pale orange } 10 \mathrm{YR} 8 / 2 \text {; mainly medium grain size, ranges from fine to pebble; } \\
\text { mollusks and gastropods; } 30 \text { percent oomoldic and solution-channel porosity; very high hydraulic conductivity. }\end{array}$ \\
\hline $15.0-16.0$ & No recovery. \\
\hline $16.0-17.0$ & $\begin{array}{l}\text { Oolitic lime grainstone, rubble in part, very pale orange } 10 \mathrm{YR} 8 / 2 \text {; mainly medium grain size, ranges from fine to pebble; } \\
\text { mollusks and gastropods; } 30 \text { percent oomoldic and solution-channel porosity; very high hydraulic conductivity. }\end{array}$ \\
\hline $17.0-21.0$ & No recovery \\
\hline $21.0-21.5$ & $\begin{array}{l}\text { Rubble of oolitic lime grainstone, very pale orange } 10 \text { YR } 8 / 2 ; \text { mainly medium grain size, ranges from fine to pebble; mol- } \\
\text { lusks and gastropods; } 30 \text { percent oomoldic and probable solution-channel porosity; very high hydraulic conductivity. }\end{array}$ \\
\hline $21.5-23.0$ & $\begin{array}{l}\text { Calcretized mollusk, peneroplid lime floatstone with skeletal, quartz-sand-rich lime wackestone matrix, very pale orange } \\
10 \mathrm{YR} 8 / 2 \text {, pale-yellowish-orange } 10 \mathrm{YR} 8 / 6 \text {, grayish orange } 10 \mathrm{YR} 7 / 4 \text {, pale-yellowish-brown } 10 \mathrm{YR} 6 / 2 \text {, light-brown } 5 \mathrm{YR} \\
6 / 4 \text {; mainly clay to medium grain size, ranges from clay to pebble; } 10 \text { to } 30 \text { percent accessory grains, very fine to medium } \\
\text { quartz sand; } 10 \text { percent moldic an vuggy porosity; low hydraulic conductivity; subaerial exposure zone, depositional } \\
\text { sequence boundary at } 21.5 \text { feet. }\end{array}$ \\
\hline $23.0-25.5$ & No recovery. \\
\hline $25.5-28.0$ & $\begin{array}{l}\text { Skeletal fragment lime wackestone and mudstone, very pale orange } 10 \mathrm{YR} 8 / 2 \text {, pale-yellowish-orange } 10 \mathrm{YR} 8 / 6 \text {, grayish } \\
\text { orange } 10 \mathrm{YR} 7 / 4 \text {, pale-yellowish-brown } 10 \mathrm{YR} 6 / 2 \text {, light brown } 5 \mathrm{YR} 6 / 4 ; \text { mainly clay to fine grain size, ranges from clay to } \\
\text { pebble; } 10 \text { percent very fine to medium quartz sand; } 25 \text { percent moldic, vuggy and solution-channel porosity; high hydraulic } \\
\text { conductivity; possible reef rock, root molds filled with quartz sand. }\end{array}$ \\
\hline $28.0-29.0$ & $\begin{array}{l}\text { Monastrea lime framestone, very pale orange } 10 \mathrm{YR} 8 / 2 \text {, pale-yellowish-orange } 10 \mathrm{YR} 8 / 6 \text {, grayish orange } 10 \mathrm{YR} 7 / 4 \text {, pale- } \\
\text { yellowish-brown } 10 \mathrm{YR} 6 / 2 \text {; mainly clay to fine and cobble grain size, ranges from clay to cobble; Monastrea coral heads } \\
\text { and possible sponge; } 25 \text { percent moldic, vuggy and solution-channel porosity; high hydraulic conductivity. }\end{array}$ \\
\hline $29.0-30.8$ & No recovery. \\
\hline $30.8-31.1$ & $\begin{array}{l}\text { Skeletal fragment lime wackestone; very pale orange } 10 \mathrm{YR} 8 / 2 \text {, light gray } \mathrm{N} 7 \text {, pale-yellowish-brown } 10 \mathrm{YR} 6 / 2 \text {; mainly clay } \\
\text { to very fine, ranges from clay to coarse; } 15 \text { percent vuggy and solution-channel porosity; moderate hydraulic conductivity. }\end{array}$ \\
\hline $31.1-34.4$ & $\begin{array}{l}\text { Skeletal lime grainstone, packstone and wackestone, very pale orange } 10 \mathrm{YR} 8 / 2 \text {, light gray N7; mollusks, two thin Monas- } \\
\text { trea corals and gastropods; } 5 \text { to } 25 \text { percent very fine to medium quartz sand in lime mud matrix of packstone and wacke- } \\
\text { stone; } 20 \text { percent vuggy and solution-channel porosity; high hydraulic conductivity. }\end{array}$ \\
\hline $34.4-35.8$ & No recovery. \\
\hline $35.8-37.3$ & $\begin{array}{l}\text { Quartz-sand-rich, skeletal lime mudstone and wackestone; very pale orange } 10 \mathrm{YR} 8 / 2 \text {, very light gray N8; mainly clay to } \\
\text { fine, ranges from clay to coarse; } 40 \text { percent very fine to fine quartz sand, mollusks; } 20 \text { percent vuggy and minor solution- } \\
\text { channel porosity; high hydraulic conductivity; solution channels filled with quartz sand, trace root molds lined with lami- } \\
\text { nated calcrete, possible exposure surface and depositional sequence boundary between } 34.4 \text { and } 35.8 \text { feet. }\end{array}$ \\
\hline $37.3-40.5$ & No recovery. \\
\hline $40.5-44.0$ & $\begin{array}{l}\text { Skeletal quartz sandstone and skeletal, quartz-sand-rich lime packstone, very pale orange } 10 \mathrm{YR} 8 / 2 \text {, very light gray N8; } \\
\text { mainly clay to coarse, ranges from clay to pebble; peneroplids and mollusks, quartz sand; } 20 \text { percent vuggy, moldic and } \\
\text { solution channel porosity; high hydraulic conductivity; matrix of sandstone composed of lime mud, quartz sand fills some } \\
\text { solution channels, trace root molds, lined with laminated calcrete. }\end{array}$ \\
\hline $44.0-45.5$ & $\begin{array}{l}\text { Branching-coral lime floatstone and rudstone with quartz-sand-rich, skeletal lime packstone and grainstone matrix, very pale } \\
\text { orange } 10 \mathrm{YR} 8 / 2 \text {, very light gray N8; mainly clay to pebble grain size, ranges from clay to pebble; mollusks, gastropods, } \\
\text { miliolids and peneroplids, } 5 \text { to } 45 \text { percent fine to coarse quartz sand; } 10 \text { percent moldic, vuggy and interparticle porosity; } \\
\text { low hydraulic conductivity; root molds. }\end{array}$ \\
\hline $45.5-48.0$ & $\begin{array}{l}\text { Skeletal lime floatstone and rudstone with quartz-sand-rich lime packstone and grainstone matrix, very pale orange } \\
\text { 10YR } 8 / 2 \text {, very light gray N8; mainly very fine to coarse grain size, ranges from very fine to coarse; mollusks, miliolids, } \\
\text { peneroplids, branching Porites and gastropods, } 10 \text { to } 40 \text { percent fine to coarse quartz sand; } 20 \text { percent interparticle, vuggy, } \\
\text { moldic and very minor solution-channel porosity; moderate hydraulic conductivity; root molds. }\end{array}$ \\
\hline
\end{tabular}




\begin{tabular}{|c|c|}
\hline $\begin{array}{l}\text { Depth } \\
\text { (feet below } \\
\text { land } \\
\text { surface) }\end{array}$ & Lithologic description \\
\hline $48.0-48.5$ & $\begin{array}{l}\text { Gastropod lime floatstone with lime mudstone matrix, pale-yellowish-brown } 10 \mathrm{YR} 6 / 2 ; \text { mainly clay to silt and pebble, } \\
\text { ranges from clay to pebble; } 10 \text { percent moldic porosity; low hydraulic conductivity; lacustrine environment. }\end{array}$ \\
\hline $48.5-48.8$ & $\begin{array}{l}\text { Skeletal lime floatstone with quartz-sand-rich skeletal lime packstone matrix, very pale orange } 10 \mathrm{YR} 8 / 2 \text {; mainly clay to } \\
\text { fine to coarse quartz sand, mollusks and branching corals; } 15 \text { percent moldic and vuggy porosity; moderate hydraulic con- } \\
\text { ductivity. }\end{array}$ \\
\hline $48.8-49.2$ & $\begin{array}{l}\text { Skeletal, quartz-sand-rich lime wackestone and packstone; very pale orange } 10 \mathrm{YR} 8 / 2 \text {; mainly clay to fine grain size, ranges } \\
\text { from clay to fine; } 20 \text { percent very fine to coarse quartz sand, peneroplids; } 10 \text { percent moldic porosity; low hydraulic conduc- } \\
\text { tivity. }\end{array}$ \\
\hline $49.2-50.0$ & Skeletal quartz-sand-rich \\
\hline $50.0-51.0$ & $\begin{array}{l}\text { Skeletal quartz sandstone, light gray N7 to very light gray N8; mainly clay and very fine to coarse grain size; ranges from } \\
\text { clay to pebble, quartz grains are very fine to coarse; mollusks and peneroplids; } 20 \text { percent interparticle, vuggy and solution- } \\
\text { channel porosity; moderate hydraulic conductivity; lime mud matrix. }\end{array}$ \\
\hline $51.0-54.4$ & No recovery. \\
\hline $54.4-57.5$ & $\begin{array}{l}\text { Skeletal quartz sandstone and quartz-sand-rich lime packstone, very pale orange } 10 \mathrm{YR} 8 / 2 \text {, light gray N7; mainly clay and } \\
\text { very fine to medium grain size, ranges from clay to pebble, quartz grains are very fine to medium; peneroplids, mollusks and } \\
\text { gastropods, } 40 \text { to } 70 \text { percent quartz sand; } 15 \text { percent vuggy and interparticle porosity; low bydraulic conductivity. }\end{array}$ \\
\hline $57.5-60.5$ & No recovery. \\
\hline $60.5-62.5$ & $\begin{array}{l}\text { Skeletal lime rudstone with quartz-sand-rich lime packstone matrix and quartz-sand-rich, skeletal lime wackestone, very } \\
\text { pale orange } 10 \mathrm{YR} 8 / 2 \text {, light gray } 7 \text {; mainly clay to fine grain size, ranges from clay to pebble; peneroplids, mollusks, gas- } \\
\text { tropods and dasyclad algae; } 40 \text { percent very fine to medium quartz sand; } 20 \text { percent moldic, interparticle and solution-chan- } \\
\text { nel porosity; moderate hydraulic conductivity; subaerial exposure surface (depositional sequence boundary) at } 60.7 \text { feet, } \\
\text { below surface are root molds lined with laminated calcrete. }\end{array}$ \\
\hline $62.5-70.5$ & No recovery. \\
\hline $70.5-71.0$ & $\begin{array}{l}\text { Skeletal, molluscan lime floatstone with quartz-sand-rich, skeletal lime grainstone, very pale orange } 10 \mathrm{YR} 8 / 2 \text { and light gray } \\
\mathrm{N} 7 \text {; mainly very fine to coarse grain size, ranges from fine to pebble; } 10 \text { to } 30 \text { percent very fine to fine quartz sand, mollusks } \\
\text { and gastropods; } 15 \text { percent moldic porosity; low hydraulic conductivity. }\end{array}$ \\
\hline $71.0-74.5$ & $\begin{array}{l}\text { Skeletal, molluscan lime floatstone with quartz-sand-rich, skeletal lime packstone, very pale orange } 10 \mathrm{YR} 8 / 2 \text { and light gray } \\
\text { N7; mainly clay to coarse grain size, ranges from clay to pebble; } 10 \text { to } 30 \text { percent very fine to fine quartz sand, mollusks, } \\
\text { gastropods and one branching coral; } 15 \text { percent moldic porosity; low hydraulic conductivity. }\end{array}$ \\
\hline $74.5-75.5$ & $\begin{array}{l}\text { Skeletal, molluscan lime floatstone with quartz-sand-rich, skeletal lime packstone, very pale orange } 10 \mathrm{YR} 8 / 2 \text { and light gray } \\
\mathrm{N} 7 \text {; mainly clay to coarse grain size, ranges from clay to pebble; } 10 \text { to } 30 \text { percent very fine to fine quartz sand, mollusks and } \\
\text { gastropods; } 15 \text { percent moldic porosity; low hydraulic conductivity. }\end{array}$ \\
\hline $75.5-80.5$ & No recovery. \\
\hline $80.5-81.5$ & $\begin{array}{l}\text { Skeletal molluscan, quartz-sand-rich lime grainstone, light gray } \mathrm{N} 7 \text {; very fine to medium grain size, ranges from silt to } \\
\text { medium; } 20 \text { percent very fine to fine quartz sand, mollusks, gastropods and red algae; } 15 \text { percent moldic and vuggy porosity, } \\
\text { low hydraulic conductivity. }\end{array}$ \\
\hline $81.5-84.8$ & $\begin{array}{l}\text { Skeletal, molluscan lime floatstone with sleekly, quartz-sand-rich lime grainstone, very pale orange } 10 \mathrm{YR} 8 / 2 \text {; very fine to } \\
\text { pebble, ranges from silt to pebble; } 10 \text { to } 30 \text { percent very fine to fine quartz sand, mollusks, gastropods and red algae; } 15 \text { per- } \\
\text { cent moldic and vuggy porosity; low hydraulic conductivity. }\end{array}$ \\
\hline $84.8-85.5$ & $\begin{array}{l}\text { Skeletal, molluscan lime floatstone with skeletal, quartz-sand-rich lime grainstone; very pale orange } 10 \mathrm{YR} 8 / 2 \text {; very fine to } \\
\text { pebble, ranges from silt to pebble; } 10 \text { to } 30 \text { percent very fine to fine quartz sand, mollusks, gastropods and red algae; } 20 \text { per- } \\
\text { cent moldic and vuggy porosity; moderate hydraulic conduetivity. }\end{array}$ \\
\hline $85.5-90.5$ & No recovery. \\
\hline $90.5-99.5$ & $\begin{array}{l}\text { Skeletal, mollusk lime rudstone with skeletal, quartz-sand-rich lime packstone matrix, light gray N7, very pale orange } 10 \mathrm{YR} \\
8 / 2 \text {; mainly clay to pebble grain size; ranges from clay to pebble; } 5 \text { to } 25 \text { percent very fine to very coarse quartz sand with } \\
\text { uncommon very coarse quartz sand mollusks, gastropods, red algae, sand dollars, echinoid spines; } 20 \text { percent moldic poros- } \\
\text { ity; low hydraulic conductivity; } 2 \text {-inch-thick laminations at } 91.5 \text { and } 92 \text { feet, composed of gastropod mollusk lime rudstone } \\
\text { with quartz-sand-rich skeletal wackestone and packstone matrix, very pale orange } 10 Y \mathrm{R} 8 / 2 \text { and pale-yellowish-brown } \\
10 \mathrm{YR} 6 / 2 \text {, possibly deposited in a lacustrine environment. }\end{array}$ \\
\hline $99.5-101.5$ & No recovery. \\
\hline
\end{tabular}




\section{High Hope Farms Core}

\begin{tabular}{|c|c|}
\hline $\begin{array}{l}\text { Depth } \\
\text { (feet below } \\
\text { land } \\
\text { surface) }\end{array}$ & Lithologic description \\
\hline $0.0-0.5$ & $\begin{array}{l}\text { Mud and Holocene roots, pale-yellowish-brown } 10 \mathrm{YR} 6 / 2 \text {; clay to very fine grain size; less than } 5 \text { percent microporosity; } \\
\text { low hydraulic conductivity. }\end{array}$ \\
\hline $0.5-2.5$ & $\begin{array}{l}\text { Highly weathered chalky limestone, very pale orange } 10 \text { YR } 8 / 2 \text {; clay to silt grain size; cerithid or serpulid tubes; } 20 \text { percent } \\
\text { microporosity; moderate hydraulic conductivity. }\end{array}$ \\
\hline $2.5-3.5$ & No recovery. \\
\hline $3.5-7.5$ & $\begin{array}{l}\text { Rubble of chalky oolitic, oomoldic lime grainstone, very pale orange } 10 \mathrm{YR} 8 / 2 \text {; clay to medium grain size; ranges from clay } \\
\text { to granule; gastropods and mollusks; } 20 \text { percent microporosity and moldic porosity; moderate hydraulic conductivity. }\end{array}$ \\
\hline $7.5-7.6$ & $\begin{array}{l}\text { Rubble of laminated calcrete, light brown } 5 \text { YR } 5 / 6 \text {; clay to very fine grain size, ranges from clay to very fine; } 15 \text { percent } \\
\text { porosity; low hydraulic conductivity; exposure surface. }\end{array}$ \\
\hline $7.6-8.8$ & $\begin{array}{l}\text { Rubble of oomoldic, pelmoldic lime grainstone, light brown } 5 \text { YR } 5 / 6(?) ; 25 \text { percent oomoldic porosity, pelmoldic and vuggy } \\
\text { porosity; high hydraulic conductivity. }\end{array}$ \\
\hline $8.8-13.0$ & No recovery. \\
\hline $13.0-15.0$ & $\begin{array}{l}\text { Rubble of skeletal fragment, mollusk, gastropod lime floatstone with matrix of oomoldic, pelmoldic lime grainstone; very } \\
\text { pale orange } 10 \mathrm{YR} 8 / 2 \text {; very fine to fine grain size, ranges from very fine to pebble; } 30 \text { percent oomoldic, pelmoldic and } \\
\text { vuggy porosity; high hydraulic conductivity. }\end{array}$ \\
\hline $15.0-15.7$ & $\begin{array}{l}\text { Skeletal fragment, mollusk, gastropod lime floatstone with matrix of oomoldic, pelmoldic lime grainstone, very pale orange } \\
10 \mathrm{YR} 8 / 2 \text {; very fine to fine grain size, ranges from very fine to pebble; } 30 \text { percent oomoldic, pelmoldic and vuggy porosity; } \\
\text { high hydraulic conductivity. }\end{array}$ \\
\hline $15.7-18.0$ & No recovery. \\
\hline $18.0-18.7$ & $\begin{array}{l}\text { Rubble of skeletal fragment lime floatstone with matrix of lime mudstone, mottled very pale orange } 10 \mathrm{YR} 8 / 2 \text { to grayish } \\
\text { orange } 10 \mathrm{YR} 7 / 4 \text {; clay grain size, ranges from clay to very fine; } 20 \text { percent root-mold, skeletal-fragment mold and vuggy } \\
\text { porosity; high hydraulic conductivity; laminated calcrete lines root molds, probable exposure surface at } 18 \text { feet. }\end{array}$ \\
\hline $18.7-20.0$ & $\begin{array}{l}\text { Moldic, skeletal-fragment lime floatstone with matrix of quartz-sand-rich lime mudstone, mottled very pale orange } 10 \mathrm{YR} \\
8 / 2 \text { to grayish orange } 10 \mathrm{YR} 7 / 4 \text {; clay grain size; ranges from clay to granule; } 5 \text { percent very fine to fine quartz sand, mol- } \\
\text { lusks; } 20 \text { percent root-mold and skeletal-fragment moldic and vuggy porosity; high hydraulic conductivity; supratidal or } \\
\text { tidal mudstones. }\end{array}$ \\
\hline $20.0-23.0$ & No recovery. \\
\hline $23.0-27.0$ & $\begin{array}{l}\text { Skeletal fragment, mollusk, benthic-foraminifer lime floatstone with matrix of quartz-sand-rich, mollusk lime wackestone } \\
\text { and packstone, mottled very pale orange } 10 \mathrm{YR} 8 / 2 \text { to grayish orange } 10 \mathrm{YR} 7 / 4 \text {; clay and very fine to fine; ranges from clay } \\
\text { to pebble; } 30 \text { percent very fine to fine quartz sand; } 20 \text { percent moldic and vuggy porosity; high hydraulic conductivity; } \\
\text { equant limpid calcite lines interclast pores and vugs. }\end{array}$ \\
\hline $27.0-30.0$ & $\begin{array}{l}\text { Breccia containing clasts of lime-mud-rich quartz sandstone and quartz-sand-rich lime mudstone, mottled very pale orange } \\
10 \mathrm{YR} 8 / 2 \text {, grayish orange } 10 \mathrm{YR} 7 / 4 \text { to dark-yellowish-orange } 10 \mathrm{YR} 6 / 6 \text {; clay and very fine to fine, ranges from clay to } \\
\text { medium; } 40 \text { percent very fine to fine quartz sand; } 20 \text { percent interclast and vuggy porosity; very high hydraulic conductivity; } \\
\text { equant limpid calcite lines interclast pores and vugs. }\end{array}$ \\
\hline $30.0-30.7$ & $\begin{array}{l}\text { Rubble of quartz-sand-rich lime mudstone, mottled very pale orange } 10 \mathrm{YR} 8 / 2 \text {, grayish orange } 10 \mathrm{YR} 7 / 4 \text { to dark-yellowish- } \\
\text { orange } 10 \mathrm{YR} 6 / 6 \text {; clay and very fine to fine, ranges from clay to medium; } 10 \text { percent very fine to fine quartz sand; } 20 \text { percent } \\
\text { interclast and vuggy porosity; very high hydraulic conductivity. }\end{array}$ \\
\hline $30.7-35.8$ & No recovery. \\
\hline $35.8-36.2$ & Rubble of limestone; probably cave. \\
\hline $36.2-37.0$ & $\begin{array}{l}\text { Gastropod, mollusk lime floatstone with matrix of quartz-sand-rich lime wackestone and packstone light gray N7; clay, very } \\
\text { fine to fine and pebble grain size, ranges from clay to pebble; } 20 \text { to } 40 \text { percent quartz grains, dasyclad algae; } 15 \text { percent mol- } \\
\text { dic porosity; moderate hydraulic conductivity. }\end{array}$ \\
\hline $37.0-38.0$ & $\begin{array}{l}\text { Gastropod, mollusk lime floatstone with matrix of quartz-sand-rich lime wackestone and packstone very pale orange } 10 \mathrm{YR} \\
8 / 2 \text { to very light gray N8; clay, very fine to fine and pebble grain size, ranges from clay to pebble; } 20 \text { to } 40 \text { percent quartz } \\
\text { grains, benthic foraminifers; } 15 \text { percent moldic porosity and minor vugs; moderate hydraulic conductivity. }\end{array}$ \\
\hline $38.0-40.5$ & No recovery. \\
\hline $40.5-41.0$ & $\begin{array}{l}\text { Rubble of quartz-sand-rich, skeletal fragment lime grainstone, very pale orange } 10 \mathrm{YR} 8 / 2 \text {; very fine to fine and pebble grain } \\
\text { size; ranges from very fine to pebble; } 30 \text { percent very fine to fine quartz sand; } 20 \text { percent moldic porosity; moderate hydrau- } \\
\text { lic conductivity. }\end{array}$ \\
\hline
\end{tabular}




\begin{tabular}{|c|c|}
\hline $\begin{array}{l}\text { Depth } \\
\text { (feet below } \\
\text { land } \\
\text { surface) }\end{array}$ & Lithologic description \\
\hline $41.0-42.8$ & $\begin{array}{l}\text { Mollusk lime rudstone and floatstone with matrix of quartz-sand-rich, skeletal lime grainstone, very pale orange } 10 \mathrm{YR} 8 / 2 ; \\
\text { very fine to fine and pebble grain size, ranges from very fine to pebble; } 20 \text { to } 40 \text { percent quartz grains, mollusks, branehing } \\
\text { Porites and gastropods; } 20 \text { percent moldic porosity and minor vugs; moderate hydraulic conductivity. }\end{array}$ \\
\hline $42.8-49.5$ & $\begin{array}{l}\text { Mollusk lime rudstone and floatstone with matrix of quartz-sand-rich, skeletal-fragment lime grainstone and skeletal-frag- } \\
\text { ment-rich quartz sandstone, very pale orange } 10 \mathrm{YR} 8 / 2 \text {; very fine to fine and pebble grain size, ranges from very fine to cob- } \\
\text { ble; } 20 \text { to } 60 \text { percent very fine to fine quartz sand, mollusks, gastropods and benthic foraminifers; } 20 \text { percent moldic and } \\
\text { vuggy porosity; moderate hydraulic conductivity; abundant calcrete line (dark-yellowish-brown } 10 \mathrm{yr} 6 / 6 \text { ) root molds } \\
\text { between } 42.8 \text { and } 47.0 \text { feet, probable exposure surface at } 42.8 \text { feet. }\end{array}$ \\
\hline $49.5-50.5$ & No recovery. \\
\hline $50.5-51.3$ & $\begin{array}{l}\text { Skeletal fragment lime grainstone, very pale orange } 10 \mathrm{YR} 8 / 2 \text {; very fine to fine grain size, ranges from very fine to pebble; } \\
10 \text { percent vuggy and interparticle porosity; moderate hydraulic conductivity. }\end{array}$ \\
\hline $51.3-56.0$ & No recovery. \\
\hline $56.0-57.0$ & $\begin{array}{l}\text { Quartz-sand-rich, skeletal-fragment lime grainstone and skeletal-fragment-rich quartz sandstone, very pale orange } 10 \mathrm{YR} \\
8 / 2 \text {; very fine to medium grain size, ranges from very fine to pebble; } 40 \text { to } 60 \text { percent very fine to fine quartz grains, pener- } \\
\text { oplids; } 15 \text { percent vuggy, moldic and interparticle porosity; moderate hydraulic conductivity. }\end{array}$ \\
\hline $57.0-58.0$ & $\begin{array}{l}\text { Moldic, skeletal-fragment lime grainstone with matrix of quartz-sand-rich, skeletal-fragment lime grainstone and skeletal- } \\
\text { fragment-rich quartz sandstone, very pale orange } 10 \mathrm{YR} 8 / 2 ; \text { very fine to medium and pebble grain size, ranges from very } \\
\text { fine to pebble; } 40 \text { to } 60 \text { percent very fine to fine quartz grains, peneroplids; } 15 \text { percent vuggy, moldic and interparticle poros- } \\
\text { ity; moderate hydraulic conductivity. }\end{array}$ \\
\hline $58.0-60.5$ & No recovery. \\
\hline $60.5-61.5$ & $\begin{array}{l}\text { Skeletal-fragment-rich quartz sandstone and quartz-sand-rich skeletal-fragment lime grainstone, very pale orange } 10 \mathrm{YR} 8 / 2 \text {; } \\
\text { very fine to fine and pebble grain size, ranges from very fine to pebble; } 40 \text { to } 70 \text { percent quartz sand, peneroplids and mol- } \\
\text { lusks; } 20 \text { percent vuggy, moldic and interparticle porosity; moderate hydraulic conductivity. }\end{array}$ \\
\hline $61.5-62.5$ & $\begin{array}{l}\text { Moldic mollusk lime floatstone with matrix of skeletal-fragment-rich quartz sandstone and quartz-sand-rich skeletal-frag- } \\
\text { ment lime grainstone, very pale orange } 10 \text { YR } 8 / 2 \text {; very fine to fine and pebble grain size, ranges from very fine to pebble; } 40 \\
\text { to } 70 \text { percent quartz sand, peneroplids and mollusks one oyster at base; } 20 \text { percent vuggy, moldic and interparticle porosity; } \\
\text { moderate hydraulic conductivity. }\end{array}$ \\
\hline $62.5-67.0$ & No recovery. \\
\hline $67.0-67.2$ & $\begin{array}{l}\text { Skeletal-fragment-rich quartz sandstone, very pale orange } 10 \mathrm{YR} 8 / 2 \text {; very fine to fine grain size, ranges from very fine to } \\
\text { small pebble; } 70 \text { percent very fine to fine quartz sand, gastropods; } 15 \text { percent vuggy, moldic and interparticle porosity; mod- } \\
\text { erate hydraulic conductivity. }\end{array}$ \\
\hline $67.2-70.0$ & No recovery. \\
\hline $70.0-70.4$ & $\begin{array}{l}\text { Oyster lime floatstone with matrix of skeletal-fragment-rich quartz sandstone, very pale orange } 10 \mathrm{YR} 8 / 2 \text {; very fine to fine } \\
\text { grain size, ranges from very fine to pebble; } 70 \text { percent very fine to fine quartz sand; } 20 \text { percent vuggy and interparticle } \\
\text { porosity; moderate hydraulic conductivity. }\end{array}$ \\
\hline $70.4-72.0$ & $\begin{array}{l}\text { Friable quartz sand, very pale orange } 10 \mathrm{YR} 8 / 2 \text {; very fine to fine grain size, ranges from very fine to pebble; } 90 \text { percent very } \\
\text { fine to fine quartz sand, oysters and skeletal fragments; } 20 \text { percent interparticle porosity; moderate hydraulic conductivity. }\end{array}$ \\
\hline $72.0-72.7$ & No recovery. \\
\hline $72.7-73.5$ & $\begin{array}{l}\text { Quartz-sand-rich, skeletal-fragment lime packstone; clay to coarse grain size, ranges from clay to pebble; } 20 \text { percent very } \\
\text { fine to coarse quartz sand, oysters, corals, mollusks and echinoids, } 15 \text { percent vuggy porosity; moderate hydraulic conduc- } \\
\text { tivity. }\end{array}$ \\
\hline $73.5-74.0$ & No recovery. \\
\hline $74.0-74.5$ & $\begin{array}{l}\text { Rubble of mollusk lime floatstone with matrix of skeletal-fragment-rich quartz sandstone, very pale orange } 10 \mathrm{YR} 8 / 2 \text {; very } \\
\text { fine to fine grain size, ranges from very fine to pebble; } 60 \text { percent very fine to fine quartz sand; } 15 \text { percent vuggy and inter- } \\
\text { particle porosity; moderate hydraulic conductivity. }\end{array}$ \\
\hline $74.5-76.0$ & $\begin{array}{l}\text { Mollusk lime floatstone with matrix of skeletal fragment, quartz-sand-rich lime packstone and minor grainstone, very pale } \\
\text { orange } 10 \text { YR } 8 / 2 \text {; very fine to coarse grain size; } 10 \text { to } 20 \text { percent very fine to coarse quartz sand, bryozoans, mollusks, red } \\
\text { algae; } 10 \text { percent vuggy and moldic porosity; low hydraulic conductivity. }\end{array}$ \\
\hline $76.0-76.5$ & $\begin{array}{l}\text { Rubble of mollusk lime floatstone with a matrix of skeletal-fragment quartz sandstone, very pale orange } 10 \mathrm{YR} 8 / 2 \text {; very fine } \\
\text { to fine grain size, ranges from very fine to pebble; } 60 \text { percent very fine to fine quartz sand, oysters; } 15 \text { percent interparticle } \\
\text { and moldic porosity; moderate hydraulic conductivity. }\end{array}$ \\
\hline
\end{tabular}

Mollusk lime floatstone with matrix of skeletal fragment, quartz-sand-rich lime packstone, very pale orange 10YR 8/2; clay

76.5 - 79.0 to pebble grain size; 10 percent very fine to coarse quartz sand, mollusks and gastropods; 15 percent moldic and vuggy porosity; moderate hydraulic conductivity. 
Depth

(feet below

land

Lithologic description

surface)

\begin{tabular}{|c|c|}
\hline $79.0-79.5$ & $\begin{array}{l}\text { Rubble of mollusk lime floatstone with matrix of skeletal fragment quartz sandstone, very pale orange } 10 \mathrm{YR} \text { 8/2; very fine } \\
\text { to fine grain size, ranges from very fine to pebble; } 70 \text { percent very fine to fine quartz sand; } 15 \text { percent vuggy and moldic } \\
\text { porosity; moderate hydraulic conductivity. }\end{array}$ \\
\hline $79.5-81.0$ & No recovery. \\
\hline $81.0-82.5$ & $\begin{array}{l}\text { Partly rubble skeletal fragment, mollusk lime floatstone with quartz-sand-rich lime packstone matrix; very fine to coarse } \\
\text { grain size, ranges from clay to pebble; } 20 \text { percent very fine to coarse quartz sand, red algae; } 15 \text { percent moldic and vuggy } \\
\text { porosity; moderate hydraulic conductivity. }\end{array}$ \\
\hline $82.5-85.0$ & No recovery. \\
\hline $85.0-85.8$ & $\begin{array}{l}\text { Rubble of mollusk, skeletal fragment lime floatstone with quartz-sand-rich lime packstone matrix; clay to medium grain } \\
\text { size, ranges from clay to pebble; } 40 \text { percent very fine to medium quartz sand; } 15 \text { percent moldic and vuggy porosity; moder- } \\
\text { ate hydraulic conductivity. }\end{array}$ \\
\hline $85.8-90.0$ & No recovery. \\
\hline $90.0-91.0$ & $\begin{array}{l}\text { Rubble of mollusk, skeletal fragment lime floatstone with quartz-sand-rich lime packstone matrix; clay to medium grain } \\
\text { size, ranges from clay to pebble; } 45 \text { percent very fine to medium quartz sand; } 15 \text { percent moldic and vuggy porosity; moder- } \\
\text { ate hydraulic conductivity. }\end{array}$ \\
\hline $91.0-101.0$ & No recovery. \\
\hline
\end{tabular}




\section{Mowry Canal Core}

\begin{tabular}{|c|c|}
\hline $\begin{array}{l}\text { Depth } \\
\text { (feet below } \\
\text { land } \\
\text { surface) }\end{array}$ & Lithologic description \\
\hline $0.0-1.0$ & $\begin{array}{l}\text { Rubble of mollusk lime floatstone with peloid, oolitic lime grainstone matrix, very pale orange } 10 \mathrm{YR} 8 / 2 \text {; fine to medium } \\
\text { grain size, ranges from fine to pebble; } 25 \text { percent vuggy, oomoldic and pelmoldic porosity; very high hydraulic conductivity: } \\
\text { root molds }\end{array}$ \\
\hline $1.0-3.0$ & $\begin{array}{l}\text { Rubble of bryozoan lime floatstone with peloid, oolitic lime grainstone matrix, very pale orange } 10 \mathrm{YR} 8 / 2 \text {; fine to medium } \\
\text { and pebble grain size, ranges from fine to pebble; branching bryozoans; } 25 \text { percent oomoldic, intraparticle and vuggy poros- } \\
\text { ity; very high hydraulic conductivity. }\end{array}$ \\
\hline $3.0-4.0$ & $\begin{array}{l}\text { Rubble of oolitic lime grainstone, very pale orange } 10 \mathrm{YR} 8 / 2 \text {; fine to medium grain size; mollusks; } 25 \text { percent oomoldic, } \\
\text { vuggy and root-mold porosity; very high hydraulic conductivity; interval contains a laminated calcrete, less than } 7 \text {-millime- } \\
\text { ters thick, that is partly a blackened soil or phosphatized; pebbles of this darkened calcrete occur above the surface, probably } \\
\text { as a transgressive lag. }\end{array}$ \\
\hline $4.0-5.0$ & No recovery. \\
\hline $5.0-5.8$ & Muddy soil, pale-yellowish-brown 10 YR $6 / 2$; clay to very fine grain size. \\
\hline $5.8-6.8$ & $\begin{array}{l}\text { Rubble of oolitic lime grainstone, very pale orange } 10 \mathrm{YR} 8 / 2 \text {; medium grain size, ranges from medium to pebble; mollusks; } \\
25 \text { percent oomoldic and interparticle porosity; very high hydraulic conductivity. }\end{array}$ \\
\hline $6.8-12.3$ & $\begin{array}{l}\text { Rubble of oolitic lime grainstone, very pale orange } 10 \mathrm{YR} 8 / 2 ; \text { medium grain size, ranges from medium to pebble; mollusks; } \\
25 \text { percent oomoldic, vuggy and interparticle porosity; very high hydraulic conductivity; Holocene black soil near top. }\end{array}$ \\
\hline $12.3-12.5$ & No recovery. \\
\hline $12.5-12.7$ & $\begin{array}{l}\text { Rubble of oolitic lime grainstone, very pale orange } 10 \mathrm{YR} 8 / 2 \text {; medium grain size, ranges from medium to pebble; mollusks; } \\
25 \text { percent oomoldic, vuggy and interparticle porosity; very high hydraulic conductivity. }\end{array}$ \\
\hline $12.7-12.9$ & No recovery. \\
\hline $12.9-15.8$ & $\begin{array}{l}\text { Rubble of oolitic lime grainstone and bryozoan lime floatstone with oolitic lime grainstone matrix, very pale orange } 10 \mathrm{YR} \\
8 / 2 \text {; medium grain size, ranges from medium to pebble; branching bryozoans and mollusks; } 25 \text { percent oomoldic, interparti- } \\
\text { cle and vuggy porosity; very high hydraulic conductivity, very thin laminated calcrete at } 13.1 \text { feet. }\end{array}$ \\
\hline $15.8-17.5$ & $\begin{array}{l}\text { Mollusk lime floatstone with oolitic lime grainstone matrix, very pale orange } 10 \mathrm{YR}, 8 / 2 \text {; medium grain size, ranges from } \\
\text { medium to pebble; gastropods; } 30 \text { percent oomoldic, vuggy and interparticle porosity; very high hydraulic conductivity. }\end{array}$ \\
\hline $17.5-18.0$ & No recovery. \\
\hline $18.0-19.5$ & $\begin{array}{l}\text { Mollusk lime floatstone with burrowed, oolitic lime grainstone matrix, very pale orange } 10 \mathrm{YR} 8 / 2 \text {; medium grain size, } \\
\text { ranges from medium to pebble; gastropods, } 5 \text { percent fine quartz sand in matrix, root molds with laminated calcrete linings } \\
\text { throughout interval; } 30 \text { percent oomoldic, vuggy and interparticle porosity; very high hydraulic conductivity. }\end{array}$ \\
\hline $19.5-21.8$ & No recovery. \\
\hline $21.8-22.6$ & $\begin{array}{l}\text { Mollusk, peneroplid lime floatstone with oolitic grainstone matrix, very pale orange } 10 \mathrm{YR} 8 / 2 \text { to very light gray } \mathrm{N} 8 \text {; } \\
\text { medium and pebble grain size, ranges from medium to pebble; } 5 \text { percent fine quartz sand in matrix; } 30 \text { percent oomoldic, } \\
\text { vuggy and interparticle porosity; very high hydraulic conductivity; root molds with laminated calcrete linings throughout } \\
\text { interval. }\end{array}$ \\
\hline $22.6-22.8$ & $\begin{array}{l}\text { Peneroplid lime floatstone with quartz-sand-rich calcrete matrix, very pale orange } 10 \mathrm{YR} 8 / 2 \text { to very light gray N8; clay to } \\
\text { fine grain size; fine quartz sand in calcrete matrix; } 5 \text { percent interparticle porosity; very low hydraulic conductivity; root } \\
\text { molds with laminated calcrete throughout matrix, possible exposure surface at } 22.6 \text { feet. }\end{array}$ \\
\hline $22.8-26.0$ & No recovery. \\
\hline $26.0-28.0$ & $\begin{array}{l}\text { Mollusk, peneroplid lime floatstone with quartz-sand-rich, skeletal fragment lime grainstone and packstone matrix, very } \\
\text { pale orange } 10 \mathrm{YR} 8 / 2 \text {; clay and very fine to fine, ranges from clay to pebble; peloids, } 25 \text { percent very fine to fine quartz } \\
\text { sand; } 25 \text { percent moldic, vuggy and interparticle porosity; moderate hydraulic conductivity; Caleonassid burrows and peloid } \\
\text { fill. }\end{array}$ \\
\hline $28.0-30.0$ & No recovery. \\
\hline $30.0-32.5$ & $\begin{array}{l}\text { Mollusk, peneroplid lime floatstone and rudstone with skeletal fragment, quartz-sand-rich lime packstone matrix; very pale } \\
\text { orange } 10 \text { YR } 8 / 2 \text {; clay, very fine to fine and pebble, ranges from clay to pebble; } 20 \text { percent very fine to fine quartz sand; } 25 \\
\text { percent moldic and very vuggy porosity; very high hydraulic conductivity; cobble-sized calcrete clasts at base of interval. }\end{array}$ \\
\hline $32.5-32.9$ & $\begin{array}{l}\text { Laminated calcrete, grayish orange } 10 \mathrm{YR} 7 / 4 \text { to moderate yellowish brown } 10 \mathrm{YR} 5 / 4 \text {; clay to very fine; } 5 \text { percent very fine } \\
\text { quartz sand; } 5 \text { percent interparticle porosity; very low hydraulic conductivity; calcrete bounds a significant exposure surface. }\end{array}$ \\
\hline $32.9-34.2$ & $\begin{array}{l}\text { Skeletal lime floatstone with quartz-sand-rich lime packstone matrix, very pale orange } 10 \mathrm{YR} 8 / 2 \text { to very light gray N8; clay } \\
\text { to medium grain size, ranges from clay to pebble; peneroplids and mollusks, } 40 \text { percent very fine to medium quartz sand; } 15 \\
\text { percent moldic and vuggy porosity; moderate hydraulic conductivity; root molds lined with laminated calcrete. }\end{array}$ \\
\hline
\end{tabular}




\begin{tabular}{|c|c|}
\hline $\begin{array}{l}\text { Depth } \\
\text { (feet below } \\
\text { land } \\
\text { surface) }\end{array}$ & Lithologic description \\
\hline $34.2-35.0$ & No recovery. \\
\hline $35.0-37.2$ & $\begin{array}{l}\text { Skeletal fragment, quartz-sand-rich lime grainstone and packstone and quartz sandstone; very pale orange } 10 \mathrm{YR} 8 / 2 \text { to light } \\
\text { gray N7 to very light gray N8; very fine grain size, ranges from clay to pebble; peneroplids and miliolids, } 40 \text { to } 60 \text { percent } \\
\text { very fine quartz sand; } 15 \text { percent vuggy, moldic and interparticle porosity with minor solution channels; moderate hydraulic } \\
\text { conductivity; root molds lined with laminated calcrete near top. }\end{array}$ \\
\hline $37.2-41.0$ & No recovery. \\
\hline $41.0-42.0$ & $\begin{array}{l}\text { Mainly rubble of skeletal-fragment-rich quartz sand, very pale orange } 10 \mathrm{YR} 8 / 2 \text { to very light gray N8; very fine grain size, } \\
\text { ranges from very fine to granule; miliolids and peneroplids, } 30 \text { percent very fine quartz sand; } 20 \text { percent vuggy and interpar- } \\
\text { ticle porosity with minor solution channels; moderate hydraulic conductivity. }\end{array}$ \\
\hline $42.0-47.0$ & No recovery. \\
\hline $47.0-48.3$ & $\begin{array}{l}\text { Quartz-sand-rich, skeletal fragment lime packstone and grainstone, very pale orange } 10 \mathrm{YR} 8 / 2 \text { to very light gray N8; clay to } \\
\text { very fine, ranges from clay to granule; miliolids, peneroplids, mollusks and one coral, } 10 \text { percent very fine to medium quartz } \\
\text { sand; } 20 \text { percent vuggy and moldic porosity with minor solution channels; moderate hydraulic conductivity. }\end{array}$ \\
\hline $48.3-50.7$ & No recovery. \\
\hline $50.7-52.3$ & $\begin{array}{l}\text { Skeletal lime floatstone with quartz-sand-rich, skeletal-fragment lime packstone and grainstone matrix, very pale orange } \\
\text { 10YR } 8 / 2 \text { to very light gray N8; clay and very fine to medium grain size, ranges from clay to pebble; miliolids, mollusks, } \\
\text { gastropods, dasyclad algae and stick-like Porites coral; } 20 \text { percent very fine to medium quartz sand; } 20 \text { percent vuggy, mol- } \\
\text { dic and interparticle porosity; moderate hydraulic conductivity; possible laminated 8-millimeter-thick calcrete at } 51.2 \text { feet, } \\
\text { packstone matrix above and grainstone matrix below calcrete. }\end{array}$ \\
\hline $52.3-54.3$ & $\begin{array}{l}\text { Skeletal fragment, quartz-sand-rich lime packstone, mottled very pale orange } 10 \mathrm{YR} 8 / 2 \text { and pale-yellowish-brown } 10 \mathrm{YR} \\
6 / 2 \text {; clay to medium grain size, ranges from clay to pebble; } 20 \text { percent very fine to medium quartz grains, skeletal fragments, } \\
\text { mollusks, gastropods and miliolids; } 20 \text { percent moldic and vuggy porosity with solution channels; moderate hydraulic con- } \\
\text { ductivity; empty and quartz-sand-rich lime packstone and skeletal fragment quartz-sand-filled lime packstone, 1-millimeter- } \\
\text { thick laminated calcrete lines solution channels. }\end{array}$ \\
\hline $54.3-55.0$ & $\begin{array}{l}\text { Gastropod lime floatstone with quartz-sand-rich lime packstone matrix, pale-yellowish-brown } 10 \mathrm{YR} 6 / 2 \text {; fine to medium } \\
\text { grain size; gastropods, } 20 \text { to } 40 \text { percent fine to medium quartz sand; } 20 \text { percent moldic porosity; moderate hydraulic conduc- } \\
\text { tivity; probably lacustrine depositional environment. }\end{array}$ \\
\hline $55.0-55.8$ & No recovery. \\
\hline $55.8-57.0$ & $\begin{array}{l}\text { Gastropod lime floatstone with quartz-sand-rich lime packstone matrix, pale-yellowish-brown } 10 \mathrm{YR} 6 / 2 \text {; clay to medium } \\
\text { grain size; gastropods, } 20 \text { to } 40 \text { percent fine to medium quartz sand; } 20 \text { percent moldic porosity; moderate hydraulic conduc- } \\
\text { tivity; probably lacustrine depositional environment. }\end{array}$ \\
\hline $57.0-59.0$ & $\begin{array}{l}\text { Skeletal fragment lime floatstone with quartz-sand-rich lime packstone and skeletal, quartz-sand-rich packstone; very pale } \\
\text { orange } 10 \mathrm{YR} 8 / 2 \text { to very light gray N8; clay to medium grain size, ranges from clay to pebble; gastropods, mollusks, miliol- } \\
\text { ids and peneroplids; } 20 \text { to } 40 \text { percent very fine to medium quartz sand; } 20 \text { percent moldic and vuggy porosity; moderate } \\
\text { hydraulic conductivity. }\end{array}$ \\
\hline $59.0-60.0$ & $\begin{array}{l}\text { Mollusk, skeletal lime floatstone with skeletal fragment quartz sandstone matrix; clay to medium grain size ranges from clay } \\
\text { to pebble; miliolids, mollusks and peneroplids, } 40 \text { percent very fine to medium quartz grains; quartz sandstone contains a } \\
\text { lime mud matrix; } 20 \text { percent vuggy and moldic porosity with solution channels; moderate hydraulic conductivity; truncated } \\
\text { root molds at top of interval and root molds with laminated calcrete linings (grayish orange 10YR } 7 / 4 \text { ) throughout interval, } \\
\text { probable exposure surface at top of interval }\end{array}$ \\
\hline $60.0-60.5$ & No recovery. \\
\hline $60.5-62.5$ & $\begin{array}{l}\text { Skeletal fragment, quartz sandstone with lime mud matrix, very pale orange } 10 \mathrm{YR} 8 / 2 \text { to grayish orange 10YR } 7 / 4 \text { to very } \\
\text { light gray N8; clay and fine to medium; ranges from clay to granule; mollusks and miliolids, } 20 \text { to } 40 \text { percent fine to medium } \\
\text { quartz grains; } 20 \text { percent moldic and vuggy porosity with minor solution channels; moderate hydraulic conductivity; interval } \\
\text { riddled with root molds lined with laminated calcrete. }\end{array}$ \\
\hline $62.5-63.0$ & $\begin{array}{l}\text { Skeletal lime grainstone, very light gray N8 and grayish orange } 10 \mathrm{YR} 7 / 4 \text {; fine grain size, ranges from very fine to pebble; } \\
\text { miliolids and peneroplids, } 10 \text { percent very fine quartz sand; } 10 \text { percent interparticle porosity; low hydraulic conductivity. }\end{array}$ \\
\hline $63.0-70.5$ & No recovery. \\
\hline $70.5-71.4$ & $\begin{array}{l}\text { Mollusk skeletal lime floatstone with skeletal lime grainstone matrix, very pale orange } 10 \mathrm{YR} 8 / 2 \text {; very fine to medium and } \\
\text { pebble grain size, ranges from very fine to pebble; stick-like Porites corals and dasyclad algae, } 40 \text { percent very fine to } \\
\text { medium quartz sand; } 30 \text { percent interparticle, moldic and large vuggy porosity with solution channels; high hydraulic con- } \\
\text { ductivity }\end{array}$ \\
\hline $71.4-72.5$ & $\begin{array}{l}\text { Skeletal fragment lime grainstone, very pale orange } 10 \mathrm{YR} 8 / 2 \text {; fine to medium grain size, ranges from very fine to granule; } \\
\text { peneroplids, } 10 \text { percent fine quartz sand; } 20 \text { percent interparticle porosity with minor solution channels; moderate hydraulic } \\
\text { conductivity. }\end{array}$ \\
\hline
\end{tabular}




\begin{tabular}{|c|c|}
\hline $\begin{array}{l}\text { Depth } \\
\text { (feet below } \\
\text { land } \\
\text { surface) }\end{array}$ & Lithologic description \\
\hline $72.5 \cdot 75.4$ & No recovery. \\
\hline $75.4-762$ & $\begin{array}{l}\text { Skeletal fragment lime grainstone, very pale orange } 10 \mathrm{YR} 8 / 2 \text {; fine to medium grain size, ranges from very fine to granule; } \\
\text { peneroplids, } 10 \text { percent fine quartz sand; } 20 \text { percent interparticle porosity with minor solution channels; moderate hydraulic } \\
\text { conductivity. }\end{array}$ \\
\hline $76.2-77.0$ & $\begin{array}{l}\text { Skeletal fragment lime floatstone with quartz-sand-rich, skeletal lime grainstone matrix, very pale orange } 10 \mathrm{YR} 8 / 2 \text { and } \\
\text { very light gray N8; very fine to medium and pebble grain size, ranges from very fine to pebble; mollusks, dasyclad algae and } \\
\text { peneroplids, } 10 \text { to } 40 \text { percent very fine to fine quartz sand; } 30 \text { percent interparticle porosity with solution channels; high } \\
\text { hydraulic conductivity. }\end{array}$ \\
\hline $77.0-79.5$ & $\begin{array}{l}\text { Skeletal fragment lime floatstone with quartz-sand-rich, skeletal lime grainstone matrix, very pale orange } 10 \mathrm{YR} 8 / 2 \text { and } \\
\text { very light gray N8; very fine to medium and pebble grain size, ranges from very fine to pebble; mollusks, dasyclad algae and } \\
\text { peneroplids, } 10 \text { to } 40 \text { percent very fine to fine quartz sand; } 20 \text { percent moldic and interparticle porosity; moderate hydraulic } \\
\text { conductivity. }\end{array}$ \\
\hline $79.5-80.5$ & No recovery. \\
\hline $80.5-81.0$ & $\begin{array}{l}\text { Rubble of skeletal fragment lime floatstone with quartz-sand-rich, skeletal lime grainstone matrix, very pale orange } 10 \mathrm{YR} \\
8 / 2 \text { and very light gray N8; very fine to medium and pebble grain size, ranges from very fine to pebble; mollusks, dasyclad } \\
\text { algae and peneroplids, } 10 \text { to } 40 \text { percent very fine to fine quartz sand; } 20 \text { percent moldic and interparticle porosity; moderate } \\
\text { hydraulic conductivity. }\end{array}$ \\
\hline $81.0-83.8$ & $\begin{array}{l}\text { Skeletal lime rudstone with quartz-sand-rich, skeletal lime grainstone, very pale orange } 10 \mathrm{YR} 8 / 2 \text {; very fine to pebble grain } \\
\text { size, ranges from very fine to pebble; mollusks and echinoids, } 10 \text { to } 40 \text { percent very fine to fine quartz sand; } 20 \text { percent mol- } \\
\text { dic and interparticle porosity; moderate hydraulic conductivity. }\end{array}$ \\
\hline $83.8-86.0$ & No recovery. \\
\hline $86.0-86.2$ & $\begin{array}{l}\text { Skeletal lime floatstone with quartz-sand-rich, lime packstone, pale-yellowish-brown } 10 \mathrm{YR} 6 / 2 \text {; clay to medium grain size, } \\
\text { ranges from clay to pebble; mollusks and echinoids, } 20 \text { percent very fine to fine quartz sand; } 20 \text { percent moldic and interpar- } \\
\text { ticle porosity; moderate hydraulic conductivity; root molds lined with laminated calcrete, exposure surface near or at top of } \\
\text { interval at } 86 \text { feet. }\end{array}$ \\
\hline $86.2-86.6$ & $\begin{array}{l}\text { Skeletal quartz-sand-rich lime wackestone, pale-yellowish-brown 10YR } 6 / 2 \text {; clay to very fine, ranges from clay to coarse; } 1 \\
\text { percent very fine to fine quartz sand; } 10 \text { percent fenestral(?) porosity; low hydraulic conductivity; root molds lined with lam- } \\
\text { inated calcrete. }\end{array}$ \\
\hline $86.6-87.3$ & $\begin{array}{l}\text { Mollusk lime floatstone with quartz-sand-rich, skeletal lime packstone matrix, very pale orange } 10 \mathrm{YR} 8 / 2 \text {; clay to pebble } \\
\text { grain size; mollusks, miliolids, } 40 \text { percent very fine to fine quartz sand; } 15 \text { percent moldic and root mold porosity; low } \\
\text { hydraulic conductivity; root molds lined with laminated calcrete. }\end{array}$ \\
\hline $87.3-88.0$ & $\begin{array}{l}\text { Mollusk lime floatstone with quartz-sand-rich, skeletal lime packstone matrix, very pale orange } 10 \mathrm{YR} 8 / 2 \text {; clay to pebble } \\
\text { grain size; mollusks, miliolids, } 40 \text { percent very fine to fine quartz sand; } 20 \text { percent moldic and root mold porosity; inoderate } \\
\text { hydraulic conductivity; root molds lined with laminated calcrete. }\end{array}$ \\
\hline $88.0-90.5$ & No recovery. \\
\hline $90.5-90.9$ & $\begin{array}{l}\text { Skeletal lime grainstone, very pale orange } 10 \mathrm{YR} 8 / 2 \text {; very fine to fine, ranges from very fine to coarse; mollusks and miliol- } \\
\text { ids; } 10 \text { percent moldic porosity; low hydraulic conductivity, }\end{array}$ \\
\hline $90.9-91.6$ & $\begin{array}{l}\text { Skeletal lime floatstone with quartz-sand-rich lime packstone matrix, very pale orange } 10 \mathrm{YR} 8 / 2 \text {; clay to coarse, ranges } \\
\text { from clay to pebble; mollusks, } 20 \text { to } 40 \text { percent very fine to fine quartz sand, } 15 \text { percent moldic porosity with solution chan- } \\
\text { nels; moderate hydraulic conductivity. }\end{array}$ \\
\hline $91.6-94.0$ & $\begin{array}{l}\text { Mollusk lime floatstone with quartz-sand-rich, skeletal fragment lime packstone and grainstone, very pale orange } 10 \text { YR } 8 / 2 \\
\text { to very light gray N8; clay to fine grain size, ranges from clay to pebble; mollusks, gastropods, miliolids and peneroplids, } 40 \\
\text { percent very fine to medium quartz sand; } 20 \text { percent moldic and vuggy solution channels with minor solution channels; high } \\
\text { hydraulic conductivity. }\end{array}$ \\
\hline $94.0-95.4$ & $\begin{array}{l}\text { Skeletal lime floatstone and rudstone with skeletal, quartz-sand-rich lime packstone, very pale orange } 10 \mathrm{YR} 8 / 2 \text { to very light } \\
\text { gray N8; clay to pebble grain size, ranges from clay to pebble; mollusks, } 10 \text { percent fine to medium quartz sand; } 25 \text { percent } \\
\text { vuggy and moldic porosity; moderate hydraulic conductivity }\end{array}$ \\
\hline $95.4-96.0$ & $\begin{array}{l}\text { Rubble of skeletal fragment, quartz-sand-rich lime grainstone, very pale orange } 10 \mathrm{YR} 8 / 2 \text { to very light gray } \mathrm{N} 8 \text {; very fine to } \\
\text { medium grain size, ranges from very fine to medium; } 10 \text { percent very fine quartz sand; } 10 \text { percent interparticle porosity; low } \\
\text { hydraulic conductivity. }\end{array}$ \\
\hline $96.0-100.5$ & $\begin{array}{l}\text { Molluscan lime floatstone and rudstone with quartz-sand-rich, skeletal lime packstone, very pale orange } 10 \text { YR } 8 / 2 \text { to very } \\
\text { light gray N8; clay to pebble grain size; ranges from clay to pebble; mollusks and gastropods, } 10 \text { to } 30 \text { percent very fine to } \\
\text { medium quartz sand; } 20 \text { percent moldic and vuggy porosity; moderate hydraulic conductivity. }\end{array}$ \\
\hline
\end{tabular}




\section{Peacock Park}

\begin{tabular}{|c|c|}
\hline $\begin{array}{l}\text { Depth } \\
\text { (feet below } \\
\text { land } \\
\text { surface) }\end{array}$ & Lithologic description \\
\hline $0.0-1.0$ & $\begin{array}{l}\text { Quartz-sand-rich soil, dark-yellowish-brown } 10 \mathrm{YR} 4 / 2 ; \text { mainly clay and fine to medium grain size, ranges from clay to } \\
\text { coarse; roots; } 20 \text { percent interparticle porosity; low hydraulic conductivity. }\end{array}$ \\
\hline $1.0-2.0$ & $\begin{array}{l}\text { Rubble of oolitic lime grainstone, very pale orange } 10 \mathrm{YR} 8 / 2 \text {; mainly medium grain size; } 25 \text { percent oomoldic and probable } \\
\text { solution-channel porosity; high hydraulic conductivity. }\end{array}$ \\
\hline $2.0-3.0$ & $\begin{array}{l}\text { Loose quartz sand, very pale orange } 10 \mathrm{YR} 8 / 2 \text {, grayish orange } 10 \mathrm{YR} 7 / 4 \text {; mainly fine to medium, ranges from fine to } \\
\text { medium; } 25 \text { percent interparticle porosity; moderate hydraulic conductivity; bay sediments(?). }\end{array}$ \\
\hline $3.0-4.0$ & No recovery. \\
\hline $4.0-5.0$ & $\begin{array}{l}\text { Silty mudstone, very pale orange } 10 \mathrm{YR} 8 / 2 \text {, pale-yellowish-brown } 10 \mathrm{YR} 6 / 2 \text {, brownish gray } 5 \mathrm{YR} 4 / 1 \text {; mainly clay to silt; } \\
\text { roots; } 5 \text { percent interparticle porosity; very low hydraulic conductivity; bay sediments(?) }\end{array}$ \\
\hline $5.0-5.5$ & $\begin{array}{l}\text { Peat; black NI; mainly clay to silt; roots; } 25 \text { percent interparticle porosity; very low hydraulic conductivity; bay sedi- } \\
\text { ments(?) }\end{array}$ \\
\hline $5.5-8.5$ & $\begin{array}{l}\text { Loose quartz sand, pale-yellowish-brown } 10 \mathrm{YR} 6 / 2 \text {, light gray N7; mainly fine to medium grain size, ranges from very fine } \\
\text { to coarse; caved grains; } 25 \text { percent interparticle porosity; moderate hydraulic conductivity; mainly caved quartz sand (?) }\end{array}$ \\
\hline $8.5-9.0$ & $\begin{array}{l}\text { Calcretized oolitic lime grainstone, very pale orange } 10 \mathrm{YR} 8 / 2 \text {, pale-yellowish-brown } 10 \mathrm{YR} 6 / 2 \text {; medium grain size; } 25 \text { per- } \\
\text { cent oomoldic and solution-channel porosity; high hydraulic conductivity. }\end{array}$ \\
\hline $9.0-11.0$ & No recovery. \\
\hline $11.0-13.0$ & $\begin{array}{l}\text { Loose quartz sand, very light gray } \mathrm{N} 7 \text { mainly fine to medium grain size, ranges from fine to coarse; caved particles and } \\
\text { roots; } 25 \text { percent interparticle porosity; moderate hydraulic conductivity. }\end{array}$ \\
\hline $13.0-13.8$ & $\begin{array}{l}\text { Rubble of oolitic lime grainstone, very pale orange } 10 \mathrm{YR} 8 / 2 \text {; mainly fine grain size; ranges from fine to pebble; mollusks } \\
\text { and branching bryozoans } 25 \text { percent oomoldic and solution-channel porosity; high hydraulic conductivity. }\end{array}$ \\
\hline $13.8-15.0$ & $\begin{array}{l}\text { Rubble of oolitic lime grainstone, very pale orange } 10 \mathrm{YR} 8 / 2 \text {, grayish orange } 10 \mathrm{YR} 7 / 4 \text {, moderate yellowish brown } 10 \mathrm{YR} \\
5 / 4 \text {; mainly fine grain size; ranges from fine to pebble; mollusks and branching bryozoans } 25 \text { percent oomoldic and solution- } \\
\text { channel porosity; high hydraulic conductivity. }\end{array}$ \\
\hline $15.0-16.0$ & $\begin{array}{l}\text { Loose quartz sand, very light gray } \mathrm{N} 7 \text {; mainly fine to medium grain size, ranges from fine to coarse; } 25 \text { percent interparticle } \\
\text { porosity; moderate hydraulic conductivity. }\end{array}$ \\
\hline $16.0-18.0$ & $\begin{array}{l}\text { Rubble of oolitic lime grainstone, very pale orange } 10 \mathrm{YR} 8 / 2 \text {, grayish orange } 10 \mathrm{YR} 7 / 4 \text {, moderate yellowish brown } 10 \mathrm{YR} \\
5 / 4 \text {; mainly fine grain size, ranges from fine to medium; } 25 \text { percent oomoldic and solution-channel porosity; high hydraulic } \\
\text { conductivity. }\end{array}$ \\
\hline $18.0-23.2$ & No recovery. \\
\hline $23.2-24.0$ & $\begin{array}{l}\text { Rubble of sandstone cemented with calcite and oolitic lime grainstone, sample is probably cave, very pale orange } 10 \mathrm{YR} \\
8 / 2 \text {, grayish orange } 10 \mathrm{YR} 7 / 4 \text {, moderate yellowish brown } 10 \mathrm{YR} 5 / 4 \text {; mainly fine grain size, ranges from fine to medium; } 25 \\
\text { percent oomoldic, interparticle and vuggy porosity; high hydraulic conductivity. }\end{array}$ \\
\hline $24.0-25.0$ & No recovery. \\
\hline $25.0-25.5$ & $\begin{array}{l}\text { Rubble of oolitic lime grainstone, very pale orange } 10 \mathrm{YR} 8 / 2 \text {, grayish orange } 10 \mathrm{YR} 7 / 4 \text {; mainly fine grain size, ranges from } \\
\text { fine to pebble; branching bryozoans and mollusks; } 25 \text { percent oomoldic porosity; high hydraulic conductivity. }\end{array}$ \\
\hline $25.5-30.0$ & No recovery. \\
\hline $30.0-30.8$ & $\begin{array}{l}\text { Skeletal-fragment lime grainstone, very pale orange } 10 \mathrm{YR} 8 / 2 \text {, grayish orange } 10 \mathrm{YR} 7 / 4 \text {, dark-yellowish-orange } 10 \mathrm{YR} 6 / 6 \text {; } \\
\text { mainly fine to medium grain size, ranges from very fine to granule; } 35 \text { percent vuggy, moldic, interparticle and solution- } \\
\text { channel porosity; very high hydraulic conductivity; probable exposure surface between } 25.5 \text { and } 30 \text { feet. }\end{array}$ \\
\hline $30.8-31.7$ & $\begin{array}{l}\text { Skeletal-fragment lime rudstone with skeletal-fragment lime grainstone matrix; very pale orange } 10 \mathrm{YR} 8 / 2 \text {, grayish-orange } \\
10 \mathrm{YR} 7 / 4 \text {, dark-yellowish-orange } 10 \mathrm{YR} 6 / 6 \text {; mainly fine to granule grain size; } 35 \text { percent vuggy, moldic, interparticle and } \\
\text { solution-channel porosity; very high hydraulic conductivity. }\end{array}$ \\
\hline $31.7-32.7$ & $\begin{array}{l}\text { Skeletal-fragment lime rudstone with skeletal-fragment lime grainstone matrix; very pale orange } 10 \mathrm{YR} 8 / 2 \text {, grayish-orange } \\
10 \mathrm{YR} 7 / 4 \text {, dark-yellowish-orange } 10 \mathrm{YR} 6 / 6 \text {; mainly medium to pebble grain size; } 35 \text { percent vuggy, moldic, interparticle } \\
\text { and solution-channel porosity; very high hydraulic conductivity. }\end{array}$ \\
\hline $32.7-34.0$ & $\begin{array}{l}\text { Monastrea lime framestone, very pale orange } 10 \mathrm{YR} 8 / 2 ; \text { mainly cobble grain size; } 25 \text { percent intraparticle porosity; very } \\
\text { high hydraulic conductivity. }\end{array}$ \\
\hline $34.0-35.0$ & No recovery. \\
\hline $35.0-36.0$ & $\begin{array}{l}\text { Rubble of coral lime framestone, very pale orange } 10 \mathrm{YR} 8 / 2 \text {; mainly clay and pebble and cobble, ranges from clay to cob- } \\
\text { ble; } 25 \text { percent intraparticle porosity; very high hydraulic conductivity. }\end{array}$ \\
\hline
\end{tabular}




\begin{tabular}{|c|c|}
\hline $\begin{array}{l}\text { Depth } \\
\text { (feet below } \\
\text { land } \\
\text { surface) }\end{array}$ & Lithologic description \\
\hline $36.0-40.8$ & No recovery. \\
\hline $40.8-41.8$ & $\begin{array}{l}\text { Rubble of skeletal lime packstone, very pale orange } 10 \mathrm{YR} 8 / 2 \text {, grayish orange } 10 \mathrm{YR} 7 / 4 \text {; mainly clay to pebble; ranges from } \\
\text { clay to pebble; } 20 \text { percent moldic and vuggy porosity; high hydraulic conductivity; possible cave. }\end{array}$ \\
\hline $41.8-43.0$ & $\begin{array}{l}\text { Friable calcareous quartz sandstone; very pale orange } 10 \mathrm{YR} 8 / 2 \text {, pale-yellowish-orange } 10 \mathrm{YR} 6 / 6 \text {; grayish-orange } 10 \mathrm{YR} \\
7 / 4 \text {; mainly very fine to fine grain size, ranges from very fine to medium; } 20 \text { percent interparticle porosity; moderate hydrau- } \\
\text { lic conductivity. }\end{array}$ \\
\hline $43.0-45.5$ & $\begin{array}{l}\text { Rubble of skeletal lime grainstone and packstone and oolitic lime grainstone, very pale orange } 10 \mathrm{YR} 8 / 2 \text {, grayish-orange } \\
10 \mathrm{YR} 7 / 4 \text {; mainly clay to pebble grain size, ranges from clay to pebble; } 20 \text { percent moldic, vuggy and interparticle porosity. } \\
\text { high hydraulic conductivity; at least some of the rubbly limestone is cave (oolitic lime grainstone) }\end{array}$ \\
\hline $45.5-51.0$ & No recovery. \\
\hline $51.0-51.5$ & Rubble of caved limestone. \\
\hline $51.5-52.0$ & $\begin{array}{l}\text { Diplora coral lime framestone, very pale orange } 10 \mathrm{YR} 8 / 2 ; \text { mainly cobble grain size; } 30 \text { percent intraparticle porosity; very } \\
\text { high hydraulic conductivity. }\end{array}$ \\
\hline $52.0-61.0$ & Rubble of caved limestone. \\
\hline $61.0-62.5$ & $\begin{array}{l}\text { Skeletal fragment lime wackestone, packstone and grainstone, mottled combination of very pale orange } 10 \mathrm{YR} 8 / 2 \text {, pale-yel- } \\
\text { lowish-orange } 10 \mathrm{YR} 8 / 6 \text {, grayish orange } 10 \mathrm{YR} 7 / 4 \text {, and very light gray } \mathrm{N} 7 \text {; mainly clay to medium grain size; ranges from } \\
\text { clay to pebble; peloids, mollusks, gastropods and echinoid spines; } 25 \text { percent moldic, root-mold and minor solution-channel } \\
\text { porosity; high hydraulic conductivity; mottled colors, root molds and solution channels suggest exposure surface between } 52 \\
\text { and } 61 \text { feet. }\end{array}$ \\
\hline $62.5-71.0$ & No recovery. \\
\hline $71.0-71.5$ & $\begin{array}{l}\text { Rubble of skeletal fragment lime wackestone, packstone and grainstone, mottled combination of very pale orange } 10 \mathrm{YR} 8 / 2 \text {, } \\
\text { pale-yellowish-orange } 10 \mathrm{YR} 8 / 6 \text {, grayish orange } 10 \mathrm{YR} 7 / 4 \text {, and very light gray N7; mainly clay to medium grain size; } \\
\text { ranges from clay to pebble; peloids, mollusks, gastropods and echinoid spines; } 25 \text { percent moldic, root-mold and minor solu- } \\
\text { tion-channel porosity; high hydraulic conductivity. }\end{array}$ \\
\hline $71.5-72.0$ & $\begin{array}{l}\text { Skeletal fragment lime wackestone and packstone, mottled combination of very pale orange } 10 \mathrm{YR} 8 / 2 \text {, pale-yellowish- } \\
\text { orange } 10 \mathrm{YR} 8 / 6 \text {, grayish orange } 10 \mathrm{YR} 7 / 4 \text {, and very light gray } \mathrm{N} 7 \text {; mainly clay to medium grain size; ranges from clay to } \\
\text { pebble; peloids, mollusks, miliolids and gastropods; } 25 \text { percent moldic, root-mold and minor solution-channel porosity; high } \\
\text { hydraulic conductivity. }\end{array}$ \\
\hline $72.0-73.0$ & $\begin{array}{l}\text { Red algae, skeletal fragment, quartz-sand-rich lime grainstone; very pale orange } 10 \mathrm{YR} 8 / 2 \text {; light gray N8; mainly very fine } \\
\text { to coarse grain size. ranges from very fine to pebble; } 10 \text { percent fine to medium quartz sand; red algae and mollusks; } 20 \text { per- } \\
\text { cent moldic and interparticle porosity; moderate hydraulic conductivity. }\end{array}$ \\
\hline $73.0-76.2$ & No recovery. \\
\hline $76.2-77.6$ & $\begin{array}{l}\text { Skeletal fragment, red algae, quartz-sand-rich lime grainstone; very light gray N7; light gray N8; mainly very fine to coarse } \\
\text { grain size. ranges from very fine to pebble; } 20 \text { percent fine to medium quartz sand; mollusks; } 15 \text { percent moldic and interpar- } \\
\text { ticle porosity; moderate hydraulic conductivity. }\end{array}$ \\
\hline $77.6-78.0$ & $\begin{array}{l}\text { Red algae lime floatstone with quartz-sand-rich, skeletal lime packstone matrix, mollusks, very pale orange } 10 \text { YR } 8 / 2 \text {, light } \\
\text { gray N7; mainly clay to granule, ranges from clay to pebble; } 20 \text { percent fine to medium quartz sand, mollusks; } 15 \text { percent } \\
\text { moldic, intergranular and vuggy porosity; moderate hydraulic conductivity. }\end{array}$ \\
\hline $78.0-81.0$ & No recovery. \\
\hline $81.0-82.3$ & $\begin{array}{l}\text { Red algae, mollusk lime rudstone and floatstone with quartz-sand-rich, skeletal lime packstone matrix, light gray N7, very } \\
\text { pale orange } 10 \mathrm{YR} 8 / 2 \text {, grayish orange } 10 \mathrm{YR} 7 / 4 \text {; mainly clay to pebble grain size, ranges from clay to pebble; } 20 \text { percent } \\
\text { fine to medium quartz sand and minor coarse quartz sand; } 15 \text { percent moldic and vuggy porosity; moderate hydraulic con- } \\
\text { ductivity. }\end{array}$ \\
\hline $82.3-83.5$ & $\begin{array}{l}\text { Skeletal fragment, quartz-sand-rich lime grainstone, yellowish gray } 5 \mathrm{Y} 8 / 1 \text {; mainly fine to medium grain size, ranges from } \\
\text { very fine to medium; } 15 \text { to } 25 \text { percent very fine to fine quartz sand; mollusks, gastropods; } 25 \text { percent moldic and interparti- } \\
\text { cle porosity; moderate hydraulic conductivity. }\end{array}$ \\
\hline $83.5-84.9$ & $\begin{array}{l}\text { Lime mudstone, wackestone and packstone; very pale orange } 10 \mathrm{YR} 8 / 2 \text {; mainly clay to very fine grain size, } 10 \text { percent very } \\
\text { fine to fine quartz sand gastropods, mollusks; } 15 \text { percent moldic and root-mold porosity; low hydraulic conductivity; } \\
\text { supratidal or intertidal environment, root molds, subaerial exposure surface at } 83.5 \text { feet. }\end{array}$ \\
\hline $84.9-85.2$ & $\begin{array}{l}\text { Skeletal, quartz-sand-rich lime packstone; very pale orange } 10 \mathrm{YR} 8 / 2 \text {; mainly clay to medium grain size; } 20 \text { percent very } \\
\text { fine to fine quartz sand; } 15 \text { percent moldic porosity; moderate hydraulic conductivity. }\end{array}$ \\
\hline $85.2-88.0$ & No recovery. \\
\hline
\end{tabular}




\section{Depth \\ (feet below \\ land}

Lithologic description

surface)

Skeletal, quartz-sand-rich lime grainstone, very light gray N7, very pale orange 10YR 8/2; mainly very fine to medium grain

88.0 - 89.0 size, ranges from very fine to coarse; 20 percent very fine to fine quartz sand, gastropods, mollusks; 20 percent moldic and interparticle porosity; moderate hydraulic conductivity.

Mollusk lime rudstone with quartz sand-rich, skeletal lime packstone matrix, very light gray N7, very pale orange $10 \mathrm{YR} 8 / 2$
mainly clay to fine and pebble grain size, ranges from clay to pebble; 20 percent very fine to fine quartz sand; 15 percent moldic porosity; moderate hydraulic conductivity.

Skeletal, mollusk, quartz-sand-rich lime packstone and grainstone and minor lime floatstone with skeletal, quartz-sand-rich matrix; very light gray N7, very pale orange $10 \mathrm{YR} 8 / 2$; mainly clay to medium grain size; ranges from clay to pebble; 30

$89.5-91.0$ percent very fine to fine quartz sand, mollusks, red algae; 15 percent moldic and interparticle porosity; moderate hydraulic conductivity.

\begin{tabular}{|c|c|}
\hline $91.0-95.0$ & No recovery. \\
\hline $95.0-95.5$ & Rubble of caved limestone. \\
\hline $95.5-100.0$ & $\begin{array}{l}\text { Skeletal fragment, quartz-sand-rich lime grainstone and minor lime packstone, very light gray N7, very pale orange } 10 \mathrm{YR} \\
8 / 2 \text {; mainly very fine to medium grain size, ranges from clay to pebble; } 10 \text { to } 20 \text { percent very fine to fine quartz sand and } \\
\text { minor medium quartz sand, mollusks, gastropods, miliolids; } 20 \text { percent moldic, interparticle and vuggy porosity; moderate } \\
\text { hydraulic conductivity. }\end{array}$ \\
\hline
\end{tabular}

$100.0-101.0 \quad$ No recovery. 


\section{Appendix II. Field Data Collected as Part of this Study}

$[--$, not reported (time) or not measured]

\begin{tabular}{|c|c|c|c|c|c|c|}
\hline $\begin{array}{l}\text { Well } \\
\text { name }\end{array}$ & Transect & Date & Time & $\begin{array}{l}\text { Fluid } \\
\text { conductivity } \\
\text { (microsiemens } \\
\text { per centimeter) }\end{array}$ & $\begin{array}{c}\text { Chloride } \\
\text { concentra- } \\
\text { tion } \\
\text { (milligrams } \\
\text { per liter) }\end{array}$ & $\begin{array}{l}\text { Depth to } \\
\text { water } \\
\text { (feet) }\end{array}$ \\
\hline G-906 & Deering Estate & $03-02-98$ & 1700 & 50,200 & 18,600 & 8.68 \\
\hline G-906 & Deering Estate & 04-03-98 & 1305 & 49,700 & 19,100 & 9.10 \\
\hline G-906 & Deering Estate & $05-04-98$ & 1115 & 49,800 & 19,100 & 9.32 \\
\hline G-906 & Deering Estate & $06-01-98$ & 1110 & 48,700 & -- & 8.83 \\
\hline G-906 & Deering Estate & $07-06-98$ & 1139 & 47,900 & -- & 8.86 \\
\hline G-906 & Deering Estate & $08-06-98$ & 0902 & 49,400 & -- & 8.60 \\
\hline G-906 & Deering Estate & $09-03-98$ & 0907 & 45,200 & -- & 8.32 \\
\hline G-906 & Deering Estate & $10-06-98$ & 0827 & 50,100 & -- & 8.42 \\
\hline G-906 & Deering Estate & $11-18-98$ & 0911 & 50,300 & -- & 8.40 \\
\hline G-906 & Deering Estate & $12-18-98$ & 1342 & - & -- & 8.69 \\
\hline G-906 & Deering Estate & $02-11-99$ & 1238 & 50,000 & -- & 8.89 \\
\hline G-906 & Deering Estate & 03-03-99 & 1000 & -- & -- & 8.28 \\
\hline G-911 & Deering Estate & $04-03-98$ & 1308 & 4,920 & -- & 9.45 \\
\hline G-911 & Deering Estate & $05-04-98$ & 1117 & 6,080 & 1,800 & 9.68 \\
\hline G-911 & Deering Estate & $06-01-98$ & 1216 & -- & -- & 9.10 \\
\hline G-911 & Deering Estate & $07-06-98$ & 1207 & 6,460 & -- & 9.28 \\
\hline G-911 & Deering Estate & $08-06-98$ & 0948 & 6,510 & -- & 9.04 \\
\hline G-911 & Deering Estate & $09-03-98$ & 0903 & 7,750 & -- & 8.70 \\
\hline G-911 & Deering Estate & $10-06-98$ & 0824 & 8,500 & -- & 8.85 \\
\hline G-911 & Deering Estate & $11-18-98$ & 0905 & 8,340 & -- & 8.88 \\
\hline G-911 & Deering Estate & $02-11-99$ & 1301 & 5,680 & -- & 9.24 \\
\hline G-911 & Deering Estate & 03-03-99 & 1003 & -- & -- & 8.64 \\
\hline G-912 & Deering Estate & $03-02-98$ & 1710 & 970 & 145 & 8.57 \\
\hline G-912 & Deering Estate & $04-03-98$ & 1311 & 979 & 150 & 8.93 \\
\hline G-912 & Deering Estate & $05-04-98$ & 1120 & 1,024 & 160 & 9.16 \\
\hline G-912 & Deering Estate & $06-01-98$ & 1152 & 1,124 & -- & 8.60 \\
\hline G-912 & Deering Estate & $07-06-98$ & 1203 & 942 & -- & 8.74 \\
\hline
\end{tabular}




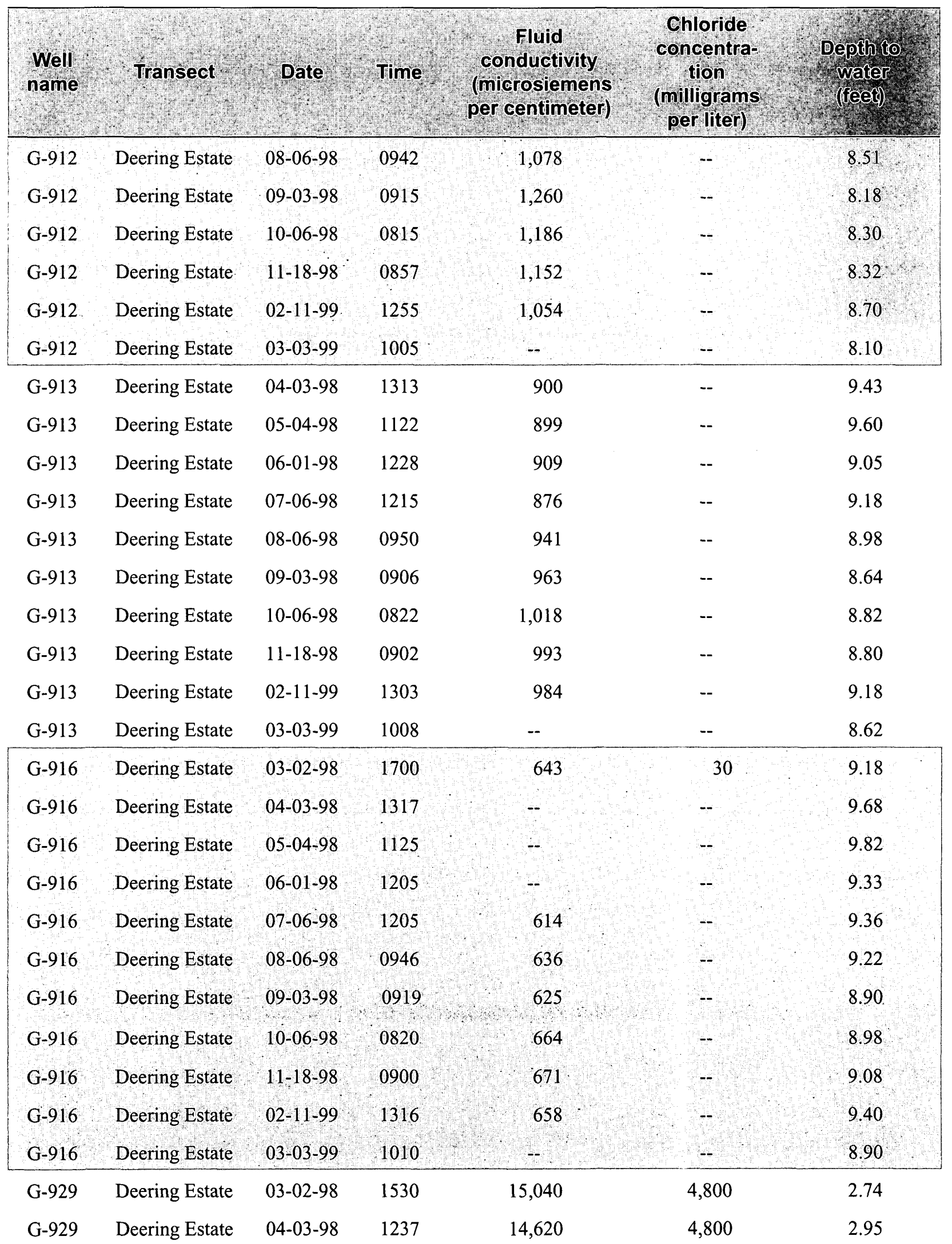




\begin{tabular}{|c|c|c|c|c|c|c|}
\hline $\begin{array}{c}\text { Well } \\
\text { name }\end{array}$ & Transect & Date & Time & $\begin{array}{c}\text { Fluid } \\
\text { conductivity } \\
\text { (microsiemens } \\
\text { per centimeter) }\end{array}$ & $\begin{array}{c}\text { Chloride } \\
\text { concentra- } \\
\text { tion } \\
\text { (milligrams } \\
\text { per liter) }\end{array}$ & $\begin{array}{c}\text { Depth to } \\
\text { water } \\
\text { (feet) }\end{array}$ \\
\hline G-929 & Deering Estate & $05-04-98$ & 1150 & 18,700 & 6,300 & 3.31 \\
\hline G-929 & Deering Estate & $06-01-98$ & 1305 & 21,300 & -- & 2.28 \\
\hline G-929 & Deering Estate & $07-06-98$ & 0957 & 15,100 & -- & 2.68 \\
\hline G-929 & Deering Estate & 08-06-98 & 0745 & 20,000 & -- & 2.26 \\
\hline G-929 & Deering Estate & $09-03-98$ & 0753 & 20,800 & -- & 1.90 \\
\hline G-929 & Deering Estate & $10-06-98$ & 1024 & 17,100 & -- & 1.70 \\
\hline G-929 & Deering Estate & $11-17-98$ & 1522 & 16,600 & -- & 3.15 \\
\hline G-929 & Deering Estate & $02-11-99$ & 1133 & 15,200 & -- & 2.84 \\
\hline G-929 & Deering Estate & 03-03-99 & 0935 & -- & -- & 1.80 \\
\hline G-930 & Deering Estate & $03-02-98$ & 1530 & $2,5.87$ & 620 & 2.48 \\
\hline G-930 & Deering Estate & 04-03-98 & 1238 & 2,846 & 720 & 2.78 \\
\hline G-930 & Deering Estate & $05-04-98$ & 1151 & 2,750 & 700 & 3.16 \\
\hline G-930 & Deering Estate & $06-01-98$ & 1307 & 2,320 & -- & 2.11 \\
\hline G-930 & Deering Estate & $07-06-98$ & 1001 & 4,910 & -- & 2.53 \\
\hline G-930 & Deering Estate & $08-06-98$ & 0750 & 3,834 & -- & 2.06 \\
\hline G-930 & Deering Estate & 09-03-98 & 0756 & 2,950 & -- & 1.72 \\
\hline G-930 & Deering Estate & $10-06-98$ & 1025 & 10,920 & -- & 1.53 \\
\hline G-930 & Deering Estate & $11-17-98$ & 1525 & 4,500 & -- & 2.96 \\
\hline G-930 & Deering Estate & $02-11-99$ & 1136 & 4,530 & -- & 2.65 \\
\hline G-930 & Deering Estate & 03-03-99 & 0936 & -- & -- & 1.60 \\
\hline G-931 & Deering Estate & $03-02-98$ & 1555 & 1,280 & 235 & 2.51 \\
\hline G-931 & Deering Estate & 04-03-98 & 1240 & 1,344 & 250 & 2.79 \\
\hline G-931 & Deering Estate & $05-04-98$ & 1153 & 1,370 & 260 & 3.15 \\
\hline G-931 & Deering Estate & $06-01-98$ & 1317 & 1,278 & -- & 2.08 \\
\hline G-931 & Deering Estate & $07-06-98$ & 1007 & 1,230 & -- & 2.57 \\
\hline G-931 & Deering Estate & $08-06-98$ & 0754 & 1,247 & -- & 2.06 \\
\hline G-931 & Deering Estate & $09-03-98$ & 0757 & 1,280 & -- & 1.74 \\
\hline G-931 & Deering Estate & $10-06-98$ & 1026 & 1,307 & -- & 1.54 \\
\hline G-931 & Deering Estate & $11-17-98$ & 1518 & 1,293 & -- & 2.97 \\
\hline
\end{tabular}




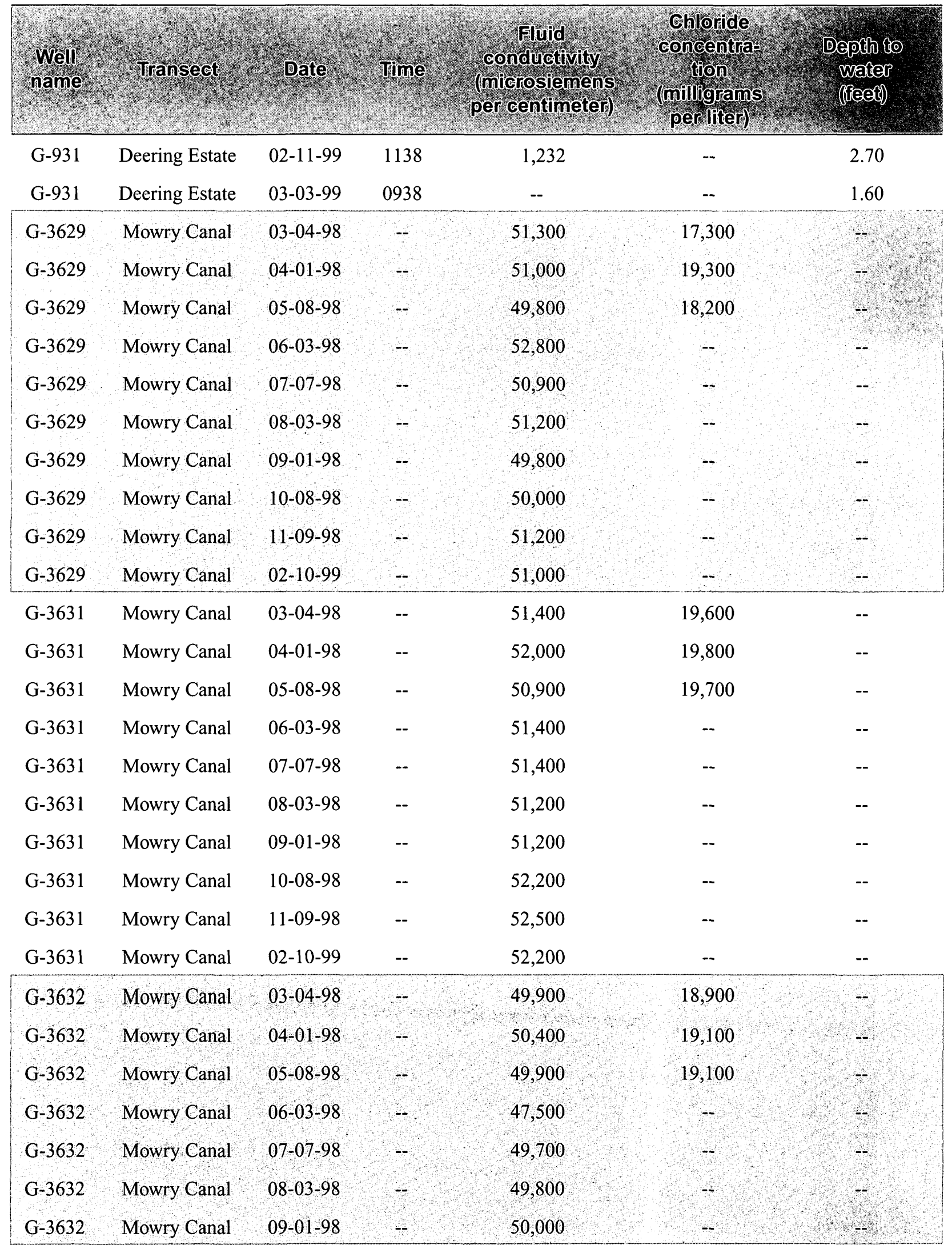




\begin{tabular}{|c|c|c|c|c|c|c|}
\hline $\begin{array}{c}\text { Well } \\
\text { name }\end{array}$ & Transect & Date & Time & $\begin{array}{c}\text { Fluid } \\
\text { conductivity } \\
\text { (microsiemens } \\
\text { per centimeter) }\end{array}$ & $\begin{array}{l}\text { Chloride } \\
\text { concentra- } \\
\text { tion } \\
\text { (milligrams } \\
\text { per liter) }\end{array}$ & $\begin{array}{l}\text { Depth to } \\
\text { water } \\
\text { (feet) }\end{array}$ \\
\hline G-3632 & Mowry Canal & $10-08-98$ & -- & 49,700 & -- & -- \\
\hline G-3632 & Mowry Canal & $11-09-98$ & -- & 48,100 & -- & -- \\
\hline G-3632 & Mowry Canal & $02-10-99$ & -- & 50,800 & -- & -- \\
\hline G-3634 & Mowry Canal & 03-04-98 & -- & 52,200 & 19,800 & -- \\
\hline G-3634 & Mowry Canal & $04-01-98$ & -- & 52,400 & 20,000 & -- \\
\hline G-3634 & Mowry Canal & $05-08-98$ & -- & 51,800 & 20,000 & -- \\
\hline G-3634 & Mowry Canal & $06-03-98$ & -- & 51,400 & -- & -- \\
\hline G-3634 & Mowry Canal & $07-07-98$ & -- & 51,800 & -- & -- \\
\hline G-3634 & Mowry Canal & $08-03-98$ & -- & 51,300 & -- & -- \\
\hline G-3634 & Mowry Canal & $09-01-98$ & -- & 51,700 & -- & -- \\
\hline G-3634 & Mowry Canal & $10-08-98$ & -- & 51,900 & -- & -- \\
\hline G-3634 & Mowry Canal & $11-09-98$ & -- & 51,200 & -- & -- \\
\hline G-3634 & Mowry Canal & $02-10-99$ & -- & 52,800 & -- & -- \\
\hline G-3635 & Mowry Canal & $03-04-98$ & -- & 49,000 & 18,500 & -- \\
\hline G-3635 & Mowry Canal & $04-01-98$ & -- & 49,000 & 18,400 & -- \\
\hline G-3635 & Mowry Canal & $05-08-98$ & - & 48,600 & 18,500 & -- \\
\hline G-3635 & Mowry Canal & $06-03-98$ & - & 48,600 & -- & -- \\
\hline G-3635 & Mowry Canal & $07-07-98$ & - & 49,100 & -- & -- \\
\hline G-3635 & Mowry Canal & $08-03-98$ & -- & 48,700 & -- & -- \\
\hline G-3635 & Mowry Canal & $09-01-98$ & -- & 49,200 & -- & -- \\
\hline G-3635 & Mowry Canal & $10-08-98$ & - & 49,100 & -- & -- \\
\hline G-3635 & Mowry Canal & $11-09-98$ & - & 46,300 & -- & -- \\
\hline G-3635 & Mowry Canal & $02-10-99$ & - & 48,800 & -- & -- \\
\hline G-3636 & Mowry Canal & $03-04-98$ & -- & 52,000 & 19,900 & -- \\
\hline G-3636 & Mowry Canal & $04-01-98$ & -- & 52,600 & 20,000 & -- \\
\hline G-3636 & Mowry Canal & $05-08-98$ & -- & 51,700 & 19,900 & -- \\
\hline G-3636 & Mowry Canal & $06-03-98$ & -- & 51,400 & -- & -- \\
\hline G-3636 & Mowry Canal & $07-07-98$ & -- & 51,900 & -- & -- \\
\hline G-3636 & Mowry Canal & $08-03-98$ & -- & 51,900 & -- & -- \\
\hline
\end{tabular}




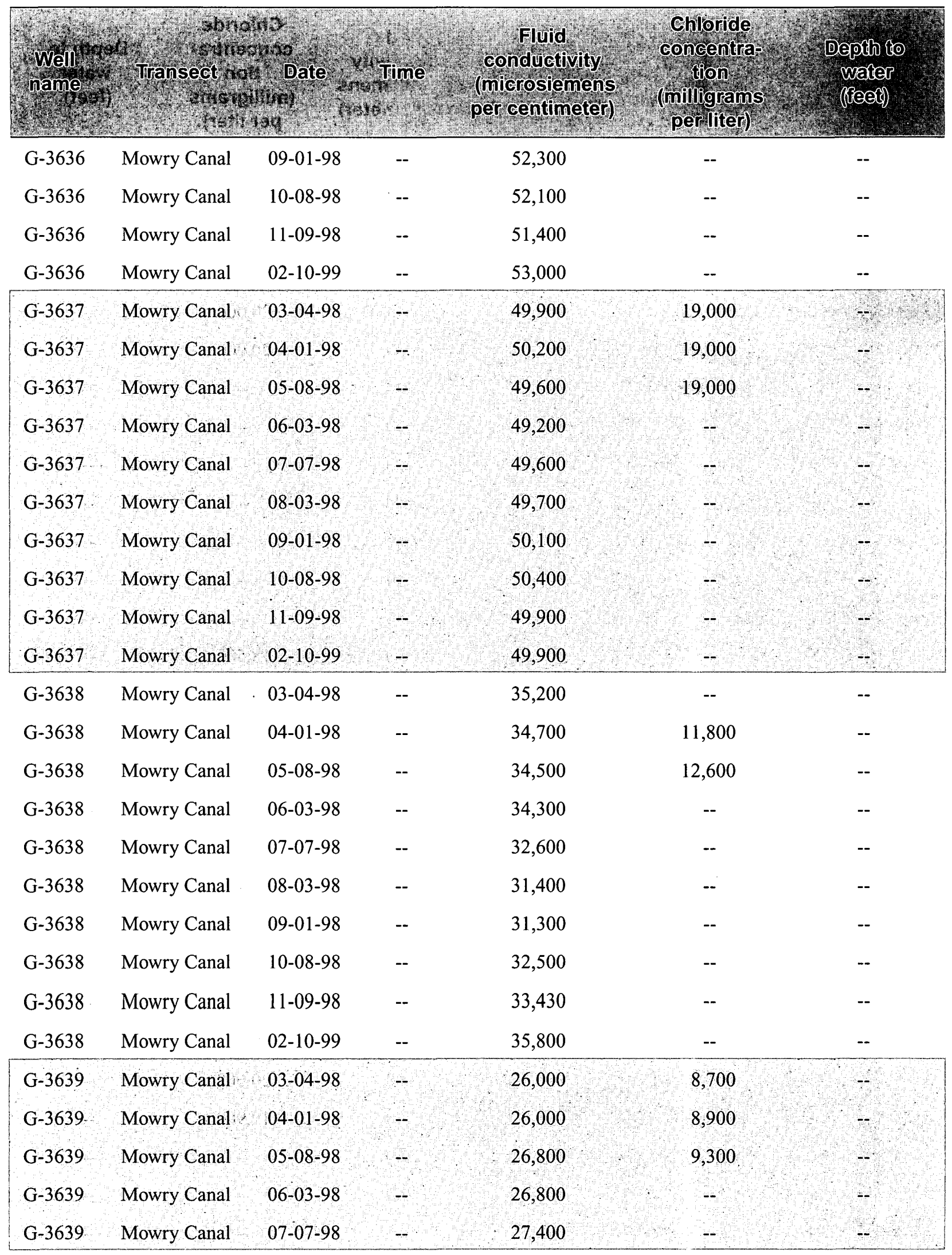




\begin{tabular}{|c|c|c|c|c|c|c|}
\hline $\begin{array}{c}\text { Well } \\
\text { name }\end{array}$ & Transect & Date & Time & $\begin{array}{c}\text { Fluid } \\
\text { conductivity } \\
\text { (microsiemens } \\
\text { per centimeter) }\end{array}$ & $\begin{array}{c}\text { Chloride } \\
\text { concentra- } \\
\text { tion } \\
\text { (milligrams } \\
\text { per liter) }\end{array}$ & $\begin{array}{c}\text { Depth to } \\
\text { water } \\
\text { (feet) }\end{array}$ \\
\hline G-3639 & Mowry Canal & $08-03-98$ & - & 26,900 & -- & -- \\
\hline G-3639 & Mowry Canal & $09-01-98$ & -- & 27,700 & -- & -- \\
\hline G-3639 & Mowry Canal & $10-08-98$ & -- & 27,300 & - & -- \\
\hline G-3639 & Mowry Canal & $11-09-98$ & -- & 27,380 & -- & -- \\
\hline G-3639 & Mowry Canal & $02-10-99$ & -- & 26,100 & -- & -- \\
\hline G-3646 & Deering Estate & $06-02-98$ & -- & 43,300 & -- & -- \\
\hline G-3646 & Deering Estate & $07-08-98$ & -- & 45,200 & -- & -- \\
\hline G-3646 & Deering Estate & 08-03-98 & -- & 44,200 & -- & -- \\
\hline G-3646 & Deering Estate & $09-01-98$ & -- & 42,900 & -- & -- \\
\hline G-3646 & Deering Estate & $10-08-98$ & -- & 43,700 & -- & -- \\
\hline G-3646 & Deering Estate & $11-09-98$ & -- & 39,800 & -- & -- \\
\hline G-3646 & Deering Estate & $02-10-99$ & -- & 42,900 & -- & -- \\
\hline G-3647 & Deering Estate & $06-02-98$ & -- & 12,110 & -- & -- \\
\hline G-3647 & Deering Estate & $07-08-98$ & -- & 12,400 & -- & -- \\
\hline G-3647 & Deering Estate & $08-03-98$ & -- & 12,500 & -- & - \\
\hline G-3647 & Deering Estate & $09-01-98$ & -- & 11,700 & -- & -- \\
\hline G-3647 & Deering Estate & $10-08-98$ & -- & 11,500 & -- & -- \\
\hline G-3647 & Deering Estate & $11-09-98$ & -- & 11,790 & -- & -- \\
\hline G-3647 & Deering Estate & $02-10-99$ & -- & 11,460 & -- & -- \\
\hline G-3648 & Deering Estate & $03-03-98$ & -- & 41,000 & 13,600 & -- \\
\hline G-3648 & Deering Estate & $04-02-98$ & -- & 41,200 & 13,700 & -- \\
\hline G-3648 & Deering Estate & $05-07-98$ & -- & 41,100 & 14,100 & -- \\
\hline G-3648 & Deering Estate & $06-02-98$ & -- & 41,100 & -- & -- \\
\hline G-3648 & Deering Estate & 07-08-98 & -- & 40,900 & -- & -- \\
\hline G-3648 & Deering Estate & $08-03-98$ & -- & 40,600 & -- & -- \\
\hline G-3648 & Deering Estate & $09-01-98$ & -- & 41,100 & -- & -- \\
\hline G-3648 & Deering Estate & $10-08-98$ & -- & 41,400 & -- & -- \\
\hline G-3648 & Deering Estate & $11-09-98$ & -- & 42,100 & -- & -- \\
\hline G-3648 & Deering Estate & $02-10-99$ & -- & 41,700 & -- & -- \\
\hline
\end{tabular}




\begin{tabular}{|c|c|c|c|c|c|c|}
\hline $\begin{array}{l}\text { Well } \\
\text { name }\end{array}$ & Transect & Date & Time & $\begin{array}{c}\text { Fluid } \\
\text { conductivity } \\
\text { (microsiemens } \\
\text { per centimeter) }\end{array}$ & $\begin{array}{l}\text { Chloride } \\
\text { concentra- } \\
\text { tion } \\
\text { (milligrams } \\
\text { per liter) }\end{array}$ & $\begin{array}{l}\text { Bepth to } \\
\text { water } \\
\text { (feet) }\end{array}$ \\
\hline G-3649 & Deering Estate & $03-03-98$ & - & 38,050 & 15,200 & - \\
\hline G-3649 & Deering Estate & $04-02-98$ & -- & 38,300 & 15,100 & -- \\
\hline G-3649 & Deering Estate & $05-07-98$ & - & 38,400 & 15,200 & - \\
\hline G-3649 & Deering Estate & $06-02-98$ & - & 39,300 & - & -- \\
\hline G-3649 & Deering Estate & $07-08-98$ & - & 38,500 & -- & - \\
\hline G-3649 & Deering Estate & $08-03-98$ & - & 37,800 & -- & - \\
\hline G-3649 & Deering Estate & $09-01-98$ & - & 39,100 & - & - \\
\hline G-3649 & Deering Estate & $10-08-98$ & -- & 40,000 & - & - \\
\hline G-3649 & Deering Estate & 11-09-98 & - & 40,000 & - & - \\
\hline G-3649 & Deering Estate & $02-10-99$ & - & 38,400 & - & - \\
\hline G-3650 & Deering Estate & 03-03-98 & -- & 48,000 & 16,200 & -- \\
\hline G-3650 & Deering Estate & $04-02-98$ & -- & 48,100 & 18,200 & -- \\
\hline G-3650 & Deering Estate & $05-07-98$ & -- & 49,000 & -- & -- \\
\hline G-3650 & Deering Estate & $06-02-98$ & -- & 47,500 & -- & -- \\
\hline G-3650 & Deering Estate & $07-08-98$ & -- & 45,500 & -- & -- \\
\hline G-3650 & Deering Estate & $08-03-98$ & -- & 47,200 & -- & -- \\
\hline G-3650 & Deering Estate & $09-01-98$ & -- & 47,200 & -- & -- \\
\hline G-3650 & Deering Estate & $10-08-98$ & -- & 48,300 & -- & -- \\
\hline G-3650 & Deering Estate & $11-09-98$ & -- & 48,200 & -- & -- \\
\hline G-3650 & Deering Estate & $02-10-99$ & -- & 48,000 & -- & -- \\
\hline G-3651 & Deering Estate & $03-03-98$ & - & 43,700 & 18,000 & - \\
\hline G-3651 & Deering Estate & $04-02-98$ & - & 43,800 & 16,200 & -. \\
\hline G-3651 & Deering Estate & $05-07-98$ & - & 43,500 & 16,200 & - \\
\hline G-3651 & Deering Estate & $06-02-98$ & - & 43,500 & - & - \\
\hline G-3651 & Deering Estate & $07-08-98$ & - & 42,700 & - & -- \\
\hline G-3651 & Deering Estate & $08-03-98$ & - & 43,000 & - & - \\
\hline G-3651 & Deering Estate & $09-01-98$ & - & 42,800 & - & - \\
\hline G-3651 & Deering Estate & $10-08-98$ & - & 43,500 & - & - \\
\hline $\mathrm{G}-3651$ & Deering Estate & $11-09-98$ & - & 44,300 & - & $\rightarrow$ \\
\hline$G-3651$ & Deering Estate & 02-10-99 & - & 43,800 & - & 3 \\
\hline
\end{tabular}




\begin{tabular}{|c|c|c|c|c|c|c|}
\hline $\begin{array}{l}\text { Well } \\
\text { name }\end{array}$ & Transect & Date & Time & $\begin{array}{c}\text { Fluid } \\
\text { conductivity } \\
\text { (microsiemens } \\
\text { per centimeter) }\end{array}$ & $\begin{array}{c}\text { Chloride } \\
\text { concentra- } \\
\text { tion } \\
\text { (milligrams } \\
\text { per liter) }\end{array}$ & $\begin{array}{c}\text { Depth to } \\
\text { water } \\
\text { (feet) }\end{array}$ \\
\hline G-3652 & Deering Estate & 11-09-98 & -- & 52,400 & -- & -- \\
\hline G-3652 & Deering Estate & $02-10-99$ & -- & 52,000 & -- & -- \\
\hline G-3654 & Coconut Grove & $03-04-98$ & -- & 33,430 & 11,600 & - \\
\hline G-3654 & Coconut Grove & $04-03-98$ & -- & 33,100 & 11,700 & - \\
\hline G-3654 & Coconut Grove & $05-07-98$ & -- & 32,800 & 11,500 & -- \\
\hline G-3654 & Coconut Grove & $06-02-98$ & -- & 33,500 & -- & -- \\
\hline G-3654 & Coconut Grove & $07-10-98$ & -- & 33,400 & -- & -- \\
\hline G-3654 & Coconut Grove & $08-05-98$ & - & 33,160 & -- & -- \\
\hline G-3654 & Coconut Grove & $09-01-98$ & - & 33,800 & -- & -- \\
\hline G-3654 & Coconut Grove & $10-08-98$ & - & 33,300 & -- & -- \\
\hline G-3654 & Coconut Grove & $11-09-98$ & - & 33,200 & -- & -- \\
\hline G-3654 & Coconut Grove & $02-10-99$ & - & 33,400 & -- & -- \\
\hline G-3656 & Coconut Grove & 03-03-98 & -- & 47,500 & 17,900 & -- \\
\hline G-3656 & Coconut Grove & 04-03-98 & -- & 47,800 & 18,000 & -- \\
\hline G-3656 & Coconut Grove & $05-07-98$ & -- & 47,800 & 18,000 & -- \\
\hline G-3656 & Coconut Grove & $06-02-98$ & -- & 48,200 & -- & -- \\
\hline G-3656 & Coconut Grove & $07-10-98$ & -- & 47,000 & -- & -- \\
\hline G-3656 & Coconut Grove & $08-05-98$ & -- & 45,710 & -- & -- \\
\hline G-3656 & Coconut Grove & 09-01-98 & -- & 46,700 & -- & -- \\
\hline G-3656 & Coconut Grove & $10-08-98$ & -- & 47,900 & -- & -- \\
\hline G-3656 & Coconut Grove & $11-09-98$ & -- & 47,300 & -- & -- \\
\hline G-3657 & Coconut Grove & $05-08-98$ & -- & 45,300 & 17,100 & -- \\
\hline G-3657 & Coconut Grove & $06-02-98$ & - & 46,200 & -- & - \\
\hline G-3657 & Coconut Grove & $07-10-98$ & -- & 46,100 & -- & -- \\
\hline G-3657 & Coconut Grove & $08-05-98$ & -- & 46,100 & -- & -- \\
\hline G-3657 & Coconut Grove & $09-01-98$ & -- & 46,900 & -- & -- \\
\hline G-3657 & Coconut Grove & $10-08-98$ & - & 45,200 & -- & -- \\
\hline G-3657 & Coconut Grove & $11-09-98$ & -- & 46,300 & -- & -- \\
\hline G-3657 & Coconut Grove & $02-10-99$ & -- & 44,200 & -- & -- \\
\hline
\end{tabular}




\begin{tabular}{|c|c|c|c|c|c|c|}
\hline $\begin{array}{l}\text { Well } \\
\text { name }\end{array}$ & Transect & Date & Time & $\begin{array}{c}\text { Fluid } \\
\text { conductivity } \\
\text { (microsiemens } \\
\text { per centimeter) }\end{array}$ & $\begin{array}{c}\text { Chloride } \\
\text { concentra- } \\
\text { tion } \\
\text { (milligrams } \\
\text { per liter) }\end{array}$ & $\begin{array}{l}\text { Depth to } \\
\text { water } \\
\text { (feets) }\end{array}$ \\
\hline G-3659 & Coconut Grove & $03-03-98$ & -- & 43,420 & 16,400 & -- \\
\hline G-3659 & Coconut Grove & $04-02-98$ & -- & 44,100 & 16,500 & -- \\
\hline G-3659 & Coconut Grove & $05-07-98$ & -- & 43,800 & 16,400 & - \\
\hline G-3659 & Coconut Grove & $06-02-98$ & -- & 44,400 & -- & -- \\
\hline G-3659 & Coconut Grove & $08-05-98$ & -- & 44,700 & -- & -- \\
\hline G-3659 & Coconut Grove & $09-01-98$ & -- & 44,700 & -- & -- \\
\hline G-3659 & Coconut Grove & $10-08-98$ & -- & 45,000 & -- & -- \\
\hline G-3659 & Coconut Grove & $11-09-98$ & -- & 45,200 & -- & -- \\
\hline G-3659 & Coconut Grove & $02-10-99$ & -- & 43,100 & -- & -- \\
\hline G-3747 & Coconut Grove & $02-20-98$ & 1126 & - & - & 15.39 \\
\hline G-3747 & Coconut Grove & $03-03-98$ & 0815 & 40,500 & - & 15.46 \\
\hline G-3747 & Coconut Grove & $04-03-98$ & 1038 & 49,100 & 18,500 & 16.72 \\
\hline G-3747 & Coconut Grove & $05-08-98$ & 1325 & - & - & 17.28 \\
\hline G-3747 & Coconut Grove & $06-01-98$ & 0928 & - & -- & 17.14 \\
\hline G-3747 & Coconut Grove & $07-10-98$ & 1105 & 49,400 & - & 17.20 \\
\hline G-3747 & Coconut Grove & $08-05-98$ & 1112 & 49,400 & -- & 17.31 \\
\hline G-3747 & Coconut Grove & $09-02-98$ & 1110 & - & -- & 17.04 \\
\hline G-3747 & Coconut Grove & $10-09-98$ & 1244 & 50,600 & - & 16.70 \\
\hline G-3747 & Coconut Grove & $11-16-98$ & 1456 & 50,900 & - & 16.88 \\
\hline G-3747 & Coconut Grove & $12-18-98$ & 1254 & - & - & 17.02 \\
\hline G-3747 & Coconut Grove & $01-04-99$ & 1153 & - & - & 16.84 \\
\hline G-3747 & Coconut Grove & $02-12-99$ & 0857 & 51,100 & -- & 16.87 \\
\hline G-3747 & Coconut Grove & 03-03-99 & 1227 & - & - & 16.68 \\
\hline G-3748 & Coconut Grove & $03-03-98$ & 0839 & 14,630 & 4,600 & 2.17 \\
\hline G-3748 & Coconut Grove & $04-03-98$ & 0910 & 13,430 & 4,400 & 3.40 \\
\hline G-3748 & Coconut Grove & $05-07-98$ & 1425 & 14,060 & 4,300 & 3.18 \\
\hline G-3748 & Coconut Grove & $06-01-98$ & 0832 & 15,400 & -- & 2.90 \\
\hline G-3748 & Coconut Grove & $07-09-98$ & 1202 & 11,600 & -- & 3.20 \\
\hline G-3748 & Coconut Grove & $08-04-98$ & 0944 & 15,200 & -- & 2.92 \\
\hline
\end{tabular}




\begin{tabular}{|c|c|c|c|c|c|c|}
\hline $\begin{array}{l}\text { Well } \\
\text { name }\end{array}$ & Transect & Date & Time & $\begin{array}{c}\text { Fluid } \\
\text { conductivity } \\
\text { (microsiemens } \\
\text { per centimeter) }\end{array}$ & $\begin{array}{c}\text { Chloride } \\
\text { concentra- } \\
\text { tion } \\
\text { (milligrams } \\
\text { per liter) }\end{array}$ & $\begin{array}{l}\text { Depth to } \\
\text { water } \\
\text { (feet) }\end{array}$ \\
\hline G-3748 & Coconut Grove & $09-02-98$ & 1210 & 13,150 & -- & 2.92 \\
\hline G-3748 & Coconut Grove & $10-05-98$ & 1344 & 11,850 & -- & 2.88 \\
\hline G-3748 & Coconut Grove & $11-10-98$ & 1212 & 14,500 & -- & 2.06 \\
\hline G-3748 & Coconut Grove & $02-12-99$ & 1022 & 16,200 & -- & 2.54 \\
\hline G-3748 & Coconut Grove & 03-03-99 & 1457 & -- & -- & 2.75 \\
\hline G-3749 & Coconut Grove & $02-20-98$ & 1056 & -- & -- & 2.07 \\
\hline G-3749 & Coconut Grove & $03-03-98$ & 0900 & 48,650 & 18,200 & 3.09 \\
\hline G-3749 & Coconut Grove & $04-03-98$ & 0924 & 48,400 & 18,400 & 3.37 \\
\hline G-3749 & Coconut Grove & $05-07-98$ & 1427 & 48,200 & 18,400 & 3.20 \\
\hline G-3749 & Coconut Grove & $06-01-98$ & 0830 & 48,600 & -- & 2.87 \\
\hline G-3749 & Coconut Grove & $07-09-98$ & 1151 & 47,900 & -- & 2.24 \\
\hline G-3749 & Coconut Grove & $08-04-98$ & 0941 & 47,700 & -- & 3.16 \\
\hline G-3749 & Coconut Grove & $09-02-98$ & 1208 & 47,400 & -- & 3.17 \\
\hline G-3749 & Coconut Grove & $10-05-98$ & 1342 & 47,300 & -- & 2.60 \\
\hline G-3749 & Coconut Grove & $11-10-98$ & 1210 & 49,200 & -- & 1.65 \\
\hline G-3749 & Coconut Grove & $02-12-99$ & 1018 & 49,700 & -- & 3.20 \\
\hline G-3749 & Coconut Grove & 03-03-99 & 1447 & -- & -- & 3.37 \\
\hline G-3750 & Coconut Grove & $03-03-98$ & 0850 & 51,200 & 19,100 & 1.98 \\
\hline G-3750 & Coconut Grove & $04-03-98$ & 0928 & 51,200 & 19,000 & 3.64 \\
\hline G-3750 & Coconut Grove & $05-07-98$ & 1429 & 50,600 & 19,400 & 3.49 \\
\hline G-3750 & Coconut Grove & $06-01-98$ & 0828 & 50,600 & -- & 3.28 \\
\hline G-3750 & Coconut Grove & $07-09-98$ & 1150 & 50,600 & -- & 4.70 \\
\hline G-3750 & Coconut Grove & $08-04-98$ & 0940 & 49,900 & -- & 3.48 \\
\hline G-3750 & Coconut Grove & $09-02-98$ & 1203 & 50,300 & -- & 4.52 \\
\hline G-3750 & Coconut Grove & $10-05-98$ & 1340 & 51,100 & -- & 3.52 \\
\hline G-3750 & Coconut Grove & $11-10-98$ & 1208 & 51,600 & -- & 2.82 \\
\hline G-3750 & Coconut Grove & $02-12-99$ & 1017 & 51,500 & -- & 3.27 \\
\hline G-3750 & Coconut Grove & 03-03-99 & 1428 & -- & -- & 3.30 \\
\hline
\end{tabular}




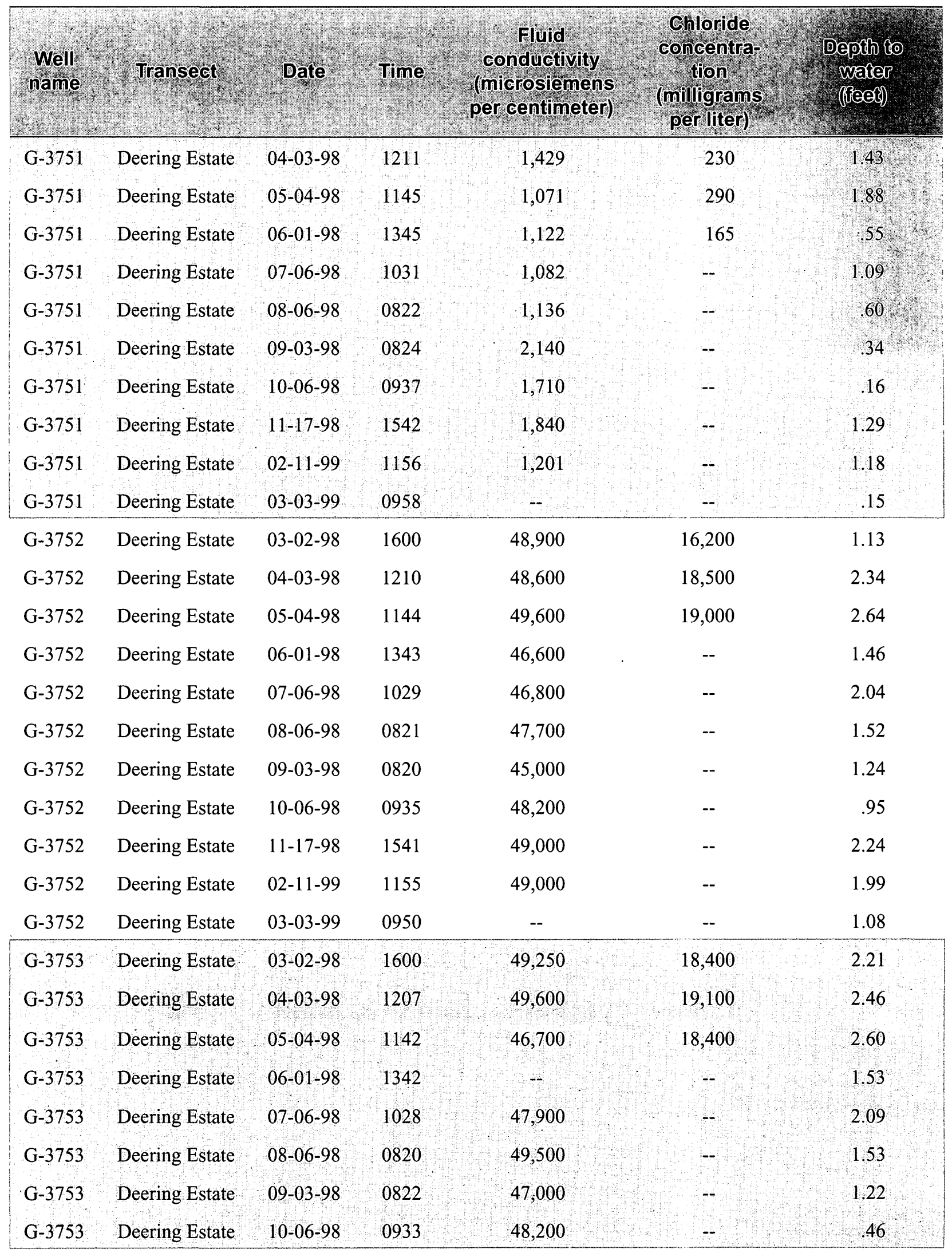




\begin{tabular}{|c|c|c|c|c|c|c|}
\hline $\begin{array}{l}\text { Well } \\
\text { name }\end{array}$ & Transect & Date & Time & $\begin{array}{c}\text { Fluid } \\
\text { conductivity } \\
\text { (microsiemens } \\
\text { per centimeter) }\end{array}$ & $\begin{array}{c}\text { Chloride } \\
\text { concentra- } \\
\text { tion } \\
\text { (milligrams } \\
\text { per liter) }\end{array}$ & $\begin{array}{l}\text { Depth to } \\
\text { water } \\
\text { (feet) }\end{array}$ \\
\hline G-3753 & Deering Estate & $11-17-98$ & 1539 & 49,000 & -- & 2.26 \\
\hline G-3753 & Deering Estate & $02-11-99$ & 1154 & 50,600 & -- & 2.09 \\
\hline G-3753 & Deering Estate & 03-03-99 & 0948 & -- & -- & 1.24 \\
\hline G-3754 & Deering Estate & $03-02-98$ & 1600 & 1,124 & 185 & 1.42 \\
\hline G-3754 & Deering Estate & 04-03-98 & 1205 & 1,175 & 185 & 1.68 \\
\hline G-3754 & Deering Estate & $05-04-98$ & 1137 & 1,360 & 265 & 1.68 \\
\hline G-3754 & Deering Estate & $06-01-98$ & 1340 & 1,052 & -- & .82 \\
\hline G-3754 & Deering Estate & $07-06-98$ & 1026 & 1,028 & -- & 1.30 \\
\hline G-3754 & Deering Estate & $08-06-98$ & 0818 & 1,086 & -- & .88 \\
\hline G-3754 & Deering Estate & 09-03-98 & 0823 & 1,140 & -- & .60 \\
\hline G-3754 & Deering Estate & $10-06-98$ & 0931 & 1,282 & -- & .44 \\
\hline G-3754 & Deering Estate & $11-17-98$ & 1537 & 1,363 & -- & 1.60 \\
\hline G-3754 & Deering Estate & $02-11-99$ & 1153 & 1,140 & -- & 1.40 \\
\hline G-3754 & Deering Estate & 03-03-99 & 0945 & -- & -- & .46 \\
\hline G-3755 & Deering Estate & $04-03-98$ & 1428 & 27,100 & 9,800 & 10.06 \\
\hline G-3755 & Deering Estate & $05-04-98$ & 1540 & 31,300 & 12,300 & 10.36 \\
\hline G-3755 & Deering Estate & $06-01-98$ & 1419 & -- & -- & 10.17 \\
\hline G-3755 & Deering Estate & $07-06-98$ & 0905 & 23,600 & -- & 10.14 \\
\hline G-3755 & Deering Estate & $08-06-98$ & 1024 & 39,000 & -- & 10.32 \\
\hline G-3755 & Deering Estate & $09-02-98$ & 1010 & 39,700 & -- & 10.21 \\
\hline G-3755 & Deering Estate & $10-05-98$ & 1105 & 40,500 & -- & 10.12 \\
\hline G-3755 & Deering Estate & $11-17-98$ & 1409 & 39,800 & -- & 10.30 \\
\hline G-3755 & Deering Estate & $02-12-99$ & 0806 & 40,500 & -- & 10.22 \\
\hline G-3755 & Deering Estate & 03-03-99 & 1016 & -- & -- & 10.15 \\
\hline G-3756 & Mowry Canal & 04-01-98 & 1410 & -- & -- & 3.52 \\
\hline G-3756 & Mowry Canal & $05-05-98$ & 1233 & 50,500 & -- & 4.35 \\
\hline G-3756 & Mowry Canal & 06-04-98 & 1132 & -- & -- & 4.50 \\
\hline G-3756 & Mowry Canal & $07-08-98$ & 0647 & -- & -- & 4.50 \\
\hline G-3756 & Mowry Canal & $08-04-98$ & 0611 & -- & -- & 4.80 \\
\hline
\end{tabular}




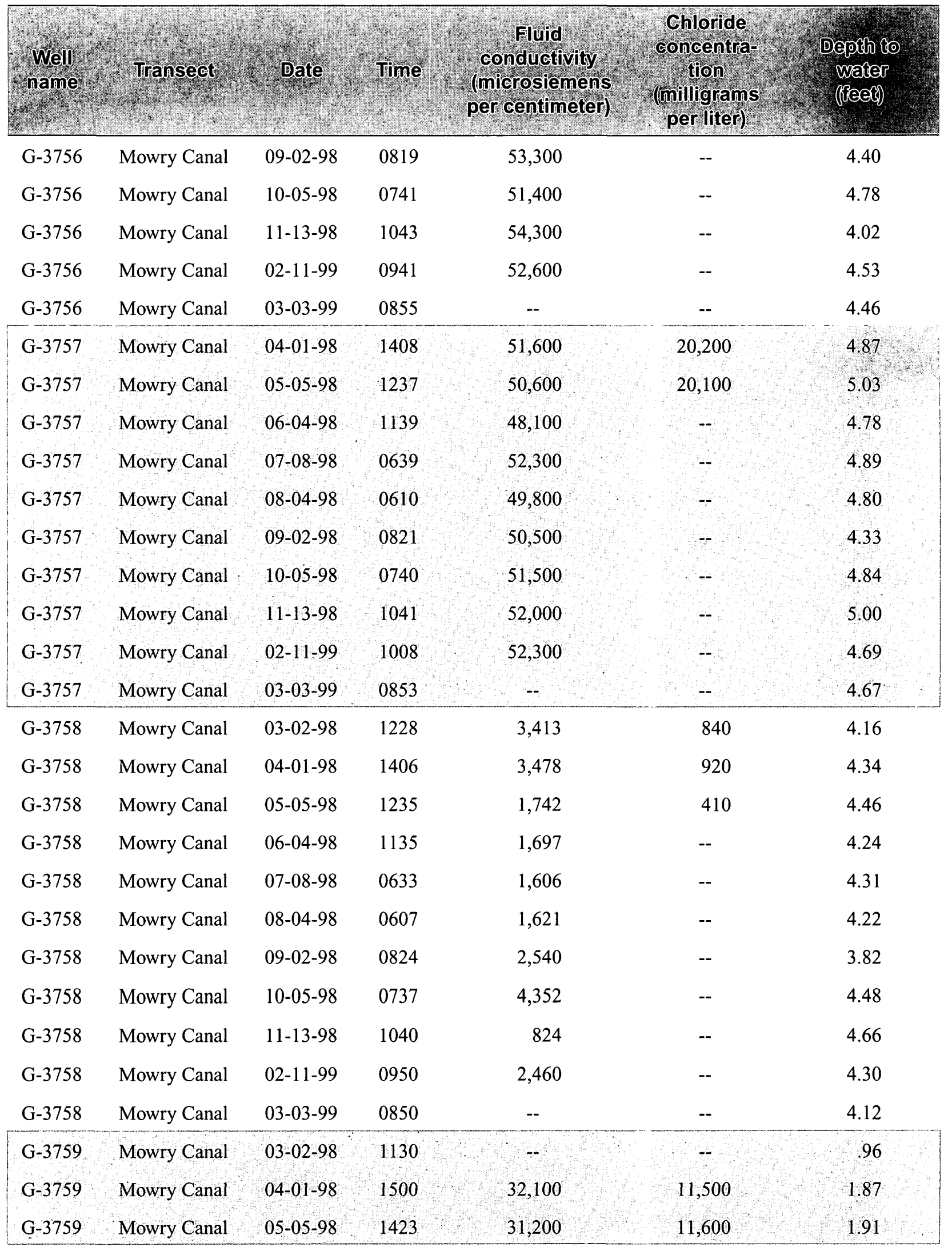




\begin{tabular}{|ccccccc|}
\hline $\begin{array}{c}\text { Well } \\
\text { name }\end{array}$ & Transect & Date & Time & $\begin{array}{c}\text { Fluid } \\
\text { conductivity } \\
\text { (microsiemens } \\
\text { per centimeter) }\end{array}$ & $\begin{array}{c}\text { Chloride } \\
\text { concentra- } \\
\text { tion } \\
\text { (milligrams } \\
\text { per liter) }\end{array}$ & $\begin{array}{c}\text { Depth to } \\
\text { water } \\
\text { (feet) }\end{array}$ \\
\hline G-3759 & Mowry Canal & $06-04-98$ & 1025 & 32,100 & -- & 1.90 \\
G-3759 & Mowry Canal & $07-06-98$ & 1333 & 30,400 & -- & 2.09 \\
G-3759 & Mowry Canal & $08-06-98$ & 0630 & 32,800 & -- & 1.89 \\
G-3759 & Mowry Canal & $09-02-98$ & 0722 & 32,900 & -- & 1.78 \\
G-3759 & Mowry Canal & $10-13-98$ & 0743 & 33,000 & -- & 2.26 \\
G-3759 & Mowry Canal & $11-13-98$ & 0936 & 33,900 & -- & 2.53 \\
G-3759 & Mowry Canal & $02-11-99$ & 0837 & 33,700 & -- & 2.34 \\
G-3759 & Mowry Canal & $03-03-99$ & 0838 & -- & -- & 2.31 \\
\hline
\end{tabular}




\section{Appendix III. Monitoring Stations Used in this Study}

\begin{tabular}{|c|c|c|c|c|}
\hline Station name & Station type & Latitude & Longitude & Data source \\
\hline F-179 & Monitoring well $^{1}$ & $25^{\circ} 44^{\prime} 44^{\prime \prime}$ & $80^{\circ} 14^{\prime} 48^{\prime \prime}$ & NWIS \\
\hline F-239 & Monitoring well $^{1}$ & $25^{\circ} 50^{\prime} 08^{\prime \prime}$ & $80^{\circ} 16^{\prime} 18^{\prime \prime}$ & NWIS \\
\hline F-319 & Monitoring well ${ }^{1}$ & $25^{\circ} 42^{\prime} 17^{\prime \prime}$ & $80^{\circ} 17^{\prime} 18^{\prime \prime}$ & NWIS \\
\hline $\mathrm{F}-358$ & Monitoring well ${ }^{1}$ & $25^{\circ} 28^{\prime} 29^{\prime \prime}$ & $80^{\circ} 28^{\prime} 51^{\prime \prime}$ & NWIS \\
\hline F-45 & Monitoring well ${ }^{1,2}$ & $25^{\circ} 49^{\prime} 43^{\prime \prime}$ & $80^{\circ} 12^{\prime} 15^{\prime \prime}$ & NWIS \\
\hline G-1166 & Monitoring well $^{1}$ & $25^{\circ} 53^{\prime} 42^{\prime \prime}$ & $80^{\circ} 19^{\prime} 55^{\prime \prime}$ & NWIS \\
\hline G-1183 & Monitoring well ${ }^{1,2}$ & $25^{\circ} 29^{\prime} 18^{\prime \prime}$ & $80^{\circ} 23^{\prime} 42^{\prime \prime}$ & NWIS \\
\hline G-1251 & Monitoring well $^{1}$ & $25^{\circ} 19^{\prime} 16^{\prime \prime}$ & $80^{\circ} 33^{\prime} 57^{\prime \prime}$ & NWIS \\
\hline G-1362 & Monitoring well $^{1}$ & $25^{\circ} 36^{\prime} 37^{\prime \prime}$ & $80^{\circ} 26^{\prime} 47^{\prime \prime}$ & NWIS \\
\hline G-1363 & Monitoring well ${ }^{1}$ & $25^{\circ} 32^{\prime} 33^{\prime \prime}$ & $80^{\circ} 30^{\prime} 10^{\prime \prime}$ & NWIS \\
\hline G- $1368 \mathrm{~A}$ & Monitoring well $^{1}$ & $25^{\circ} 49^{\prime} 50^{\prime \prime}$ & $80^{\circ} 17^{\prime} 12^{\prime \prime}$ & NWIS \\
\hline G-1487 & Monitoring well $^{1}$ & $25^{\circ} 40^{\prime} 55^{\prime \prime}$ & $80^{\circ} 29^{\prime} 55^{\prime \prime}$ & NWIS \\
\hline G-1488 & Monitoring well $^{1}$ & $25^{\circ} 49^{\prime} 05^{\prime \prime}$ & $80^{\circ} 28^{\prime} 55^{\prime \prime}$ & NWIS \\
\hline G-1502 & Monitoring well $^{1}$ & $25^{\circ} 36^{\prime} 55^{\prime \prime}$ & $80^{\circ} 35^{\prime} 05^{\prime \prime}$ & NWIS \\
\hline G-1636 & Monitoring well ${ }^{1}$ & $25^{\circ} 58^{\prime} 07^{\prime \prime}$ & $80^{\circ} 22^{\prime} 43^{\prime \prime}$ & NWIS \\
\hline G-1637 & Monitoring well ${ }^{1}$ & $25^{\circ} 57^{\prime} 07^{\prime \prime}$ & $80^{\circ} 25^{\prime} 50^{\prime \prime}$ & NWIS \\
\hline G-3 & Monitoring well $^{1}$ & $25^{\circ} 49^{\prime} 50^{\prime \prime}$ & $80^{\circ} 18^{\prime} 08^{\prime \prime}$ & NWIS \\
\hline G-3074 & Monitoring well $^{1}$ & $25^{\circ} 41^{\prime} 57^{\prime \prime}$ & $80^{\circ} 21^{\prime} 40^{\prime \prime}$ & NWIS \\
\hline G-3253 & Monitoring well ${ }^{1}$ & $25^{\circ} 50^{\prime} 27^{\prime \prime}$ & $80^{\circ} 24^{\prime} 55^{\prime \prime}$ & NWIS \\
\hline G-3259A & Monitoring well $^{1}$ & $25^{\circ} 50^{\prime} 26^{\prime \prime}$ & $80^{\circ} 24^{\prime} 03^{\prime \prime}$ & NWIS \\
\hline G-3264A & Monitoring well ${ }^{1}$ & $25^{\circ} 50^{\prime} 27^{\prime \prime}$ & $80^{\circ} 22^{\prime} 16^{\prime \prime}$ & NWIS \\
\hline G-3327 & Monitoring well $^{1}$ & $25^{\circ} 48^{\prime} 23^{\prime \prime}$ & $80^{\circ} 16^{\prime} 37^{\prime \prime}$ & NWIS \\
\hline G-3328 & Monitoring well $^{1}$ & $25^{\circ} 47^{\prime} 41^{\prime \prime}$ & $80^{\circ} 16^{\prime} 21^{\prime \prime}$ & NWIS \\
\hline G-3329 & Monitoring well $^{1}$ & $25^{\circ} 47^{\prime} 52^{\prime \prime}$ & $80^{\circ} 18^{\prime} 15^{\prime \prime}$ & NWIS \\
\hline G-3353 & Monitoring well $^{1}$ & $25^{\circ} 17^{\prime} 24^{\prime \prime}$ & $80^{\circ} 34^{\prime} 14^{\prime \prime}$ & NWIS \\
\hline G-3354 & Monitoring well $^{1}$ & $25^{\circ} 18^{\prime} 55^{\prime \prime}$ & $80^{\circ} 28^{\prime} 34^{\prime \prime}$ & NWIS \\
\hline G-3355 & Monitoring well $^{1}$ & $25^{\circ} 23^{\prime} 32^{\prime \prime}$ & $80^{\circ} 30^{\prime} 05^{\prime \prime}$ & NWIS \\
\hline G-3356 & Monitoring well ${ }^{1}$ & $25^{\circ} 25^{\prime} 06^{\prime \prime}$ & $80^{\circ} 25^{\prime} 41^{\prime \prime}$ & NWIS \\
\hline
\end{tabular}




\section{Statfon name}

\section{Station type}

Latitude

Longitude

Data source

\begin{tabular}{|c|c|c|c|c|}
\hline G-3437 & Monitoring well ${ }^{1}$ & $25^{\circ} 34^{\prime} 00^{\prime \prime}$ & $80^{\circ} 34^{\prime} 04^{\prime \prime}$ & NWIS \\
\hline G-3439 & Monitoring well ${ }^{1}$ & $25^{\circ} 44^{\prime} 21^{\prime \prime}$ & $80^{\circ} 26^{\prime} 02^{\prime \prime}$ & NWIS \\
\hline G-3465 & Monitoring well ${ }^{1}$ & $25^{\circ} 48^{\prime} 23^{\prime \prime}$ & $80^{\circ} 17^{\prime} 52^{\prime \prime}$ & NWIS \\
\hline G-3466 & Monitoring well ${ }^{1}$ & $25^{\circ} 48^{\prime} 34^{\prime \prime}$ & $80^{\circ} 17^{\prime} 16^{\prime \prime}$ & NWIS \\
\hline G-3467 & Monitoring well ${ }^{1}$ & $25^{\circ} 48^{\prime} 39^{\prime \prime}$ & $80^{\circ} 16^{\prime} 23^{\prime \prime}$ & NWIS \\
\hline G-551 & Monitoring well ${ }^{1}$ & $25^{\circ} 41^{\prime} 30^{\prime \prime}$ & $80^{\circ} 23^{\prime} 45^{\prime \prime}$ & NWIS \\
\hline G-553 & Monitoring well ${ }^{1}$ & $25^{\circ} 39^{\prime} 02^{\prime \prime}$ & $80^{\circ} 20^{\prime} 19^{\prime \prime}$ & NWIS \\
\hline G-580A & Monitoring well ${ }^{1}$ & $25^{\circ} 40^{\prime} 00^{\prime \prime}$ & $80^{\circ} 18^{\prime} 10^{\prime \prime}$ & NWIS \\
\hline G-596 & Monitoring well ${ }^{1}$ & $25^{\circ} 38^{\prime} 16^{\prime \prime}$ & $80^{\circ} 30^{\prime} 44^{\prime \prime}$ & NWIS \\
\hline G-613 & Monitoring well ${ }^{1}$ & $25^{\circ} 24^{\prime} 25^{\prime \prime}$ & $80^{\circ} 32^{\prime} 00^{\prime \prime}$ & NWIS \\
\hline G-614 & Monitoring well ${ }^{1}$ & $25^{\circ} 32^{\prime} 58^{\prime \prime}$ & $80^{\circ} 26^{\prime} 43^{\prime \prime}$ & NWIS \\
\hline G-618 & Monitoring well ${ }^{1}$ & $25^{\circ} 45^{\prime} 40^{\prime \prime}$ & $80^{\circ} 35^{\prime} 60^{\prime \prime}$ & NWIS \\
\hline G-620 & Monitoring well ${ }^{1}$ & $25^{\circ} 40^{\prime} 00^{\prime \prime}$ & $80^{\circ} 46^{\prime} 00^{\prime \prime}$ & NWIS \\
\hline G-757A & Monitoring well ${ }^{1}$ & $25^{\circ} 35^{\prime} 37^{\prime \prime}$ & $80^{\circ} 28^{\prime} 44^{\prime \prime}$ & NWIS \\
\hline G-789 & Monitoring well ${ }^{1}$ & $25^{\circ} 29^{\prime} 28^{\prime \prime}$ & $80^{\circ} 33^{\prime} 24^{\prime \prime}$ & NWIS \\
\hline G-852 & Monitoring well ${ }^{1}$ & $25^{\circ} 54^{\prime} 37^{\prime \prime}$ & $80^{\circ} 10^{\prime} 32^{\prime \prime}$ & NWIS \\
\hline G-855 & Monitoring well $^{1}$ & $25^{\circ} 40^{\prime} 38^{\prime \prime}$ & $80^{\circ} 28^{\prime} 02^{\prime \prime}$ & NWIS \\
\hline G-860 & Monitoring well ${ }^{1}$ & $25^{\circ} 37^{\prime} 18^{\prime \prime}$ & $80^{\circ} 19^{\prime} 23^{\prime \prime}$ & NWIS \\
\hline G-864 & Monitoring well ${ }^{1}$ & $25^{\circ} 26^{\prime} 12^{\prime \prime}$ & $80^{\circ} 30^{\prime} 07^{\prime \prime}$ & NWIS \\
\hline G-864A & Monitoring well ${ }^{1}$ & $25^{\circ} 26^{\prime} 08^{\prime \prime}$ & $80^{\circ} 30^{\prime} 32^{\prime \prime}$ & NWIS \\
\hline G-968 & Monitoring well ${ }^{1}$ & $25^{\circ} 55^{\prime} 60^{\prime \prime}$ & $80^{\circ} 27^{\prime} 00^{\prime \prime}$ & NWIS \\
\hline G-970 & Monitoring well ${ }^{1}$ & $25^{\circ} 57^{\prime} 09^{\prime \prime}$ & $80^{\circ} 22^{\prime} 37^{\prime \prime}$ & NWIS \\
\hline G-973 & Monitoring well $^{1}$ & $25^{\circ} 52^{\prime} 09^{\prime \prime}$ & $80^{\circ} 21^{\prime} 28^{\prime \prime}$ & NWIS \\
\hline G-975 & Monitoring well ${ }^{1}$ & $25^{\circ} 52^{\prime} 08^{\prime \prime}$ & $80^{\circ} 27^{\prime} 40^{\prime \prime}$ & NWIS \\
\hline G-976 & Monitoring well $^{1}$ & $25^{\circ} 49^{\prime} 18^{\prime \prime}$ & $80^{\circ} 25^{\prime} 33^{\prime \prime}$ & NWIS \\
\hline S-18 & Monitoring well ${ }^{1}$ & $25^{\circ} 55^{\prime} 26^{\prime \prime}$ & $80^{\circ} 14^{\prime} 30^{\prime \prime}$ & NWIS \\
\hline S-182A & Monitoring well ${ }^{1}$ & $25^{\circ} 35^{\prime} 49^{\prime \prime}$ & $80^{\circ} 21^{\prime} 41^{\prime \prime}$ & NWIS \\
\hline S-19 & Monitoring well ${ }^{1}$ & $25^{\circ} 48^{\prime} 32^{\prime \prime}$ & $80^{\circ} 17^{\prime} 50^{\prime \prime}$ & NWIS \\
\hline S-196A & Monitoring well ${ }^{1}$ & $25^{\circ} 30^{\prime} 29^{\prime \prime}$ & $80^{\circ} 29^{\prime} 56^{\prime \prime}$ & NWIS \\
\hline S-68 & Monitoring well ${ }^{1}$ & $25^{\circ} 48^{\prime} 55^{\prime \prime}$ & $80^{\circ} 17^{\prime} 10^{\prime \prime}$ & NWIS \\
\hline
\end{tabular}




\begin{tabular}{|c|c|c|c|c|}
\hline Station name & Station type & Latitude & Longitude & Data source \\
\hline F-279 & Monitoring well ${ }^{2}$ & $25^{\circ} 53^{\prime} 15^{\prime \prime}$ & $80^{\circ} 11^{\prime} 15^{\prime \prime}$ & NWIS \\
\hline G-1009B & Monitoring well ${ }^{2}$ & $25^{\circ} 41^{\prime} 06^{\prime \prime}$ & $80^{\circ} 17^{\prime} 46^{\prime \prime}$ & NWIS \\
\hline G-1179 & Monitoring well ${ }^{2}$ & $25^{\circ} 29^{\prime} 44^{\prime \prime}$ & $80^{\circ} 23^{\prime} 34^{\prime \prime}$ & NWIS \\
\hline G-1180 & Monitoring well ${ }^{2}$ & $25^{\circ} 29^{\prime} 47^{\prime \prime}$ & $80^{\circ} 23^{\prime} 53^{\prime \prime}$ & NWIS \\
\hline G-1351 & Monitoring well $^{2}$ & $25^{\circ} 48^{\prime} 13^{\prime \prime}$ & $80^{\circ} 16^{\prime} 15^{\prime \prime}$ & NWIS \\
\hline G-1354 & Monitoring well ${ }^{2}$ & $25^{\circ} 48^{\prime} 33^{\prime \prime}$ & $80^{\circ} 15^{\prime} 58^{\prime \prime}$ & NWIS \\
\hline G-3157 & Monitoring well ${ }^{2}$ & $25^{\circ} 39^{\prime} 58^{\prime \prime}$ & $80^{\circ} 18^{\prime} 30^{\prime \prime}$ & NWIS \\
\hline G-3162 & Monitoring well ${ }^{2}$ & $25^{\circ} 31^{\prime} 32^{\prime \prime}$ & $80^{\circ} 23^{\prime} 25^{\prime \prime}$ & NWIS \\
\hline G-3224 & Monitoring well ${ }^{2}$ & $25^{\circ} 52^{\prime} 22^{\prime \prime}$ & $80^{\circ} 12^{\prime} 30^{\prime \prime}$ & NWIS \\
\hline G-3226 & Monitoring well ${ }^{2}$ & $25^{\circ} 49^{\prime} 23^{\prime \prime}$ & $80^{\circ} 12^{\prime} 02^{\prime \prime}$ & NWIS \\
\hline G-3229 & Monitoring well ${ }^{2}$ & $25^{\circ} 44^{\prime} 57^{\prime \prime}$ & $80^{\circ} 16^{\prime} 03^{\prime \prime}$ & NWIS \\
\hline G-3235A & Monitoring well ${ }^{2}$ & $25^{\circ} 28^{\prime} 24^{\prime \prime}$ & $80^{\circ} 25^{\prime} 06^{\prime \prime}$ & NWIS \\
\hline G-3250 & Monitoring well ${ }^{2}$ & $25^{\circ} 49^{\prime} 46^{\prime \prime}$ & $80^{\circ} 17^{\prime} 26^{\prime \prime}$ & NWIS \\
\hline G-3313C & Monitoring well ${ }^{2}$ & $25^{\circ} 38^{\prime} 31^{\prime \prime}$ & $80^{\circ} 18^{\prime} 02^{\prime \prime}$ & NWIS \\
\hline G-3313E & Monitoring well ${ }^{2}$ & $25^{\circ} 38^{\prime} 31^{\prime \prime}$ & $80^{\circ} 18^{\prime} 02^{\prime \prime}$ & NWIS \\
\hline G-354 & Monitoring well ${ }^{2}$ & $25^{\circ} 48^{\prime} 28^{\prime \prime}$ & $80^{\circ} 16^{\prime} 15^{\prime \prime}$ & NWIS \\
\hline G-3600 & Monitoring well ${ }^{2}$ & $25^{\circ} 56^{\prime} 26^{\prime \prime}$ & $80^{\circ} 09^{\prime} 32^{\prime \prime}$ & NWIS \\
\hline G-3601 & Monitoring well ${ }^{2}$ & $25^{\circ} 53^{\prime} 58^{\prime \prime}$ & $80^{\circ} 11^{\prime} 41^{\prime \prime}$ & NWIS \\
\hline G-3602 & Monitoring well ${ }^{2}$ & $25^{\circ} 51^{\prime} 16^{\prime \prime}$ & $80^{\circ} 12^{\prime} 06^{\prime \prime}$ & NWIS \\
\hline G-3603 & Monitoring well ${ }^{2}$ & $25^{\circ} 49^{\prime} 08^{\prime \prime}$ & $80^{\circ} 12^{\prime} 52^{\prime \prime}$ & NWIS \\
\hline G-3604 & Monitoring well $^{2}$ & $25^{\circ} 47^{\prime} 22^{\prime \prime}$ & $80^{\circ} 15^{\prime} 22^{\prime \prime}$ & NWIS \\
\hline G-3605 & Monitoring well ${ }^{2}$ & $25^{\circ} 46^{\prime} 29^{\prime \prime}$ & $80^{\circ} 14^{\prime} 31^{\prime \prime}$ & NWIS \\
\hline G-3606 & Monitoring well ${ }^{2}$ & $25^{\circ} 43^{\prime} 41^{\prime \prime}$ & $80^{\circ} 17^{\prime} 40^{\prime \prime}$ & NWIS \\
\hline G-3607 & Monitoring well ${ }^{2}$ & $25^{\circ} 41^{\prime} 56^{\prime \prime}$ & $80^{\circ} 17^{\prime} 21^{\prime \prime}$ & NWIS \\
\hline G-3608 & Monitoring well $^{2}$ & $25^{\circ} 41^{\prime} 08^{\prime \prime}$ & $80^{\circ} 17^{\prime} 06^{\prime \prime}$ & NWIS \\
\hline G-3609 & Monitoring well ${ }^{2}$ & $25^{\circ} 40^{\prime} 05^{\prime \prime}$ & $80^{\circ} 17^{\prime} 16^{\prime \prime}$ & NWIS \\
\hline G-3610 & Monitoring well ${ }^{2}$ & $25^{\circ} 38^{\prime} 19^{\prime \prime}$ & $80^{\circ} 18^{\prime} 32^{\prime \prime}$ & NWIS \\
\hline G-3611 & Monitoring well ${ }^{2}$ & $25^{\circ} 37^{\prime} 10^{\prime \prime}$ & $80^{\circ} 18^{\prime} 47^{\prime \prime}$ & NWIS \\
\hline G-3612 & Monitoring well ${ }^{2}$ & $25^{\circ} 34^{\prime} 57^{\prime \prime}$ & $80^{\circ} 19^{\prime} 55^{\prime \prime}$ & NWIS \\
\hline G-3613 & Monitoring well ${ }^{2}$ & $25^{\circ} 32^{\prime} 14^{\prime \prime}$ & $80^{\circ} 21^{\prime} 54^{\prime \prime}$ & NWIS \\
\hline
\end{tabular}




\begin{tabular}{|c|c|c|c|c|}
\hline Station name & Station type & Latitude & Longitude & Data source \\
\hline G-3615 & Monitoring well $^{2}$ & $25^{\circ} 30^{\prime} 24^{\prime \prime}$ & $80^{\circ} 23^{\prime} 10^{\prime \prime}$ & NWIS \\
\hline G-432 & Monitoring well $^{2}$ & $25^{\circ} 43^{\prime} 35^{\prime \prime}$ & $80^{\circ} 17^{\prime} 05^{\prime \prime}$ & NWIS \\
\hline G-548 & Monitoring well $^{2}$ & $25^{\circ} 48^{\prime} 55^{\prime \prime}$ & $80^{\circ} 16^{\prime} 37^{\prime \prime}$ & NWIS \\
\hline G-571 & Monitoring well $^{2}$ & $25^{\circ} 48^{\prime} 41^{\prime \prime}$ & $80^{\circ} 16^{\prime} 44^{\prime \prime}$ & NWIS \\
\hline G-894 & Monitoring well $^{2}$ & $25^{\circ} 53^{\prime} 50^{\prime \prime}$ & $80^{\circ} 10^{\prime} 58^{\prime \prime}$ & NWIS \\
\hline G-896 & Monitoring well $^{2}$ & $25^{\circ} 41^{\prime} 07^{\prime \prime}$ & $80^{\circ} 16^{\prime} 52^{\prime \prime}$ & NWIS \\
\hline G-901 & Monitoring well $^{2}$ & $25^{\circ} 42^{\prime} 01^{\prime \prime}$ & $80^{\circ} 17^{\prime} 30^{\prime \prime}$ & NWIS \\
\hline G-939 & Monitoring well ${ }^{2}$ & $25^{\circ} 36^{\prime} 52^{\prime \prime}$ & $80^{\circ} 18^{\prime} 37^{\prime \prime}$ & NWIS \\
\hline POMPANOF_R & Rainfall station ${ }^{3}$ & $26^{\circ} 13^{\prime} 59^{\prime \prime}$ & $80^{\circ} 08^{\prime} 24^{\prime \prime}$ & DBHYDRO \\
\hline S36_R & Rainfall station ${ }^{3}$ & $26^{\circ} 10^{\prime} 24^{\prime \prime}$ & $80^{\circ} 10^{\prime} 42^{\prime \prime}$ & DBHYDRO \\
\hline 3A-36_R & Rainfall station ${ }^{3}$ & $26^{\circ} 11^{\prime} 29^{\prime \prime}$ & $80^{\circ} 26^{\prime} 57^{\prime \prime}$ & DBHYDRO \\
\hline DIXIE WA_R & Rainfall station ${ }^{3}$ & $26^{\circ} 06^{\prime} 05^{\prime \prime}$ & $80^{\circ} 11^{\prime} 59^{\prime \prime}$ & DBHYDRO \\
\hline G54_R & Rainfall station ${ }^{3}$ & $26^{\circ} 05^{\prime} 40^{\prime \prime}$ & $80^{\circ} 13^{\prime} 49^{\prime \prime}$ & DBHYDRO \\
\hline S13_R & Rainfall station ${ }^{3}$ & $26^{\circ} 03^{\prime} 58^{\prime \prime}$ & $80^{\circ} 12^{\prime} 31^{\prime \prime}$ & DBHYDRO \\
\hline GILL REA_R & Rainfall station ${ }^{3}$ & $26^{\circ} 03^{\prime} 37^{\prime \prime}$ & $80^{\circ} 13^{\prime} 54^{\prime \prime}$ & DBHYDRO \\
\hline S9_R & Rainfall station ${ }^{3}$ & $26^{\circ} 03^{\prime} 41^{\prime \prime}$ & $80^{\circ} 26^{\prime} 29^{\prime \prime}$ & DBHYDRO \\
\hline S140 SPW_R & Rainfall station ${ }^{3}$ & $26^{\circ} 10^{\prime} 19^{\prime \prime}$ & $80^{\circ} 49^{\prime} 38^{\prime \prime}$ & DBHYDRO \\
\hline FT. LAUD_R & Rainfall station ${ }^{3}$ & $26^{\circ} 03^{\prime} 49^{\prime \prime}$ & $80^{\circ} 15^{\prime} 34^{\prime \prime}$ & DBHYDRO \\
\hline 3A-NW_R & Rainfall station ${ }^{3}$ & $26^{\circ} 17^{\prime} 08^{\prime \prime}$ & $80^{\circ} 46^{\prime} 33^{\prime \prime}$ & DBHYDRO \\
\hline 3A-NE_R & Rainfall station ${ }^{3}$ & $26^{\circ} 16^{\prime} 43^{\prime \prime}$ & $80^{\circ} 36^{\prime} 18^{\prime \prime}$ & DBHYDRO \\
\hline 3A-S_R & Rainfall station ${ }^{3}$ & $26^{\circ} 05^{\prime} 00^{\prime \prime}$ & $80^{\circ} 41^{\prime} 04^{\prime \prime}$ & DBHYDRO \\
\hline 3A-SW_R & Rainfall station ${ }^{3}$ & $25^{\circ} 59^{\prime} 23^{\prime \prime}$ & $80^{\circ} 50^{\prime} 10^{\prime \prime}$ & DBHYDRO \\
\hline FORT LAU_R & Rainfall station ${ }^{3}$ & $26^{\circ} 06^{\prime} 05^{\prime \prime}$ & $80^{\circ} 11^{\prime} 59^{\prime \prime}$ & DBHYDRO \\
\hline POMPANOB_R & Rainfall station ${ }^{3}$ & $26^{\circ} 14^{\prime} 01^{\prime \prime}$ & $80^{\circ} 08^{\prime} 59^{\prime \prime}$ & DBHYDRO \\
\hline S9_R & Rainfall station ${ }^{3}$ & $26^{\circ} 03^{\prime} 41^{\prime \prime}$ & $80^{\circ} 26^{\prime} 29^{\prime \prime}$ & DBHYDRO \\
\hline SBDD & Rainfall station ${ }^{3}$ & $26^{\circ} 02^{\prime} 16^{\prime \prime}$ & $80^{\circ} 21^{\prime} 44^{\prime \prime}$ & DBHYDRO \\
\hline S140W & Rainfall station ${ }^{3}$ & $26^{\circ} 10^{\prime} 19^{\prime \prime}$ & $80^{\circ} 49^{\prime} 38^{\prime \prime}$ & DBHYDRO \\
\hline 3A-36_R & Rainfall station ${ }^{3}$ & $26^{\circ} 11^{\prime} 29^{\prime \prime}$ & $80^{\circ} 26^{\prime} 57^{\prime \prime}$ & DBHYDRO \\
\hline S124_R & Rainfall station ${ }^{3}$ & $26^{\circ} 07^{\prime} 45^{\prime \prime}$ & $80^{\circ} 21^{\prime} 56^{\prime \prime}$ & DBHYDRO \\
\hline S13_R & Rainfall station ${ }^{3}$ & $26^{\circ} 03^{\prime} 58^{\prime \prime}$ & $80^{\circ} 12^{\prime} 31^{\prime \prime}$ & DBHYDRO \\
\hline
\end{tabular}




\begin{tabular}{|c|c|c|c|c|}
\hline Station name & Station type & Latitude & Longitude & Data source \\
\hline S140_R & Rainfall station ${ }^{3}$ & $26^{\circ} 10^{\prime} 19^{\prime \prime}$ & $80^{\circ} 49^{\prime} 38^{\prime \prime}$ & DBHYDRO \\
\hline S9_R & Rainfall station ${ }^{3}$ & $26^{\circ} 03^{\prime} 41^{\prime \prime}$ & $80^{\circ} 26^{\prime} 29^{\prime \prime}$ & DBHYDRO \\
\hline S30_R & Rainfall station ${ }^{3}$ & $25^{\circ} 57^{\prime} 24^{\prime \prime}$ & $80^{\circ} 25^{\prime} 53^{\prime \prime}$ & DBHYDRO \\
\hline S37B_R & Rainfall station ${ }^{3}$ & $26^{\circ} 13^{\prime} 26^{\prime \prime}$ & $80^{\circ} 10^{\prime} 15^{\prime \prime}$ & DBHYDRO \\
\hline FTL & Rainfall station ${ }^{3}$ & $26^{\circ} 05^{\prime} 34^{\prime \prime}$ & $80^{\circ} 12^{\prime} 23^{\prime \prime}$ & DBHYDRO \\
\hline HOLLYWOOD & Rainfall station ${ }^{3}$ & $26^{\circ} 02^{\prime} 54^{\prime \prime}$ & $80^{\circ} 07^{\prime} 39^{\prime \prime}$ & DBHYDRO \\
\hline CORAL SP W & Rainfall station ${ }^{3}$ & $26^{\circ} 17^{\prime} 01^{\prime \prime}$ & $80^{\circ} 24^{\prime} 59^{\prime \prime}$ & DBHYDRO \\
\hline CORAL SP & Rainfall station ${ }^{3}$ & $26^{\circ} 17^{\prime} 01^{\prime \prime}$ & $80^{\circ} 18^{\prime} 59^{\prime \prime}$ & DBHYDRO \\
\hline BONAVENTUR & Rainfall station ${ }^{3}$ & $26^{\circ} 08^{\prime} 01^{\prime \prime}$ & $80^{\circ} 21^{\prime} 59^{\prime \prime}$ & DBHYDRO \\
\hline ANDYTOWN W & Rainfall station ${ }^{3}$ & $26^{\circ} 11^{\prime} 01^{\prime \prime}$ & $80^{\circ} 31^{\prime} 59^{\prime \prime}$ & DBHYDRO \\
\hline S38_R & Rainfall station ${ }^{3}$ & $26^{\circ} 13^{\prime} 47^{\prime \prime}$ & $80^{\circ} 17^{\prime} 54^{\prime \prime}$ & DBHYDRO \\
\hline S37A_R & Rainfall station ${ }^{3}$ & $26^{\circ} 12^{\prime} 21^{\prime \prime}$ & $80^{\circ} 07^{\prime} 56^{\prime \prime}$ & DBHYDRO \\
\hline S36_R & Rainfall station ${ }^{3}$ & $26^{\circ} 10^{\prime} 24^{\prime \prime}$ & $80^{\circ} 10^{\prime} 42^{\prime \prime}$ & DBHYDRO \\
\hline S33_R & Rainfall station ${ }^{3}$ & $26^{\circ} 08^{\prime} 08^{\prime \prime}$ & $80^{\circ} 11^{\prime} 27^{\prime \prime}$ & DBHYDRO \\
\hline S34_R & Rainfall station ${ }^{3}$ & $26^{\circ} 09^{\prime} 01^{\prime \prime}$ & $80^{\circ} 26^{\prime} 32^{\prime \prime}$ & DBHYDRO \\
\hline FT. LAUD_R & Rainfall station ${ }^{3}$ & $26^{\circ} 03^{\prime} 49^{\prime \prime}$ & $80^{\circ} 15^{\prime} 34^{\prime \prime}$ & DBHYDRO \\
\hline MIRAMAR_R & Rainfall station ${ }^{3}$ & $26^{\circ} 01^{\prime} 01^{\prime \prime}$ & $80^{\circ} 30^{\prime} 59^{\prime \prime}$ & DBHYDRO \\
\hline ROTNWX & Rainfall station ${ }^{3}$ & $26^{\circ} 19^{\prime} 55^{\prime \prime}$ & $80^{\circ} 52^{\prime} 47^{\prime \prime}$ & DBHYDRO \\
\hline 3A-S_R & Rainfall station ${ }^{3}$ & $26^{\circ} 05^{\prime} 00^{\prime \prime}$ & $80^{\circ} 41^{\prime} 04^{\prime \prime}$ & DBHYDRO \\
\hline S20_R & Rainfall station ${ }^{3}$ & $25^{\circ} 22^{\prime} 01^{\prime \prime}$ & $80^{\circ} 22^{\prime} 35^{\prime \prime}$ & DBHYDRO \\
\hline SYLVA_G & Rainfall station ${ }^{3}$ & $25^{\circ} 46^{\prime} 01^{\prime \prime}$ & $80^{\circ} 16^{\prime} 59^{\prime \prime}$ & DBHYDRO \\
\hline HOMES.FS_R & Rainfall station ${ }^{3}$ & $25^{\circ} 28^{\prime} 39^{\prime \prime}$ & $80^{\circ} 26^{\prime} 54^{\prime \prime}$ & DBHYDRO \\
\hline S331W & Rainfall station ${ }^{3}$ & $25^{\circ} 36^{\prime} 39^{\prime \prime}$ & $80^{\circ} 30^{\prime} 35^{\prime \prime}$ & DBHYDRO \\
\hline S123 & Rainfall station ${ }^{3}$ & $25^{\circ} 36^{\prime} 37^{\prime \prime}$ & $80^{\circ} 18^{\prime} 28^{\prime \prime}$ & DBHYDRO \\
\hline S174_R & Rainfall station ${ }^{3}$ & $25^{\circ} 29^{\prime} 01^{\prime \prime}$ & $80^{\circ} 33^{\prime} 48^{\prime \prime}$ & DBHYDRO \\
\hline S177_R & Rainfall station ${ }^{3}$ & $25^{\circ} 24^{\prime} 10^{\prime \prime}$ & $80^{\circ} 33^{\prime} 30^{\prime \prime}$ & DBHYDRO \\
\hline TAMIAMI_CN & Rainfall station ${ }^{3}$ & $25^{\circ} 46^{\prime} 01^{\prime \prime}$ & $80^{\circ} 40^{\prime} 59^{\prime \prime}$ & DBHYDRO \\
\hline TAMI AIR_R & Rainfall station ${ }^{3}$ & $25^{\circ} 38^{\prime} 28^{\prime \prime}$ & $80^{\circ} 25^{\prime} 36^{\prime \prime}$ & DBHYDRO \\
\hline PERRINE_R & Rainfall station ${ }^{3}$ & $25^{\circ} 36^{\prime} 01^{\prime \prime}$ & $80^{\circ} 20^{\prime} 59^{\prime \prime}$ & DBHYDRO \\
\hline MIAMI.FS_R & Rainfall station ${ }^{3}$ & $25^{\circ} 49^{\prime} 37^{\prime \prime}$ & $80^{\circ} 20^{\prime} 39^{\prime \prime}$ & DBHYDRO \\
\hline
\end{tabular}




\begin{tabular}{|c|c|c|c|c|}
\hline Station name & Station type & Latitude & Longitude & Data source \\
\hline MIAMI.AP_R & Rainfall station ${ }^{3}$ & $25^{\circ} 49^{\prime} 01^{\prime \prime}$ & $80^{\circ} 16^{\prime} 59^{\prime \prime}$ & DBHYDRO \\
\hline N DADE_R & Rainfall station ${ }^{3}$ & $25^{\circ} 48^{\prime} 00^{\prime \prime}$ & $80^{\circ} 14^{\prime} 25^{\prime \prime}$ & DBHYDRO \\
\hline S27_R & Rainfall station ${ }^{3}$ & $25^{\circ} 50^{\prime} 55^{\prime \prime}$ & $80^{\circ} 11^{\prime} 20^{\prime \prime}$ & DBHYDRO \\
\hline S29_R & Rainfall station ${ }^{3}$ & $25^{\circ} 55^{\prime} 42^{\prime \prime}$ & $80^{\circ} 09^{\prime} 03^{\prime \prime}$ & DBHYDRO \\
\hline MIAMI 2_R & Rainfall station ${ }^{3}$ & $25^{\circ} 47^{\prime} 00^{\prime \prime}$ & $80^{\circ} 08^{\prime} 00^{\prime \prime}$ & DBHYDRO \\
\hline S18C_R & Rainfall station ${ }^{3}$ & $25^{\circ} 19^{\prime} 50^{\prime \prime}$ & $80^{\circ} 31^{\prime} 30^{\prime \prime}$ & DBHYDRO \\
\hline S332_R & Rainfall station ${ }^{3}$ & $25^{\circ} 25^{\prime} 18^{\prime \prime}$ & $80^{\circ} 35^{\prime} 23^{\prime \prime}$ & DBHYDRO \\
\hline S338_R & Rainfall station ${ }^{3}$ & $25^{\circ} 39^{\prime} 38^{\prime \prime}$ & $80^{\circ} 28^{\prime} 49^{\prime \prime}$ & DBHYDRO \\
\hline S331_R & Rainfall station ${ }^{3}$ & $25^{\circ} 36^{\prime} 39^{\prime \prime}$ & $80^{\circ} 30^{\prime} 35^{\prime \prime}$ & DBHYDRO \\
\hline S28Z_R & Rainfall station ${ }^{3}$ & $25^{\circ} 54^{\prime} 48^{\prime \prime}$ & $80^{\circ} 17^{\prime} 35^{\prime \prime}$ & DBHYDRO \\
\hline S29Z_R & Rainfall station ${ }^{3}$ & $25^{\circ} 57^{\prime} 43^{\prime \prime}$ & $80^{\circ} 15^{\prime} 52^{\prime \prime}$ & DBHYDRO \\
\hline S26_R & Rainfall station ${ }^{3}$ & $25^{\circ} 48^{\prime} 29^{\prime \prime}$ & $80^{\circ} 15^{\prime} 39^{\prime \prime}$ & DBHYDRO \\
\hline S21_R & Rainfall station ${ }^{3}$ & $25^{\circ} 32^{\prime} 35^{\prime \prime}$ & $80^{\circ} 19^{\prime} 51^{\prime \prime}$ & DBHYDRO \\
\hline S21A_R & Rainfall station ${ }^{3}$ & $25^{\circ} 31^{\prime} 09^{\prime \prime}$ & $80^{\circ} 20^{\prime} 46^{\prime \prime}$ & DBHYDRO \\
\hline S20G_R & Rainfall station ${ }^{3}$ & $25^{\circ} 29^{\prime} 21^{\prime \prime}$ & $80^{\circ} 20^{\prime} 50^{\prime \prime}$ & DBHYDRO \\
\hline S20F_R & Rainfall station ${ }^{3}$ & $25^{\circ} 27^{\prime} 46^{\prime \prime}$ & $80^{\circ} 20^{\prime} 51^{\prime \prime}$ & DBHYDRO \\
\hline HOMES.FS_R & Rainfall station ${ }^{3}$ & $25^{\circ} 28^{\prime} 39^{\prime \prime}$ & $80^{\circ} 26^{\prime} 54^{\prime \prime}$ & DBHYDRO \\
\hline HOMES.AFB & Rainfall station ${ }^{3}$ & $25^{\circ} 29^{\prime} 01^{\prime \prime}$ & $80^{\circ} 23^{\prime} 00^{\prime \prime}$ & DBHYDRO \\
\hline SWEETWATER & Rainfall station ${ }^{3}$ & $25^{\circ} 53^{\prime} 01^{\prime \prime}$ & $80^{\circ} 35^{\prime} 59^{\prime \prime}$ & DBHYDRO \\
\hline COOPER_R & Rainfall station ${ }^{3}$ & $25^{\circ} 49^{\prime} 01^{\prime \prime}$ & $80^{\circ} 42^{\prime} 59^{\prime \prime}$ & DBHYDRO \\
\hline CHEKIKA EV & Rainfall station ${ }^{3}$ & $25^{\circ} 42^{\prime} 01^{\prime \prime}$ & $80^{\circ} 37^{\prime} 59^{\prime \prime}$ & DBHYDRO \\
\hline S336_R & Rainfall station ${ }^{3}$ & $25^{\circ} 45^{\prime} 41^{\prime \prime}$ & $80^{\circ} 29^{\prime} 48^{\prime \prime}$ & DBHYDRO \\
\hline MIAMI.FS_R & Rainfall station ${ }^{3}$ & $25^{\circ} 49^{\prime} 37^{\prime \prime}$ & $80^{\circ} 20^{\prime} 39^{\prime \prime}$ & DBHYDRO \\
\hline MIAMI.FS_R & Rainfall station ${ }^{3}$ & $25^{\circ} 49^{\prime} 37^{\prime \prime}$ & $80^{\circ} 20^{\prime} 39^{\prime \prime}$ & DBHYDRO \\
\hline S20F_R & Rainfall station ${ }^{3}$ & $25^{\circ} 27^{\prime} 46^{\prime \prime}$ & $80^{\circ} 20^{\prime} 51^{\prime \prime}$ & DBHYDRO \\
\hline S18C_R & Rainfall station ${ }^{3}$ & $25^{\circ} 19^{\prime} 50^{\prime \prime}$ & $80^{\circ} 31^{\prime} 30^{\prime \prime}$ & DBHYDRO \\
\hline S331_R & Rainfall station ${ }^{3}$ & $25^{\circ} 36^{\prime} 39^{\prime \prime}$ & $80^{\circ} 30^{\prime} 35^{\prime \prime}$ & DBHYDRO \\
\hline S332_R & Rainfall station ${ }^{3}$ & $25^{\circ} 25^{\prime} 18^{\prime \prime}$ & $80^{\circ} 35^{\prime} 23^{\prime \prime}$ & DBHYDRO \\
\hline NP-P36 & Rainfall station ${ }^{3}$ & $25^{\circ} 31^{\prime} 43^{\prime \prime}$ & $80^{\circ} 47^{\prime} 44^{\prime \prime}$ & DBHYDRO \\
\hline NP-P38 & Rainfall station ${ }^{3}$ & $25^{\circ} 22^{\prime} 15^{\prime \prime}$ & $80^{\circ} 50^{\prime} 00^{\prime \prime}$ & DBHYDRO \\
\hline
\end{tabular}




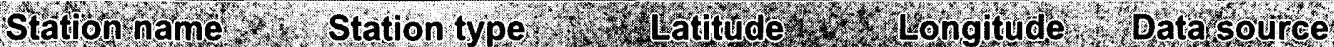

\begin{tabular}{|c|c|c|c|c|}
\hline NP-203 & Rainfall station ${ }^{3}$ & $25^{\circ} 37^{\prime} 26^{\prime \prime}$ & $80^{\circ} 44^{\prime} 21^{\prime \prime}$ & DBHYDRO \\
\hline NP-201 & Rainfall station ${ }^{3}$ & $25^{\circ} 43^{\prime} 06^{\prime \prime}$ & $80^{\circ} 43^{\prime} 32^{\prime \prime}$ & DBHYDRO \\
\hline S12D_R & Rainfall station ${ }^{3}$ & $25^{\circ} 45^{\prime} 44^{\prime \prime}$ & $80^{\circ} 40^{\prime} 53^{\prime \prime}$ & DBHYDRO \\
\hline TAMITR40_R & Rainfall station ${ }^{3}$ & $25^{\circ} 45^{\prime} 37^{\prime \prime}$ & $80^{\circ} 49^{\prime} 29^{\prime \prime}$ & DBHYDRO \\
\hline MIAMI BE_R & Rainfall station ${ }^{3}$ & $25^{\circ} 46^{\prime} 49^{\prime \prime}$ & $80^{\circ} 07^{\prime} 48^{\prime \prime}$ & DBHYDRO \\
\hline MIAMI.AP_R & Rainfall station ${ }^{3}$ & $25^{\circ} 49^{\prime} 01^{\prime \prime}$ & $80^{\circ} 16^{\prime} 59^{\prime \prime}$ & DBHYDRO \\
\hline HIALEAH_R & Rainfall station ${ }^{3}$ & $25^{\circ} 49^{\prime} 39^{\prime \prime}$ & $80^{\circ} 17^{\prime} 09^{\prime \prime}$ & DBHYDRO \\
\hline ROYAL PA_R & Rainfall station ${ }^{3}$ & $25^{\circ} 23^{\prime} 11^{\prime \prime}$ & $80^{\circ} 35^{\prime} 38^{\prime \prime}$ & DBHYDRO \\
\hline NP-EPR & Rainfall station ${ }^{3}$ & $25^{\circ} 16^{\prime} 10^{\prime \prime}$ & $80^{\circ} 30^{\prime} 16^{\prime \prime}$ & DBHYDRO \\
\hline JBTS & Rainfall station ${ }^{3}$ & $25^{\circ} 13^{\prime} 28^{\prime \prime}$ & $80^{\circ} 32^{\prime} 24^{\prime \prime}$ & DBHYDRO \\
\hline NP-EV8 & Rainfall station ${ }^{3}$ & $25^{\circ} 20^{\prime} 47^{\prime \prime}$ & $80^{\circ} 28^{\prime} 43^{\prime \prime}$ & DBHYDRO \\
\hline TPTS & Rainfall station ${ }^{3}$ & $25^{\circ} 12^{\prime} 23^{\prime \prime}$ & $80^{\circ} 22^{\prime} 29^{\prime \prime}$ & DBHYDRO \\
\hline MDTS & Rainfall station ${ }^{3}$ & $25^{\circ} 16^{\prime} 43^{\prime \prime}$ & $80^{\circ} 23^{\prime} 42^{\prime \prime}$ & DBHYDRO \\
\hline S331_R & Rainfall station ${ }^{3}$ & $25^{\circ} 36^{\prime} 39^{\prime \prime}$ & $80^{\circ} 30^{\prime} 35^{\prime \prime}$ & DBHYDRO \\
\hline NP-205 & Rainfall station ${ }^{3}$ & $25^{\circ} 41^{\prime} 21^{\prime \prime}$ & $80^{\circ} 50^{\prime} 56^{\prime \prime}$ & DBHYDRO \\
\hline NP-202 & Rainfall station ${ }^{3}$ & $25^{\circ} 39^{\prime} 41^{\prime \prime}$ & $80^{\circ} 42^{\prime} 44^{\prime \prime}$ & DBHYDRO \\
\hline NP-P33 & Rainfall station ${ }^{3}$ & $25^{\circ} 36^{\prime} 31^{\prime \prime}$ & $80^{\circ} 41^{\prime} 29^{\prime \prime}$ & DBHYDRO \\
\hline NP-206 & Rainfall station ${ }^{3}$ & $25^{\circ} 32^{\prime} 43^{\prime \prime}$ & $80^{\circ} 40^{\prime} 21^{\prime \prime}$ & DBHYDRO \\
\hline NP-127 & Rainfall station ${ }^{3}$ & $25^{\circ} 21^{\prime} 16^{\prime \prime}$ & $80^{\circ} 36^{\prime} 22^{\prime \prime}$ & DBHYDRO \\
\hline NP-N10 & Rainfall station ${ }^{3}$ & $25^{\circ} 27^{\prime} 43^{\prime \prime}$ & $80^{\circ} 36^{\prime} 18^{\prime \prime}$ & DBHYDRO \\
\hline NP-A13 & Rainfall station ${ }^{3}$ & $25^{\circ} 29^{\prime} 56^{\prime \prime}$ & $80^{\circ} 42^{\prime} 45^{\prime \prime}$ & DBHYDRO \\
\hline NP-311 & Rainfall station ${ }^{3}$ & $25^{\circ} 26^{\prime} 51^{\prime \prime}$ & $80^{\circ} 37^{\prime} 34^{\prime \prime}$ & DBHYDRO \\
\hline NP-P35 & Rainfall station ${ }^{3}$ & $25^{\circ} 27^{\prime} 40^{\prime \prime}$ & $80^{\circ} 51^{\prime} 52^{\prime \prime}$ & DBHYDRO \\
\hline NP-P37 & Rainfall station ${ }^{3}$ & $25^{\circ} 17^{\prime} 09^{\prime \prime}$ & $80^{\circ} 41^{\prime} 18^{\prime \prime}$ & DBHYDRO \\
\hline NP-ROB & Rainfall station ${ }^{3}$ & $25^{\circ} 26^{\prime} 27^{\prime \prime}$ & $80^{\circ} 33^{\prime} 07^{\prime \prime}$ & DBHYDRO \\
\hline NP-RPL & Rainfall station ${ }^{3}$ & $25^{\circ} 23^{\prime} 11^{\prime \prime}$ & $80^{\circ} 35^{\prime} 37^{\prime \prime}$ & DBHYDRO \\
\hline NP-FMB & Rainfall station ${ }^{3}$ & $25^{\circ} 45^{\prime} 32^{\prime \prime}$ & $80^{\circ} 49^{\prime} 41^{\prime \prime}$ & DBHYDRO \\
\hline NP-CHP & Rainfall station ${ }^{3}$ & $25^{\circ} 13^{\prime} 45^{\prime \prime}$ & $80^{\circ} 42^{\prime} 14^{\prime \prime}$ & DBHYDRO \\
\hline NP-RG1 & Rainfall station ${ }^{3}$ & $25^{\circ} 34^{\prime} 58^{\prime \prime}$ & $80^{\circ} 36^{\prime} 28^{\prime \prime}$ & DBHYDRO \\
\hline NP-RCR & Rainfall station ${ }^{3}$ & $25^{\circ} 23^{\prime} 25^{\prime \prime}$ & $80^{\circ} 40^{\prime} 50^{\prime \prime}$ & DBHYDRO \\
\hline
\end{tabular}




\begin{tabular}{|c|c|c|c|c|}
\hline Station name & Station type & Latitude & Longitude & Data source \\
\hline NP-IFS & Rainfall station ${ }^{3}$ & $25^{\circ} 30^{\prime} 36^{\prime \prime}$ & $80^{\circ} 29^{\prime} 59^{\prime \prime}$ & DBHYDRO \\
\hline PERRINE 4W & Rainfall station ${ }^{3}$ & $25^{\circ} 35^{\prime} 01^{\prime \prime}$ & $80^{\circ} 25^{\prime} 59^{\prime \prime}$ & DBHYDRO \\
\hline HOMES.FS_R & Rainfall station ${ }^{3}$ & $25^{\circ} 28^{\prime} 39^{\prime \prime}$ & $80^{\circ} 26^{\prime} 54^{\prime \prime}$ & DBHYDRO \\
\hline S336_R & Rainfall station ${ }^{3}$ & $25^{\circ} 45^{\prime} 41^{\prime \prime}$ & $80^{\circ} 29^{\prime} 48^{\prime \prime}$ & DBHYDRO \\
\hline HIALEAH_W & Rainfall station ${ }^{3}$ & $25^{\circ} 52^{\prime} 01^{\prime \prime}$ & $80^{\circ} 28^{\prime} 59^{\prime \prime}$ & DBHYDRO \\
\hline NP-NE1 & Rainfall station ${ }^{3}$ & $25^{\circ} 41^{\prime} 31^{\prime \prime}$ & $80^{\circ} 38^{\prime} 05^{\prime \prime}$ & DBHYDRO \\
\hline S332_R & Rainfall station ${ }^{3}$ & $25^{\circ} 25^{\prime} 18^{\prime \prime}$ & $80^{\circ} 35^{\prime} 23^{\prime \prime}$ & DBHYDRO \\
\hline CHEKIKA_R & Rainfall station ${ }^{3}$ & $25^{\circ} 36^{\prime} 57^{\prime \prime}$ & $80^{\circ} 35^{\prime} 02^{\prime \prime}$ & DBHYDRO \\
\hline MIAMI.AP_R & Rainfall station ${ }^{3}$ & $25^{\circ} 49^{\prime} 01^{\prime \prime}$ & $80^{\circ} 16^{\prime} 59^{\prime \prime}$ & DBHYDRO \\
\hline PENNSUCO_R & Rainfall station ${ }^{3}$ & $25^{\circ} 55^{\prime} 30^{\prime \prime}$ & $80^{\circ} 27^{\prime} 06^{\prime \prime}$ & DBHYDRO \\
\hline TRAIL RG_R & Rainfall station ${ }^{3}$ & $25^{\circ} 46^{\prime} 01^{\prime \prime}$ & $80^{\circ} 28^{\prime} 59^{\prime \prime}$ & DBHYDRO \\
\hline HOMES.ES_R & Rainfall station ${ }^{3}$ & $25^{\circ} 30^{\prime} 31^{\prime \prime}$ & $80^{\circ} 29^{\prime} 59^{\prime \prime}$ & DBHYDRO \\
\hline NP-P35 & Rainfall station ${ }^{3}$ & $25^{\circ} 27^{\prime} 40^{\prime \prime}$ & $80^{\circ} 51^{\prime} 52^{\prime \prime}$ & DBHYDRO \\
\hline NP-206_R & Rainfall station ${ }^{3}$ & $25^{\circ} 32^{\prime} 43^{\prime \prime}$ & $80^{\circ} 40^{\prime} 21^{\prime \prime}$ & DBHYDRO \\
\hline NESRS1_R & Rainfall station ${ }^{3}$ & $25^{\circ} 41^{\prime} 51^{\prime \prime}$ & $80^{\circ} 38^{\prime} 04^{\prime \prime}$ & DBHYDRO \\
\hline ROCKDALE_R & Rainfall station ${ }^{3}$ & $25^{\circ} 25^{\prime} 51^{\prime \prime}$ & $80^{\circ} 34^{\prime} 47^{\prime \prime}$ & DBHYDRO \\
\hline NP-311 & Rainfall station ${ }^{3}$ & $25^{\circ} 26^{\prime} 51^{\prime \prime}$ & $80^{\circ} 37^{\prime} 34^{\prime \prime}$ & DBHYDRO \\
\hline ROCKDALG_R & Rainfall station ${ }^{3}$ & $25^{\circ} 33^{\prime} 06^{\prime \prime}$ & $80^{\circ} 28^{\prime} 11^{\prime \prime}$ & DBHYDRO \\
\hline MUD CRK_R & Rainfall station ${ }^{3}$ & $25^{\circ} 12^{\prime} 14^{\prime \prime}$ & $80^{\circ} 35^{\prime} 06^{\prime \prime}$ & DBHYDRO \\
\hline NP-P34 & Rainfall station ${ }^{3}$ & $25^{\circ} 36^{\prime} 31^{\prime \prime}$ & $80^{\circ} 55^{\prime} 29^{\prime \prime}$ & DBHYDRO \\
\hline NP-FLA & Rainfall station ${ }^{3}$ & $25^{\circ} 08^{\prime} 30^{\prime \prime}$ & $80^{\circ} 54^{\prime} 52^{\prime \prime}$ & DBHYDRO \\
\hline NP-OT3 & Rainfall station ${ }^{3}$ & $25^{\circ} 34^{\prime} 48^{\prime \prime}$ & $80^{\circ} 57^{\prime} 53^{\prime \prime}$ & DBHYDRO \\
\hline DUCK KEY & Rainfall station ${ }^{3}$ & $24^{\circ} 46^{\prime} 01^{\prime \prime}$ & $80^{\circ} 54^{\prime} 59^{\prime \prime}$ & DBHYDRO \\
\hline DUCK KEY_R & Rainfall station ${ }^{3}$ & $24^{\circ} 46^{\prime} 01^{\prime \prime}$ & $80^{\circ} 54^{\prime} 59^{\prime \prime}$ & DBHYDRO \\
\hline $2-17$ & Stage $^{4}$ & $26^{\circ} 17^{\prime} 12^{\prime \prime}$ & $80^{\circ} 24^{\prime} 39^{\prime \prime}$ & DBHYDRO \\
\hline $2-19$ & Stage $^{4}$ & $26^{\circ} 16^{\prime} 56^{\prime \prime}$ & $80^{\circ} 18^{\prime} 22^{\prime \prime}$ & DBHYDRO \\
\hline 2A-17_B & Stage $^{4}$ & $26^{\circ} 17^{\prime} 12^{\prime \prime}$ & $80^{\circ} 24^{\prime} 39^{\prime \prime}$ & DBHYDRO \\
\hline 2A-300_B & Stage $^{4}$ & $26^{\circ} 14^{\prime} 46^{\prime \prime}$ & $80^{\circ} 24^{\prime} 30^{\prime \prime}$ & DBHYDRO \\
\hline $2 \mathrm{~B}-\mathrm{Y}$ & Stage $^{4}$ & $26^{\circ} 07^{\prime} 46^{\prime \prime}$ & $80^{\circ} 21^{\prime} 58^{\prime \prime}$ & DBHYDRO \\
\hline $3-34$ & Stage $^{4}$ & $25^{\circ} 52^{\prime} 16^{\prime \prime}$ & $80^{\circ} 29^{\prime} 09^{\prime \prime}$ & DBHYDRO \\
\hline
\end{tabular}


3-62

3-63

3-64

3-65

3-69

3-71

3-76

3-99

3A-10_B

3A-11_B

3A-12_B

3A-28

3A-9_B

3A-NE_B

3A-NW_B

3A-S_B

3A-SW_B

3B-SE_B

C1

C11.1595

C11U27_O

C11U75_O

C13.UNIV

C2.74

C4.CORAL

C6.L30

C8.S28Z

C9.NW67

C9.S29Z

CA3AVG

$$
\text { Stage }^{4}
$$

Stage $^{4}$

Stage ${ }^{4}$

Stage $^{4}$

Stage $^{4}$

Stage $^{4}$

Stage ${ }^{4}$

Stage ${ }^{4}$

Stage $\mathrm{e}^{4}$

Stage ${ }^{4}$

Stage ${ }^{4}$

Stage ${ }^{4}$

Stage ${ }^{4}$

Stage ${ }^{4}$

Stage ${ }^{4}$

Stage ${ }^{4}$

Stage ${ }^{4}$

Stage ${ }^{4}$

Stage ${ }^{4}$

Stage $^{4}$

Stage $^{4}$

Stage $^{4}$

Stage ${ }^{4}$

Stage $^{4}$

Stage $^{4}$

Stage 4

Stage ${ }^{4}$

Stage ${ }^{4}$

Stage 4

Stage ${ }^{4}$ $26^{\circ} 10^{\prime} 29^{\prime \prime}$

$26^{\circ} 11^{\prime} 20^{\prime \prime}$

$25^{\circ} 58^{\prime} 32^{\prime \prime}$

$25^{\circ} 48^{\prime} 53^{\prime \prime}$

$25^{\circ} 53^{\prime} 01^{\prime \prime}$

$25^{\circ} 53^{\prime} 05^{\prime \prime}$

$26^{\circ} 00^{\prime} 28^{\prime \prime}$

$26^{\circ} 08^{\prime} 22^{\prime \prime}$

$26^{\circ} 16^{\prime} 45^{\prime \prime}$

$26^{\circ} 13^{\prime} 05^{\prime \prime}$

$26^{\circ} 10^{\prime} 08^{\prime \prime}$

$25^{\circ} 48^{\prime} 44^{\prime \prime}$

$26^{\circ} 07^{\prime} 22^{\prime \prime}$

$26^{\circ} 16^{\prime} 43^{\prime \prime}$

$26^{\circ} 17^{\prime} 08^{\prime \prime}$

$26^{\circ} 05^{\prime} 00^{\prime \prime}$

$25^{\circ} 59^{\prime} 23^{\prime \prime}$

$25^{\circ} 47^{\prime} 16^{\prime \prime}$

$25^{\circ} 32^{\prime} 44^{\prime \prime}$

$26^{\circ} 05^{\prime} 03^{\prime \prime}$

$26^{\circ} 03^{\prime} 40^{\prime \prime}$

$26^{\circ} 03^{\prime} 47^{\prime \prime}$

$26^{\circ} 10^{\prime} 01^{\prime \prime}$

$25^{\circ} 50^{\prime} 27^{\prime \prime}$

$25^{\circ} 45^{\prime} 44^{\prime \prime}$

$25^{\circ} 56^{\prime} 29^{\prime \prime}$

$25^{\circ} 54^{\prime} 48^{\prime \prime}$

$25^{\circ} 57^{\prime} 51^{\prime \prime}$

$25^{\circ} 57^{\prime} 43^{\prime \prime}$

$25^{\circ} 48^{\prime} 44^{\prime \prime}$ $80^{\circ} 45^{\prime} 04^{\prime \prime}$

$80^{\circ} 31^{\prime} 51^{\prime \prime}$

$80^{\circ} 40^{\prime} 09^{\prime \prime}$

$80^{\circ} 43^{\prime} 11^{\prime \prime}$

$80^{\circ} 36^{\prime} 59^{\prime \prime}$

$80^{\circ} 33^{\prime} 24^{\prime \prime}$

$80^{\circ} 28^{\prime} 57^{\prime \prime}$

$80^{\circ} 22^{\prime} 01^{\prime \prime}$

$80^{\circ} 44^{\prime} 24^{\prime \prime}$

$80^{\circ} 44^{\prime} 38^{\prime \prime}$

$80^{\circ} 40^{\prime} 33^{\prime \prime}$

$80^{\circ} 43^{\prime} 19^{\prime \prime}$

$80^{\circ} 38^{\prime} 52^{\prime \prime}$

$80^{\circ} 36^{\prime} 18^{\prime \prime}$

$80^{\circ} 46^{\prime} 33^{\prime \prime}$

$80^{\circ} 41^{\prime} 04^{\prime \prime}$

$80^{\circ} 50^{\prime} 10^{\prime \prime}$

$80^{\circ} 29^{\prime} 59^{\prime \prime}$

$80^{\circ} 19^{\prime} 54^{\prime \prime}$

$80^{\circ} 11^{\prime} 07^{\prime \prime}$

DBHYDRO

$80^{\circ} 25^{\prime} 53^{\prime \prime}$

DBHYDRO

$80^{\circ} 21^{\prime} 48^{\prime \prime}$

DBHYDRO

$80^{\circ} 15^{\prime} 59^{\prime \prime}$

DBHYDRO

$80^{\circ} 23^{\prime} 12^{\prime \prime}$

DBHYDRO

$80^{\circ} 19^{\prime} 47^{\prime \prime}$

DBHYDRO

$80^{\circ} 26^{\prime} 22^{\prime \prime}$

DBHYDRO

$80^{\circ} 17^{\prime} 35^{\prime \prime}$

DBHYDRO

$80^{\circ} 18^{\prime} 39^{\prime \prime}$

DBHYDRO

$80^{\circ} 15^{\prime} 52^{\prime \prime}$

DBHYDRO

$80^{\circ} 43^{\prime} 19^{\prime \prime}$

DBHYDRO 
G119_H

G123P_H

G123P_T

G-3273

G54_H

G54_T

G57_H

G57_T

G58_H

G58_T

G69_H

G72_H

G86N_H

G88_H

G88_T

G93_T

JBTS

L28-1

L28-2

L29

L31.EXT1

L31.EXT2

L31.EXT3

L31E_H

L31E_T

L67E

L67E.S

L67EX.E_B

L67EX.W

MBTS
Stage $^{4}$

Stage ${ }^{4}$

Stage ${ }^{4}$

Stage ${ }^{4}$

Stage 4

Stage ${ }^{4}$

Stage ${ }^{4}$

Stage ${ }^{4}$

Stage ${ }^{4}$

Stage ${ }^{4}$

Stage $^{4}$

Stage ${ }^{4}$

Stage 4

Stage ${ }^{4}$

Stage ${ }^{4}$

Stage ${ }^{4}$

Stage 4

Stage 4

Stage ${ }^{4}$

Stage $^{4}$

Stage ${ }^{4}$

Stage $^{4}$

Stage $^{4}$

Stage $^{4}$

Stage $^{4}$

Stage $^{4}$

Stage $^{4}$

Stage $^{4}$

Stage $^{4}$

Stage ${ }^{4}$ $25^{\circ} 45^{\prime} 42^{\prime \prime}$

$26^{\circ} 09^{\prime} 01^{\prime \prime}$

$26^{\circ} 09^{\prime} 01^{\prime \prime}$

$25^{\circ} 37^{\prime} 49^{\prime \prime}$

$26^{\circ} 05^{\prime} 40^{\prime \prime}$

$26^{\circ} 05^{\prime} 40^{\prime \prime}$

$26^{\circ} 13^{\prime} 52^{\prime \prime}$

$26^{\circ} 13^{\prime} 52^{\prime \prime}$

$25^{\circ} 54^{\prime} 00^{\prime \prime}$

$25^{\circ} 54^{\prime} 00^{\prime \prime}$

$25^{\circ} 45^{\prime} 41^{\prime \prime}$

$25^{\circ} 52^{\prime} 09^{\prime \prime}$

$26^{\circ} 03^{\prime} 42^{\prime \prime}$

$26^{\circ} 19^{\prime} 53^{\prime \prime}$

$26^{\circ} 19^{\prime} 53^{\prime \prime}$

$25^{\circ} 44^{\prime} 18^{\prime \prime}$

$25^{\circ} 13^{\prime} 28^{\prime \prime}$

$26^{\circ} 05^{\prime} 37^{\prime \prime}$

$26^{\circ} 05^{\prime} 37^{\prime \prime}$

$25^{\circ} 45^{\prime} 41^{\prime \prime}$

$25^{\circ} 44^{\prime} 48^{\prime \prime}$

$25^{\circ} 43^{\prime} 55^{\prime \prime}$

$25^{\circ} 43^{\prime} 02^{\prime \prime}$

$25^{\circ} 28^{\prime} 24^{\prime \prime}$

$25^{\circ} 28^{\prime} 24^{\prime \prime}$

$25^{\circ} 39^{\prime} 55^{\prime \prime}$

$25^{\circ} 37^{\prime} 36^{\prime \prime}$

$25^{\circ} 41^{\prime} 01^{\prime \prime}$

$25^{\circ} 41^{\prime} 01^{\prime \prime}$

$25^{\circ} 15^{\prime} 26^{\prime \prime}$ $80^{\circ} 28^{\prime} 37^{\prime \prime}$

$80^{\circ} 26^{\prime} 32^{\prime \prime}$

$80^{\circ} 26^{\prime} 32^{\prime \prime}$

$80^{\circ} 34^{\prime} 33^{\prime \prime}$

$80^{\circ} 13^{\prime} 49^{\prime \prime}$

$80^{\circ} 13^{\prime} 49^{\prime \prime}$

$80^{\circ} 07^{\prime} 27^{\prime \prime}$

$80^{\circ} 07^{\prime} 27^{\prime \prime}$

$80^{\circ} 09^{\prime} 43^{\prime \prime}$

$80^{\circ} 09^{\prime} 43^{\prime \prime}$

$80^{\circ} 33^{\prime} 41^{\prime \prime}$

$80^{\circ} 20^{\prime} 21^{\prime \prime}$

$80^{\circ} 26^{\prime} 04^{\prime \prime}$

$80^{\circ} 52^{\prime} 50^{\prime \prime}$

$80^{\circ} 52^{\prime} 50^{\prime \prime}$

$80^{\circ} 17^{\prime} 12^{\prime \prime}$

$80^{\circ} 32^{\prime} 24^{\prime \prime}$

$80^{\circ} 50^{\prime} 35^{\prime \prime}$

$80^{\circ} 50^{\prime} 06^{\prime \prime}$

$80^{\circ} 37^{\prime} 41^{\prime \prime}$

$80^{\circ} 29^{\prime} 51^{\prime \prime}$

$80^{\circ} 29^{\prime} 51^{\prime \prime}$

$80^{\circ} 29^{\prime} 51^{\prime \prime}$

$80^{\circ} 20^{\prime} 48^{\prime \prime}$

$80^{\circ} 20^{\prime} 48^{\prime \prime}$

$80^{\circ} 40^{\prime} 23^{\prime \prime}$

$80^{\circ} 40^{\prime} 20^{\prime \prime}$

$80^{\circ} 40^{\prime} 21^{\prime \prime}$

$80^{\circ} 40^{\prime} 23^{\prime \prime}$

$80^{\circ} 25^{\prime} 20^{\prime \prime}$
DBHYDRO

DBHYDRO

DBHYDRO

DBHYDRO

DBHYDRO

DBHYDRO

DBHYDRO

DBHYDRO

DBHYDRO

DBHYDRO

DBHYDRO

DBHYDRO

DBHYDRO

DBHYDRO

DBHYDRO

DBHYDRO

DBHYDRO

DBHYDRO

DBHYDRO

DBHYDRO

DBHYDRO

DBHYDRO

DBHYDRO

DBHYDRO

DBHYDRO

DBHYDRO

DBHYDRO

DBHYDRO

DBHYDRO

DBHYDRO 


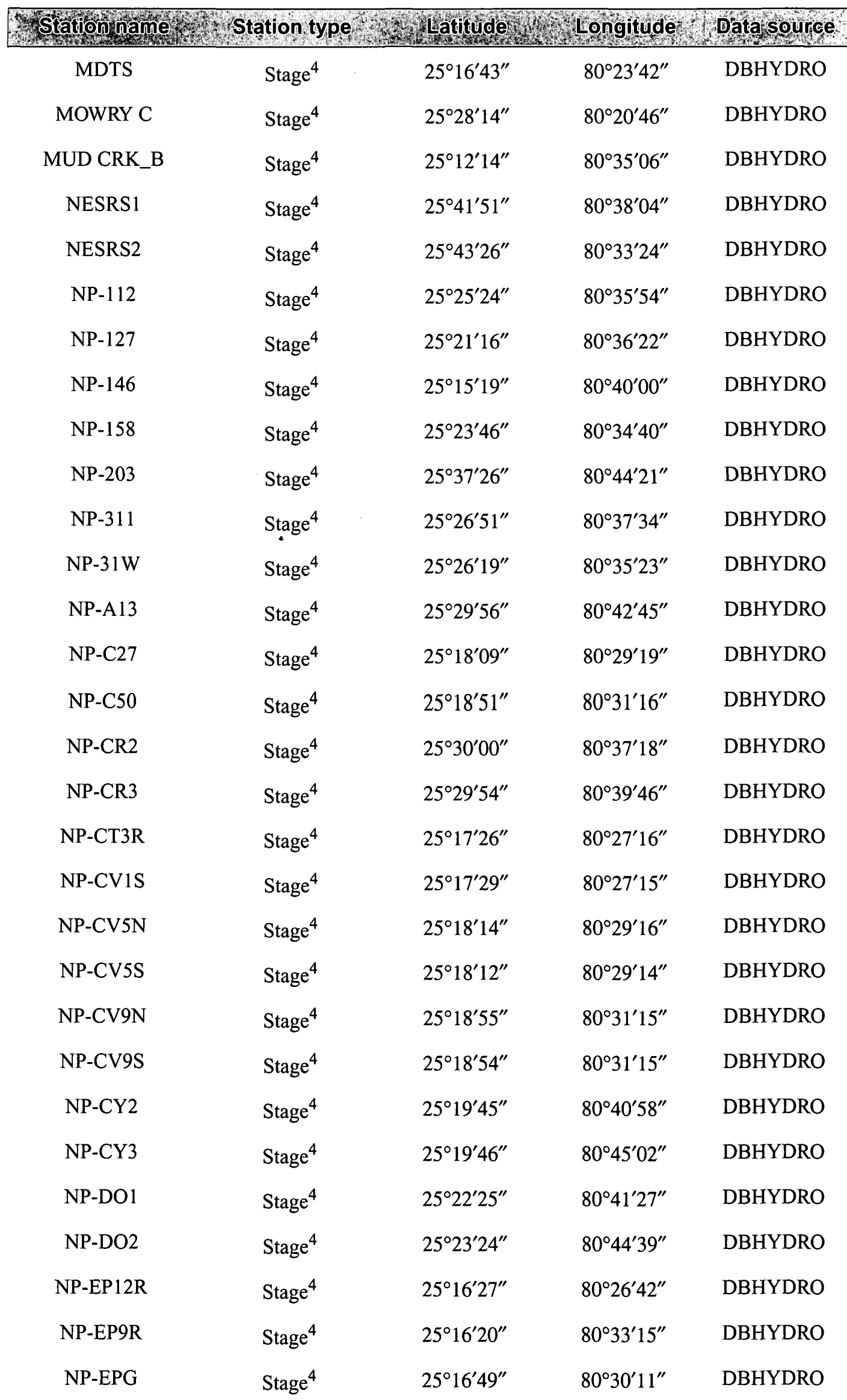




\section{Station name Station type W/ Latitude : Longlitude : Data source}

\begin{tabular}{|c|c|c|c|c|}
\hline NP-EPS & Stage $^{4}$ & $25^{\circ} 16^{\prime} 49^{\prime \prime}$ & $80^{\circ} 30^{\prime} 11^{\prime \prime}$ & DBHYDRO \\
\hline NP-EV6 & Stage $^{4}$ & $25^{\circ} 17^{\prime} 54^{\prime \prime}$ & $80^{\circ} 30^{\prime} 42^{\prime \prime}$ & DBHYDRO \\
\hline NP-EV7 & Stage $^{4}$ & $25^{\circ} 18^{\prime} 36^{\prime \prime}$ & $80^{\circ} 32^{\prime} 33^{\prime \prime}$ & DBHYDRO \\
\hline NP-EV8 & Stage ${ }^{4}$ & $25^{\circ} 20^{\prime} 47^{\prime \prime}$ & $80^{\circ} 28^{\prime} 43^{\prime \prime}$ & DBHYDRO \\
\hline NP-N10 & Stage $^{4}$ & $25^{\circ} 27^{\prime} 43^{\prime \prime}$ & $80^{\circ} 36^{\prime} 18^{\prime \prime}$ & DBHYDRO \\
\hline NP-N14 & Stage $^{4}$ & $25^{\circ} 25^{\prime} 04^{\prime \prime}$ & $80^{\circ} 38^{\prime} 20^{\prime \prime}$ & DBHYDRO \\
\hline NP-NMP & Stage $^{4}$ & $25^{\circ} 15^{\prime} 14^{\prime \prime}$ & $80^{\circ} 47^{\prime} 54^{\prime \prime}$ & DBHYDRO \\
\hline NP-NTS1 & Stage $^{4}$ & $25^{\circ} 26^{\prime} 17^{\prime \prime}$ & $80^{\circ} 35^{\prime} 34^{\prime \prime}$ & DBHYDRO \\
\hline NP-NTS3 & Stage $^{4}$ & $25^{\circ} 26^{\prime} 17^{\prime \prime}$ & $80^{\circ} 35^{\prime} 59^{\prime \prime}$ & DBHYDRO \\
\hline NP-P33 & Stage $^{4}$ & $25^{\circ} 36^{\prime} 31^{\prime \prime}$ & $80^{\circ} 41^{\prime} 29^{\prime \prime}$ & DBHYDRO \\
\hline NP-P35 & Stage $^{4}$ & $25^{\circ} 27^{\prime} 40^{\prime \prime}$ & $80^{\circ} 51^{\prime} 52^{\prime \prime}$ & DBHYDRO \\
\hline NP-P36 & Stage $^{4}$ & $25^{\circ} 31^{\prime} 43^{\prime \prime}$ & $80^{\circ} 47^{\prime} 44^{\prime \prime}$ & DBHYDRO \\
\hline NP-P37 & Stage $^{4}$ & $25^{\circ} 17^{\prime} 09^{\prime \prime}$ & $80^{\circ} 41^{\prime} 18^{\prime \prime}$ & DBHYDRO \\
\hline NP-P38 & Stage $^{4}$ & $25^{\circ} 22^{\prime} 15^{\prime \prime}$ & $80^{\circ} 50^{\prime} 00^{\prime \prime}$ & DBHYDRO \\
\hline NP-P44 & Stage $^{4}$ & $25^{\circ} 25^{\prime} 54^{\prime \prime}$ & $80^{\circ} 43^{\prime} 17^{\prime \prime}$ & DBHYDRO \\
\hline NP-P46 & Stage $^{4}$ & $25^{\circ} 19^{\prime} 11^{\prime \prime}$ & $80^{\circ} 47^{\prime} 45^{\prime \prime}$ & DBHYDRO \\
\hline NP-P62 & Stage $^{4}$ & $25^{\circ} 26^{\prime} 23^{\prime \prime}$ & $80^{\circ} 46^{\prime} 58^{\prime \prime}$ & DBHYDRO \\
\hline NP-P67 & Stage $^{4}$ & $25^{\circ} 19^{\prime} 51^{\prime \prime}$ & $80^{\circ} 39^{\prime} 01^{\prime \prime}$ & DBHYDRO \\
\hline NP-P72 & Stage $^{4}$ & $25^{\circ} 23^{\prime} 46^{\prime \prime}$ & $80^{\circ} 42^{\prime} 11^{\prime \prime}$ & DBHYDRO \\
\hline NP-RG1 & Stage $^{4}$ & $25^{\circ} 34^{\prime} 58^{\prime \prime}$ & $80^{\circ} 36^{\prime} 28^{\prime \prime}$ & DBHYDRO \\
\hline NP-RG2 & Stage $^{4}$ & $25^{\circ} 32^{\prime} 39^{\prime \prime}$ & $80^{\circ} 36^{\prime} 21^{\prime \prime}$ & DBHYDRO \\
\hline NP-ROB & Stage $^{4}$ & $25^{\circ} 26^{\prime} 27^{\prime \prime}$ & $80^{\circ} 33^{\prime} 07^{\prime \prime}$ & DBHYDRO \\
\hline NP-SP1 & Stage $e^{4}$ & $25^{\circ} 23^{\prime} 25^{\prime \prime}$ & $80^{\circ} 47^{\prime} 50^{\prime \prime}$ & DBHYDRO \\
\hline NP-TMC & Stage $^{4}$ & $25^{\circ} 36^{\prime} 56^{\prime \prime}$ & $80^{\circ} 52^{\prime} 20^{\prime \prime}$ & DBHYDRO \\
\hline NP-TSB & Stage $^{4}$ & $25^{\circ} 24^{\prime} 06^{\prime \prime}$ & $80^{\circ} 36^{\prime} 24^{\prime \prime}$ & DBHYDRO \\
\hline NP-TSH & Stage $^{4}$ & $25^{\circ} 18^{\prime} 45^{\prime \prime}$ & $80^{\circ} 37^{\prime} 50^{\prime \prime}$ & DBHYDRO \\
\hline POND AP1 & Stage $^{4}$ & $26^{\circ} 04^{\prime} 39^{\prime \prime}$ & $80^{\circ} 11^{\prime} 34^{\prime \prime}$ & DBHYDRO \\
\hline POND APP & Stage $^{4}$ & $26^{\circ} 04^{\prime} 58^{\prime \prime}$ & $80^{\circ} 11^{\prime} 41^{\prime \prime}$ & DBHYDRO \\
\hline S11A_H & Stage $^{4}$ & $26^{\circ} 10^{\prime} 37^{\prime \prime}$ & $80^{\circ} 26^{\prime} 55^{\prime \prime}$ & DBHYDRO \\
\hline S11A_T & Stage $^{4}$ & $26^{\circ} 10^{\prime} 37^{\prime \prime}$ & $80^{\circ} 26^{\prime} 55^{\prime \prime}$ & DBHYDRO \\
\hline
\end{tabular}




\begin{tabular}{|c|c|c|c|c|}
\hline Station name & Station type & Latitude & Longitude & Data source \\
\hline S11B_H & Stage $^{4}$ & $26^{\circ} 12^{\prime} 09^{\prime \prime}$ & $80^{\circ} 27^{\prime} 15^{\prime \prime}$ & DBHYDRO \\
\hline S11B_T & Stage $^{4}$ & $26^{\circ} 12^{\prime} 09^{\prime \prime}$ & $80^{\circ} 27^{\prime} 15^{\prime \prime}$ & DBHYDRO \\
\hline S11C_H & Stage $^{4}$ & $26^{\circ} 13^{\prime} 46^{\prime \prime}$ & $80^{\circ} 27^{\prime} 36^{\prime \prime}$ & DBHYDRO \\
\hline $\mathrm{S} 11 \mathrm{C}_{-} \mathrm{T}$ & Stage $^{4}$ & $26^{\circ} 13^{\prime} 46^{\prime \prime}$ & $80^{\circ} 27^{\prime} 36^{\prime \prime}$ & DBHYDRO \\
\hline S12_H & Stage $^{4}$ & $25^{\circ} 45^{\prime} 43^{\prime \prime}$ & $80^{\circ} 43^{\prime} 33^{\prime \prime}$ & DBHYDRO \\
\hline S120_H & Stage $^{4}$ & $25^{\circ} 40^{\prime} 15^{\prime \prime}$ & $80^{\circ} 19^{\prime} 17^{\prime \prime}$ & DBHYDRO \\
\hline S121_H & Stage $^{4}$ & $25^{\circ} 41^{\prime} 13^{\prime \prime}$ & $80^{\circ} 21^{\prime} 39^{\prime \prime}$ & DBHYDRO \\
\hline S121_T & Stage $^{4}$ & $25^{\circ} 41^{\prime} 13^{\prime \prime}$ & $80^{\circ} 21^{\prime} 39^{\prime \prime}$ & DBHYDRO \\
\hline S123_T & Stage $^{4}$ & $25^{\circ} 36^{\prime} 37^{\prime \prime}$ & $80^{\circ} 18^{\prime} 28^{\prime \prime}$ & DBHYDRO \\
\hline S124_H & Stage $^{4}$ & $26^{\circ} 07^{\prime} 45^{\prime \prime}$ & $80^{\circ} 21^{\prime} 56^{\prime \prime}$ & DBHYDRO \\
\hline S124_T & Stage $^{4}$ & $26^{\circ} 07^{\prime} 45^{\prime \prime}$ & $80^{\circ} 21^{\prime} 56^{\prime \prime}$ & DBHYDRO \\
\hline S125_H & Stage $^{4}$ & $26^{\circ} 09^{\prime} 51^{\prime \prime}$ & $80^{\circ} 17^{\prime} 51^{\prime \prime}$ & DBHYDRO \\
\hline S125_T & Stage $^{4}$ & $26^{\circ} 09^{\prime} 51^{\prime \prime}$ & $80^{\circ} 17^{\prime} 51^{\prime \prime}$ & DBHYDRO \\
\hline S12A_H & Stage $^{4}$ & $25^{\circ} 45^{\prime} 42^{\prime \prime}$ & $80^{\circ} 49^{\prime} 17^{\prime \prime}$ & DBHYDRO \\
\hline S12A_T & Stage $^{4}$ & $25^{\circ} 45^{\prime} 42^{\prime \prime}$ & $80^{\circ} 49^{\prime} 17^{\prime \prime}$ & DBHYDRO \\
\hline S12B_H & Stage $^{4}$ & $25^{\circ} 45^{\prime} 42^{\prime \prime}$ & $80^{\circ} 46^{\prime} 11^{\prime \prime}$ & DBHYDRO \\
\hline S12B_T & Stage $^{4}$ & $25^{\circ} 45^{\prime} 42^{\prime \prime}$ & $80^{\circ} 46^{\prime} 11^{\prime \prime}$ & DBHYDRO \\
\hline $\mathrm{S} 12 \mathrm{C} \_\mathrm{T}$ & Stage $^{4}$ & $25^{\circ} 45^{\prime} 43^{\prime \prime}$ & $80^{\circ} 43^{\prime} 37^{\prime \prime}$ & DBHYDRO \\
\hline S12D_H & Stage $^{4}$ & $25^{\circ} 45^{\prime} 44^{\prime \prime}$ & $80^{\circ} 40^{\prime} 53^{\prime \prime}$ & DBHYDRO \\
\hline S12D_T & Stage $^{4}$ & $25^{\circ} 45^{\prime} 44^{\prime \prime}$ & $80^{\circ} 40^{\prime} 53^{\prime \prime}$ & DBHYDRO \\
\hline S13_H & Stage $^{4}$ & $26^{\circ} 03^{\prime} 58^{\prime \prime}$ & $80^{\circ} 12^{\prime} 31^{\prime \prime}$ & DBHYDRO \\
\hline S13_T & Stage $^{4}$ & $26^{\circ} 03^{\prime} 58^{\prime \prime}$ & $80^{\circ} 12^{\prime} 31^{\prime \prime}$ & DBHYDRO \\
\hline S13A_H & Stage $^{4}$ & $26^{\circ} 03^{\prime} 53^{\prime \prime}$ & $80^{\circ} 16^{\prime} 49^{\prime \prime}$ & DBHYDRO \\
\hline S13A_T & Stage $^{4}$ & $26^{\circ} 03^{\prime} 53^{\prime \prime}$ & $80^{\circ} 16^{\prime} 49^{\prime \prime}$ & DBHYDRO \\
\hline S13P_H & Stage $^{4}$ & $26^{\circ} 04^{\prime} 25^{\prime \prime}$ & $80^{\circ} 12^{\prime} 37^{\prime \prime}$ & DBHYDRO \\
\hline S13P_T & Stage $^{4}$ & $26^{\circ} 04^{\prime} 25^{\prime \prime}$ & $80^{\circ} 12^{\prime} 37^{\prime \prime}$ & DBHYDRO \\
\hline S140 SPW_H & Stage $^{4}$ & $26^{\circ} 10^{\prime} 19^{\prime \prime}$ & $80^{\circ} 49^{\prime} 38^{\prime \prime}$ & DBHYDRO \\
\hline S140 SPW_T & Stage $^{4}$ & $26^{\circ} 10^{\prime} 19^{\prime \prime}$ & $80^{\circ} 49^{\prime} 38^{\prime \prime}$ & DBHYDRO \\
\hline S140_H & Stage $^{4}$ & $26^{\circ} 10^{\prime} 19^{\prime \prime}$ & $80^{\circ} 49^{\prime} 38^{\prime \prime}$ & DBHYDRO \\
\hline S140_T & Stage $^{4}$ & $26^{\circ} 10^{\prime} 19^{\prime \prime}$ & $80^{\circ} 49^{\prime} 38^{\prime \prime}$ & DBHYDRO \\
\hline
\end{tabular}




\begin{tabular}{|c|c|c|c|c|}
\hline S142_H & Stage $^{4}$ & $26^{\circ} 09^{\prime} 36^{\prime \prime}$ & $80^{\circ} 26^{\prime} 46^{\prime \prime}$ & DBHYDRO \\
\hline $\mathrm{S} 142 \_\mathrm{T}$ & Stage $^{4}$ & $26^{\circ} 09^{\prime} 36^{\prime \prime}$ & $80^{\circ} 26^{\prime} 46^{\prime \prime}$ & DBHYDRO \\
\hline S143_T & Stage $^{4}$ & $26^{\circ} 10^{\prime} 34^{\prime \prime}$ & $80^{\circ} 26^{\prime} 51^{\prime \prime}$ & DBHYDRO \\
\hline S144_H & Stage $^{4}$ & $26^{\circ} 13^{\prime} 05^{\prime \prime}$ & $80^{\circ} 23^{\prime} 52^{\prime \prime}$ & DBHYDRO \\
\hline S144_T & Stage $^{4}$ & $26^{\circ} 13^{\prime} 05^{\prime \prime}$ & $80^{\circ} 23^{\prime} 52^{\prime \prime}$ & DBHYDRO \\
\hline S145_H & Stage $^{4}$ & $26^{\circ} 13^{\prime} 18^{\prime \prime}$ & $80^{\circ} 21^{\prime} 57^{\prime \prime}$ & DBHYDRO \\
\hline S145_T & Stage $^{4}$ & $26^{\circ} 13^{\prime} 18^{\prime \prime}$ & $80^{\circ} 21^{\prime} 57^{\prime \prime}$ & DBHYDRO \\
\hline S146_H & Stage $^{4}$ & $26^{\circ} 13^{\prime} 31^{\prime \prime}$ & $80^{\circ} 20^{\prime} 00^{\prime \prime}$ & DBHYDRO \\
\hline S146_T & Stage $^{4}$ & $26^{\circ} 13^{\prime} 31^{\prime \prime}$ & $80^{\circ} 20^{\prime} 00^{\prime \prime}$ & DBHYDRO \\
\hline S148_T & Stage $^{4}$ & $25^{\circ} 34^{\prime} 12^{\prime \prime}$ & $80^{\circ} 22^{\prime} 58^{\prime \prime}$ & DBHYDRO \\
\hline S166_H & Stage 4 & $25^{\circ} 31^{\prime} 06^{\prime \prime}$ & $80^{\circ} 25^{\prime} 56^{\prime \prime}$ & DBHYDRO \\
\hline S174_T & Stage $^{4}$ & $25^{\circ} 29^{\prime} 01^{\prime \prime}$ & $80^{\circ} 33^{\prime} 48^{\prime \prime}$ & DBHYDRO \\
\hline S175_H & Stage $^{4}$ & $25^{\circ} 25^{\prime} 04^{\prime \prime}$ & $80^{\circ} 34^{\prime} 25^{\prime \prime}$ & DBHYDRO \\
\hline S20_H & Stage $^{4}$ & $25^{\circ} 22^{\prime} 01^{\prime \prime}$ & $80^{\circ} 22^{\prime} 35^{\prime \prime}$ & DBHYDRO \\
\hline $\mathrm{S} 2 \mathrm{C}_{-} \mathrm{T}$ & Stage $^{4}$ & $25^{\circ} 22^{\prime} 01^{\prime \prime}$ & $80^{\circ} 22^{\prime} 35^{\prime \prime}$ & DBHYDRO \\
\hline S20G_T & Stage $^{4}$ & $25^{\circ} 29^{\prime} 21^{\prime \prime}$ & $80^{\circ} 20^{\prime} 50^{\prime \prime}$ & DBHYDRO \\
\hline $\mathrm{S} 21 \_\mathrm{T}$ & Stage $^{4}$ & $25^{\circ} 32^{\prime} 35^{\prime \prime}$ & $80^{\circ} 19^{\prime} 51^{\prime \prime}$ & DBHYDRO \\
\hline $\mathrm{S} 22_{-} \mathrm{T}$ & Stage $^{4}$ & $25^{\circ} 40^{\prime} 12^{\prime \prime}$ & $80^{\circ} 17^{\prime} 02^{\prime \prime}$ & DBHYDRO \\
\hline S27_T & Stage $^{4}$ & $25^{\circ} 50^{\prime} 55^{\prime \prime}$ & $80^{\circ} 11^{\prime} 20^{\prime \prime}$ & DBHYDRO \\
\hline S28_H & Stage $^{4}$ & $25^{\circ} 52^{\prime} 15^{\prime \prime}$ & $80^{\circ} 10^{\prime} 42^{\prime \prime}$ & DBHYDRO \\
\hline $\mathrm{S} 28 \_\mathrm{T}$ & Stage $^{4}$ & $25^{\circ} 52^{\prime} 15^{\prime \prime}$ & $80^{\circ} 10^{\prime} 42^{\prime \prime}$ & DBHYDRO \\
\hline S29_T & Stage $^{4}$ & $25^{\circ} 55^{\prime} 42^{\prime \prime}$ & $80^{\circ} 09^{\prime} 03^{\prime \prime}$ & DBHYDRO \\
\hline S30_H & Stage $^{4}$ & $25^{\circ} 57^{\prime} 24^{\prime \prime}$ & $80^{\circ} 25^{\prime} 53^{\prime \prime}$ & DBHYDRO \\
\hline S32_H & Stage $^{4}$ & $25^{\circ} 56^{\prime} 33^{\prime \prime}$ & $80^{\circ} 26^{\prime} 22^{\prime \prime}$ & DBHYDRO \\
\hline S33_H & Stage $^{4}$ & $26^{\circ} 08^{\prime} 08^{\prime \prime}$ & $80^{\circ} 11^{\prime} 27^{\prime \prime}$ & DBHYDRO \\
\hline S33_T & Stage $^{4}$ & $26^{\circ} 08^{\prime} 08^{\prime \prime}$ & $80^{\circ} 11^{\prime} 27^{\prime \prime}$ & DBHYDRO \\
\hline S332 & Stage $^{4}$ & $25^{\circ} 25^{\prime} 18^{\prime \prime}$ & $80^{\circ} 35^{\prime} 23^{\prime \prime}$ & DBHYDRO \\
\hline S334_T & Stage $^{4}$ & $25^{\circ} 45^{\prime} 42^{\prime \prime}$ & $80^{\circ} 30^{\prime} 08^{\prime \prime}$ & DBHYDRO \\
\hline S335_T & Stage $^{4}$ & $25^{\circ} 46^{\prime} 34^{\prime \prime}$ & $80^{\circ} 28^{\prime} 58^{\prime \prime}$ & DBHYDRO \\
\hline S336_T & Stage $^{4}$ & $25^{\circ} 45^{\prime} 41^{\prime \prime}$ & $80^{\circ} 29^{\prime} 48^{\prime \prime}$ & DBHYDRO \\
\hline
\end{tabular}




\begin{tabular}{|c|c|c|c|c|}
\hline Station name & Station type & Latitude & Longitude & Data source \\
\hline S337_H & Stage $^{4}$ & $25^{\circ} 56^{\prime} 32^{\prime \prime}$ & $80^{\circ} 26^{\prime} 27^{\prime \prime}$ & DBHYDRO \\
\hline S339_H & Stage $^{4}$ & $26^{\circ} 13^{\prime} 03^{\prime \prime}$ & $80^{\circ} 41^{\prime} 25^{\prime \prime}$ & DBHYDRO \\
\hline S339_T & Stage $^{4}$ & $26^{\circ} 13^{\prime} 03^{\prime \prime}$ & $80^{\circ} 41^{\prime} 25^{\prime \prime}$ & DBHYDRO \\
\hline S34_H & Stage $^{4}$ & $26^{\circ} 09^{\prime} 01^{\prime \prime}$ & $80^{\circ} 26^{\prime} 32^{\prime \prime}$ & DBHYDRO \\
\hline S34_T & Stage $^{4}$ & $26^{\circ} 09^{\prime} 01^{\prime \prime}$ & $80^{\circ} 26^{\prime} 32^{\prime \prime}$ & DBHYDRO \\
\hline S340_H & Stage $^{4}$ & $26^{\circ} 07^{\prime} 07^{\prime \prime}$ & $80^{\circ} 36^{\prime} 44^{\prime \prime}$ & DBHYDRO \\
\hline S343A_H & Stage $^{4}$ & $25^{\circ} 47^{\prime} 20^{\prime \prime}$ & $80^{\circ} 51^{\prime} 19^{\prime \prime}$ & DBHYDRO \\
\hline S343A_T & Stage $^{4}$ & $25^{\circ} 47^{\prime} 20^{\prime \prime}$ & $80^{\circ} 51^{\prime} 19^{\prime \prime}$ & DBHYDRO \\
\hline S343B_H & Stage $^{4}$ & $25^{\circ} 46^{\prime} 41^{\prime \prime}$ & $80^{\circ} 50^{\prime} 39^{\prime \prime}$ & DBHYDRO \\
\hline S343B_T & Stage $^{4}$ & $25^{\circ} 46^{\prime} 41^{\prime \prime}$ & $80^{\circ} 50^{\prime} 39^{\prime \prime}$ & DBHYDRO \\
\hline S344_H & Stage $^{4}$ & $25^{\circ} 55^{\prime} 08^{\prime \prime}$ & $80^{\circ} 50^{\prime} 11^{\prime \prime}$ & DBHYDRO \\
\hline S344_T & Stage $^{4}$ & $25^{\circ} 55^{\prime} 08^{\prime \prime}$ & $80^{\circ} 50^{\prime} 11^{\prime \prime}$ & DBHYDRO \\
\hline S36_H & Stage $^{4}$ & $26^{\circ} 10^{\prime} 24^{\prime \prime}$ & $80^{\circ} 10^{\prime} 42^{\prime \prime}$ & DBHYDRO \\
\hline S36_T & Stage $^{4}$ & $26^{\circ} 10^{\prime} 24^{\prime \prime}$ & $80^{\circ} 10^{\prime} 42^{\prime \prime}$ & DBHYDRO \\
\hline S37A_H & Stage $^{4}$ & $26^{\circ} 12^{\prime} 21^{\prime \prime}$ & $80^{\circ} 07^{\prime} 56^{\prime \prime}$ & DBHYDRO \\
\hline S37A_T & Stage $^{4}$ & $26^{\circ} 12^{\prime} 21^{\prime \prime}$ & $80^{\circ} 07^{\prime} 56^{\prime \prime}$ & DBHYDRO \\
\hline S37B_H & Stage $^{4}$ & $26^{\circ} 13^{\prime} 26^{\prime \prime}$ & $80^{\circ} 10^{\prime} 15^{\prime \prime}$ & DBHYDRO \\
\hline S37B_T & Stage $^{4}$ & $26^{\circ} 13^{\prime} 26^{\prime \prime}$ & $80^{\circ} 10^{\prime} 15^{\prime \prime}$ & DBHYDRO \\
\hline S38_H & Stage $^{4}$ & $26^{\circ} 13^{\prime} 47^{\prime \prime}$ & $80^{\circ} 17^{\prime} 54^{\prime \prime}$ & DBHYDRO \\
\hline S38_T & Stage $e^{4}$ & $26^{\circ} 13^{\prime} 47^{\prime \prime}$ & $80^{\circ} 17^{\prime} 54^{\prime \prime}$ & DBHYDRO \\
\hline S38A_H & Stage $^{4}$ & $26^{\circ} 13^{\prime} 49^{\prime \prime}$ & $80^{\circ} 17^{\prime} 52^{\prime \prime}$ & DBHYDRO \\
\hline S38C_H & Stage $^{4}$ & $26^{\circ} 13^{\prime} 44^{\prime \prime}$ & $80^{\circ} 17^{\prime} 52^{\prime \prime}$ & DBHYDRO \\
\hline S38C_T & Stage $^{4}$ & $26^{\circ} 13^{\prime} 44^{\prime \prime}$ & $80^{\circ} 17^{\prime} 52^{\prime \prime}$ & DBHYDRO \\
\hline S9_H & Stage $^{4}$ & $26^{\circ} 03^{\prime} 41^{\prime \prime}$ & $80^{\circ} 26^{\prime} 29^{\prime \prime}$ & DBHYDRO \\
\hline S9BFN & Stage $^{4}$ & $26^{\circ} 04^{\prime} 02^{\prime \prime}$ & $80^{\circ} 26^{\prime} 24^{\prime \prime}$ & DBHYDRO \\
\hline S9BFS & Stage $^{4}$ & $26^{\circ} 03^{\prime} 14^{\prime \prime}$ & $80^{\circ} 26^{\prime} 23^{\prime \prime}$ & DBHYDRO \\
\hline S9XN_H & Stage $^{4}$ & $26^{\circ} 03^{\prime} 43^{\prime \prime}$ & $80^{\circ} 26^{\prime} 35^{\prime \prime}$ & DBHYDRO \\
\hline SHARK.1_H & Stage $^{4}$ & $25^{\circ} 47^{\prime} 55^{\prime \prime}$ & $80^{\circ} 34^{\prime} 42^{\prime \prime}$ & DBHYDRO \\
\hline SNAPPERN & Stage $^{4}$ & $25^{\circ} 50^{\prime} 53^{\prime \prime}$ & $80^{\circ} 23^{\prime} 02^{\prime \prime}$ & DBHYDRO \\
\hline SWEVER1 & Stage $^{4}$ & $25^{\circ} 19^{\prime} 47^{\prime \prime}$ & $80^{\circ} 25^{\prime} 47^{\prime \prime}$ & DBHYDRO \\
\hline
\end{tabular}




\section{Station name Station type Latitude Longitude Data source}

\begin{tabular}{|c|c|c|c|c|}
\hline SWEVER2A & Stage $^{4}$ & $25^{\circ} 19^{\prime} 07^{\prime \prime}$ & $80^{\circ} 28^{\prime} 33^{\prime \prime}$ & DBHYDRO \\
\hline SWEVER2B & Stage $^{4}$ & $25^{\circ} 18^{\prime} 56^{\prime \prime}$ & $80^{\circ} 28^{\prime} 33^{\prime \prime}$ & DBHYDRO \\
\hline SWEVER3 & Stage $^{4}$ & $25^{\circ} 20^{\prime} 44^{\prime \prime}$ & $80^{\circ} 39^{\prime} 23^{\prime \prime}$ & DBHYDRO \\
\hline SWEVER4 & Stage $^{4}$ & $25^{\circ} 20^{\prime} 37^{\prime \prime}$ & $80^{\circ} 32^{\prime} 42^{\prime \prime}$ & DBHYDRO \\
\hline SWEVER5A & Stage $^{4}$ & $25^{\circ} 17^{\prime} 17^{\prime \prime}$ & $80^{\circ} 34^{\prime} 20^{\prime \prime}$ & DBHYDRO \\
\hline SWEVER5B & Stage $^{4}$ & $25^{\circ} 17^{\prime} 25^{\prime \prime}$ & $80^{\circ} 34^{\prime} 13^{\prime \prime}$ & DBHYDRO \\
\hline TPTS & Stage $^{4}$ & $25^{\circ} 12^{\prime} 23^{\prime \prime}$ & $80^{\circ} 22^{\prime} 29^{\prime \prime}$ & DBHYDRO \\
\hline TROUT CR_B & Stage $^{4}$ & $25^{\circ} 12^{\prime} 55^{\prime \prime}$ & $80^{\circ} 32^{\prime} 01^{\prime \prime}$ & DBHYDRO \\
\hline G119_T & Stage $e^{4,5}$ & $25^{\circ} 45^{\prime} 42^{\prime \prime}$ & $80^{\circ} 28^{\prime} 37^{\prime \prime}$ & DBHYDRO \\
\hline G211_H & Stage $e^{4,5}$ & $25^{\circ} 39^{\prime} 31^{\prime \prime}$ & $80^{\circ} 29^{\prime} 52^{\prime \prime}$ & DBHYDRO \\
\hline G211_T & Stage $e^{4,5}$ & $25^{\circ} 39^{\prime} 31^{\prime \prime}$ & $80^{\circ} 29^{\prime} 52^{\prime \prime}$ & DBHYDRO \\
\hline G72_T & Stage $\mathrm{e}^{4,5}$ & $25^{\circ} 52^{\prime} 09^{\prime \prime}$ & $80^{\circ} 20^{\prime} 21^{\prime \prime}$ & DBHYDRO \\
\hline G93_H & Stage $e^{4,5}$ & $25^{\circ} 44^{\prime} 18^{\prime \prime}$ & $80^{\circ} 17^{\prime} 12^{\prime \prime}$ & DBHYDRO \\
\hline S118_H & Stage $e^{4,5}$ & $25^{\circ} 37^{\prime} 22^{\prime \prime}$ & $80^{\circ} 20^{\prime} 30^{\prime \prime}$ & DBHYDRO \\
\hline S118_T & Stage $e^{4,5}$ & $25^{\circ} 37^{\prime} 22^{\prime \prime}$ & $80^{\circ} 20^{\prime} 30^{\prime \prime}$ & DBHYDRO \\
\hline S119_H & Stage $e^{4,5}$ & $25^{\circ} 38^{\prime} 33^{\prime \prime}$ & $80^{\circ} 20^{\prime} 18^{\prime \prime}$ & DBHYDRO \\
\hline S119_T & Stage $e^{4,5}$ & $25^{\circ} 38^{\prime} 33^{\prime \prime}$ & $80^{\circ} 20^{\prime} 18^{\prime \prime}$ & DBHYDRO \\
\hline S120_T & Stage $e^{4,5}$ & $25^{\circ} 40^{\prime} 15^{\prime \prime}$ & $80^{\circ} 19^{\prime} 17^{\prime \prime}$ & DBHYDRO \\
\hline S122_H & Stage ${ }^{4,5}$ & $25^{\circ} 35^{\prime} 39^{\prime \prime}$ & $80^{\circ} 20^{\prime} 53^{\prime \prime}$ & DBHYDRO \\
\hline S122_T & Stage $^{4,5}$ & $25^{\circ} 35^{\prime} 39^{\prime \prime}$ & $80^{\circ} 20^{\prime} 53^{\prime \prime}$ & DBHYDRO \\
\hline S123_H & Stage $e^{4,5}$ & $25^{\circ} 36^{\prime} 37^{\prime \prime}$ & $80^{\circ} 18^{\prime} 28^{\prime \prime}$ & DBHYDRO \\
\hline S148_H & Stage $e^{4,5}$ & $25^{\circ} 34^{\prime} 12^{\prime \prime}$ & $80^{\circ} 22^{\prime} 58^{\prime \prime}$ & DBHYDRO \\
\hline S149_H & Stage $e^{4,5}$ & $25^{\circ} 35^{\prime} 31^{\prime \prime}$ & $80^{\circ} 21^{\prime} 40^{\prime \prime}$ & DBHYDRO \\
\hline S151_H & Stage $e^{4,5}$ & $26^{\circ} 00^{\prime} 43^{\prime \prime}$ & $80^{\circ} 30^{\prime} 35^{\prime \prime}$ & DBHYDRO \\
\hline S151_T & Stage $e^{4,5}$ & $26^{\circ} 00^{\prime} 43^{\prime \prime}$ & $80^{\circ} 30^{\prime} 35^{\prime \prime}$ & DBHYDRO \\
\hline S165_H & Stage ${ }^{4,5}$ & $25^{\circ} 32^{\prime} 33^{\prime \prime}$ & $80^{\circ} 24^{\prime} 34^{\prime \prime}$ & DBHYDRO \\
\hline S165_T & Stage $e^{4,5}$ & $25^{\circ} 32^{\prime} 33^{\prime \prime}$ & $80^{\circ} 24^{\prime} 34^{\prime \prime}$ & DBHYDRO \\
\hline S166_T & Stage $e^{4,5}$ & $25^{\circ} 31^{\prime} 06^{\prime \prime}$ & $80^{\circ} 25^{\prime} 56^{\prime \prime}$ & DBHYDRO \\
\hline S167_H & Stage $e^{4,5}$ & $25^{\circ} 30^{\prime} 09^{\prime \prime}$ & $80^{\circ} 27^{\prime} 48^{\prime \prime}$ & DBHYDRO \\
\hline S167_T & Stage $e^{4,5}$ & $25^{\circ} 30^{\prime} 09^{\prime \prime}$ & $80^{\circ} 27^{\prime} 48^{\prime \prime}$ & DBHYDRO \\
\hline
\end{tabular}




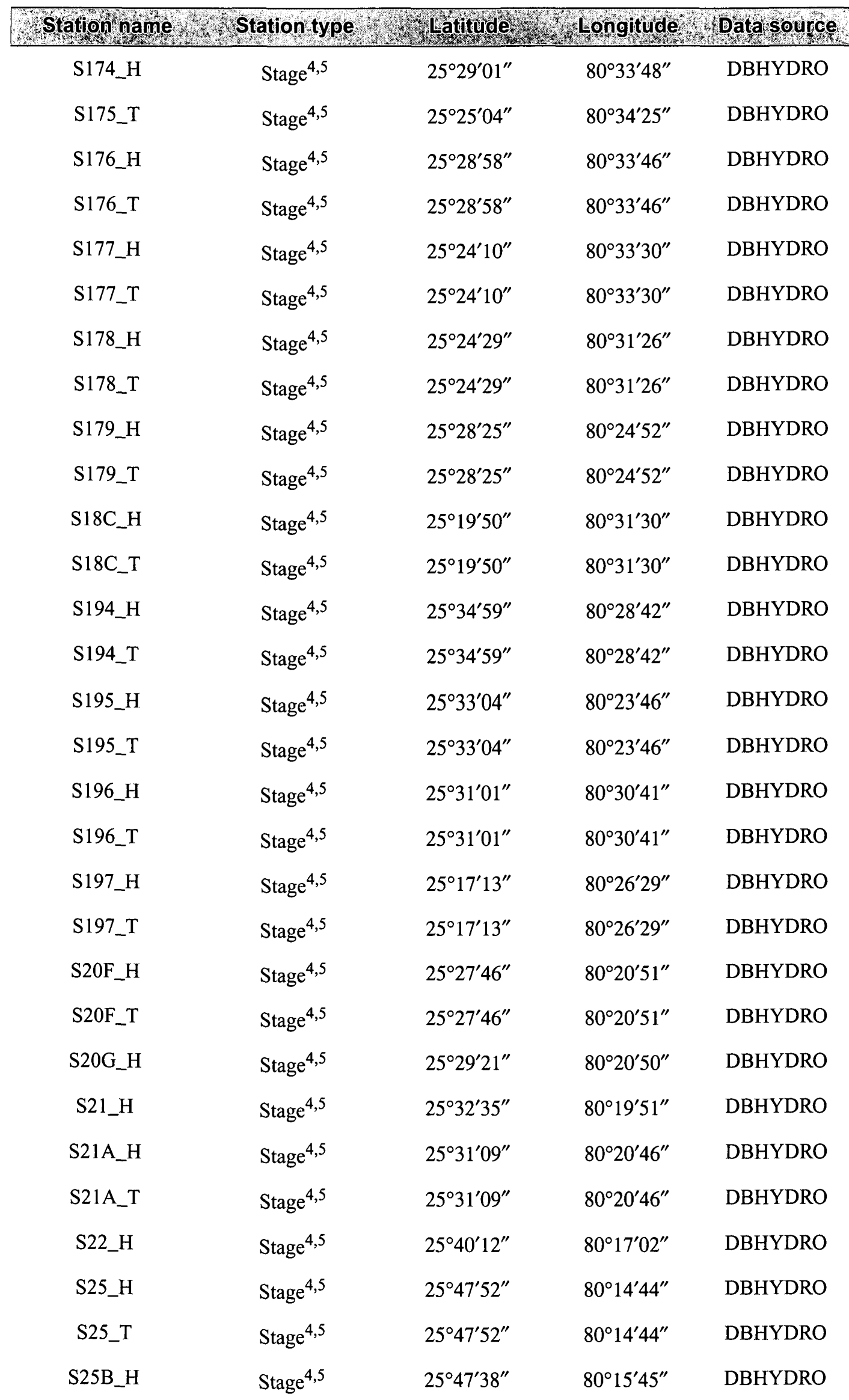




\section{Station name}

Station type

Látitude

Longitude

Data source

S25B_T

Stage ${ }^{4}$,

$25^{\circ} 47^{\prime} 38^{\prime \prime}$

$80^{\circ} 15^{\prime} 45^{\prime \prime}$

DBHYDRO

S26_H

Stage $e^{4,5}$

$25^{\circ} 48^{\prime} 29^{\prime \prime}$

$80^{\circ} 15^{\prime} 39^{\prime \prime}$

DBHYDRO

S26_T

Stage 4,5

$25^{\circ} 48^{\prime} 29^{\prime \prime}$

$80^{\circ} 15^{\prime} 39^{\prime \prime}$

DBHYDRO

S27_H

Stage $e^{4,5}$

$25^{\circ} 50^{\prime} 55^{\prime \prime}$

$80^{\circ} 11^{\prime} 20^{\prime \prime}$

DBHYDRO

S29_H

Stage $e^{4,5}$

$25^{\circ} 55^{\prime} 42^{\prime \prime}$

$80^{\circ} 09^{\prime} 03^{\prime \prime}$

DBHYDRO

S30_T

Stage $e^{4,5}$

$25^{\circ} 57^{\prime} 24^{\prime \prime}$

$80^{\circ} 25^{\prime} 53^{\prime \prime}$

DBHYDRO

S31_H

Stage $e^{4,5}$

$25^{\circ} 56^{\prime} 34^{\prime \prime}$

$80^{\circ} 26^{\prime} 25^{\prime \prime}$

DBHYDRO

S31_T

Stage 4,5

$25^{\circ} 56^{\prime} 34^{\prime \prime}$

$80^{\circ} 26^{\prime} 25^{\prime \prime}$

DBHYDRO

S331_H

Stage 4,5

$25^{\circ} 36^{\prime} 39^{\prime \prime}$

$80^{\circ} 30^{\prime} 35^{\prime \prime}$

DBHYDRO

S331_T

Stage ${ }^{4,5}$

$25^{\circ} 36^{\prime} 39^{\prime \prime}$

$80^{\circ} 30^{\prime} 35^{\prime \prime}$

DBHYDRO

S332_H

Stage 4,5

S332_T

Stage $e^{4,5}$

$25^{\circ} 25^{\prime} 18^{\prime \prime}$

$80^{\circ} 35^{\prime} 23^{\prime \prime}$

DBHYDRO

S333_H

Stage $e^{4,5}$

$25^{\circ} 25^{\prime} 18^{\prime \prime}$

$80^{\circ} 35^{\prime} 23^{\prime \prime}$

DBHYDRO

S333_T

Stage $e^{4,5}$

$25^{\circ} 45^{\prime} 43^{\prime \prime}$

$80^{\circ} 40^{\prime} 27^{\prime \prime}$

DBHYDRO

S334_H

Stage $e^{4,5}$

$25^{\circ} 45^{\prime} 43^{\prime \prime}$

$80^{\circ} 40^{\prime} 27^{\prime \prime}$

DBHYDRO

S335_H

Stage 4,5

$25^{\circ} 45^{\prime} 42^{\prime \prime}$

$80^{\circ} 30^{\prime} 08^{\prime \prime}$

DBHYDRO

$25^{\circ} 46^{\prime} 34^{\prime \prime}$

$80^{\circ} 28^{\prime} 58^{\prime \prime}$

DBHYDRO

S336_H

Stage $e^{4,5}$

$25^{\circ} 45^{\prime} 41^{\prime \prime}$

$80^{\circ} 29^{\prime} 48^{\prime \prime}$

DBHYDRO

S337_T

Stage $e^{4,5}$

S338_H

Stage $e^{4,5}$

$25^{\circ} 56^{\prime} 32^{\prime \prime}$

$80^{\circ} 26^{\prime} 27^{\prime \prime}$

DBHYDRO

S338_T

Stage $e^{4,5}$

S340_T

Stage 4,5

$25^{\circ} 39^{\prime} 38^{\prime \prime}$

$80^{\circ} 28^{\prime} 49^{\prime \prime}$

DBHYDRO

$25^{\circ} 39^{\prime} 38^{\prime \prime}$

$80^{\circ} 28^{\prime} 49^{\prime \prime}$

DBHYDRO

S9_T

Stage $e^{4,5}$

$26^{\circ} 07^{\prime} 07^{\prime \prime}$

$80^{\circ} 36^{\prime} 44^{\prime \prime}$

DBHYDRO

G72_C

Flow $^{6}$

$26^{\circ} 03^{\prime} 41^{\prime \prime}$

$80^{\circ} 26^{\prime} 29^{\prime \prime}$

DBHYDRO

G93

Flow ${ }^{6}$

$25^{\circ} 52^{\prime} 09^{\prime \prime}$

$80^{\circ} 20^{\prime} 21^{\prime \prime}$

DBHYDRO

S122_C

Flow $^{6}$

$25^{\circ} 44^{\prime} 18^{\prime \prime}$

$80^{\circ} 17^{\prime} 12^{\prime \prime}$

DBHYDRO

S123_S

Flow 6

$25^{\circ} 35^{\prime} 39^{\prime \prime}$

$80^{\circ} 20^{\prime} 53^{\prime \prime}$

DBHYDRO

S173_C

Flow ${ }^{6}$

$25^{\circ} 36^{\prime} 37^{\prime \prime}$

$80^{\circ} 18^{\prime} 28^{\prime \prime}$

DBHYDRO

S174_S

Flow 6

$25^{\circ} 36^{\prime} 39^{\prime \prime}$

$80^{\circ} 30^{\prime} 35^{\prime \prime}$

DBHYDRO

S194_C

Flow 6

$25^{\circ} 29^{\prime} 01^{\prime \prime}$

$80^{\circ} 33^{\prime} 48^{\prime \prime}$

DBHYDRO

S196_C

Flow 6

$25^{\circ} 34^{\prime} 59^{\prime \prime}$

$80^{\circ} 28^{\prime} 42^{\prime \prime}$

DBHYDRO

$25^{\circ} 31^{\prime} 01^{\prime \prime}$

$80^{\circ} 30^{\prime} 41^{\prime \prime}$

DBHYDRO 


\begin{tabular}{ccccc}
\hline Station name & Station type & Latitude & Longitude & Data source \\
\hline S196_C & Flow $^{6}$ & $25^{\circ} 31^{\prime} 01^{\prime \prime}$ & $80^{\circ} 30^{\prime} 41^{\prime \prime}$ & DBHYDRO \\
S197_C & Flow $^{6}$ & $25^{\circ} 17^{\prime} 13^{\prime \prime}$ & $80^{\circ} 26^{\prime} 29^{\prime \prime}$ & DBHYDRO \\
S20F_S & Flow $^{6}$ & $25^{\circ} 27^{\prime} 46^{\prime \prime}$ & $80^{\circ} 20^{\prime} 51^{\prime \prime}$ & DBHYDRO \\
S21_S & Flow $^{6}$ & $25^{\circ} 32^{\prime} 35^{\prime \prime}$ & $80^{\circ} 19^{\prime} 51^{\prime \prime}$ & DBHYDRO \\
S21A_S & Flow $^{6}$ & $25^{\circ} 31^{\prime} 09^{\prime \prime}$ & $80^{\circ} 20^{\prime} 46^{\prime \prime}$ & DBHYDRO \\
S22_S & Flow $^{6}$ & $25^{\circ} 40^{\prime} 12^{\prime \prime}$ & $80^{\circ} 17^{\prime} 02^{\prime \prime}$ & DBHYDRO \\
S25_C & Flow $^{6}$ & $25^{\circ} 47^{\prime} 52^{\prime \prime}$ & $80^{\circ} 14^{\prime} 44^{\prime \prime}$ & DBHYDRO \\
S25B_S & Flow $^{6}$ & $25^{\circ} 47^{\prime} 38^{\prime \prime}$ & $80^{\circ} 15^{\prime} 45^{\prime \prime}$ & DBHYDRO \\
S26_S & Flow $^{6}$ & $25^{\circ} 48^{\prime} 29^{\prime \prime}$ & $80^{\circ} 15^{\prime} 39^{\prime \prime}$ & DBHYDRO \\
S27_S & Flow $^{6}$ & $25^{\circ} 50^{\prime} 55^{\prime \prime}$ & $80^{\circ} 11^{\prime} 20^{\prime \prime}$ & DBHYDRO \\
S28_S & Flow $^{6}$ & $25^{\circ} 52^{\prime} 15^{\prime \prime}$ & $80^{\circ} 10^{\prime} 42^{\prime \prime}$ & DBHYDRO \\
S29_S & Flow $^{6}$ & $25^{\circ} 55^{\prime} 42^{\prime \prime}$ & $80^{\circ} 09^{\prime} 03^{\prime \prime}$ & DBHYDRO \\
S31_C & Flow $^{6}$ & $25^{\circ} 56^{\prime} 34^{\prime \prime}$ & $80^{\circ} 26^{\prime} 25^{\prime \prime}$ & DBHYDRO \\
S32_C & Flow $^{6}$ & $25^{\circ} 56^{\prime} 33^{\prime \prime}$ & $80^{\circ} 26^{\prime} 22^{\prime \prime}$ & DBHYDRO \\
S331_P & Flow $^{6}$ & $25^{\circ} 36^{\prime} 39^{\prime \prime}$ & $80^{\circ} 30^{\prime} 35^{\prime \prime}$ & DBHYDRO \\
S338_C & Flow $^{6}$ & $25^{\circ} 39^{\prime} 38^{\prime \prime}$ & $80^{\circ} 28^{\prime} 49^{\prime \prime}$ & DBHYDRO \\
\hline
\end{tabular}

${ }^{1}$ Used for regional-scale model to calibrate ground-water heads.

${ }^{2}$ Included in the U.S. Geological Survey saltwater intrusion monitoring network.

${ }^{3}$ Used for regional-scale model to develop Recharge package.

${ }^{4}$ Used for regional-scale model to assign stage values for general-head boundaries.

${ }^{5}$ Used for regional-scale model to assign stage values for River package.

${ }^{6}$ Used for regional-scale model to calibrate ground-water baseflow to canals. 


\section{Appendix IV Verification of the SEAWAT Code}

The SEAWAT code is relatively new and has not been widely used and tested. For this reason and because the code was modified for this study, SEAWAT was verified by running four different problems and comparing the results to those from other variable-density codes. Voss and Souza (1987) suggest that new variable-density codes should be tested and verified by running four or five benchmark problems that vary in complexity. These benchmark problems are listed below with the reference that describes the problem:

- Box problems (Voss and Souza, 1987)

- Henry problem (Voss and Souza, 1987)

- Elder problem (Voss and Souza, 1987)

- HYDROCOIN problem (Konikow and others, 1997)

- Salt-lake problem (Simmons and others, 1999)

This appendix presents the development and results for four of the benchmark problems listed above. The salt-lake problem has not yet been simulated with SEAWAT.

For each of the four problems evaluated, the results from SEAWAT compare reasonably well with the results from other numerical codes. From these comparisons, SEAWAT was determined to be an acceptable code for simulating the variable-density component of ground-water flow. As discussed in the report, the SEAWAT code was also modified to include variable-density sources and sinks. These additional features seem to work properly in the code, but they have not yet been verified against the results from other codes because benchmark problems for these types of features do not currently exist.

\section{Box Problems}

The purpose of the box problems is to verify that fluid velocities are properly calculated by the simulation code. Although inconsistent approximations for velocity are more likely to occur with finiteelement models, the box problems also provide a good test for variable-density codes based on the finitedifference approximation. There are two different cases of the box problem (Voss and Souza, 1987). In the first case, the variable-density code is tested by simulating flow within a two-dimensional, vertical cross-sectional model with no-flow boundaries on all sides. The size of the model domain and values for hydraulic conductivity and porosity are not important. Dispersivity values should be set to a length similar in size to the length of a model cell, and the diffusion coefficient should be set to zero. The initial conditions within the box consist of a layer of freshwater overlying a layer of saltwater-a stable configuration for fluid density. When this model is run with steady-state conditions, the interface between freshwater and saltwater should remain in the same layer of the model.

For the second case of the box problem, the initial condition and dispersion parameters are the same as the first case, but horizontal flow is induced across the box by setting different hydrostatic pressure boundaries on the left and right sides of the model. If the code is programmed correctly, the interface between freshwater and saltwater should remain in the same layer of the model.

SEAWAT was tested with both cases of the box problem. In each case, the interface remained in the correct model layer. This indicates that the velocity approximation used by SEAWAT is probably valid. 


\section{Henry Problem}

Henry (1964) presented an analytical solution for a problem that is thought to represent fresh ground water flowing toward a seawater boundary. Because an analytical solution was available for the Henry problem, many numerical codes were evaluated and tested with the Henry solution. Segol (1993) showed, however, that the Henry solution was not exact because Henry (1964) eliminated, for computational reasons, mathematical terms from the solution that were thought to be insignificant. When Segol (1993) recalculated Henry's solution with the additional terms, the improved answer was slightly different from the original solution. With the new solution, Segol (1993) showed that numerical codes such as SUTRA (Voss, 1984) could reproduce the correct answer for the Henry problem.

The basic design of the Henry problem is shown in figure $\mathrm{A} 1$. The cross-sectional box is $2 \mathrm{~m}$ long by $1 \mathrm{~m}$ high by $1 \mathrm{~m}$ wide. A constant flux of fresh ground water is applied to the left boundary at a rate $\left(Q_{i n}\right)$ of $5.702 \mathrm{~m}^{3} / \mathrm{d}$ per meter with a concentration $\left(C_{i n}\right)$ equal to zero. A constant-head boundary is applied to the right side of the box to represent seawater hydrostatic conditions. The head value applied to the constant head cells is set equal to $1 \mathrm{~m}$ and then converted to freshwater head values that increase appropriately with depth. The upper and lower model boundaries represent no flow.

The Henry problem caused further confusion among the modeling community because researchers attempting to verify numerical codes calculated an erroneous value for molecular diffusion that did not correlate with the original value used by Henry (Voss and Souza, 1987). For this reason, some researchers consider there to be two cases of the Henry problem: one in which the value for molecular diffusion $\left(D_{m}\right)$ is $0.57024 \mathrm{~m}^{2} / \mathrm{d}$ and another with a $D_{m}$ value of $1.62925 \mathrm{~m}^{2} / \mathrm{d}$ (fig. A2).

The finite-difference model grid used to discretize the problem domain consists of 21 columns and 10 layers. Each cell, with the exception of the cells in column 21 , is 0.1 by $0.1 \mathrm{~m}$ in size. Cells in column 21 are $0.01-\mathrm{m}$ horizontal by $0.1-\mathrm{m}$ vertical. The narrow column of cells at the right side of the model was used to more precisely locate the seawater hydrostatic boundary at a distance of 2 meters.
The comparison between SEAWAT and SUTRA results (Segol, 1993) for the Henry problem are shown in figure A2. Contours of relative salinity are in good agreement for both cases, especially away from the right boundary. Discrepancies in contours of relative salinity between the two models at the right boundary are probably due to differences in the way finiteelement and finite-difference models locate and represent constant-head (or pressure) boundaries.

\section{Elder Problem}

The Elder problem was originally designed for heat flow (Elder, 1967), but Voss and Souza (1987) recast the problem as a variable-density ground-water problem in which fluid density is a function of salt concentration. The Elder problem is commonly used to verify variable-density ground-water codes. The geometry and boundary conditions for the problem are shown in figure A3. A constant-concentration boundary is specified for part of the upper boundary. During the simulation, salt from the constant-concentration boundary diffuses into the model domain and initiates complex vortices that redistribute salt mass throughout the model. A constant-concentration boundary with a value of zero is specified for the lowest layer in the model. Two outlet cells with constant-head values of zero are specified for the upper left and right boundaries. These constant-head cells allow salt to diffuse into the model by providing an outlet for fluid and salt mass.

The Elder problem was run with the SEAWAT code for a period of 20 years. Several different methods were used to solve the transport equation. The MOC and the implicit solver with a central-in-space weighting scheme provided solutions closest to those of SUTRA (Voss and Souza, 1987) and those of Elder (1967). Relative concentrations from SEAWAT are compared with results from SUTRA (Voss and Souza, 1987) and the original nondimensional results from Elder (1967) for six different times (fig. A4). For each time, there seems to be a good match between the results from SEAWAT and SUTRA (Voss and Souza, 1987) and those of Elder (1967). 


\section{HYDROCOIN Problem}

The purpose of the Hydrologic Code Intercomparison project (HYDROCOIN) was to evaluate the accuracy of selected ground-water modeling codes. One of the problems used for testing is referred to as the HYDROCOIN problem. The HYDROCOIN problem presented here is based on case 5 that was reevaluated by Konikow and others (1997). The general geometry and boundary conditions for the problem are shown in figure A5. A sloping pressure boundary is imposed across the top of the box that is surrounded on the sides and bottom by no-flow conditions. Along the base of the middle portion of the model, a constant concentration condition is applied to represent the top of a salt dome. As ground water flows along the bottom boundary, salt disperses into the system and collects in the lower right corner of the model domain.

The SEAWAT code was used to simulate the HYDROCOIN problem and uses the general design employed by Konikow and others (1997). Prior to simulating the HYDROCOIN problem, the SEAWAT code was slightly modified to use the equation of state for fluid density as used by Konikow and others (1997). The comparison between SEAWAT and MOCDENSE is shown in figure A6. In general, the relative concentrations simulated by the two codes are consistent with one another. There is a discrepancy toward the upper right part of the model domain. While SEAWAT tends to produce slightly higher concentrations in this region, the comparison between the two codes is considered acceptable.

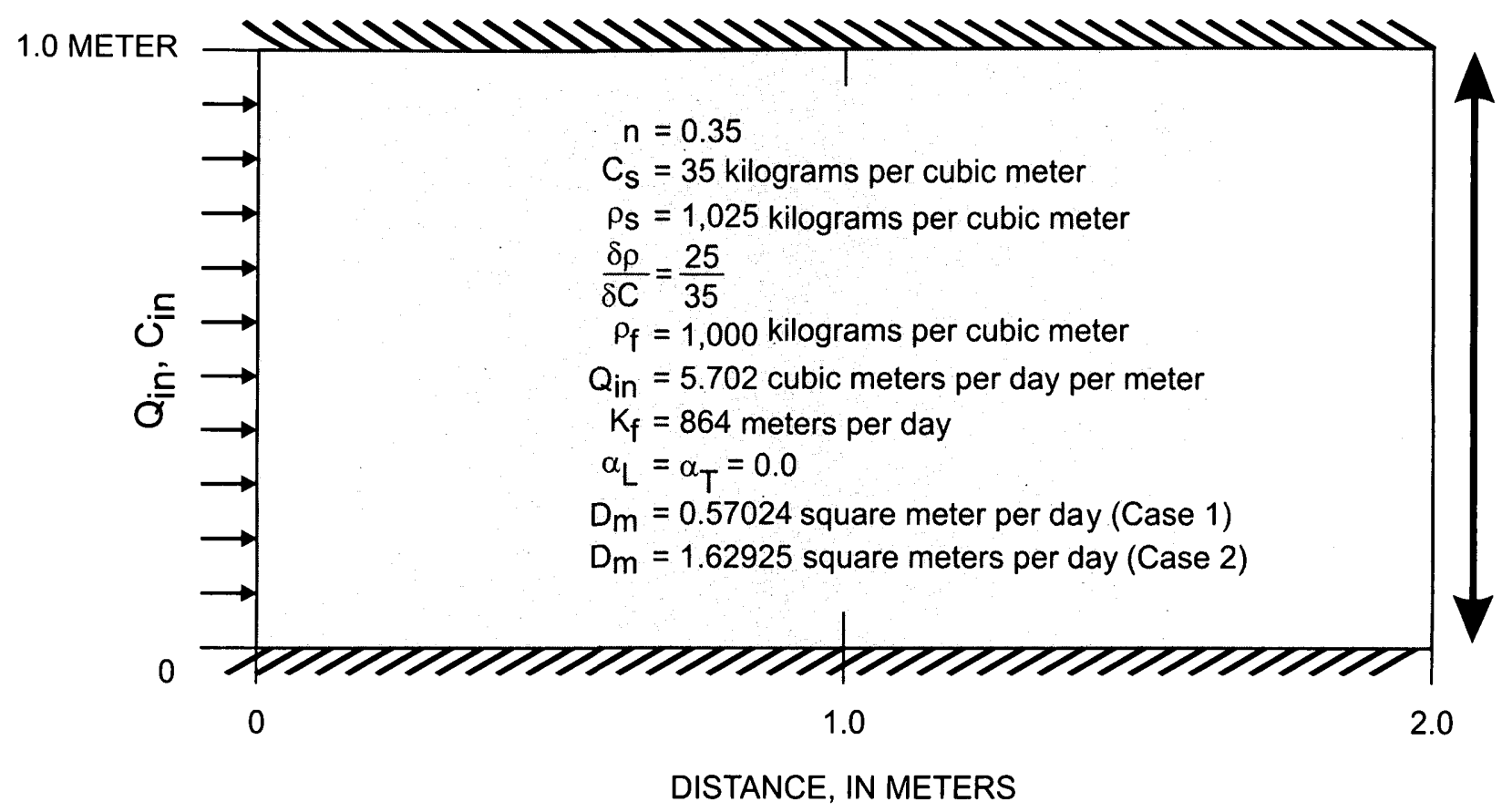

Figure A1. Boundary conditions and model parameters for the Henry problem. 

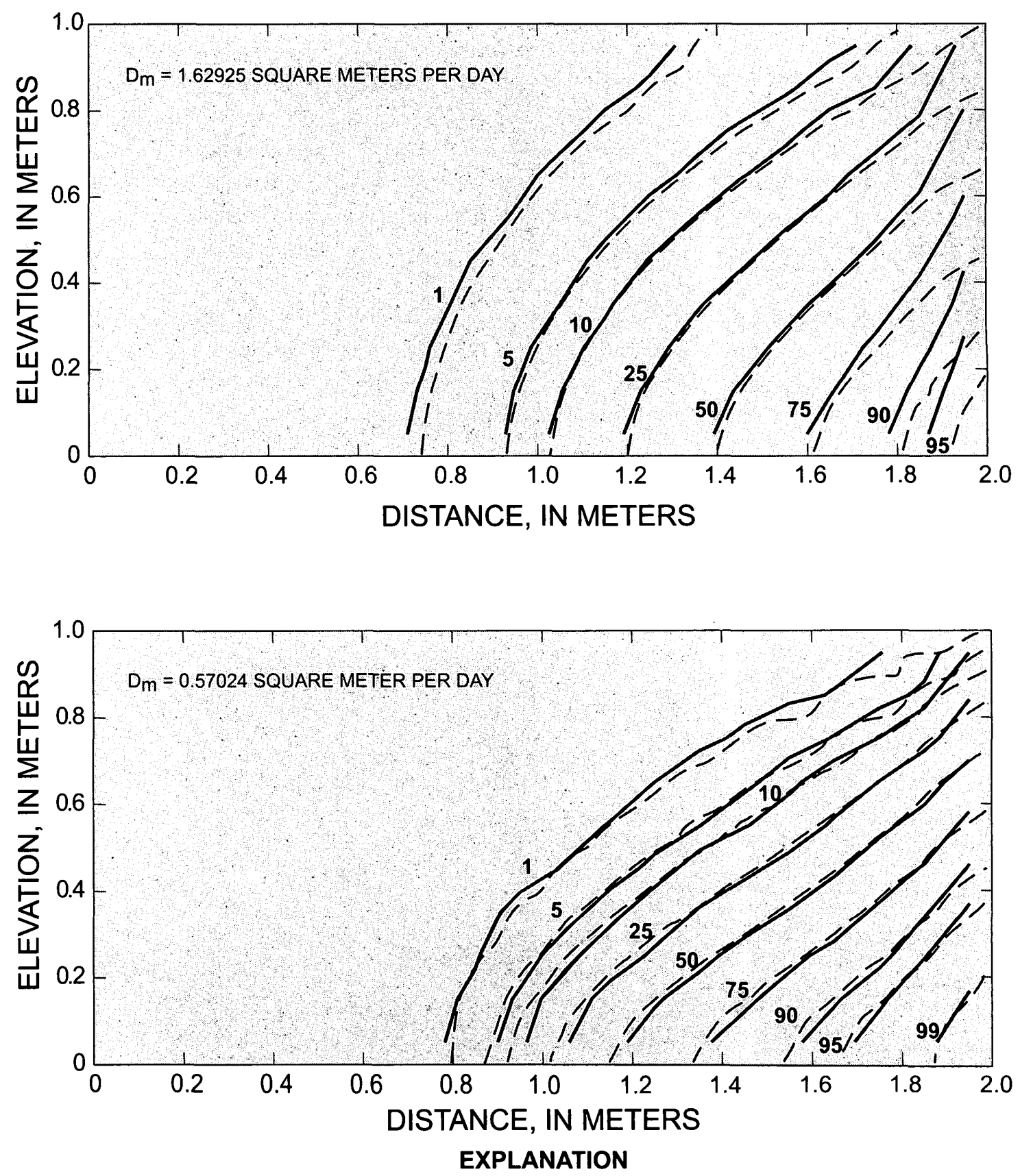

Relative concentration,

in percent

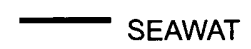

- - SUTRA (Segol, 1993)

Figure A2. Comparison between SEAWAT and SUTRA for the Henry problem. 


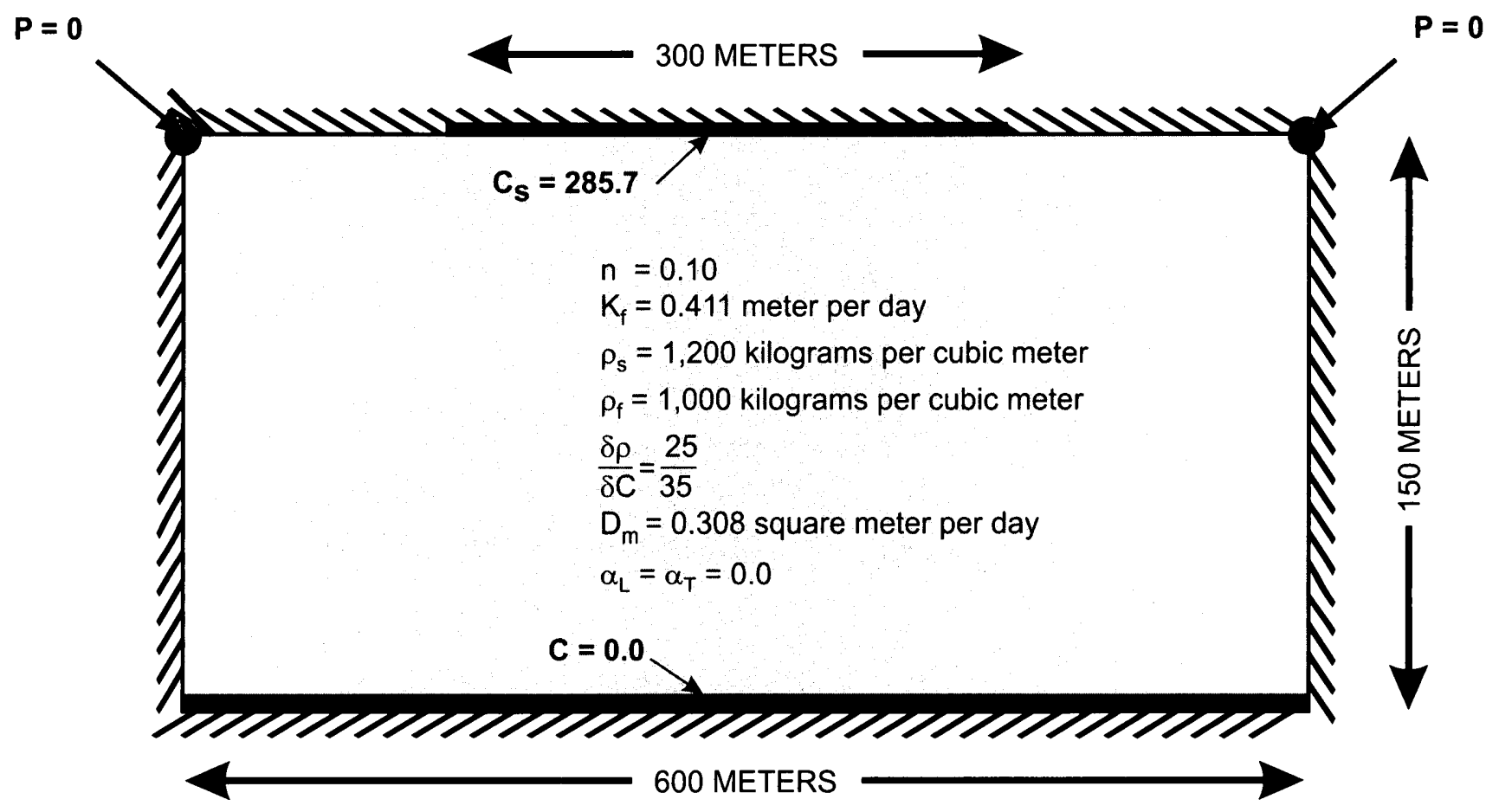

Figure A3. Boundary conditions and model parameters for the Elder problem. 

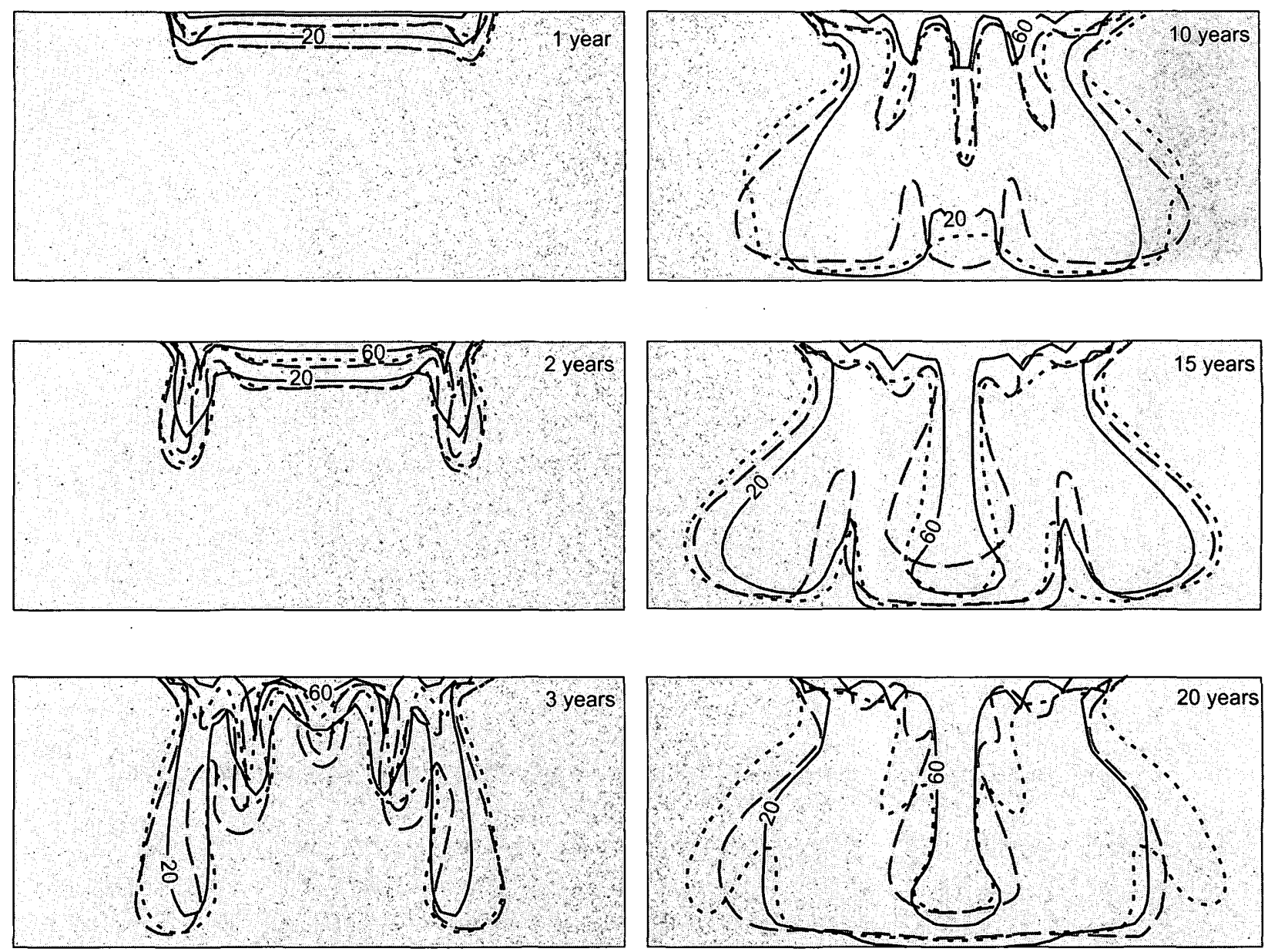

\section{EXPLANATION}

Relative concentration, in percent

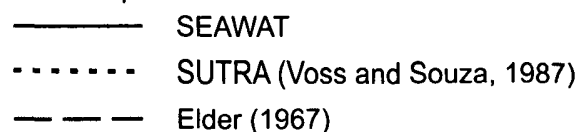

Figure A4. Comparison between SEAWAT, SUTRA and Elder's solution for the Elder problem. 


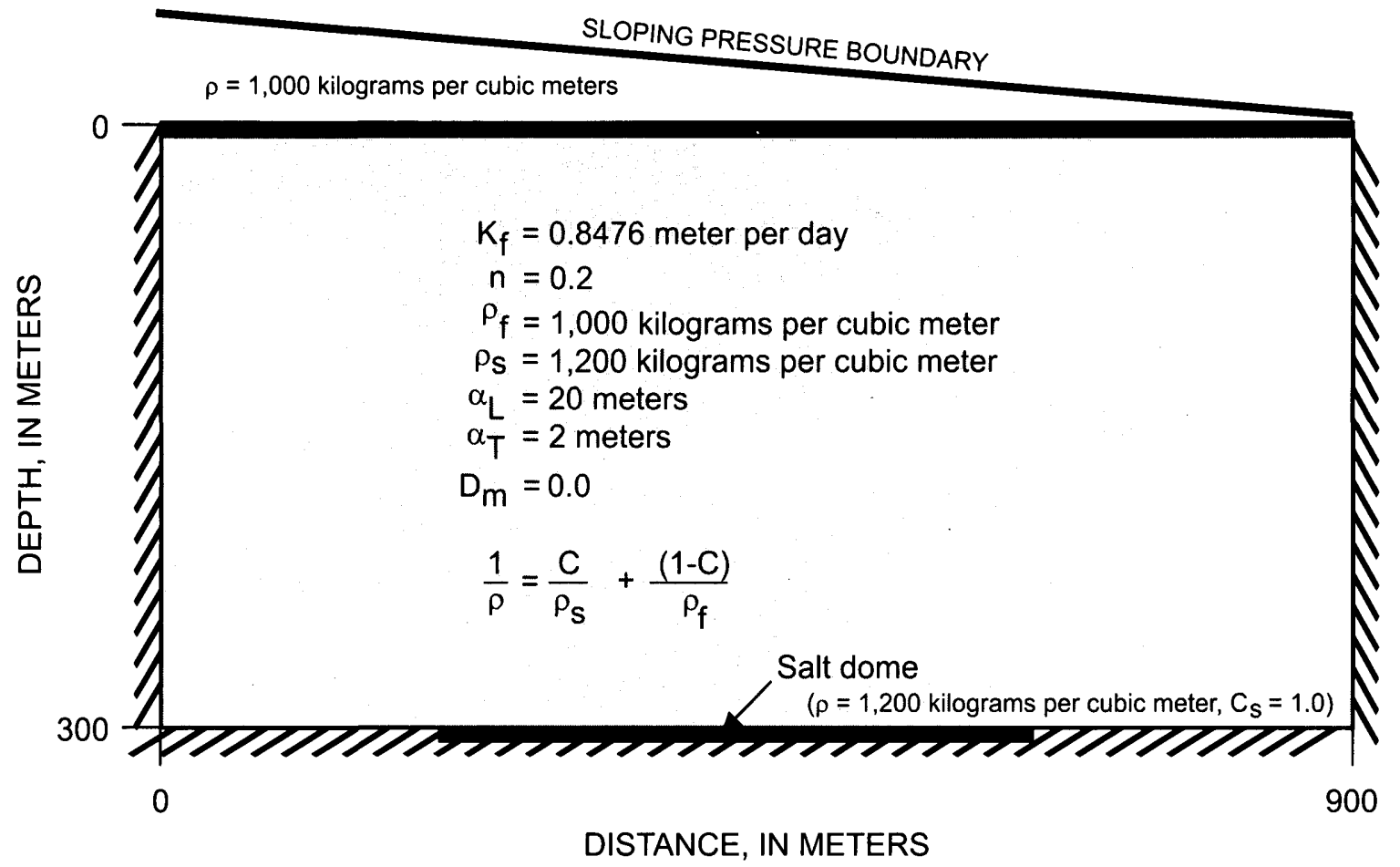

Figure A5. Boundary conditions and model parameters for the HYDROCOIN problem (from Konikow and others, 1997).

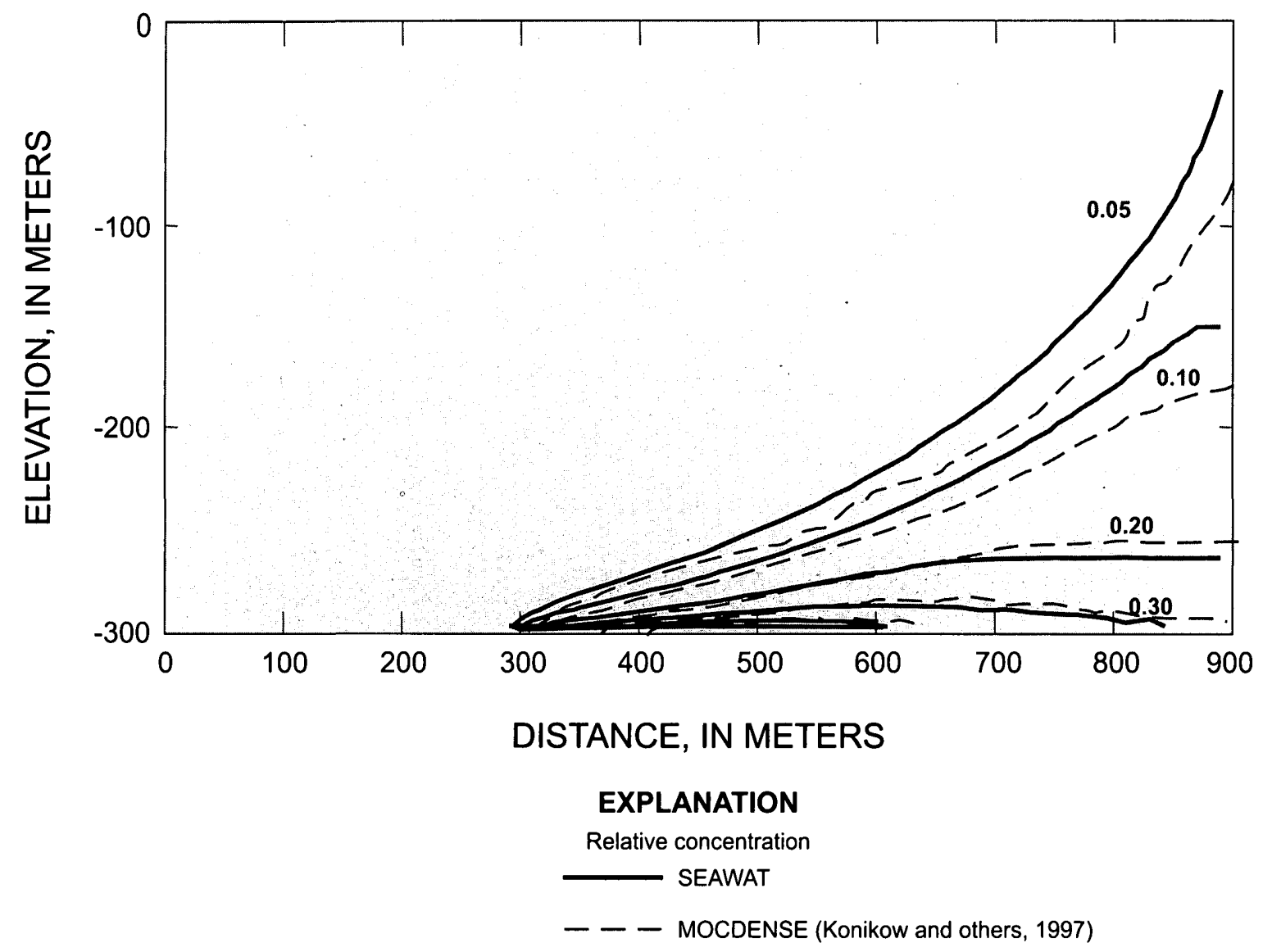

Figure A6. Comparison between SEAWAT and MOCDENSE for the HYDROCOIN problem. 
U.S. Department of the Interior U.S. Geological Survey 227 North Bronough Street Suite 3015

Tallahassee, FL 32301-1372 